UNIVERSIDADE DE SÃO PAULO

FACULDADE DE FILOSOFIA, LETRAS E CIÊNCIAS HUMANAS DEPARTAMENTO DE GEOGRAFIA

PROGRAMA DE PÓS-GRADUAÇÃO EM GEOGRAFIA HUMANA

JULIANA NAZARE LUQUEZ VIANA

\title{
RUPTURAS E CONTINUIDADES
}

A produção do espaço e o processo de reestruturação: um olhar a partir de São Gonçalo, Região Metropolitana do Rio de Janeiro 
JULIANA NAZARE LUQUEZ VIANA

\section{RUPTURAS E CONTINUIDADES}

A produção do espaço e o processo de reestruturação: um olhar a partir de São Gonçalo, Região Metropolitana do Rio de Janeiro

(Versão Corrigida)

Tese apresentada ao Programa de PósGraduação em Geografia Humana da Faculdade de Filosofia, Letras e Ciências Humanas da Universidade de São Paulo para obtenção do título de doutora.

Orientadora: Profa Dra Sandra Lencioni 
Autorizo a reprodução e divulgação total ou parcial deste trabalho, por qualquer meio convencional ou eletrônico, para fins de estudo e pesquisa, desde que citada a fonte.

Catalogação na Publicação Serviço de Biblioteca e Documentação

Faculdade de Filosofia, Letras e Ciências Humanas da Universidade de São Paulo

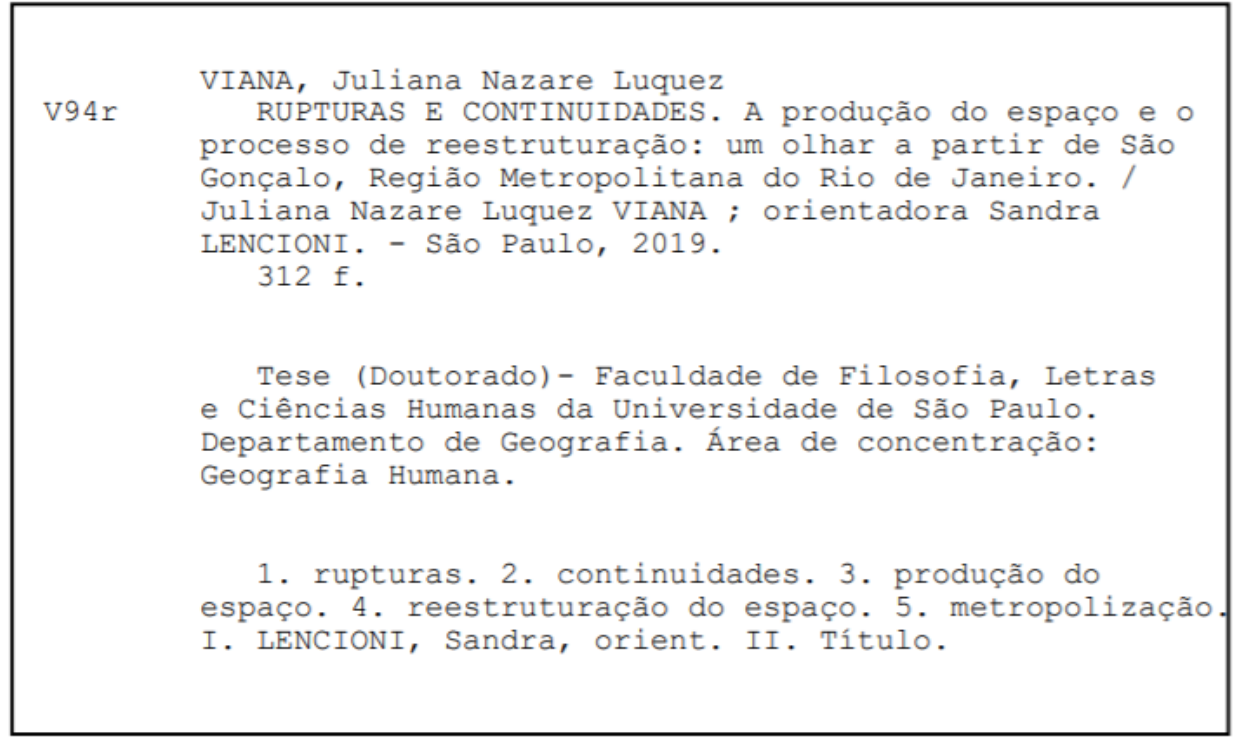




\title{
ENTREGA DO EXEMPLAR CORRIGIDO DA DISSERTAÇÃO/TESE Termo de Ciência e Concordância do (a) orientador (a)
}

\author{
Nome do (a) aluno (a): Juliana Nazaré Luquez Viana \\ Data da defesa: 17/12/2018 \\ Nome do Prof. (a) orientador (a): Sandra Lencioni
}

Nos termos da legislação vigente, declaro ESTAR CIENTE do conteúdo deste EXEMPLAR CORRIGIDO elaborado em atenção às sugestões dos membros da comissão Julgadora na sessão de defesa do trabalho, manifestando-me plenamente favorável ao seu encaminhamento e publicação no Portal Digital de Teses da USP.

São Paulo, 07/ 02 / 2019

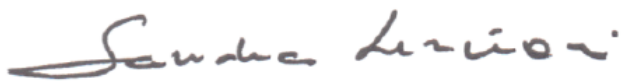


In memoriam de Nelson da Nóbrega Fernandes (1955-2014), professor do Departamento de Geografia da Universidade Federal Fluminense UFF/Niterói.

Aos 12.330.186 cidadãos metropolitanos do Rio de Janeiro, dos quais 1.038.081 urbanizam-se em São Gonçalo. 


\section{Banca Examinadora}

\section{Odette Carvalho de Lima Seabra}

Faculdade de Filosofia, Letras e Ciências Humanas

Universidade de São Paulo - USP

\section{Maria Beatriz Cruz Rufino}

Faculdade de Arquitetura e Urbanismo

Universidade de São Paulo - USP

\section{Regina Helena Tunes}

Instituto de Geografia

Universidade do Estado do Rio de Janeiro - UERJ 


\section{Agradecimentos}

Ao Sr. Inácio e à D. Vilma.

À Fábio Brito.

À Universidade de São Paulo pelo auxílio moradia desfrutado no CRUSP. À professora Sandra Lencioni.

Às professoras Odette Carvalho de Lima Seabra e Amélia Luisa Damiani.

Ao professor Paul Claval pela gentil recepção e pela grandeza de sua orientação no estágio doutoral no exterior.

À Fundação de Amparo à Pesquisa do Estado de São Paulo (FAPESP) pelo financiamento da pesquisa no Brasil (Bolsa no País - Processo $n^{0}$ 2015/13008-5) e pela Bolsa de Estágio de Pesquisa no Exterior (BEPE Processo no 2016/24074-1), este realizado no âmbito do Institut de Géographie da Université de Paris-Sorbonne IV.

Aos pesquisadores e as pesquisadoras vinculados ao Laboratório de Estudos Regionais em Geografia (LERGEO) do Departamento de Geografia da USP.

Àqueles, entre amigos, familiares, colegas e meros desconhecidos, cuja gratidão, foi manifestada pessoalmente. 
Brasil, meu nego

Deixa eu te contar

A história que a história não conta

$O$ avesso do mesmo lugar

Na luta é que a gente se encontra

Brasil, meu dengo

A Mangueira chegou

Com versos que o livro apagou

Desde 1500

Tem mais invasão do que descobrimento

Tem sangue retinto, pisado

Atrás do herói emoldurado

Mulheres, tamoios, mulatos

Eu quero um país que não está no retrato

Brasil, o teu nome é Dandara

Tua cara é de Cariri

Não veio do céu

Nem das mãos de Isabel

A liberdade é um Dragão no Mar de Aracati

Salve os caboclos de julho

Quem foi de aço nos anos de chumbo

Brasil, chegou a vez

De ouvir as Marias, Mahins, Marielles, Malês

Mangueira, tira a poeira dos porões

Ô, abre alas pros teus heróis de barracões

Dos brasis que se faz um país de Lecis, Jamelões

São verde e rosa as multidões

Samba Enredo da Estação Primeira de Mangueira para o Carnaval 2019

Composição: Deivid Domênico \& cia Intérpretes: Wantuir e Cacá Nascimento 


\section{RESUMO}

VIANA, Juliana Nazare Luquez. RUPTURAS E CONTINUIDADES. A produção do espaço e o processo de reestruturação: um olhar a partir de São Gonçalo, Região Metropolitana do Rio de Janeiro. 2019. 312 f. Tese (Doutorado em Geografia Humana) - Faculdade de Filosofia, Letras e Ciências Humanas, Universidade de São Paulo, São Paulo, 2019.

O presente trabalho busca analisar e discutir a produção do espaço a partir das fases do processo de reestruturação, suas rupturas e continuidades, tendo como situação concreta a realidade urbana de São Gonçalo (RJ). Admite-se que as transformações produzidas pelas dinâmicas dos processos espaciais provocam descontinuidades a partir das quais pode-se definir as fases de ruptura e conectar os elementos dissolvidos em cada um desses momentos buscando a identificação das continuidades, tomando-as como fundamento para uma perspectiva histórica da produção do espaço. Propomos uma periodização analítica da realidade urbana de São Gonçalo, construída a partir da identificação das rupturas e da caracterização das continuidades, reveladas pelo movimento de reestruturação do espaço. Nesse sentido, tal síntese desenvolveu-se segundo as seguintes problematizações: (a) quais as rupturas caracterizam cada fase do processo de reestruturação do espaço em São Gonçalo e (b) qual a relação dessas com a realidade metropolitana fluminense? Considerando, uma perspectiva histórica na análise da produção do espaço, (c) quais as continuidades encobertas em cada momento de ruptura? Em São Gonçalo, a dinâmica de produção do espaço, pôde ser compreendida segundo dois momentos determinantes, o urbano-industrial e o metropolitano-financeiro, e considerada em três fases de reestruturação: a urbanização que precede a industrialização e é capturada por ela; a urbanização espoliadora; e a urbanização especulativa (ou financeira) que impõe à problemática urbana análises e interpretações para além do dualismo centro-periferia no contexto da atual conformação da metrópole e de sua região.

Palavras-chave: rupturas, continuidades, produção do espaço, reestruturação do espaço, metropolização fluminense. 


\begin{abstract}
VIANA, Juliana Nazare Luquez. RUPTURES AND CONTINUITIES. The production of space and the process of restructuring: a look into São Gonçalo, Rio de Janeiro's metropolitan region. 2019. 312 f. Thesis (Doctorate in Geography) - Faculdade de Filosofia, Letras e Ciências Humanas, Universidade de São Paulo, São Paulo, 2019.
\end{abstract}

The present work intends to analyze and discuss the production of space resulting from a restructuring process and its phases, as well as its ruptures and continuities, taking as specific situation the urban reality of São Gonçalo (RJ). It is assumed that the transformations produced by the dynamics of the spatial processes lead to discontinuities from which one can define the phases of rupture and connect the dissolved elements in each of these moments aiming the identification of the continuities, taking them as a foundation for a historical perspective of the space production. We propose an analytical periodization of the urban reality of São Gonçalo, built from the identification of the ruptures and the characterization of the continuities, revealed by the space restructuring movement. In this sense, such a synthesis has developed according to the following problematizations: (a) what ruptures characterize each phase of the space restructuring process in São Gonçalo and (b) what is its relation with the Fluminense metropolitan reality? And, considering, a historical perspective in the analysis of space production, (c) what are the hidden continuities in each moment of rupture? In São Gonçalo, the dynamics of space production could be understood in two defining moments, the urban-industrial and the metropolitan-financial, and considered in three phases of restructuring: the urbanization that precedes industrialization and is captured by it; the spoiler urbanization; and the speculative (or financial) urbanization that imposes on the urban problematic analyzes and interpretations beyond the center-periphery dualism in the context of the current conformation of the metropolis and its region.

Keywords: ruptures, continuities, space production, space restructuring, fluminense metropolization 


\section{RÉSUMÉ}

VIANA, Juliana Nazare Luquez. RUPTURES ET CONTINUITÉS. La production d'espace et le processus de restructuration: un regard à partir de São Gonçalo, région métropolitaine de Rio de Janeiro. 2019. $312 \mathrm{f}$. Thèse (Doctorat en géographie humaine) - Faculdade de Filosofia, Letras e Ciências Humanas, Universidade de São Paulo, São Paulo, 2019.

Le travail, qui est désormais présenté, a comme but analyser et discuter la production de l'espace à partir des phases du processus de restructuration, de ses ruptures et de ses continuités, en prenant comme situation concrète la réalité urbaine de São Gonçalo (RJ). On suppose que les transformations produites par la dynamique des processus spatiaux provoquent des discontinuités à partir desquelles on peut définir les phases de rupture et connecter les éléments dissous à chacun de ces moments en cherchant l'identification des continuités, en s'appuyant sur une perspective production de l'espace. Nous proposons une périodisation analytique de la réalité urbaine de São Gonçalo, construite à partir de l'identification de ces ruptures et de la caractérisation des continuités, révélée par le mouvement de restructuration de l'espace. De cette façon, la synthèse développée selon les problématisations suivantes : (a) quelles ruptures caractérisent chaque phase du processus de restructuration de l'espace à São Gonçalo et (b) quelle est sa relation avec la réalité métropolitaine de Rio de Janeiro? Considérant une perspective historique dans l'analyse de la production spatiale, (c) quelles sont les continuités cachées dans chaque moment de rupture? A São Gonçalo, la dynamique de la production spatiale pourrait être appréhendée selon deux moments déterminants, I'urbain-industriel et le métropolitain-financier, et examinée dans trois phases de restructuration: I'urbanisation qui précède l'industrialisation et est capturée par elle ; I'urbanisation expropriante ; et l'urbanisation spéculative (ou financière) qui impose à la problématique urbaine des analyses et interprétations au-delà du dualisme centrepériphérie dans le contexte de la conformation actuelle de la métropole et de sa région.

Mots-clés: ruptures, continuités, production de l'espace, restructuration de l'espace, métropolisation dans l'agglomeration de Rio de Janeiro. 


\section{LISTA DE IMAGENS}

Imagem 1 - Vista do bairro Gradim, São Gonçalo. Ao fundo, o morro Corcovado

Imagem 2 - Unidade habitacional no bairro Itaúna, território dominado pelo Comando Vermelho ..........................

Imagem 3 - São Gonçalo: Ekos Monjolos Residencial, vendas para as faixas 1 e 1,5 do Programa Minha Casa Minha Vida. Localizado no bairro Monjolos, distante $21,4 \mathrm{~km}$ do centro da cidade; 24,1 de Niterói; 41,9 km do Rio de Janeiro (2018)

Imagem 4 - São Gonçalo: Residencial Bela Vista, vendas para as faixas 2 e 3 do Programa Minha Casa Minha Vida. Localizado no bairro operário Neves, distante $5,8 \mathrm{~km}$ do centro da cidade; 4,6 km de Niterói; $22,3 \mathrm{Km}$ do Rio de Janeiro (2018)

Imagem 5 - São Gonçalo: Residencial Imigrantes, vendas exclusivas para servidores das forças armadas e forças auxiliares. Localizado no bairro operário Vila Lage distante $4,3 \mathrm{~km}$ do centro da cidade; $7,1 \mathrm{~km}$ de Niterói; $24,8 \mathrm{~km}$ do Rio de Janeiro (2018)

Imagem 6 - São Gonçalo: empréstimo do Banco do Brasil ao Governo do Estado do Rio de Janeiro para projetos de mobilidade, infraestrutura urbana e grandes eventos (2012)

Imagem 7 - São Gonçalo: governador do Estado do Rio anuncia chamada para nova licitação para projeto da linha 3 do Metrô, desconsiderando projeto anterior (2012)

Imagem 8 - São Gonçalo: anúncio publicitário de empreendimento imobiliário próximo à futura linha 3 do Metrô (2011) .....

Imagem 9 - São Gonçalo: operação da intervenção militar em duas comunidades. Participaram da ação 4.300 militares das Forças Armadas, 120 policiais militares e 80 policiais civis. Trechos da Avenida Brasil (Rio de Janeiro), Ponte Rio-Niterói e Rodovia Niterói-Manilha (São Gonçalo) precisaram ser fechados para o deslocamento das tropas 
Imagem 10 - Operação policial com o apoio de tropas civis e militares no Complexo do Fazenda dos Mineiros, São Gonçalo: inibição ao tráfico de drogas e constrangimento à circulação dos moradores (set./2018)

Imagem 11 - Operação policial com o apoio de tropas civis e militares no Complexo do Fazenda dos Mineiros, São Gonçalo: inibição ao tráfico de drogas e constrangimento à circulação dos moradores (set./2018)

Imagem 12 - Vista da Ponte Rio-Niterói às margens da BR-101 em São Gonçalo, (2018)

Imagem 13 - São Gonçalo: localização dos três empreendimentos comerciais do tipo shopping center e da área onde será erguido o quarto, o Alcântara Plaza Shopping, com 210 lojas e $30.405 \mathrm{~m} 2$ (2018)

Imagem 14 - Parque industrial em São Gonçalo (1930)

Imagem 15 - Área de implantação do Condomínio Industrial e Empresarial de São Gonçalo (CIESG). Destaque para a concepção espacial do projeto apresentada no canto superior direito, conforme a BR Logística (2018)

Imagem 16 - Características da metropolização do espaço

Imagem 17 - São Gonçalo: síntese dos momentos da urbanização e das fases de reestruturação do espaço

Imagem 18 - Bairro Laranjal: antiga área de citricultura (década 1950)

Imagem 19 - Folder de lançamento do loteamento de Jardim Catarina (década 1950). O loteamento deu origem a um dos bairros mais populosos de São Gonçalo e consolidou-se na geografia histórica da urbanização de São Gonçalo como "área de risco" e de "bairro precário"

Imagem 20 - Instalações comerciais e de infraestrutura existentes no início do período de loteamentos do atual bairro Laranjal (1940-1950)

Imagem 21 - Instalações comerciais e de infraestrutura existentes no início do período de loteamentos do atual bairro Laranjal (1940-1950)

Imagem 22 - São Gonçalo, a Manchester fluminense: capa e editorial da Revista Vida Fluminense 
Imagem 23 - São Gonçalo, a Manchester fluminense: capa e editorial da Revista Vida Fluminense

Imagem 24 - Conserva Piracema: vestiário e refeitório da fábrica ainda em funcionamento, mas com reduzido número de operários

Imagem 25 - Conserva Piracema: salas administrativas, gestão e gerência de produção

Imagem 26 - Vista para o bairro de Alcântara. Em segundo plano, os edifícios destinados à moradia construídos na década de 1970

Imagem 27 - Praça Doutor Luiz Palmier, Centro (década de 1980) .... 202

Imagem 28 - Folder de lançamento imobiliário: primeiro apart hotel de São Gonçalo (2016) .................................. 206

Imagem 29 - Página da internet do apart hotel Dom Quixote (2018) .. 206

Imagem 30 - Shopping Pátio Alcântara (2016) ........................ 208

Imagem 31 - Praça Carlos Gianelli, área central de Alcântara (década 1970). O empreendimento Pátio Alcântara foi construído no lugar da antiga praça

Imagem 32 - Bairro Centro, empreendimento imobiliário de médio padrão e o Morro Menino Deus (2018)

Imagem 33 - Alguns aspectos e transformações socioespaciais da banlieue parisiense nas telas de pintores impressionistas

Imagem 34 - Localização de Saint-Denis na petite couronne da aglomeração urbana de Paris

Imagem 35 - Localização de São Gonçalo na aglomeração urbana institucionalizada do Rio de Janeiro

Imagem 36 - Saint-Denis: ao fundo, antiga chaminé de fábrica, um novo edifício e, em primeiro plano, a sinalização que indica o Estádio da França, construção símbolo da mais recente fase de reestruturação do espaço na aglomeração urbana de Paris

Imagem 37 - Saint-Denis: futura instalação da Gare Grand Paris Express

Imagem 38 - Clichy-Batignolles: área de planejamento combinada .... 


\section{LISTA DE GRÁFICOS}

Gráfico 1 - São Gonçalo: perfil socioeconômico dos respondentes identidade de gênero $(2018) \ldots \ldots \ldots \ldots \ldots \ldots \ldots \ldots \ldots \ldots . . . \ldots \ldots$

Gráfico 2 - São Gonçalo: perfil socioeconômico dos respondentes Portadores de Necessidades Especiais - PNE (2018) .... 88

Gráfico 3 - São Gonçalo: perfil socioeconômico dos respondentes (2018)

Gráfico 4 - São Gonçalo: problemas que afetam a vida na cidade (2018)

Gráfico 5 - São Gonçalo: urgências para a cidade (2018)

Gráfico 6 - São Gonçalo: transformações da cidade, segundo a percepção dos citadinos (2018)

Gráfico 7 - São Gonçalo: vivemos uma crise urbana? (2018)

Gráfico 8 - São Gonçalo: caminhos para buscar soluções à Crise Urbana (2018) 


\section{LISTA DE MAPAS}

Mapa 1 - Região Metropolitana do Rio de Janeiro: aglomeração e mancha urbanas (2018)

Mapa 2 - Rio de Janeiro: conformação e expansão da urbanização no em torno da Baía de Guanabara (2018)

Mapa 3 - Rio de Janeiro: ranking da receita per capita dos

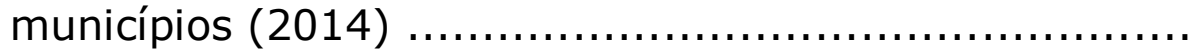

Mapa 4 - RMRJ: fluxos de deslocamentos para trabalho e estudo entre municípios (2018)

Mapa 5 - São Gonçalo: fluxos intra e interurbanos (2018) 106

Mapa 6 - São Gonçalo: zonas de estruturação urbana proposta pelo Plano Diretor (2009-2018) 


\section{LISTA DE QUADROS}

Quadro 1 - RMRJ: reestruturação setorizada do espaço (2018) ....... 59

Quadro 2 - Projetos que integram o Pró-Cidades (2012) .............. 100

Quadro 3 - Usos e sentidos do conceito de reestruturação na análise

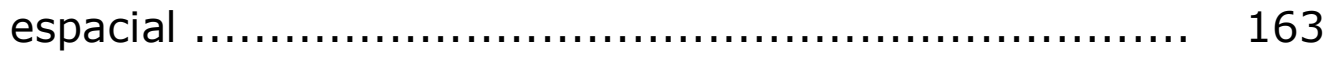

Quadro 4 - Eixos temáticos e acervos consultados em Paris e adjacências ............................................... 290

Quadro 5 - Reuniões de pesquisa realizadas na França ................ 296

Quadro 6 - Trabalhos de campo na aglomeração urbana de Paris .... 304 


\section{LISTA DE TABELAS}

Tabela 1 - Rio de Janeiro: Posição ocupada pelos maiores municípios*, em relação ao valor adicionado bruto dos Serviços e participações percentuais relativa e acumulada (2011) ..............................................

Tabela 2 - Aglomeração metropolitana fluminense: população e pessoal ocupado no comércio e na indústria (1950) ......

Tabela 3 - RMRJ: valor do m2 para compra de imóvel residencial considerando os municípios com maior dinâmica imobiliária (2015-2018)

Tabela 4 - Rio de Janeiro: municípios nas últimas posições do ranking de despesas com custeio per capita (2014) ......

Tabela 5 - Brasil: maiores fluxos de deslocamentos para trabalho e estudo (2015)

Tabela 6 - RMRJ: número de emprego formal por setor de atividade econômica e por município (2016)

Tabela 7 - São Gonçalo: tiroteios/disparos de arma de fogo (2018)

Tabela 8 - Rio de Janeiro: número de shoppings centers, por município (2018)

Tabela 9 - População residente no município de São Gonçalo (1940-1991)

Tabela 10 - Produto interno bruto total (bilhões), valor adicionado bruto da indústria e dos serviços (R\$1.000), Estado do Rio de Janeiro, Região Metropolitana do Rio de Janeiro (RMRJ) e alguns municípios metropolitanos (1999-2015) 


\section{LISTA DE ABREVIATURAS E SIGLAS}

ABESPetro

ABRASCE

APA

APA-Guapimirim

APL

BEMGE

BEPE

CEPERJ

CIESG

COMPERJ

ENEC

FAETEC

FAPESP

FGTS

Firjan

FUNDREM

IAU-ÎIfF

IBGE

II PND
Associação Brasileira das Empresas de Serviços de Petróleo

Associação Brasileira de Shopping Centers

Áreas de Proteção Ambiental

Área de Proteção Ambiental de Guapimirim

Arranjos Produtivos Locais

Banco do Estado de Minas Gerais

Bolsa de Estágio de Pesquisa no Exterior

Fundação Centro Estadual de Estatísticas, Pesquisas e Formação de Servidores Públicos do Rio de Janeiro

Condomínio Industrial e Empresarial de São Gonçalo

Complexo Petroquímico do Rio de Janeiro

Laboratório Espace, Nature et Culture.

Unidades da Fundação de Apoio à Escola Técnica do Estado do Rio de Janeiro

Fundação de Amparo à Pesquisa do Estado de São Paulo Fundo de Garantia do Tempo de Serviço

Federação das Indústrias do Rio de Janeiro

Fundação para o Desenvolvimento da Região Metropolitana do Rio de Janeiro

Institut d'aménagement et d'urbanisme de la Région d'île-de-France

Instituto Brasileiro de Geografia e Estatística

II Plano Nacional de Desenvolvimento 
PNE

PROMEF

RAIS/MTE

RJ

RMRJ

Secovi Rio

SPC

TCIs

UERJ/FFP

ZAC

ZAE

ZDI
Portadores de Necessidades Especiais

Programa de Modernização e Expansão da Frota

Relação Anual de Informações Sociais do Ministério do Trabalho e Emprego

Rio de Janeiro

Região Metropolitana do Rio de Janeiro

Sindicato da Habitação

Serviço de Proteção ao Crédito

Tecnologias de Informação

Universidade do Estado do Rio de Janeiro Campus São Gonçalo

Zones d'activités concertées

zones d'activités économiques

Zona de Dinamização 


\section{SUMÁRIO}

Introdução

Capítulo 1 Da crise urbana à problemática urbana do Rio de Janeiro: São Gonçalo como expressão da complexidade metropolitana ................................

1.1 Rio metropolitano: concentração e centralização, dispersão e fragmentação

1.1.1. "Crise urbana": advertência preambular

84

1.2 Um olhar a partir de São Gonçalo

Capítulo 2 Produção do espaço metropolitano fluminense: dinâmicas e processos na análise espacial

2.1 Referências analíticas para a discussão da produção do espaço e dos processos que a fundamentam ........

2.1.1 São Gonçalo: desenvolvimento industrial e periferização, aspectos para perceber o movimento ...

2.2 Reestruturação: processo e conceito para a análise espacial

2.2.1 Reestruturação: compreensão da produção do espaço e usos do conceito

2.2.2 Reestruturação: adjetivações, sentidos e perspectivas metodológicas

2.3 As fases do processo de reestruturação do espaço em São Gonçalo

2.3.1 O processo de estruturação do espaço em São Gonçalo

2.3.2 A urbanização de São Gonçalo no movimento da reestruturação do espaço 
Capítulo 3 Rupturas e continuidades: um ponto de vista sobre a problematização da realidade urbana ....

3.1 Transformações socioespaciais e princípios interpretativos: o léxico conceitual na compreensão da produção do espaço

3.1.1 Entre les banlieues, périphéries et périurbains parisiens: aspectos teóricos e conceituais na compreensão das transformações socioespaciais da aglomeração urbana de Paris

3.1.2 Olhares cruzados. As aglomerações urbanas Parisiense e Fluminense: um ponto de vista para a problematização da realidade urbana contemporânea

3.2 As tríades do movimento

Conclusão

Bibliografia

Apêndice do Capítulo 3 


"




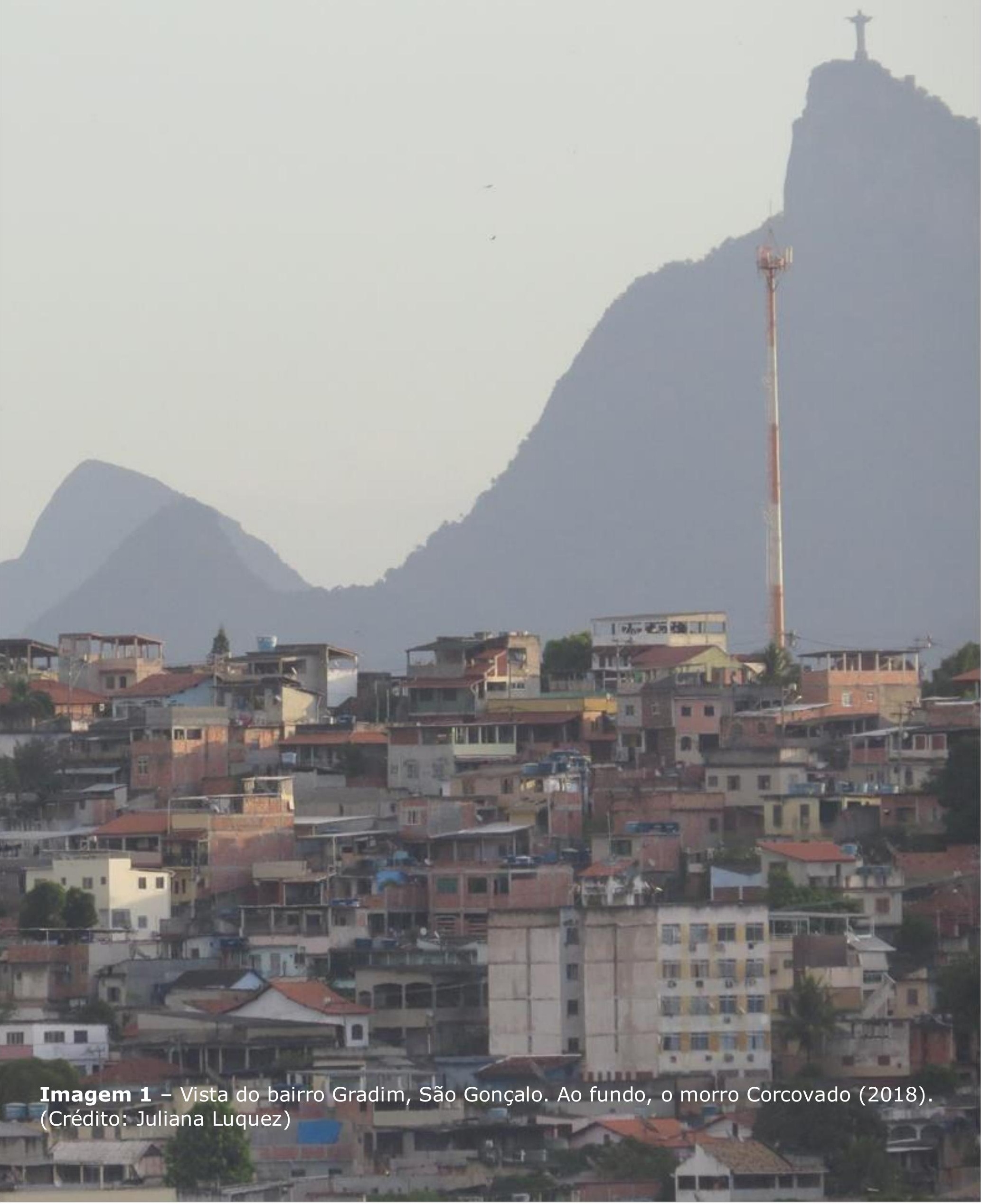


Ah, Redentor! Em seus braços você abrange todas as minhas preocupações. Eu aqui, todos os dias, pensando caminhos, juntando pistas e formulando respostas às questões que emanam do movimento que daí você, privilegiadamente, observa. Alto e estático, observa. Você parece não se misturar ao movimento, você parece ser a única coisa que não se movimenta. Lamento, Redentor, mas esse fato o coloca em desvantagem em relação a todos que se movem. Pois, imersos estamos em uma condição que você desconhece. Nossa vida se faz, se desfaz e se refaz enquanto movemos e somos movidos. E é a compreensão desse movimento que nos motiva, com esperança, a tomar outros rumos.

O caminho de problematização da realidade metropolitana fluminense que propomos é esse: um manifesto ao movimento. 0 movimento não só da realidade, mas também da maneira como a compreendemos. O movimento do real que se apreenda no pensamento sobre a análise concreta; aquele como historicidade, este como síntese metodológica.

Nas palavras de Lefebvre

O inteligível definia-se pela continuidade. [...] Propõe-se então uma nova figura de inteligibilidade: corte $e$ montagem. Desconstruir e reconstruir, assim se define a operação que torna inteligível 0 real. Às transições substituem os cortes; ao devir, a estabilidade e o equilíbrio; às continuidades, as estruturas e configurações descontínuas. (LEFEBVRE, 1971, p. 17-18).

Essa inteligibilidade (crítica) nos permite penetrar no movimento da realidade apreendida e transcender os limites e paradoxos das dicotomias interpretativas. Como, então, conduzir a análise a partir desse "corte e montagem" da inteligibilidade sem nos perder em excessivas descrições monográficas e contextualizações históricas encouraçadas? Como encontrar nexos entre o presente e o passado, entre o futuro e 0 presente, sendo esses, realidades concretas? Como desvendar a lógica dos tempos no movimento do real? Como ultrapassar as mediações das 
grandes questões teóricas sobre a cidade e o urbano, especialmente no que se refere aos aspectos quantitativos da análise urbana?

A compreensão do movimento da realidade concreta aqui proposta considerou uma démarche em que estrutura, forma e função, momentos e fases, rupturas e continuidades do processo de reestruturação do espaço se constituem em síntese na análise das relações enredadas na problemática socioespacial do Rio de Janeiro. O percurso dessa pesquisa se nutriu muito mais de problemas de uma situação concreta do que de intenções teóricas proclamadas. Essa análise se comprometeu em perseguir um método (LEFEBVRE, 1969) e não em aplicar teorias, mas buscando que a teoria se revele e se construa na exposição dos problemas (PALMEIRA, 1978).

A reestruturação do espaço, tomada aqui primeiramente como conceito e sintetizada como processo de significativo potencial explicativo na dinâmica da produção do espaço, está lançada nessa perspectiva manifesta do movimento: estruturação-desestruturação-reestruturação. Vemos nesse movimento um caminho interpretativo para a compreensão da dinâmica que produz e reproduz o espaço e "recria as condições gerais a partir das quais se realiza o processo de reprodução do capital" (CARLOS, 2008, p. 83).

Ao remexer a cidade de São Gonçalo, no contexto da metropolização fluminense, buscamos incrementos à problemática do espaço avançando na compreensão do processo de reprodução da sociedade, sob a lógica do capital que se revela na produção do espaço urbano fluminense e na crise urbana do Rio de Janeiro. Não se trata de ilustrar as teses lefebvrianas da Produção do Espaço, mas sim de perseguir o método que reconstitui e penetra o movimento de uma situação histórica concreta em que as contradições imanentes constituem-se como os problemas teóricos das transformações socioespaciais ${ }^{1}$ sob as determinações do modo de

\footnotetext{
${ }^{1}$ As transformações socioespaciais referem-se à alterações na dinâmica da ação social, que se realiza em um espaço determinado e em um período preciso. "Nessa perspectiva,
} 
produção vigente.

Acontece que o capitalismo conseguiu atenuar (sem as resolver) durante um século as suas contradições internas e, consequentemente, conseguiu realizar 0 crescimento durante esse século posterior ao Capital. Qual o preço disso? Não há números que o exprimam. Por que meios? Isso, sabemo-lo nós: ocupando o espaço, produzindo um espaço. (LEFEBVRE, 1973, p. 21).

A cidade de São Gonçalo está inserida na Região Metropolitana do Rio de Janeiro (RMRJ) desde a institucionalização, em 1974. Ocupa o $16^{\circ}$ lugar no ranking das mais populosas do Brasil, atingiu a marca de população milionária e possui, atualmente, 1.049.826 habitantes². Classificada como a Manchester Fluminense entre as décadas de crescimento e desenvolvimento industrial e pós anos 1960 como subúrbio dormitório. Lembrada pela baixa infraestrutura em pavimentação e saneamento básico, fraca acessibilidade e mobilidade urbanas $^{3}$, poucos espaços públicos ou comuns ao lazer da população, baixo dinamismo econômico e efêmera geração de emprego e renda, não se destacando para além da média de 2,2 salários mínimos per capita ${ }^{4}$. Para alguns, eclipsada pelos altos índices de desenvolvimento da vizinha Niterói, jaz em sua condição periférica; uma outra análise, porém, apresenta-as como cidades-gêmeas (MENDES, 1950) - uma vez que a condição periférica é condição da formação econômico-social ${ }^{5}$ a qual está inserida, poder-se-ia acrescentar.

as relações sociais se realizam na condição de relações espaciais, o que significa que a análise geográfica revela o mundo como prática sócio-espacial" (CARLOS, 2011, p. 13).

2 Instituto Brasileiro de Geografia e Estatística (IBGE), estimativa de 2017.

${ }^{3}$ Especialmente após a desativação dos ramais ferroviários das Estradas de Ferro Maricá (em 1964) e Leopoldina (em 2006) e da experiência breve com a linha das barcas que conectava o distrito de Neves, em São Gonçalo, à Praça VI, na cidade do Rio de Janeiro (na década de 1940). Mesmo com o incremento do transporte viário essas ainda não foram recompensadas. São Gonçalo conta com aproximadamente 80 linhas municipais e 160 linhas intermunicipais de ônibus circulam pelos logradouros do território municipal integrando-o à dinâmica metropolitana através dos municípios de Niterói, Itaboraí, Magé, Duque de Caxias e Rio de Janeiro.

${ }^{4}$ IBGE, 2010.

5 "Trata-se de uma sociedade, de uma formação (por exemplo, da sociedade capitalista), como do conjunto da história e do desenvolvimento da sociedade" (LEFEBVRE, 1969, p. 190) ou a interação do econômico com o social a partir da qual encarna uma formação, 
Não sem motivo, São Gonçalo vem sendo perpetuada na memória coletiva fluminense e descrita em antigos e recentes trabalhos como subúrbio dormitório (GEIGER, 1956), periferia intermediária (ABREU, 2008), periferia metropolitana (LAGO, 2007); centralidade periférica (ROSA, 2018). Lugar de ausências e atrasos, da pobreza e do descaso. Feia, precária, esburacada, de trânsito caótico. Cidade de poucas oportunidades, de garagens abertas nas quais os moradores oferecem cardápios variados nos seus restaurantes improvisados. Área de risco, violenta, território de facções criminosas e de milícias que atuam na disputa pelo mercado de drogas e "serviços urbanos" (gás, tv e internet, mobilidade intra-urbana e, até mesmo, segurança...). Barulhenta! Mas todos os seus estrondos são discerníveis: com a segunda maior frota de veículos do estado do Rio de Janeiro, o ronco dos motores é tão audível quanto as buzinas dos automóveis diante de um cruzamento engarrafado; a força da fé estimulada pelos grupos neopentecostais só se abafa com o som dos tiros disparados das comunidades e complexos da periferia (territórios urbanos com enorme valor especulativo); carros e motos de som que propagam serviços; calçadas do comércio de rua que alcançam decibéis danosos; mas nenhum ruído é tão estimulante quanto os das conversas fiadas, das opiniões emitidas, das notícias anunciadas pelos que saíram mais cedo e cumprem seu calvário diário no trajeto casa/trabalho.

A partir de Lewis Mumford e sua maneira sensível de descrever as origens e as transformações pelas quais a cidade está sujeita - e todas as cidades estão -, voltamo-nos para São Gonçalo com o objetivo de compreende-la na sua relação com os processos urbanos em curso desde sua estruturação até a atual fase de urbanização. Mumford inicia sua reflexão na obra $A$ Cidade na História problematizando o pensamento sobre a cidade: $O$ que é? Como começou? Que processos promove? Quais funções exerce? Que finalidade tem? (MUMFORD, 2008, p. 1). Diante presente actual (a indústria moderna) um imenso passado e, por fim, a história inteira". (LEFEBVRE, 1969, p. 199). 
dessas indagações, o autor, apresenta a complexidade do pensamento sobre a cidade. Para ele, "Não há definição que se aplique sozinha a todas as suas manifestações nem descrição isolada que cubra todas as suas transformações", desta forma "[...] cumpre-nos compreender a natureza histórica da cidade e distinguir, entre as suas funções originais, aquelas que dela emergiram e aquelas que podem ser ainda invocadas." (MUMFORD, 2008, p. 1).

Essa perspectiva histórica inspira-nos a analisar as transformações pelas quais a cidade de São Gonçalo passou tendo na periodização das fases de rupturas e nas continuidades o movimento do processo de reestruturação do espaço ${ }^{6}$, como resultante e constitutivo do processo de produção do espaço: de subúrbio agrícola e industrial à subúrbio dormitório à cidade metropolizada - não apenas no sentido da institucionalização de uma região, mas na relação com o espaço metropolitano e com os processos socioespaciais característicos desse contexto urbano.

Para essa análise espacial recorremos às categorias forma-funçãoestrutura (LEFEBVRE, 1971, 2000) como instrumento metodológico para o corte dos diferentes momentos do processo de reestruturação do espaço que, pensados a partir de São Gonçalo, buscou-se caracterizar as fases de ruptura e os elementos de continuidade que vêm atendendo pelo nome de transformações socioespaciais; contudo, acreditamos não se tratar de uma transformação do movimento, mas sim do movimento em transformação. O corte e montagem, conforme proposto por Lefebvre e perseguido nesse trabalho através da tríade forma-função-estrutura, sugere que nas noções de ruptura e continuidade revelam-se a gênese e metamorfose dos processos socioespaciais do movimento em

\footnotetext{
${ }^{6}$ Em relação a noção de reestruturação adotou-se o complemento nominal "do espaço" em detrimento de outros complementos adjetivos. Porém, esse conceito, seus usos e suas várias adjetivações merecem problematização teórica e metodológica e buscaremos faze-la no desenvolvimento desse trabalho.
} 
transformação que não pode ser confundido com a transformação do movimento, mas devem, para esse, apontar como possibilidade do devir.

Chamamos de movimento em transformação ${ }^{7}$ o curso da realização concreta da sociedade sob as determinações do modo de produção capitalista que se concretiza em atenuantes contradições que não se superam. Referimo-nos à transformação do movimento ${ }^{8}$ o devir inaugurado sob outras determinações nas relações sociais de produção.

O movimento em transformação, considerando as metamorfoses da forma urbana, tem "aparência de caos" pois dinamiza-se por diversas estratégias (SEABRA, 2003, p. 48). Logo, as transformações socioespaciais que observamos e analisamos são características dos períodos ou fases do desenvolvimento socioeconômico sob determinações históricas. Considerando a perspectiva teórica da produção do espaço, tais transformações socioespaciais $^{9}$ não se explicam em si mesmas, pois dinamizam-se em rupturas e continuidades que encarnam períodos e fases do movimento total da urbanização. A análise da reestruturação do espaço é, aqui proposta, como princípio interpretativo desse movimento e da compreensão de seus nexos espaço-temporais.

O trabalho de Seabra sobre um bairro da cidade de São Paulo aponta para a materialidade e a impossibilidade do mesmo quando

\footnotetext{
7 Propomos também chamar de metamorfoses de um desenvolvimento econômico-social.

8 Acrescentamos ainda que o que chamamos de transformação do movimento não é pensado como impossibilidade real, pois gesta-se nas manifestações insurgentes, a partir das quais se busca alcançar o utópico. No contexto da sociedade urbana, a transformação do movimento é tão possível como impossível é o eterno reino da crise.

9 Marcelo Lopes de Souza chega a dizer que "é tolice, como acreditam muitos urbanistas, que meras transformações espaciais poderiam mudar a sociedade, tornando-a mais harmônica, porque pretensamente mais racional" (SOUZA, 2005, p. 28). A esse raciocínio, ainda acrescentaríamos ser quase ingênua a análise que considera as transformações socioespaciais como um caminho evolutivo da sociedade rumo à superação de suas contradições, posto que, sob a lógica capitalista, tais transformações se dão no contexto e no pretexto da reprodução das relações sociais de produção. Por isso a importância que damos ao método que insiste na compreensão do movimento concreto do real, sendo o período atual caracterizado pela subordinação de todas as relações e também do espaço à lógica de reprodução do capital (LEFEBVRE, 1973, p.19). "É nesse momento que o modo de produção domina os resultados da história [...]" (LEFEBVRE, 1973, p. 9).
} 
compreendido sob as lentes da fragmentação espacial no curso da realização do processo social de metropolização do espaço. Seabra persegue o movimento das transformações socioespaciais no domínio do urbano e alcança o entendimento de que "há um processo com momentos e circunstâncias que precisam ser compreendidos, no movimento que vai da cidade à metrópole" (SEABRA, 2003, p. 40). Para isso, a geógrafa considera as configurações espaciais, em uma espécie de dialética espacial, que recoloca o bairro na história urbana de São Paulo e, no caminho de volta à síntese, explica sua transfiguração. A partir de Seabra, temos a compreensão de que a forma urbana é também período, fase do movimento total e como tal precisa ser compreendida no movimento da urbanização como um processo total.

Para descobrir a essência dos processos socioespaciais, na perspectiva da reestruturação do espaço, vimos a necessidade de percorrer o caminho das transformações (do movimento em transformação) a partir de conceitos. Ora, se considerarmos o conceito como uma abstração do todo, logo a realidade apreendida em conceitos ou categorias abstratas torna-se concreta, contudo é a partir das lógicas da produção do espaço (movimento interno) que compreenderemos a realidade que os conceitos apreendem.

Burgel apresenta em seus trabalhos (1993, 2015a, 2015b) uma preocupação teórica sobre a cidade e a realidade urbana. Para o autor, é preciso avançar para além dos temas e considerar que "a famosa crise da cidade seria antes de tudo uma crise das nossas ideias sobre a cidade"10, dessa forma, "devemos primeiro rever, legitimar e relativizar as definições clássicas da cidade"11 (BURGEL, 2015b, p. 7). Para Burgel, o período atual consiste em três formas de cidades que se sobrepõem na realidade concreta, tanto no Sul quanto no Norte, desde a metade do último século:

\footnotetext{
10 Texto original: «la fameuse crise de la ville était avant tout une crise de nos idées sur la ville »

11 Texto original: «il fait d'abord passer en revue, légitimer et relativiser les définitions classiques de la ville »
} 
cidade fechada, cidade rede e cidade total ${ }^{12}$ (BURGEL, 2015b. p. 8). A cidade e a realidade urbana são cada vez mais concretas, entretanto, precisam ser lidas "sob as representações do espaço"13" (Idem, p. 8). É, inclusive, nessas tentativas de leituras e abordagens sobre as representações do espaço que se abrem os caminhos da inteligibilidade crítica e sua produção.

O desenvolvimento do pensamento sobre a realização histórica da sociedade não se faz sem uma necessária revisão do arcabouço teórico que herdamos. Para Lencioni "na medida em que o conceito é um reflexo do real e esse real está em permanente mudança, é lógico que ele [o conceito] também se modifique", ou seja, "o conceito existe em movimento" (LENCIONI, 2008, p. 111).

A necessária discussão acerca dos conceitos ou noções que revelam a natureza e os meandros das transformações e metamorfoses socioespaciais consiste em reunir os termos que, tornados conceitos ou noções, buscam apreender os processos, dinâmicas e fenômenos que realizam a sociedade e se realizam através das relações sociais, analisam seus limites e repensar suas possibilidades reveladoras.

A noção de transformação como possibilidade de interpretação histórica da sociedade vem sendo associada às dinâmicas da cidade e de sua aglomeração desde os primórdios. Contudo essa noção também se modificou ao longo do tempo nas abordagens e na construção de um léxico conceitual, especialmente no campo da investigação geográfica.

Abreu em seu minucioso artigo Estudo geográfico da cidade no Brasil, destacou que, considerando a influência das escolas alemã e francesa percebemos que o estudo sobre a cidade se modifica já nos seus primórdios, quando os pesquisadores do tema ampliam o conceito/noção de posição ou situação para o de sítio, influenciados pelas obras de Ratzel

\footnotetext{
12 Texto original: « la ville fermée, la ville réseau et la ville totale »

13 Texto original: « sur les representations de l'espace »
} 
e La Blache, respectivamente. E é nessa nova compreensão da cidade e do fenômeno urbano, ainda no final do século XIX, que a ideia de transformação parece ser introduzida ao debate e aos estudos urbanos. Isso porque, o conceito/noção de sítio insere-se nas pesquisas geográficas com uma abordagem naturalista, ressaltando que a cidade seria "mais um palco de demonstração da superioridade da vontade humana" e de "grandes vitórias humanas sobre o meio natural" (ABREU, 1994, p. 2223). Em outras palavras, a cidade seria a expressão da capacidade transformadora do homem.

As noções de crescimento e evolução do meio a partir da cidade e do fenômeno urbano alcançam outras elaborações teóricas e metodológicas com os estudos sistemáticos de Ecologia Humana da Escola de Chicago (ABREU, 1994, p. 24). No Brasil, a Escola de Chicago e o pensamento moderno francês no domínio das ciências humanas e sociais influenciaram largamente a produção teórica dos estudos urbanos, especialmente entre as décadas de 1940 e 1950. Por conseguinte, os anos 1950 e 1960 marcaram a predominância dos estudos urbanos a partir do eixo urbano-regional e do planejamento territorial. Já nos idos dos anos 1960 e 1970, a temática da metropolização inseriu-se nos debates e na produção acadêmica explicitando o caráter metropolitano da questão urbana (ABREU, 1994, p. 37-42).

O nosso interesse, ao apresentar esse breve resumo de um longo percurso das pesquisas e estudos urbanos, é sublinhar a importância de perceber que nas diferentes abordagens, a partir das quais a cidade e 0 fenômeno urbano vêm sendo trabalhados, encontra-se o problema das transformações socioespaciais. Essas carregam um elemento essencial para a compreensão do real: o movimento. Sendo as relações sociais e o espaço a mediação para a compreensão das questões sobre o processo de reestruturação. Dessa forma, nossa abordagem metodológica buscou evidenciar, a partir dos conceitos e noções já anunciados, o movimento de realização da sociedade. Mas aquela sociedade anunciada por Lefebvre 
como virtualidade nos anos 1970 e, na fase atual, realizando-se como produto da urbanização completa da sociedade, a sociedade urbana. Nas palavras do autor.

Partiremos de uma hipótese: a urbanização completa da sociedade. Hipótese que posteriormente será sustentada por argumentos, apoiada em fatos. Esta hipótese implica uma definição. Denominaremos "sociedade urbana" a sociedade que resulta da urbanização completa, hoje virtual, amanhã real. (LEFEBVRE, 2008, p. 15)

A hipótese proposta por Lefebvre possui uma dimensão teórica e uma dimensão prática. A primeira refere-se ao aprofundamento teórico como premissa do pensamento científico e que contribui para uma visão mais ampla das complexidades e possibilidades do real; mesmo ainda não concretizado, mas em curso. A dimensão prática, refere-se às ações "em que a busca das soluções e das modalidades próprias à sociedade urbana passará ao primeiro plano" (LEFEBVRE, 2008, p. 19).

A expressão "sociedade urbana" responde a uma necessidade teórica. Não se trata simplesmente de uma apresentação literária ou pedagógica, nem de uma formalização do saber adquirido, mas de uma elaboração, de uma pesquisa, e mesmo de uma formação de conceitos. Um movimento do pensamento em direção a um certo concreto e talvez para o concreto se esboça e se precisa. Esse movimento, caso se confirme, conduzirá a uma prática, a prática urbana, apreendida ou re-apreendida. (LEFEBVRE, 2008, p. 18).

A importância de nossa abordagem pode ser justificada pelo fato dessa considerar a hipótese lefevriana sobre o ritmo da urbanização mundial não mais como virtualidade, mas como realidade, haja vista a relevância da problemática urbana nas últimas quatro décadas. O pensamento sobre a cidade e o urbano acirrou-se. O volume de trabalhos científicos, relatórios técnicos e de gestão é surpreendente. A preocupação de pesquisadores, gestores, políticos, promotores, investidores, militantes e cidadãos em geral cada vez mais estreita-se em pautas sobre a cidade e o urbano, e mais especificamente sobre as transformações e os caminhos da realidade urbana ainda não acabada, mas em plena realização. 
A problemática urbana nem está na moda nem tornou-se um clichê, ela está na ordem do pensamento contemporâneo porquê a sociedade urbana se tornou real. O crescimento acelerado e planetário das aglomerações urbanas carece de reelaboração teórica e prática, pois simultaneamente sobre ele paira uma ameaça.

Essa extensão mundial não virá sem um grande risco de
homogeneização do espaço e de desaparecimento das
diversidades. Ora, a homogeneização se faz acompanhar de
uma fragmentação. O espaço se divide em parcelas que se
compram e se vendem. Seu preço depende de uma
hierarquia. (LEFEBVRE, 1989, p. XX).

A geografia urbana, como campo interessado pela formação do tecido urbano e pelas complexidades do fenômeno urbano através da história, dedica-se a desvelar a multiplicidade das formas e das civilizações urbanas (CLAVAL, 1981). E esse esforço de compreensão do fenômeno urbano contribuiu para a construção de um léxico conceitual e escolhas metodológicas diversas - já sinalizamos as nossas. Estamos, pois, interessados em analisar e discutir o movimento das transformações socioespaciais no contexto da urbanização como processo histórico. Entretanto, a discussão aqui apresentada é parte integrante da investigação que se insere em um campo de análise ainda mais ambicioso: revelar a gênese das transformações socioespaciais através da análise do processo de reestruturação do espaço, suas rupturas e continuidades relacionando-o ao movimento e aos momentos da produção do espaço metropolitano fluminense no qual se insere a cidade de São Gonçalo.

As preocupações com os agentes, os processos, os momentos na análise da produção do espaço acumularam-se à medida em que desenvolvíamos uma pesquisa sobre a evolução e a estruturação urbanas da Cidade de São Gonçalo em ocasião do mestrado ${ }^{14}$. Conforme caminhávamos no tempo e no espaço históricos da (re)produção do

${ }^{14}$ A dissertação foi intitulada "Evolução e Estruturação Urbanas de São Gonçalo: do final do século XIX à Segunda Guerra Mundial". 
urbano em São Gonçalo éramos trazidos à reflexão sobre as transformações do presente e as tendências futuras da estrutura metropolitana fluminense e a relação dessa com formas e funções urbanas ainda não dissolvidas.

Nossa preocupação também se tornou a análise dos processos de estruturação e reestruturação do espaço metropolitano fluminense como proposta interpretativa das dinâmicas da metrópole, sua região e seus eixos de reprodução. Especialmente no Rio de Janeiro, o estudo da metropolização buscou privilegiar a compreensão dos processos engendrados na metrópole com pouca interface em relação à sua região. Possivelmente pelas intempéries políticas e econômicas já conhecidas no processo de conformação e consolidação da Região Metropolitana do Rio de Janeiro (RMRJ) devido a demorada reincorporação da Cidade do Rio de Janeiro - tornada Estado da Guanabara após a transferência da Capital Federal para Brasília, em 1960 - ao Estado do Rio de Janeiro que só se tornou possível com a fusão político-territorial através da Lei Complementar $\mathrm{n}^{\circ} 20$, de $1^{0}$ de julho de 1974. Sobre esse assunto, Floriano de Oliveira destaca que "com a manutenção da proposta constitucional de criação de um novo estado, o Estado da Guanabara, emergem duas crises no território fluminense: uma política e outra econômica" (OLIVEIRA, 2003, p. 70). Consideramos pertinente, ainda, falar de uma terceira "crise" concomitante às duas outras apresentadas por Oliveira: se singulariza no território fluminense uma crise urbana de caráter metropolitano, no sentido do fraco alinhamento regional metropolitano posto pela dificuldade de incorporação da metrópole à sua região que se encontravam institucionalmente desincorporadas, territorial e economicamente fragmentadas até 1974.

Dessa forma, acreditamos que a análise da reestruturação do espaço, a partir de São Gonçalo, contribui também para aguçar a problemática acerca das dinâmicas metropolitanas, uma vez que essa análise se fez a partir da caracterização das rupturas e identificação das 
continuidades das relações sociais de produção contidas no espaço de conformação da cidade - eis um desafio na interpretação das transformações socioespaciais: a dimensão da reprodução.

A escolha dos elementos espaciais (tais como: as indústrias, as instituições, os espaços de consumo, lazer e moradia, as infraestruturas visíveis e invisíveis, os agentes sociais, etc), a identificação e a análise das rupturas como também a sensibilidade de indicar a absorção desses elementos às condições distintas do movimento histórico permite-nos uma proposta de periodização dos diferentes níveis da realidade espacial e auxilia-nos na reconstituição do tempo e do espaço como categorias simultâneas de análise. Seja qual for a natureza do processo (econômica, cultural, social, política), intrínseca à sua natureza estará a concepção de movimento. Ao movimento inserem-se aparente coerências e insuperáveis contradições, mudanças e permanências que compõem a lógica das transformações socioespaciais. Essas são possíveis de materializarem-se pela mediação das relações sociais de produção e do espaço.

Logo, ao considerarmos a reestruturação do espaço como uma noção interpretativa e como um processo, verificados a partir da análise das rupturas e continuidades na produção do espaço em São Gonçalo, assumiremos a possibilidade de periodização dos seus diferentes momentos, definindo fases onde serão reunidas as características e a predominância dos elementos que compõem o espaço. A definição de fases é também um instrumento de reconstituição do espaço em busca de compreendê-lo em sua totalidade, da gênese à evolução, refletindo já sobre suas tendências, já que o espaço não é ontem, nem hoje, e sim a totalidade de tempos que materializam-se através das formas e das funções, por meio de estruturas.

Nesse exercício analítico é necessário considerar uma regra proposta por Lefebvre: evitar a confusão da continuidade ilusória tanto quanto as separações ou descontinuidades absolutas afim de permitir que o estudo das articulações entre os níveis da realidade possa "pôr em evidência as 
distorções e defasagens entre esses níveis, e não dissolvê-las." (LEFEBVRE, 2006, p. 52).

Por meio da combinação das categorias analíticas forma-funçãoestrutura, utilizadas como instrumento metodológico, nos será permitida uma análise do real considerando as "estabilidades provisórias e os equilíbrios momentâneos" (LEFEBVRE, 1971, p. 189) através dos quais se revela o conteúdo espacial. Para Lefebvre, a forma urbana congrega um movimento de explosão e implosão, ou seja, a partir da implosão a "vida urbana concentra e se acentua no que resta da antiga morfologia (cidades e bairros)"; e a partir da explosão a vida urbana "tende a existir como forma nova que espera por uma base morfológica; $[. .$.$] provocando o$ questionamento das formas existentes e do modo de existência (social e metal) das formas" (LEFEBVRE, 1991, p. 188). As formas se materializam pelas relações concretas entre os indivíduos e por isso se expressam na historicidade das relações sociais, atreladas ao conteúdo da vida urbana que determina suas funções dentro de uma estrutura organizada social e espacialmente. A tríade forma-função-estrutura revela a dinâmica da produção do espaço, espaço que responde às alterações da sociedade a medida que ele, o espaço, também a altera, resultando na transformação dos lugares, de seu conteúdo e de suas gentes.

Assim, as transformações socioespaciais se tornam, a problemática da produção do espaço sob as lentes da reestruturação, revelando as rupturas e continuidades no movimento de realização da sociedade urbana. Quando a reestruturação se inicia há uma descontinuidade no movimento dos processos engendrados provocando uma ruptura, resultando em mudanças e que, segundo Soja: "[..] evoca pois, uma combinação sequencial de desmoronamentos e reconstruções, de desconstruções e tentativas de reconstruções" (SOJA, 1993, p. 193). Os desmoronamentos, as reconstruções, as desconstruções e as tentativas de reconstruções nos sugerem a dinâmica do movimento em transformação. 
Destacamos que o objetivo dessa pesquisa consiste em compreender a produção do espaço a partir das fases do processo de reestruturação, suas rupturas e continuidades, tendo como situação concreta a realidade urbana de São Gonçalo (RJ). Assumindo esse objetivo surgem questões sobre as quais construímos nossa hipótese: A) quais as rupturas que caracterizam cada fase do processo de reestruturação do espaço em São Gonçalo? e, B) qual a relação dessas rupturas com a realidade metropolitana fluminense? $\mathrm{E}$, considerando uma perspectiva histórica na análise da produção do espaço, C) quais as continuidades encobertas em cada momento de ruptura? D) é possível compreender a reestruturação do espaço como um álibi à reprodução do capital? A busca por respostas a essas questões nos fez percorrer o movimento socioespacial que conformou e transfigurou a realidade urbana da cidade de São Gonçalo.

Consideramos a conformação do espaço urbano de São Gonçalo como um marco importante da primeira fase do processo de reestruturação do espaço (1890 a 1930). No momento em que essa urbanização ganha impulsos de um outro processo, o de industrialização, entre as décadas de 1930 e 1970, no contexto da prosperidade econômica, já favorecida pelo sucesso das atividades agrícolas e, posteriormente, pelo incremento da atividade industrial, algumas mudanças anunciavam transformações socioespaciais - toda transformação materializa-se no âmbito de um movimento, aqui recorremos à análise dessas transformações para compreender a lógica da produção do espaço a partir do movimento da urbanização fluminense.

Vemos em São Gonçalo os momentos de ruptura resultando em diferentes momentos da urbanização que caracterizam as fases da reestruturação do espaço e evidenciam mudanças na forma, na estrutura e na função urbanas da cidade. Se no período que corresponde a estruturação urbana do município identificamos uma urbanização que precede à industrialização e uma estrutura espacial organizada, 
inicialmente, na área central movida pelos interesses das classes mais abastadas, vemos em outros espaços da cidade, na forma de conurbação com Niterói (Capital do Estado do Rio de Janeiro até então), uma urbanização que permite a industrialização, ao mesmo tempo em que a industrialização constrói para si a urbanização que precisa, com a instalação de vilas operárias, empreendimentos industriais, ampliação dos serviços e comércio. Esses diferentes momentos do processo de urbanização estão diretamente relacionados ao processo de reestruturação do espaço.

A consolidação da industrialização conduziu São Gonçalo, evidentemente, a um novo modelo de produção e reprodução do espaço e da vida urbana. Para Lefebvre "ela [a indústria] ataca também a Cidade (cada cidade), assalta-a, toma-a, assola-a [e] tende a romper os antigos núcleos, apoderando-se deles" (LEFEBVRE, 2006, p. 9). Dessa maneira temos a industrialização em São Gonçalo como um importante indutor da urbanização, e simultaneamente, das, primeira e segunda, fases de reestruturação.

Entre as décadas de 1920 a 1940, a instalação de indústrias extrativas e de transformação se deu de forma territorialmente sucessiva concentrando-se no eixo entre os bairros Neves (bairro a sudoeste da área central de São Gonçalo e fronteiriço à Niterói) e Alcântara (bairro distante 5 quilômetros $(\mathrm{Km})$ da área central de São Gonçalo). A principal característica da industrialização de São Gonçalo era a diversidade de seus ramos $^{15}$. Entre as décadas de 1940 e 1990 a industrialização gonçalense consolidou-se, teve seu apogeu e declinou. O fechamento ou transferência

\footnotetext{
15 Podemos citar como exemplo as seguintes indústrias: Companhia Brasileira de Usinas Metalúrgicas - HIME (1920); Companhia Eletroquímica Fluminense (1933); Companhia Nacional de Cimento Portland (1933); Indústrias Reunidas de Pesca S.A. Netuno (1941); Companhia Vidreira do Brasil - COVIBRA (1941); Companhia Industrial de Papéis Alcântara (1945); Companhia Fiat Lux (1904); Fábrica de Doces Sublime (1941); Indústria de Conservas Coqueiro (1937); Conservas Rubi (1934); Conservas de Peixe Piracema (1940); Indústrias Reunidas Mauá (1941); Companhia S.A. Internacional do Brasil (1927); Cerâmica Porto do Rosa (1941); Indústria de Cerâmica Fatore (1941), dentre outras.
} 
de unidades industriais, a diminuição do emprego, o surgimento de unidades habitacionais de característica suburbana, como os condomínios populares, os conjuntos residenciais e a fundação de bairros destinados à moradia (FERNANDES, 2012, p. 37) marcaram a consolidação da segunda e a eclosão da terceira fase de reestruturação do espaço em São Gonçalo. A partir daí novas formas, diferentes funções para formas antigas e uma estrutura urbana mais complexa superam o tempo e subordinam o espaço. O atual momento da dinâmica espacial de São Gonçalo, refere-se, em nossa proposta interpretativa, a terceira fase, muito mais complexa que as anteriores por não ser parte, mas por representar a totalidade ao longo do processo de produção do espaço.

Para esse terceiro momento, tomamos como referência o pensamento de Gottdiener ao interpretar a reestruturação do espaço nos Estados Unidos. Para o autor, o processo de reestruturação ganha uma "força" gerada pelo processo de desconcentração, herdado da estrutura metropolitana da organização e produção do espaço estadunidense. Segundo ele

Pela sua própria natureza, a desconcentração abrange tanto a reestruturação de áreas anteriormente agrícolas e recreativas, tornadas subúrbios, e a reestruturação das áreas centrais para ajustarem à dispersão da população e das atividades econômicas. [...]. Consequentemente, a reestruturação associada às forças de desconcentração implica não só mudanças que ocorrem no nível das forças e relações de produção e reprodução, mas também uma dimensão espacial: mudanças decorrentes da desconcentração do próprio espaço urbano, com a nova forma espacial retroagindo sobre suas próprias características internas, para efetuar mudanças adicionais. (GOTTDIENER, 1990, p. 60).

Para esse sociólogo, é a forma espacial, retroagindo sobre si mesma, em busca de mudanças adicionais às demandas socioespaciais que inscrevem o processo de reestruturação na produção do espaço. Considerando a interpretação de Gottdiener e refletindo a partir da realidade urbana de São Gonçalo, inserido no contexto da metropolização 
fluminense, destacamos o processo de periferização do tecido urbano, posta a premissa de que "a produção do espaço induzida pelo processo de industrialização, conduz à periferização, o que equivale ao aniquilamento das formas históricas de apropriação social do espaço" (SEABRA, 2003, p. 13). Esse aniquilamento, compreendido através da noção de espoliação urbana (KOWARICK, 1993; 2000), produz a fragmentação que desvela, em uma ponta a segregação e na outra a desigualdade como produtos intrínsecos do movimento histórico que realiza a urbanização em tempos pretéritos e no atual. Em definição, a espoliação a qual nos referimos

É o somatório de extorsões que se opera pela inexistência ou precariedade de serviços de consumo coletivo, que juntamente ao acesso à terra e à moradia, apresentam-se como socialmente necessários para a reprodução dos trabalhadores e aguçam ainda mais a dilapidação decorrente da exploração do trabalho, ou, o que é pior, da falta deste. (KOWARICK, 2000, p. 22).

Periferização, espoliação e segregação: forma urbana da fragmentação, função expropriativa de reprodução da força de trabalho e estrutura hierarquizada sob o valor de troca. Para Lefebvre (1969), "no curso do desenvolvimento, formas transformam-se em funções e entram em estruturas que as retomam e as transformam" (assim como se sucederam a cidade comercial, a cidade industrial e a cidade moderna), ou simplesmente, "uma forma, que se tornou função, entra em novas estruturas" (LEFEBVRE, 1969, p. 54). O fundamento para a perspectiva analítica que propomos encontra-se no mesmo autor.

Formas, estruturas e funções urbanas (na cidade, nas relações da cidade com o território influenciado ou gerido por ela, nas relações com a sociedade e o Estado) agiram umas sobre as outras e se modificaram, movimento este que - pensamento pode hoje reconstruir e dominar. Toda formação urbana conheceu uma ascensão, um apogeu, um declínio. Seus fragmentos e restos serviram sem seguida para/em outras formações. Considerada em seu movimento histórico, em seu nível específico [...], a Cidade passou por períodos críticos. Desestruturações e reestruturações se sucederam no tempo e no espaço, sempre traduzidas para a prática, inscrita no prático-sensível, escritas no texto 
urbano, mas provenientes de outro lugar: da história, do devenir. (LEFEBVRE, 1969, p. 54-55).

Assim, reconstruir o movimento da produção e reprodução do espaço, considerando o exemplo de São Gonçalo, é compreender o processo de reestruturação como possibilidade interpretativa de suas rupturas e continuidades na realização da metropolização fluminense. De acordo com Davidovich (1999) a metropolização fluminense e suas recentes alterações na estrutura espacial da Região Metropolitana do Rio de Janeiro "levam a observar tendências de reestruturação [...] tendências essas que estariam se manifestando em sua setorização do espaço" (DAVIDOVICH, 1999, p. 6). Esta afirmação de Davidovich reforça nossa perspectiva de análise, no sentido de que não há como considerar as mudanças ocorridas em São Gonçalo sem perceber as articulações e o contexto metropolitano das transformações recentes e das que produziram mudanças históricas no espaço ao longo do tempo. São Gonçalo é um dos "setores" do espaço metropolitano fluminense, um fragmento da reprodução da metrópole ${ }^{16}$.

A tese que apresentamos é que a dinâmica da produção do espaço urbano de São Gonçalo, inserida na conformação do espaço metropolitano fluminense, pode ser compreendida a partir de fases da reestruturação do espaço, suas rupturas e continuidades. A análise propõe dois momentos determinantes na dinâmica, o urbano-industrial e o metropolitanofinanceiro, e considera três fases críticas do processo de reestruturação:

${ }^{16}$ Davidovich sinaliza alterações recentes na estruturação da Região Metropolitana do Rio de Janeiro (RMRJ). Sua tese aponta para uma reestruturação setorizada do espaço, na qual o primeiro setor de reestruturação da RMRJ refere-se à cidade do Rio de Janeiro e sua esmagadora concentração de empreendimentos e iniciativas de reestruturação socioespacial. Destacando-se, sem precedentes, a Zona Leste na Cidade, especialmente os bairros da Barra da Tijuca, Jacarepaguá e Campo Grande. O segundo setor de reestruturação da RMRJ refere-se ao eixo comandado por Niterói, na porção oriental da Baía de Guanabara, numa "agregação de municípios" metropolitanos como São Gonçalo, Itaboraí e Maricá. O terceiro setor de reestruturação da RMRJ refere-se a Região da Baixada Fluminense, onde os eixos de comunicação viária tendem a reforçar as relações já estabelecidas desta porção do território metropolitano com a metrópole fluminense. Neste setor estão incluídos os municípios de Belford Roxo, Duque de Caxias, Guapimirim, Itaguaí, Japeri, Magé, Mesquita, Nilópolis, Nova Iguaçu, Paracambi, Queimados, São João de Meriti e Seropédica (Davidovich, 1999). 
1) a urbanização que precede a industrialização e é capturada por ela; 2) a urbanização espoliadora; e 3) a urbanização especulativa (ou financeira) que impõe à problemática urbana análises e interpretações para além do dualismo centro-periferia no contexto da atual conformação da metrópole e de sua região.

A periodização proposta combina a conexão de elementos dissolvidos em cada uma das fases identificadas, evidenciando, assim, as continuidades que coexistem aos novos arranjos característicos de cada fase de reestruturação, bem como identifica a ruptura que inaugura essas mesmas fases sem superar as contradições do desenvolvimento histórico. Esse movimento do pensamento reconstrói o movimento concreto que submetemos à análise. Para dar conta dessa problemática foram estruturados três capítulos.

O Capítulo I, intitulado "Da problemática urbana à crise urbana do Rio de Janeiro: São Gonçalo como expressão da complexidade metropolitana", voltamo-nos para a problemática urbana, considerando-a a partir das isotopias (as analogias), heterotopias (as diferenças) e utopias (o possível) da crise urbana do Rio de Janeiro - é como descrever o caos da realidade urbana de uma síntese interpretativa. Nesse capítulo todos os elementos da análise aparecem conjugados, justapostos.

No Capítulo II, "Produção do espaço metropolitano fluminense: dinâmica e processos na análise espacial", buscamos discutir a simultaneidade e a dinâmica entre os processos de produção e reestruturação do espaço, identificando as fases críticas do movimento, no qual eclode rupturas que imprimem novos ritmos à urbanização ao mesmo tempo que carrega continuidades, por vezes, encobertas perante novas possibilidades de realização da sociedade, do seu espaço e de seus tempos.

O Capítulo III, "Rupturas e continuidades: um ponto de vista para a problematização da realidade urbana", incorpora as reflexões elaboradas 
através da pesquisa desenvolvida no exterior no âmbito do laboratório Espace, Nature et Culture (ENEC), vinculado ao Institut de Géographie da Université de Paris-Sorbonne IV, sob a supervisão do Professor Paul Claval. Essa etapa da pesquisa buscou analisar e discutir os usos e os sentidos dos conceitos tomados como princípios interpretativos para expressar as transformações socioespaciais pelas quais a aglomeração urbana de Paris vem passando. Tal recurso nos proporcionou a expansão da problemática em contextos diversos e, por isso, uma compreensão mais ampla da realidade urbana total. A urbanização na França e no Brasil, aglomeração urbana de Paris e do Rio, cada aglomeração uma formação, cada formação uma reestruturação (ou reestruturações). O movimento do pensamento nos permitiu descrever o movimento dos processos engendrados na sociedade urbana fluminense, apresentado a partir da tríade periferização-espoliação-segregação.

Por todos os pontos aqui apresentados e diante da exposição que se segue, esperamos que a leitura dessas páginas possa levantar mais problematizações a ponto de superar aquelas que nortearam nosso percurso investigativo. 


\section{CAPÍTULO 1}

DA CRISE URBANA À PROBLEMÁtICA URBANA DO RIO DE JANEIRO: SÃO GONÇALO COMO EXPRESSÃO DA COMPLEXIDADE METROPOLITANA 

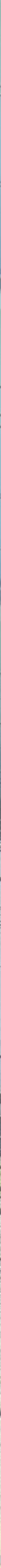


\subsection{Rio metropolitano: concentração e centralização, dispersão e fragmentação}

A última década do século $X X$ e a primeira do século XXI compreendem o intervalo de tempo no qual é possível perceber intensas transformações espaciais pelas quais os espaços metropolitanos vêm passando dada a intensificação das dinâmicas dos processos em curso. A relação dos vários processos espaciais com o da produção do espaço merece novo destaque nas pesquisas sobre a metrópole e sua região, pois é na análise das implicações desses processos que alcançamos possíveis compreensões sobre as complexidades da nova configuração metropolitana. Elegemos para a análise desta problemática os processos de concentração e centralização da dinâmica territorial das atividades urbanas na área metropolitana fluminense - sob o pressuposto da dispersão e fragmentação de sua conformação espacial.

As novas dimensões da lógica de produção do espaço metropolitano inserem-se na relação entre a dinâmica territorial das atividades urbanas e a centralização de comando, gestão e fluxos (materiais e imateriais) e as implicações dessa relação na reestruturação do espaço. A partir dessa relação poderemos colaborar para a compreensão do processo de reestruturação do espaço manifesto pela reprodução do fato urbano de caráter metropolitano. Para tanto, examinaremos algumas hipóteses e considerações apresentadas por autores que vêm debruçando-se sobre a problemática desses processos em áreas metropolitanas a fim de contribuir para o entendimento das complexidades da Metrópole Rio ${ }^{17}$ e sua região.

Inspirados, especialmente, nas análises, hipóteses e contribuições

17 Com o termo Metrópole Rio referimo-nos a classificação dada a Cidade do Rio de Janeiro mediante sua polarização e influência em relação as cidades de seu em torno. Distanciamo-nos, assim, da definição utilizada por alguns autores fluminenses (NATAL, 2003; SOUZA, 2018) e pela Câmara Metropolitana de Integração Governamental do Rio de Janeiro $(2011 ; 2015)$ que referem-se a Metrópole Rio como sendo o conjunto da Cidade do Rio e sua região de influência. 
interpretativas de Lencioni, ao analisar a dinâmica metropolitana de São Paulo, e Davidovich, a do Rio de Janeiro, vimos que as transformações que configuram atualmente as novas diretrizes do urbano e das grandes aglomerações metropolitanas precisam ser analisadas com vista à uma compreensão da complexidade relacional dos processos espaciais em curso. Segundo essas autoras trata-se do debate a respeito da produção contemporânea do espaço (DAVIDOVICH, 2001a, p. 326) e que converge para destacar algumas das características da metrópole que se metamorfoseia nesse contexto trazendo à tona a importância da apreensão de processos espaciais tais como o de concentração e de centralização (LENCIONI, 2008a, p. 16) sob a égide do fortalecimento da territorialidade do capitalismo financeiro nos espaços da metrópole contemporânea, inaugurando um novo ciclo de reestruturação e subordinando as continuidades do processo civilizatório na dimensão do fenômeno urbano. A relação estabelecida entre a dinâmica territorial de concentração das atividades urbanas e a centralização de comando, gestão e fluxos (materiais e imateriais) na Metrópole Rio permite-nos uma visão mais atenta para o processo de reestruturação do espaço fluminense.

Previamente destacamos a tendência e o fato novo na perspectiva da compreensão da produção do espaço metropolitano e sua conformação na urbanização contemporânea. Sendo a tendência a histórica concentração das atividades urbanas na cidade do Rio de Janeiro e com isso o fortalecimento de sua centralidade. O novo repousa no fato de que com a reprodução da metrópole em direção aos eixos principais de sua aglomeração metropolitana, novas centralidades se reforçam através de uma configuração espacial intensificada por integrações regionais cada vez mais determinantes para a reprodução do capital e da manutenção de sua lógica perversa flagrante no processo de produção do espaço e da vida esse aspecto, especialmente, retornaremos mais adiante.

A reafirmação da centralidade da Cidade do Rio de Janeiro na fase 
da urbanização contemporânea não aniquila as centralidades ${ }^{18}$ em sua área de influência e na periferia metropolitana, contudo, amplia as fossas da fragmentação entre os territórios urbanos da aglomeração, não os desintegrando, ao contrário, fortalecendo uma dinâmica de homogeneização periférica e de hierarquização dominante.

Uma breve introdução à geografia histórica do Rio de Janeiro nos possibilita fornecer um panorama à problemática atual. Para Freitag a cidade do Rio de Janeiro era uma "cidade de itinerâncias urbanas". Segundo a autora, tornou-se a primeira referência de metrópole, ainda no período colonial, passando a "sediar o imaginário da cultura europeia e portuguesa" (FREITAG, 2009, p. 30). Nessa época, do início até meados do século XIX, especialmente com a transferência da Família Real e a Corte Portuguesa para o Rio de Janeiro e todos os privilégios e impasses que essa transferência poderia trazer, a Cidade do Rio de Janeiro extravasa em suas funções política, cultural, portuária, comercial. O Rio de Janeiro foi sede de todas as formas de poder instituídas desde 1763, ainda no período Colonial, até a ascensão de Juscelino Kubitschek ao poder, governo no qual se deu a transferência da capital federal do Rio de Janeiro para Brasília, em 1960.

De Capital Federal (1763-1960) à Estado da Guanabara (19601974) à Capital do Estado do Rio de Janeiro (1975 até o presente). Todas as funções citadas acima contribuíram para a efervescência do urbano no Rio de Janeiro desde o início do século XIX. O Rio de Janeiro teve sua evolução urbana alavancada por circunstâncias históricas e o desenvolvimento de suas funções proporcionado pela intensidade dos fenômenos políticos, econômicos e socioculturais responsáveis pela dinamização do seu território e pela autonomização da cidade - este último com reflexo negativo na integração territorial com o Estado do Rio de Janeiro após a transferência da capital para Brasília e a fusão entre os Estados da Guanabara e do Rio de Janeiro (DAVIDOVICH, 1999, p. 13).

${ }^{18}$ Sobre as centralidades da RMRJ ver SILVA (2016). 
A transferência da Família Real e da Corte Portuguesa para o Rio de Janeiro, conforme já citamos, trouxe implicações na organização e no desenvolvimento urbano da cidade, especialmente porque se instala no Rio o centro de gravidade do poder da Colônia e da Metrópole. É a partir do final do século XIX e as primeiras décadas do XX que as transformações na Cidade do Rio de Janeiro e na sua aglomeração imediata e intermediária ganham efeitos estruturantes para uma conformação espacial urbano-regional (ABREU, 2008; VIANA, 2013).

O Rio de Janeiro seguia como centro de poder e de riqueza, desenvolvendo para além de sua função político-administrativa, a centralização dos negócios e exportação do café, introduzidos em terras do Vale do Paraíba (leito do principal eixo rodoviário entre Rio-São Paulo). A expansão da cafeicultura e o movimento comercial desenvolveu, a partir do principal elemento estruturante da urbanização paulista, a ferrovia, uma rede de cidades que impulsionou as mais profundas transformações território de São Paulo. Esse conjunto de transformações proporcionou à economia urbana de São Paulo um fortalecimento que não ocorreu no Rio de Janeiro, onde a manutenção do trabalho escravo nas lavouras não oportunizou o mesmo efeito que em São Paulo com a mão de obra do imigrante (MONBEIG, 2004; MARTINS, 2010). Já na década de 1920, o Rio de Janeiro começa a perder importância em relação a São Paulo que, com o status de "locomotiva do Brasil", torna-se o centro dos negócios do café, da indústria e dos serviços financeiros, respectivamente.

Apesar da perda de importância no cenário nacional já a partir dos anos 1920 (NATAL, 2003, p. 427) o Rio de Janeiro estabelece com São Paulo um eixo dinamizador a partir do qual o processo de urbanização passa a agregar uma série de novas funções urbanas, novas formas e uma estrutura regional complexa, provenientes da contínua herança histórica de concentração das atividades urbanas por aquela cidade e do 
sucesso da cafeicultura por essa ${ }^{19}$.

Nesse sentido apresenta-se a tendência a qual nos referíamos anteriormente: a cidade do Rio de Janeiro possui aspectos históricos que a evidenciam em detrimento de outras cidades e metrópoles brasileiras e de sua própria aglomeração metropolitana, por nela gravitar a concentração e a centralização das atividades urbanas há mais de dois séculos. As funções que exerceu no passado a colocaram em conexão com o externo, com o de fora, devido as suas atividades político-administrativas e comerciais e nessa atual fase da urbanização metropolitana, continua a exercer conexão com o de fora, agora em uma perspectiva da globalização da economia e do capitalismo financeiro, pondo-se o desafio, também histórico, dos limites do crescimento econômico fluminense sustentado na sua metrópole e da pouca densidade produtiva de sua região (SOBRAL, 2015a; 2015b).

A explosão do fenômeno urbano na forma de regiões metropolitanas a partir da década de 1970. As inúmeras teorias sobre sua configuração, planejamento e criação de políticas públicas de interesse comum aos municípios integrantes a tais regiões instituídas marcaram os debates e ocuparam as pautas de pesquisadores e políticos. O futuro se anunciava e atendia pelo nome de metrópole. Passados pouco mais de 40 anos do marco institucional que oficializou os primeiras e mais consolidadas regiões metropolitanas do Brasil, seguidos da renovação dos debates e estudos urbanos para que se compreendesse melhor essa configuração espacial que era em si a superação da própria cidade. A metrópole parecia ser o ponto máximo da forma urbana. A cidade implodiu. A metrópole

\footnotetext{
19 É mister destacar que a natureza das relações sociais de produção constitui-se no principal fator de diferenciação entre as dinâmicas econômicas do Rio de Janeiro e de São Paulo. No Rio de Janeiro, essas relações baseavam-se em uma lógica escravocrata, sendo os exemplos mais claros, a organização do trabalho nos sistemas produtivos do médio Vale do Paraíba e a consolidação de núcleos favelados e periféricos na metrópole e no seu em torno (CAMPOS, 2005). Em São Paulo, as relações de produção assalariadas permitiram novos elementos, sob outras lógicas, à organização do trabalho e à recomposição territorial. Tais elementos, todos necessários, a essa nova estruturação da produção: novas relações socais de produção e de reprodução (MARTINS, 2010).
} 
explodiu.

A urbanização mostrou-se um processo tão complexo, capaz de atingir fases pouco cogitadas: da vila à cidade, da cidade à metrópole, da metrópole à cidade-região (LENCIONI, 2006; BERNARDES e SOARES, 1990; SCOTT et al. 2001). Na fase atual o marco espaço-temporal não é mais a cidade e sua função política e administrativa, mas a metrópole policêntrica e dispersa. Estamos diante da metropolização do espaço. Da difusão da metrópole e ao mesmo tempo da reafirmação de sua centralidade.

O fato novo, que compreende essa fase atual da urbanização da qual desfrutam intensamente (mas não exclusivamente) a Cidade do Rio de Janeiro e sua aglomeração metropolitana, refere-se a reestruturação da tradicional área metropolitana do Rio de Janeiro, que representa territorialmente a expressão da região urbana fundida na linearidade do eixo centro-periferia. Tanto a configuração territorial quanto a interação dos processos globais de reprodução do atual momento do capitalismo, refazem-se sob as heranças dos processos históricos de evolução urbana e desenvolvimento das atividades econômicas no contexto da urbanização e da industrialização ao longo do século $X X$, subordinando formas e funções arcaicas, mas sem as superar.

Todavia uma coisa ambas as formas urbanas (antiga e nova) têm em comum, tanto a cidade política ou industrial quanto a metrópole contemporânea são ordem, ordenação e poder. Diante de um mais alto patamar do processo de urbanização, a metrópole supera a cidade e supera a si mesma quando ao se manter centro permite a criação de novos centros, ou quando ao se tornar dispersa regula a produção e a valorização dos capitais envolvidos na produção, centralizando o comando e a gestão dos fluxos materiais e imateriais envolvidos nessa produção incluindo a produção do próprio espaço.

Verdadeiramente assistimos à conformação de um fato novo, 
marcado pelo fortalecimento de tendências que intensificam os processos espaciais de concentração e centralização das atividades urbanas e do capital na Metrópole Rio em detrimento de sua aglomeração metropolitana. Isso porque, os processos de concentração e centralização renovaram a função de comando, gestão e controle da Metrópole Rio. Especialmente porque sob a função da metrópole contemporânea repousa a racionalidade da acumulação capitalista, diante da qual o caráter social dos produtos só se manifesta a posteriori, nas trocas comerciais, pois as forças produtivas estão dispersas e os processos de produção não estão coordenados (AGLIETTA, 1986, p. 192). Entretanto, essa integração se dá na concentração e na centralização do capital e do trabalho, pois

"la concentración es la ampliación de la propriedad dentro de
un proceso de valorización" e "la centralizacíon del capital
reagrupa bajo un mismo poder de disposición y de control
ciclos de valorización que pueden permanecer separados
entre sí desde el punto de vista de la producción y
realización de las mercancías" (Ibidem, p. 193).

A concentração permite a ampliação da acumulação e a centralização garante uma alternativa a concorrência, mantendo, por vezes, o produto mas associando diferentes capitais, ampliando o poder de decisão, gestão e comando. Em Michael Aglietta encontramos que

con la centralización de la economía, tal desaparecen innumerables capitales individuales por absorción, mientras que otros son reagrupados por fusión o consolidación. La centralización del capital es, pues, una forma violenta de la competencia. [...]. Pero la centralización del capital tiene un significado más general. Es un efecto del proceso general de desvalorización del capital sobre el fraccionamiento de los capitales; mediante el cual el movimento de la acumulación global encuantra nuevas condiciones para su futuro desarrollo. Por eso la centralización del capital no se limita a determinados campos. [...] las fusiones entre capitales se producen por oleadas en íntima relación con el movimento global de la formación de capital. (AGLIETTA, 1986, p. 195 e 196).

A desconcentração territorial das indústrias fluminenses (ou mesmo - movimento de desindustrialização-reindustrialização) da área metropolitana em direção as áreas de dispersão da atividade produtiva 
não contradizem o circuito de concentração e centralização do capital na Metrópole Rio. Isso por dois motivos específicos: primeiramente, por considerarmos o que foi colocado por Aglietta no que se refere ao movimento de acumulação global, que flexibiliza a produção e o trabalho, mas regula a concorrência e garante a centralização do capital. Em segundo, porque permite que, com a dinamização da economia global através dos serviços de inteligência computacional e a ampliação do aporte tecnológico de distribuição de informação e comando, a direção das forças produtivas possam se alargar para além do seu centro gestor sem qualquer prejuízo a produtividade.

É importante considerar a observação feita por Davidovich em relação ao estado do Rio de Janeiro, afirmando que "as indústrias [...] e outras atividades, que compõem a configuração espacial daquele território, tem sede ou representação principal na cidade do Rio de Janeiro" (DAVIDOVICH, 2001a, p. 328). É o caso, por exemplo, da localização da Associação Brasileira das Empresas de Serviços de Petróleo (ABESPetro), que congrega 51 empresas do ramo, grande parte de capital estrangeiro, com sede na área central da metrópole fluminense.

Isso reforça o que vimos apresentando até aqui. O desenvolvimento das economias de aglomeração e a dispersão das atividades produtivas ao longo dos eixos de circulação do território fluminense tenderam a estreitar a dependência dessas economias em relação à Metrópole Rio em um processo de concentração e centralização do capital. A dispersão das unidades produtivas pelo território não comprometeu a centralidade da metrópole fluminense. Como aponta Lencioni "este espraiamento das atividades foi historicamente proporcionado pela tecnologia, principalmente por aquelas capazes de processar e explorar informações, permitindo unir a descontinuidade espacial do processo de produção" (LENCIONI, 1994, p. 59).

No caso específico da Metrópole Rio, o setor de serviços tem uma particular importância pois uma das maiores demandas do mercado e da 
economia global no que diz respeito ao aparelhamento e suporte à produção se revela pelo setor de serviços, especialmente o de transporte e de telecomunicação. A participação percentual acumulada da metrópole do Rio de Janeiro é de 19,02\% (tabela 1).

Tabela 1 - Rio de Janeiro: Posição ocupada pelos maiores municípios*, em relação ao valor adicionado bruto dos Serviços e participações percentuais relativa e acumulada (2011)

\begin{tabular}{|c|c|c|c|c|c|}
\hline \multirow{2}{*}{ Municípios } & \multicolumn{2}{|c|}{$\begin{array}{l}\text { Posição } \\
\text { ocupada }\end{array}$} & \multirow{2}{*}{$\begin{array}{c}\text { Valor } \\
\text { adicionado } \\
\text { bruto dos } \\
\text { serviços } \\
\text { (1000 R\$) }\end{array}$} & \multicolumn{2}{|c|}{$\begin{array}{c}\text { Participação percentual } \\
(\%)\end{array}$} \\
\hline & Brasil & RJ & & Relativa & Acumulada \\
\hline Rio de Janeiro & 20 & 10 & 140138244 & 5,92 & 19,02 \\
\hline Duque de Caxias & $8^{\circ}$ & 20 & 15805674 & 0,67 & 39,60 \\
\hline Niterói & $16^{\circ}$ & 30 & 9918503 & 0,42 & 45,38 \\
\hline São Gonçalo & 210 & 40 & 9144500 & 0,39 & 47,38 \\
\hline
\end{tabular}

* São Paulo é o município brasileiro com o maior valor adicionado bruto dos serviços, aproximadamente $\mathrm{R} \$ 3,1$ bilhões, e participações percentuais relativa e absoluta de 13,09\%.

Fonte: IBGE, 2011.

Elaboração: Juliana Luquez.

A cidade do Rio de Janeiro tem nesse índice um dos elementos de fortalecimento de sua centralidade e de sua função como centro de comando e gestão, especialmente a partir dos serviços modernos de logística e informação. Como destaca Davidovich "Rio de Janeiro e São Paulo [...] estariam deixando de ser a sede da produção propriamente dita, como sucedeu no auge do processo urbano-industrial, para se posicionarem como centros de controle e gestão e polos de serviços avançados, que atendem aos interesses da grande empresa" (DAVIDOVICH, 1999, p. 6). A autora observa também que

No espaço de extensão da metrópole, o espaço da metropolização, mudanças tem lugar em cidades que buscam aparelhar-se para enfrentar tempos de competitividade crescente, envolvendo, medidas de produtividade e de superação de déficits. Sobressaem 
aquelas que dispõem de melhor infraestrutura e recursos técnicos, inclusive automação, aquelas onde foram adotados contratos flexíveis de trabalho e normas de controle ambiental, constituídas, aliás, em requisito para aprovação de financiamentos concedidos pelo BNDES. Ou seja, são cidades que se capacitam para diminuir custos de produção. Poderiam, hoje, ser definidas, não só como pontos de apoio da metrópole, das empresas nela sediadas, mas como nós de articulação de um contexto que tem em mira a economia da globalização. [...]. No espaço da metropolização de São Paulo, que se estruturou com uma densa rede de estradas, de comunicações e de cidades o suposto é que essa matriz se distribui, de algum modo, entre centros do porte de Campinas, São José dos Campos, Santos ou Sorocaba. Já, no caso do Rio de Janeiro, a matriz tem concentração na metrópole, ou melhor, na cidade central, onde se processam, inclusive, os principais acertos e negociações em torno de projetos e empreendimentos; assim, é na cidade do Rio de Janeiro que se reúnem personagens que tratam da instalação da Peugeot - Citroën no Estado do Rio, desde representantes da empresa e da prefeitura de Porto Real, aos da Telerj, da Embratel, da Rio-Gás e do Porto de Sepetiba, prestadores de serviços de infraestrutura que vão participar do projeto, e ainda os que se referem ao setor financeiro, como o BNDES, o Banco Interatlântico, o Codin e outros. (DAVIDOVICH, 1999, p. 5).

Davidovich ressalta a singularidade histórica do processo de estruturação da Metrópole Rio, sua relação com a conformação de sua região metropolitana e o interior do estado fluminense. A concentração de atividades, pessoas, renda, trabalho e tecnologia na capital fluminense agravou a fragmentação territorial e "traduz a contradição entre a posição urbana sucessivamente acumulada pela cidade do Rio de Janeiro e o isolamento secular mantido em relação à sua interlândia imediata" (DAVIDOVICH, 2001b, p. 69).

Ainda sobre esse aspecto, o economista Sobral, acrescenta que 1) a fragilidade institucional do estado do Rio de Janeiro em planejar uma política metropolitana, 2) a fraca densidade produtiva da periferia metropolitana e 3) o dinamismo econômico apoiado, principalmente, nas atividades de serviços, que vêm se apresentando incapazes de incorporar mão de obra e gerar renda crescente, são os fatores que reforçam os impasses da dinâmica territorial fluminense e a centralização de comando, 
gestão e fluxos na Metrópole Rio (SOBRAL, 2015a). A "crise" se reforça mesmo diante do ciclo recente de grandes investimentos públicos e privados característicos da atual fase de reestruturação do espaço metropolitano do Rio de Janeiro, quais sejam:

- Complexo Siderúrgico do Atlântico (Rio de Janeiro e Itaguaí);

- Complexo Petroquímico do Rio de Janeiro (Itaboraí e São Gonçalo);

- Implantação do Arco Metropolitano do Rio de Janeiro (Itaboraí, Magé, Guapimirim, Duque de Caxias, Nova Iguaçu, Queimados, Japeri, Seropédica e Itaguaí);

- Programa de Modernização e Expansão da Frota (PROMEF), com encomendas de navios petroleiros aos estaleiros da Baía de Guanabara (Rio de Janeiro, Niterói e São Gonçalo)

$\mathrm{Na}$ atual fase da urbanização, gerida pelas determinações contraditórias do capitalismo financeiro, o protagonismo da cidade do Rio mediante as demandas da economia global tem sido um dos desafios para o desenvolvimento das cidades metropolitanas e do entorno da região metropolitana do Rio. Neste sentido, Davidovich sinaliza alterações recentes na estruturação da Região Metropolitana do Rio de Janeiro (RMRJ). Sua tese aponta para uma reestruturação setorizada do espaço. A saber: 
Quadro 1 - RMRJ: reestruturação setorizada do espaço (2018)

\begin{tabular}{|c|l|}
\hline $\begin{array}{c}\text { Primeiro setor de } \\
\text { reestruturação da } \\
\text { RMRJ }\end{array}$ & $\begin{array}{l}\text { Refere-se à cidade do Rio de Janeiro e sua esmagadora } \\
\text { concentração de empreendimentos e iniciativas de } \\
\text { reestruturação socioespacial. Destacando-se, sem precedentes, } \\
\text { a Zona Leste na Cidade, especialmente os bairros da Barra da } \\
\text { Tijuca, Jacarepaguá e Campo Grande. }\end{array}$ \\
\hline $\begin{array}{c}\text { Segundo setor de } \\
\text { reestruturação da } \\
\text { RMRJ }\end{array}$ & $\begin{array}{l}\text { Refere-se ao eixo comandado por Niterói, na porção oriental da } \\
\text { Baía de Guanabara, destacando-se ainda os municípios } \\
\text { metropolitanos de São Gonçalo, Itaboraí e Maricá. }\end{array}$ \\
$\begin{array}{c}\text { Terceiro setor de } \\
\text { reestruturação da } \\
\text { RMRJ }\end{array}$ & $\begin{array}{l}\text { Refere-se a Região da Baixada Fluminense, onde os eixos de } \\
\text { comunicação viária tendem a reforçar as relações já } \\
\text { estabelecidas desta porção do território metropolitano com a } \\
\text { metrópole fluminense. Neste setor estão incluídos os } \\
\text { municípios de Belford Roxo, Duque de Caxias, Guapimirim, } \\
\text { Itaguaí, Japeri, Magé, Mesquita, Nilópolis, Nova Iguaçu, } \\
\text { Paracambi, Queimados, São João de Meriti e Seropédica. }\end{array}$ \\
\hline
\end{tabular}

Elaboração: Juliana Luquez, a partir de Davidovich, 1999.

É importante ressaltar que este contexto de reestruturação tem produzido novos nexos de integração no território fluminense, ou seja, da Região Metropolitana com o seu entorno no interior do estado. Esta é uma consideração importante, pois vai ao encontro de todos as considerações que tecemos até aqui, especialmente no alinhamento da perspectiva interpretativa de compreensão da produção contemporânea do espaço a partir da dinâmica de reestruturação, pela qual o processo de metropolização inaugura os eixos de dispersão, ampliando as relações de reprodução do capital na realização da urbanização e fortalecendo os laços (real e virtual) com a globalização.

O mapa 1 apresenta a aglomeração metropolitana do Rio de Janeiro considerando o território institucionalizado de sua Região Metropolitana, conforme atualização em 2013. Composta por 21 municípios, sendo eles: Rio de Janeiro, Belford Roxo, Cachoeiras de Macacu, Duque de Caxias, Guapimirim, Itaboraí, Itaguaí, Japeri, Magé, Maricá, Mesquita, Nilópolis, Niterói, Nova Iguaçu, Paracambi, Queimados, Rio Bonito, São Gonçalo, São João de Meriti, Seropédica e Tanguá. A maior parte da população fluminense concentra-se na Região Metropolitana do Rio de Janeiro, sendo 
a população total do Estado do Rio 16.369 .178 , sua população metropolitana é de 12.064 .084 , o que equivale a $73,7 \%$ de sua população total. Além da Metrópole Rio, com 6.422.922 habitantes, o destaque está para os municípios de São Gonçalo (1.025.507 habitantes), Duque de Caxias (873.921 habitantes), Nova Iguaçu (804.815 habitantes) e Niterói (494.200 habitantes). ${ }^{20}$

A concentração populacional nesses municípios tem sua razão no processo de industrialização do território fluminense e na consequente transformação do espaço das cidades entre as décadas de 1930 a 1980 consolidando a urbanização no em torno da Baía de Guanabara e expandindo os eixos de dispersão metropolitana para os demais municípios resultando na conurbação das áreas ocupadas na orla ocidental e oriental da Baía de Guanabara (GEIGER, 1956).

${ }^{20}$ Fundação Centro Estadual de Estatísticas, Pesquisas e Formação de Servidores Públicos do Rio de Janeiro (CEPERJ). 
Mapa 1 - Região Metropolitana do Rio de Janeiro: aglomeração e mancha urbanas (2018)

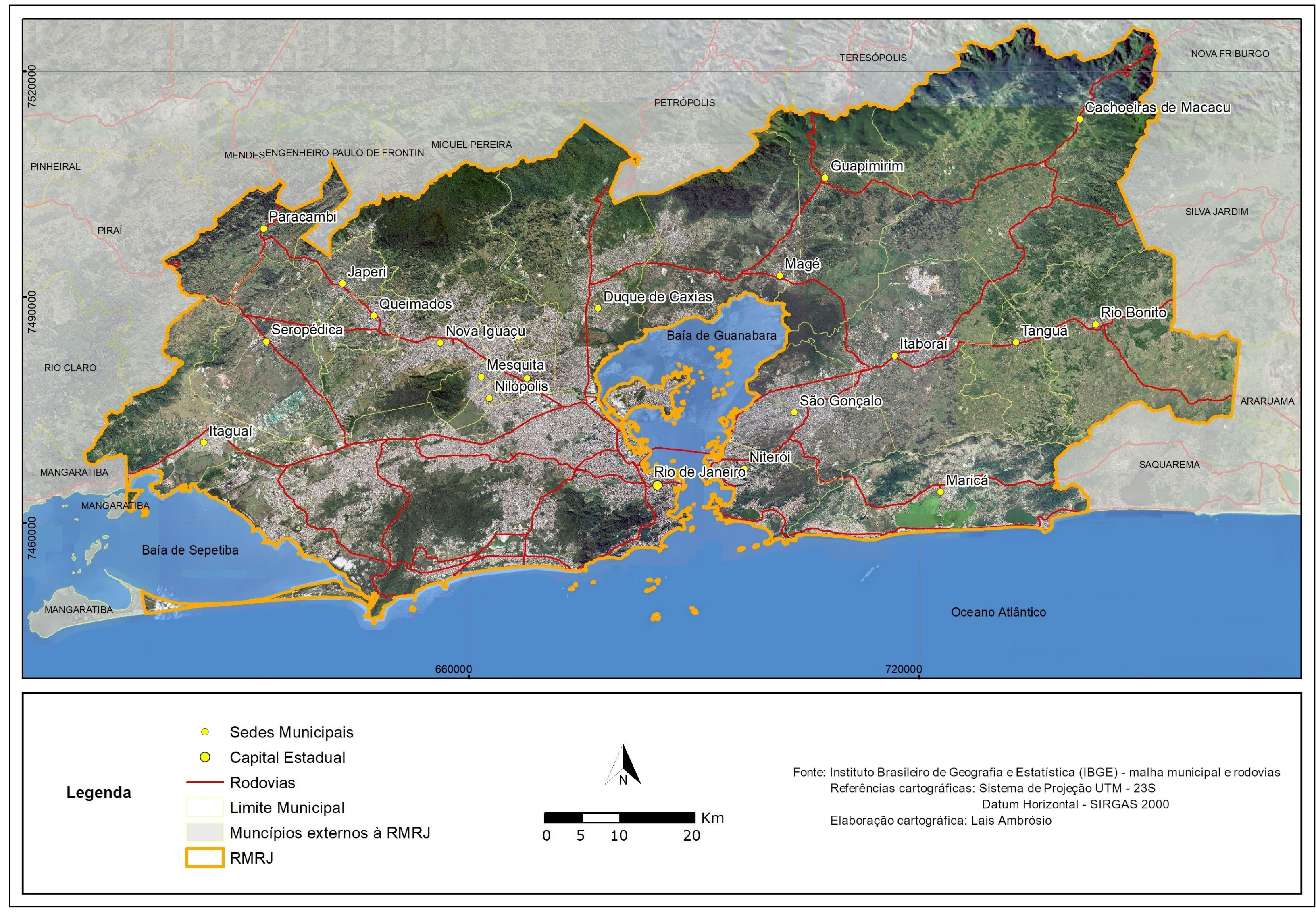


Vemos na aglomeração metropolitana do Rio de Janeiro uma conformação a partir de eixos radiais, inicialmente consolidados na faixa litorânea da orla ocidental da Baía de Guanabara, expandindo a urbanização para os subúrbios contínuos e descontínuos da cidade do Rio de Janeiro, entre os maciços da Tijuca, da Pedra Branca e de Gericinó e a porção leste da Guanabara. A orla oriental da Baía de Guanabara, o maior eixo descontínuo da urbanização fluminense, teve sua consolidação urbana na forma de conurbação entre os territórios de Niterói e São Gonçalo. A industrialização nessa região construiu para si a urbanização que precisava, caracterizada pela instalação de uma forte infraestrutura portuária, ferroviária e bondes, vilas operárias, parques industriais, comércio, escolas operárias, cinemas, etc.

Mendes destaca em seu trabalho a estreita relação que se estabeleceu entre os municípios de São Gonçalo e Niterói. Devido à expansão urbana proporcionada pela conurbação de alguns bairros operários, especialmente, Neves (São Gonçalo) e Barreto (Niterói), o autor as descreve como "cidades gêmeas" e acrescenta que a vida urbana que se desenvolveu em Niterói também se desenvolveu em São Gonçalo mediada pelo processo de industrialização do território fluminense (MENDES, 1950).

A conurbação verificada na aglomeração metropolitana do Rio de Janeiro como forma espacial da reprodução da Metrópole Rio policêntrica, ressalta a dominação de "superposições e justaposições de espaços com tendências à conformação de territórios demarcados que resultam das inclusões produtivas no processo social" (SEABRA, 2003, p. 9). Ora, se considerarmos o urbano como o processo social em curso e em vias de realização, as inclusões produtivas referem-se as centralidades da totalidade da realidade urbana fluminense que passam a compor o espaço das contradições no movimento da reprodução da metrópole. Em outras palavras, vemos erigir na complexidade metropolitana a relação entre dispersão e fragmentação, reforçando a concentração e a centralização da 
Metrópole Rio; todos esses processos característicos da metropolização do espaço fluminense. Para Lencioni

O processo de metropolização do espaço se expressa na intensificação e multiplicidade dos fluxos de pessoas, mercadorias e informações, bem como pelo crescimento do número de cidades conurbadas, onde não se distingue muito bem, na continuidade da área construída, o limite municipal de cada uma delas. E, também, pela expansão territorial do aglomerado metropolitano e pela extensão e densificação territorial da concentração das infraestruturas. (LENCIONI, 2011, p. 136).

O caráter difuso da aglomeração metropolitana do Rio de Janeiro verifica-se a partir da identificação dos eixos de conformação e expansão da urbanização no em torno da Baía de Guanabara (mapa 2). Identificamos 6 (seis) eixos de dispersão e espraiamento da urbanização. Os eixos $A_{1}, B_{1}, C$ e $D$ constituem os territórios de inclusão produtiva do primeiro momento da urbanização fluminense, aqui chamado de urbanoindustrial. Os eixos $A_{2}, B_{2}, E$ e $F$ constituem os territórios de inclusão produtiva do segundo momento da urbanização fluminense, aqui denominado metropolitano-financeiro.

No que se refere ao momento urbano-industrial a urbanização apresenta-se como determinação histórica na constituição da sociedade moderna, este processo corresponde a consolidação do modelo de acumulação capitalista sob as condições gerais de produção da industrialização. A ruptura nas determinações históricas do movimento de urbanização, no qual irrompe o momento metropolitano-financeiro, inaugurando a sociedade pós-industrial ou sociedade urbana, no qual

A metrópole se coloca ao mesmo tempo como uma condição para a reprodução do capital, um meio utilizado para a sua reprodução e, ainda, um produto do próprio capital. Isso, num quadro de profundas alterações na dinâmica do capital imobiliário e financeiro, como estratégias de renovação da reprodução capitalista (LENCIONI, 2011, p. 136).

O caminho da problematização da realidade urbana fluminense, proposto aqui pelas vias da compreensão do movimento de produção e reprodução da metrópole, encontra nas premissas acima o direcionamento 
para a identificação dos eixos de conformação e expansão da urbanização da Região Metropolitana do Rio de Janeiro bem como os nexos desses processos com o da reestruturação do espaço - este último, defendido aqui, como álibi da reprodução do capital no momento recente. 
Mapa 2 - Rio de Janeiro: conformação e expansão da urbanização no em torno da Baía de Guanabara (2018)

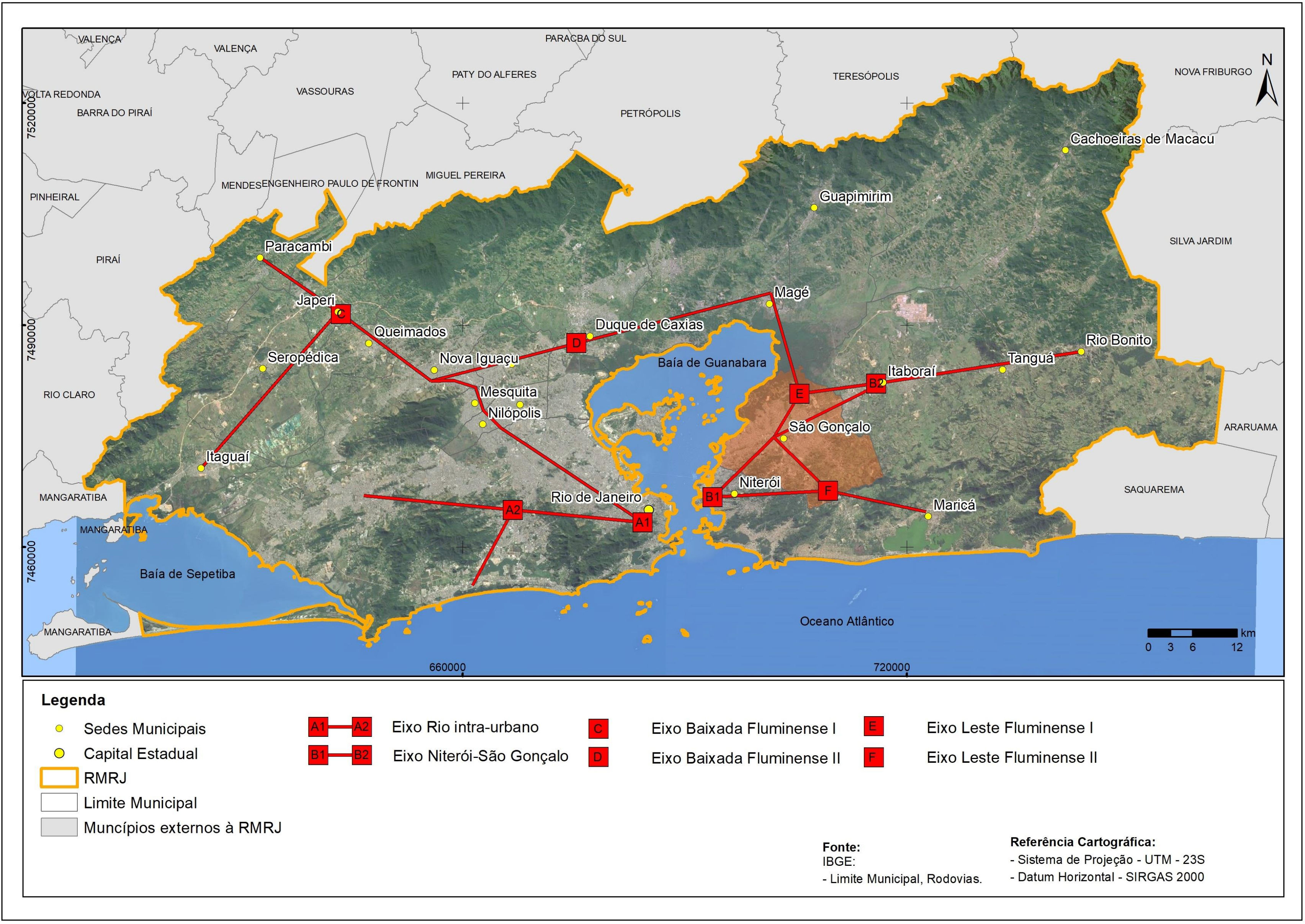


Os eixos $A_{1}, B_{1}, C$ e $D$, embora consolidados na inclusão produtiva do processo social de urbanização, ganham novas dinâmicas frente às estratégias de renovação da reprodução capitalista. Os eixos $A_{2}, B_{2}$, E e $F$ compõem as novas territorialidades do fato urbano, tendo o processo de metropolização sua maior síntese complexa.

Os eixos $A_{1}, B_{1}, C$ e $D$, consolidados sob a lógica de reprodução urbano-industrial, conferiram à Metrópole Rio alto grau de concentração e centralização considerando a articulação metrópole-aglomeração e as atividades urbanas. Ao mesmo tempo que as relações de produção reforçaram a concentração e centralização das atividades urbanas historicamente desenvolvidas na cidade do Rio de Janeiro manifestaram a policentralidade característica da metrópole capitalista na forma espacial da periferização, integrando estreitamente os territórios contíguos de Niterói e São Gonçalo, Nova Iguaçu e Duque de Caxias às lógicas e contradições da reprodução da metrópole, transformando tais municipalidades em complexidades urbanas do ponto de vista das relações de produção, propriedade e trabalho.

Aos eixos $A_{2}, B_{2}, E$ e $F$ atribuímos uma dinâmica especulativa, característica do momento metropolitano-financeiro, fundado na negação da cidade e na valorização do urbano sob a forma espacial da segregação, insere à urbanização sua fase mais complexa e ao mesmo tempo reforça suas continuidades históricas. Os refúgios tidos como seguros, sustentáveis e totalmente integrados à Metrópole Rio, distam algumas poucas dezenas de quilômetros do núcleo metropolitano, porém ligam-se apenas por caminhos rodoviários em sua maioria acessível somente por transporte próprio, o cotidiano passa a se reproduzir na imaterialidade dos fluxos (de dinheiro, de informação) e na materialidade da rede de cabos de fibra óptica que torna possível a penetração das atividades urbanas cada vez mais determinantes da vida cotidiana. As municipalidades de Magé, Guapimirim, Itaboraí, Tanguá, Rio Bonito e Maricá são exemplos dessa nova configuração da urbanização fluminense. 
O espaço assume "uma espécie de realidade própria, da mesma maneira que a mercadoria, o dinheiro, o capital, mas de modo distinto"21 (LEFEBVRE, 2000, p. 35). Considerando a hipótese de Henri Lefebvre sobre o espaço como produto social, vamos em busca do modo distinto como o espaço assume essa realidade autônoma no momento histórico de produção capitalista, e produz assim o espaço, o seu espaço de reprodução.

Segundo Marx

Uma coisa pode ser valor de uso sem ser valor. É esse o caso quando sua utilidade para o homem não é medida pelo trabalho. Assim é o ar, a terra virgem, os campos naturais, a madeira bruta etc. Uma coisa pode ser útil e produto do trabalho humano sem ser mercadoria. Quem, por meio de seu produto, satisfaz sua própria necessidade, cria certamente valor de uso, mas não mercadoria. Para produzir mercadoria, ele tem de produzir não apenas valor de uso, mas valor de uso para outrem, valor de uso social. E não somete para outrem. O camponês medieval produzia a talha para o senhor feudal, o dízimo para o padre, mas nem por isso a talha ou o dízimo se tornavam mercadoria. Para se tornar mercadoria, é preciso que o produto, por meio da troca, seja transferido a outrem, a quem vai servir como valor de uso.\} Por último, nenhuma coisa pode ser valor sem ser objeto de uso. Se ela é inútil, também o é o trabalho nela contido, não conta como trabalho e não cria, por isso, nenhum valor. (MARX, [1867] 2013, p. 118)

O espaço se torna, na fase atual da urbanização contemporânea - a metropolização - o produto com maior valor social agregado e as cidades tornam-se a possibilidade concreta de extração de mais valia e de transferência de valor. Se retornarmos ao mapa 2, veremos que os eixos de conformação e expansão da urbanização fluminense são, em verdade, os eixos de reestruturação do espaço, mas não de todo o espaço e sim de porções do espaço - eis o nexo entre a fragmentação, reestruturação e valorização do espaço. Logo, destacamos a reestruturação do espaço como sendo a possibilidade interpretativa do "modo distinto", ao qual se

${ }^{21}$ Texto original: «l'espace ait pris dans le mode de production atuel et dans la société en acte telle qu'elle est, une sorte de realité propre, au même titre e dans le même processus global que la marchandise, l'argent, le capital, mais de façon distincte » (LEFEBVRE, 2000, p. 35). 
refere Henri Lefebvre em relação a realidade própria do espaço, ou seja, o caráter reestruturante do valor no processo de produção do espaço.

Se considerarmos que a medida do valor é o trabalho, ou melhor, o tempo de trabalho socialmente necessário à produção, estabeleceremos uma relação lógica: quanto mais trabalho requerido para a produção maior o valor do produto. Contudo é importante atentar-nos, no que se refere ao processo de valorização, às diferentes e sucessivas fases do processo de trabalho (MARX, [1867] 2013, p. 264), como consideradas por Karl Marx, para quem há diferentes processos de trabalho que precisam se realizar para produzir o valor de troca (o produto) e que os elementos constitutivos da produção, mesmo que dispersos no tempo e no espaço, determinam sua valorização. Ora, se o espaço é produto social, sua valorização se dá pelos diferentes processos de trabalho requeridos para a sua produção e, por isso, estruturantes no processo global. Mas não só isso. A relação capital-trabalho, sob a problemática do espaço, continua o processo de valorização do espaço, formando, transferindo e extraindo do espaço valor produzido em momento anterior. As novas formas de valorização do espaço não põem fim as anteriores, pois essas estão subordinadas àquelas.

Maricato (2015) nos fornece um exemplo da formulação teórica acima apresentada. Para a autora, a urbanização dos baixos salários, característica das cidades da periferia do capitalismo, é marcada pela construção da moradia como forma de produção doméstica e, na maioria das vezes, ilegal, paulatina e durante os horários de folga do trabalho remunerado. Os trabalhadores recebem pouco pela força de trabalho que vendem e nada pela construção de suas próprias moradias, ao contrário, todo o custo é retirado do seu salário. Essa situação, segundo a autora, é um exemplo não só de uma produção doméstica no contexto urbano, mas também de produção da cidade, de bairros, de cotidiano.

Essa prática (da autoconstrução das casas) contribuiu para a acumulação capitalista durante todo o período de industrialização no Brasil, particularmente de 1940 a 1980, 
quando o país cresceu a taxas aproximadas de $7 \%$ ao ano, e o processo de urbanização cresceu $5 \%$ ao ano (IBGE). À industrialização com baixos salários correspondeu a urbanização com baixos salários. O exemplo revela que uma certa modernização e um certo desenvolvimento (industrialização de capital intensivo, produção de bens duráveis) dependeram de um modo pré-moderno, ou mesmo pré-capitalista (a autoconstrução da casa), de produção de uma parte da cidade. Essa imbricação foi (e ainda é) fundamental para o processo de acumulação capitalista nacional e internacional. (MARICATO, 2015, p. 26).

Mesmo os bairros operários, tradicionalmente populares, compostos por casas autoconstruídas não estão fora do processo de valorização, pois o trabalho requerido para a sua produção somado ao trabalho requerido na construção de infraestrutura urbana (vias de comunicação, equipamentos coletivos, comércio e serviços), ao longo do tempo incorporada, faz parte do processo de produção do espaço e da cidade e, portanto, de sua valorização. Se a classe trabalhadora, em um primeiro momento, produz a cidade como valor de uso, as relações sociais envolvidas no processo de produção - quer na fábrica ou na cidade subordinam a então produção doméstica ao processo de revalorização, pois

Os capitais que ganham com a produção e exploração do espaço urbano agem em função do seu valor de troca. Para eles, a cidade é mercadoria. É um produto resultante de determinadas relações de produção. Se lembrarmos que a terra urbana, ou um pedaço de cidade, constitui sempre uma condição de monopólio - ou seja, não há um trecho ou terreno igual a outro, e sua localização não é reproduzível estamos diante de uma mercadoria especial que tem um atributo de captar ganhos sob a forma de renda. A cidade é um grande negócio e a renda imobiliária, seu motor central. (MARICATO, 2015, p. 23).

Na aglomeração metropolitana do Rio de Janeiro, as áreas urbanas dos municípios de Nova Iguaçu, Duque de Caxias e São Gonçalo, são exemplos da formulação teórica aqui apresentada. O espaço urbano construído nessas municipalidades teve como principal agente produtor, por um lado, a classe operária que se consolidou nos anos 1950, se 
diversificou pós-1960 e se transformou, nas últimas três décadas, em trabalhadores urbanos terciários, terceirizados e informalizados; por outro, os produtores imobiliários, os proprietários fundiários e dos meios de produção e o Estado, articulados, construíram cidades fragmentadas, homogeneizadas e hierarquizadas, cujo caminho da metropolização se faria possível com a concentração das atividades urbanas, a centralização de comando, gestão e fluxos no Metrópole Rio e com a dispersão territorial do fenômeno urbano nas áreas suburbanas e periféricas, para as quais a classe trabalhadora foi sendo assentada e, reproduzindo sua força de trabalho, produziu a regionalização da metrópole fluminense.

Soares (1962), destacou sobre Nova Iguaçu que

Essa grande massa humana, que reside em Nova Iguaçu, se
compõe, na sua grande maioria, de uma população pobre
que aí foi encontrar habitação de módico aluguel ou então
um pequeno lote, de baixo preço, comprado com enorme
facilidade de pagamento, para construir sua modesta
residência. Nova Iguaçu, como todos os subúrbios do Grande
Rio de Janeiro, se caracteriza pelo fato de abrigar,
predominantemente, uma população pouco favorecida de
recursos. (SOARES, 1962, p. 33)

A tabela 2 apresenta Duque de Caxias, Niterói, Nova Iguaçu e São Gonçalo com os maiores números em relação ao pessoal ocupado em atividades industriais na aglomeração metropolitana fluminense, em 1950. À exceção de Niterói, as demais municipalidades destacam-se pelo baixo número de pessoal ocupado no município de residência. O que nos leva a inferir que o processo de periferização da classe trabalhadora metropolitana fluminense inaugura eixos da Metrópole Rio em direção aos lotes de construções populares que uma vez consolidados agregam valor à terra urbana e dinamizaram o processo de valorização das áreas periféricas e suburbanas da metrópole enquanto realizava a dispersão e a fragmentação do território sob domínio da urbanização industrial. 
Tabela 2 - Aglomeração metropolitana fluminense: população e pessoal ocupado no comércio e na indústria (1950)

\begin{tabular}{|c|c|c|c|c|c|}
\hline \multirow[b]{2}{*}{ Município } & \multirow[b]{2}{*}{ População } & \multicolumn{2}{|c|}{ Pessoal ocupado no comércio } & \multicolumn{2}{|c|}{ Pessoal ocupado na indústria } \\
\hline & & $\begin{array}{l}\text { Residentes no } \\
\text { município }\end{array}$ & $\begin{array}{l}\text { Ocupados nos } \\
\text { estabelecimentos } \\
\text { do município }\end{array}$ & $\begin{array}{l}\text { Residentes no } \\
\text { município }\end{array}$ & $\begin{array}{c}\text { Ocupados nos } \\
\text { estabelecimentos do } \\
\text { município }\end{array}$ \\
\hline Cachoeiras de Macacu & 16.272 & 199 & 133 & 271 & 82 \\
\hline Duque de Caxias & 92.459 & 2.468 & 1.166 & 11.811 & 3.287 \\
\hline Itaboraí & 19.472 & 331 & 287 & 990 & 643 \\
\hline Magé & 19.735 & 616 & 349 & 5.740 & 4.623 \\
\hline Nilópolis & 46.406 & 1.874 & 625 & 4.749 & 780 \\
\hline Niterói & 186.309 & 8.374 & 5.416 & 14.218 & 14.638 \\
\hline Nova Iguaçu & 74.290 & 3.696 & 1.330 & 13.808 & 3.216 \\
\hline São Gonçalo & 127.276 & 3.806 & 1.531 & 13.263 & 6.612 \\
\hline São João de Meriti & 76.462 & 2.214 & 838 & 9.854 & 314 \\
\hline
\end{tabular}

Fonte: Censo demográfico, 1950.

Elaboração: Juliana Luquez, a partir de SOARES, 1962. 
Soares (1962) também acrescenta que em 1945, Nova Iguaçu possui 500 construções licenciadas, em 1955 esse número sobe para 1860 $(+26 \%)$. A autora atribui a esse crescimento a abertura da Rodovia Presidente Dutra (trecho da BR-116) que giraria a roda da acumulação da citricultura (atividade econômica típica nos municípios do em torno da Baía de Guanabara) em direção às atividades fundiárias de loteamento e construção de empreendimentos residenciais e industriais na aglomeração metropolitana fluminense 22 . A função dormitório, como se convencionou chamar a dinâmica metropolitana de atração/influência entre um núcleo urbano principal e as cidades do seu em torno, é, em verdade, a consolidação do processo de estruturação urbano-industrial e berço da estruturação metropolitano-financeira.

Alguns bairros de Nova Iguaçu, Duque de Caxias e São Gonçalo destacam-se na dinâmica de revalorização do espaço na aglomeração fluminense, reforçando a fragmentação entre a Metrópole Rio e sua aglomeração metropolitana e realizando a dinâmica da produção do espaço em um movimento que se apreende pelos processos de periferização-espoliação-segregação. A periferização da classe trabalhadora, consolidando-se na expansão da industrial sob um modelo de acumulação contraditório entre o crescimento econômico e a pauperização absoluta ou relativa dos diversos segmentos da classe trabalhadora e aniquilando as formas históricas de apropriação social do espaço, incluindo a vida de bairro (SEABRA, 2003). A espoliação urbana, que vista pelas lentes do problema habitacional, constitui uma dimensão da exploração do trabalho e da exclusão cidadã. A segregação espacial, gestada nas relações sociais de produção e materializada como contradição urbana ${ }^{23}$ no processo de valorização diferencial da terra, que também caracteriza a especulação imobiliária na dinâmica de produção do

22 Sobre esse assunto, tratamos em "Evolução e estruturação urbanas de São Gonçalo: do final do século XIX à segunda guerra mundial", 2013.

${ }^{23}$ Para Kowarick as contradições urbanas se dão em decorrência de os "investimentos públicos em bens de consumo coletivo [serem] tradicionalmente realizados em prejuízo da grande massa dos trabalhadores" (KOWARICK, 2000, p. 23). 
espaço (KOWARICK, 2000).

É flagrante que a maior parte dos investimentos públicos é dirigida para as áreas onde vivem e trabalham as classes abastadas e que 0 processo de revalorização do espaço em áreas populares é uma via do movimento de reestruturação do espaço para maximizar a realização do capital e ampliar as condições gerais necessárias ao processo de acumulação. Por isso insistimos na formulação teórica que considera o processo de valorização como parte da exploração do trabalho e da exclusão cidadã da classe trabalhadora em relação à cidade que ela mesma produz. No caso das áreas urbanas em municipalidades periféricas essa produção da cidade é, por um lado, realizada pelas próprias mãos do trabalhador (residências autoconstruídas, bairros fundados por invasões e loteamentos clandestinos, ofertas populares ao acesso à terra) e, por outro lado, por sua capacidade de pressionar e obter do Estado, por meio de lutas sociais e reivindicações, os elementos indispensáveis à sobrevivência na cidade, estes também indispensáveis a reprodução da força de trabalho.

A engrenagem da reprodução do capital e de suas contradições não só expulsa a classe trabalhadora para longínquas áreas de possibilidades do modo de vida urbano (periferização) no momento da consolidação de uma estrutura de relações contidas na produção do espaço (espoliação), como também é capaz de reorientar o processo de valorização do espaço por meio da renovação das continuidades de seu movimento (segregação). Assim, estrutura-forma-função urbanas ganham um dinamismo no processo de produção do espaço que torna possível a afirmação de que as áreas periféricas ou os espaços populares, ontem produzidos pela classe trabalhadora, são, hoje, álibi de reestruturação do espaço para a sua revalorização, em um momento marcado pela iniciativa do Estado integralmente tomada pelos interesses privados (CHESNAIS, 1996). Outrora, "moradores espoliados e trabalhadores explorados" (KOVARICK, 2000, p. 35); ora, moradores segregados e trabalhadores 
precarizados, lançados à sorte da economia urbana terciária e sob o julgo da financeirização do capital.

Alguns bairros populares da Metrópole Rio, revalorizados na dinâmica imobiliária no contexto dos megaeventos esportivos (Copa do Mundo, em 2014 e Olimpíada, em 2016), como Marechal Hermes $(9,59 \%)$, Cascadura (7,56\%), Lins de Vasconcelos $(6,7 \%)$ e Abolição $(6,28 \%)^{24}$, todos localizados na zona norte carioca, foram ao longo do século XX ganhando estereótipos pejorativos, pois as ocupações consolidaram-se por uma população predominantemente operária. A reprodução da metrópole e a fragmentação do tecido urbano vão redefinir os estereótipos espaciais e consolidar o espaço da classe trabalhadora metropolitana nas áreas urbanas das municipalidades do em torno da Baía de Guanabara sob a influência da Metrópole Rio. Há, porém, de se destacar uma especificidade da metropolização fluminense: a dinâmica metropolitana sob a influência da Cidade do Rio de Janeiro, capital federal de 1889 a 196025; e a dinâmica metropolitana sob a influência da Cidade de Niterói, capital estadual de 1835 a 1893 e de 1903 a 1974. Em 1975, a fusão do Estado da Guanabara, condição político-administrativa do Distrito Federal do Rio de Janeiro desde 1960, com o Estado do Rio de Janeiro, redefiniu e reorganizou os territórios fluminense e carioca, reconfigurando o Estado do Rio de Janeiro em torno da centralização e concentração da Cidade do Rio, a partir de então, a capital fluminense. Contraditoriamente, a fusão não impediu a cisão territorial fluminense e, ao contrário, reforçou-se com ela.

A metropolização fluminense consolidou um espaço fragmentado, homogêneo e hierarquizado. Se a centralização do comando, da gestão e dos fluxos reforçou a posição da Cidade do Rio de Janeiro em relação à

${ }^{24}$ Dados divulgados pelo Sindicato da Habitação (Secovi Rio) e pelo portal imobiliário Viva Real em relação a 2015.

25 A Cidade do Rio de Janeiro foi, sucessivamente, capital da Colônia Portuguesa do Estado do Brasil, de 1621 a 1815, do Reino Unido de Portugal, Brasil e Algarves entre 1815 a 1822, do Império do Brasil, de 1822 a 1889 e da República do Brasil até 1960, quando a sede do governo foi transferida para Brasília. 
sua aglomeração metropolitana pós-fusão, também subordinou aos interesses do capital a reprodução das contradições urbanas no eixo metropolitano sob a influência de Niterói. Um exemplo desse movimento expressa-se na tabela 3.

Tabela 3 - RMRJ: valor do $\mathrm{m}^{2}$ para compra de imóvel residencial considerando os municípios com maior dinâmica imobiliária (2015-2018)

\begin{tabular}{|c|c|c|}
\hline Município & Bairro & Valor médio do $\mathrm{m}^{2}(\mathrm{R} \$)$ \\
\hline \multirow{7}{*}{ Nova Iguaçu } & Centro & 5.545 \\
\hline & Metrópole & 4.376 \\
\hline & Rancho Novo & 4,107 \\
\hline & Caonze & 4.060 \\
\hline & Luz & 3.780 \\
\hline & Prata & 3.313 \\
\hline & Posse & 3.107 \\
\hline \multirow{6}{*}{ Duque de Caxias } & Jardim 25 de Agosto & 5.172 \\
\hline & Engenho do Porto & 4.043 \\
\hline & Centro & 3.855 \\
\hline & Jardim Primavera & 3.404 \\
\hline & Saracuruna & 2.365 \\
\hline & Doutor Laureano & 2.248 \\
\hline \multirow{6}{*}{ São Gonçalo } & Maria Paula & 4.358 \\
\hline & Centro & 4.125 \\
\hline & Barro Vermelho & 4.001 \\
\hline & Alcântara & 3.853 \\
\hline & Neves & 3.688 \\
\hline & Colubandê & 3.323 \\
\hline \multirow{9}{*}{ Rio de Janeiro } & Leblon & 22.346 \\
\hline & Ipanema & 20.218 \\
\hline & Lagoa & 18.039 \\
\hline & Barra da Tijuca & 10.327 \\
\hline & Centro & 8.354 \\
\hline & Méier & 5.483 \\
\hline & Taquara & 4.790 \\
\hline & Madureira & 3.820 \\
\hline & Campo Grande & 3.576 \\
\hline \multirow{8}{*}{ Niterói } & Charitas & 9.165 \\
\hline & Gragoatá & 8.844 \\
\hline & Icaraí & 7.889 \\
\hline & Camboinhas & 7.084 \\
\hline & Santa Rosa & 6.174 \\
\hline & Centro & 5.652 \\
\hline & Barreto & 5.024 \\
\hline & Fonseca & 4.341 \\
\hline
\end{tabular}

Fonte: Secovi Rio e VivaReal

Elaboração: Juliana Luquez. 
Nos territórios municipais do Rio de Janeiro e de Niterói encontramse as áreas mais valorizadas da aglomeração metropolitana fluminense. Nas quais observa-se uma forte e intensa dinâmica especulativa com valores que chegam a ser de 5 (cinco) a 10 (dez) vezes maiores que em outras áreas da região metropolitana. Os empreendimentos imobiliários implantados nos bairros nobres das cidades do Rio de Janeiro e de Niterói são tanto residenciais quanto comerciais respondem à demanda de mercado garantida por uma maior mobilidade social das classes mais abastadas e atendem à dinâmica de centralização e concentração das atividades urbanas nessas localidades.

A atividade imobiliária mantém relação estreita com a dinâmica de produção do espaço na aglomeração metropolitana do Rio de Janeiro, especialmente, a partir dos anos 1930. Até essa época a produção de moradias era uma exclusividade da iniciativa privada. O provimento de habitação pelo poder público, dos anos 1930 em diante, inaugura novos arranjos especulativos da atividade imobiliário. Por exemplo, em São Paulo, a cidade explode em periferias fundadas no trinômio loteamentocasa própria-autoconstrução (BONDUKI, 2013). No Rio de Janeiro, a explosão da cidade em direção aos subúrbios e freguesias rurais, deu-se pelo binômio trem-segregação proletária (FERNANDES, 2011). E, justamente, nesse movimento de expansão urbana, a atividade imobiliária encontrou seu limite e sua superação enquanto forma especulativa de produção do espaço.

Desde as Caixas de Aposentadorias e Pensões (1923) - aos Institutos de Aposentadoria e Pensão (1930-39), passando pela Lei do Inquilinato (1942), pela Fundação da Casa Popular (1946), pela criação do Banco Nacional de Habitação (1964), os mais de 10 anos sem largos investimentos em política habitacional no Brasil - até o Programa Minha Casa Minha Vida (2009), o Estado ganhou um certo protagonismo na questão habitacional e consolidou a atuação de capitais imobiliários na valorização do espaço. Considerando a realidade urbana do Rio de Janeiro, 
se por um lado, produzia-se o espaço ao passo que produzia-se a habitação social, provida pela Estado e circunscrita na cidade do Rio de Janeiro, ao mesmo tempo e em contrapartida, outros espaços também eras produzidos fora da provisão do Estado - isso porque essa habitação social não se destinou, inicialmente, ao atendimento de classes populares e sim à camadas estabilizadas de funcionários dos governos, por exemplo (OLIVEIRA, 2013).

$\mathrm{Na}$ outra ponta da cidade e nos seus arredores se produzia uma periferia urbana, fragmentada, por isso excludente. Em São Gonçalo, na Baixada Fluminense, em algumas localidades de Niterói erguiam-se os bairros feitos pelas próprias mãos dos trabalhadores, da classe operário. São os bairros dos grandes loteamentos, da clandestinidade territorial, sem apoio técnico, a cidade ilegal (MARICATO, 2015). A classe operária se apropria de um território que não era interessante ao capital. No Rio de Janeiro a produção de sua periferia se realiza na sua própria negação - no fundo o que ficou é a "cidade maravilhosa" e quando muito os bairros das classes tradicionais e os bairros boêmios. Mas, e o resto da cidade? Seus conjuntos habitacionais? E as cidades da cidade? Implodiu. Explodiu. A mais recente manifestação espacial dessa implosão/explosão verifica-se nas áreas destinadas a implantação do Programa Minha Casa Minha Vida. ${ }^{26}$

Nos tradicionais territórios do operariado metropolitano, como Nova Iguaçu, Duque de Caxias e São Gonçalo, encontram-se as ofertas que mais dinamizam os eixos da reestruturação do espaço por meio da revalorização de áreas consolidadas pela ocupação da classe trabalhadora e daquela pequena parcela que emergiu dessa, os profissionais liberais e pequenos empreendedores. Os empreendimentos destinados à dinâmica imobiliária nessas áreas urbanas estão predominantemente ligados ao

\footnotetext{
${ }^{26}$ Nossa pesquisa não comprometeu-se com um mergulho profundo no tema habitação e produção das cidades, mas reconhece a importância das análises desenvolvidas nesse campo de pesquisa e orientou-se criticamente a partir das análises realizadas pelo Observatório das Metrópoles.
} 
Programa Minha Casa Minha Vida, porém não somente os da Faixa 1, ofertados às famílias com renda de até $R \$ 1.600$ e que são as que enfrentam as maiores dificuldades para conseguir uma moradia adequada e, por isso, compõem o maior percentual das necessidades habitacionais do país. Esses empreendimentos são destinados às Faixas ${ }^{27} 1,5,2$ e 3, que atendem a uma parcela da classe da trabalhadora mais estável (como os funcionários públicos) e uma parcela modesta da "baixa burguesia" (como os empreendedores), pois os beneficiários potenciais devem comprovar que são capazes de suportar o pagamento de um crédito bancário (imagens 3, 4 e 5), o que implica não ter restrições no Serviço de Proteção ao Crédito (SPC) e dispor de renda acumulada em forma de Fundo de Garantia do Tempo de Serviço (FGTS).

\footnotetext{
27 A atual fase do programa habitacional do governo federal, Minha Casa Minha Vida 3, compõe-se de quatro faixas de renda. A Faixa 1 , destina-se as famílias com limite de renda de até $R \$ 1.800$, cujo valor máximo do imóvel seja de até $R \$ 96$ mil e o valor máximo do subsídio de até $\mathrm{R} \$ 86,4$ mil. A Faixa 1,5 atende famílias com limite de renda de até $R \$ 2.600$, cujo valor máximo do imóvel seja de até $R \$ 135$ mil e o valor máximo do subsídio de até 47,5 mil. A Faixa 2 destina-se as famílias com limite de renda de até $\mathrm{R} \$ 4.000$, cujo valor máximo do imóvel seja de até $\mathrm{R} \$ 225$ mil e o valor máximo do subsídio de até $R \$ 29$ mil. A Faixa 3 atende famílias com limite de renda de até $R \$ 7.000$, com valor máximo do imóvel de até $\mathrm{R} \$ 225$ mil e nenhum subsídio. (CAIXA ECONÔMICA FEDERAL).
} 
Imagem 3 - São Gonçalo: Ekos Monjolos Residencial, vendas para as faixas 1 e 1,5 do Programa Minha Casa Minha Vida. Localizado no bairro Monjolos, distante 21,4 km do centro da cidade; 24,1 de Niterói; 41,9km do Rio de Janeiro (2018)

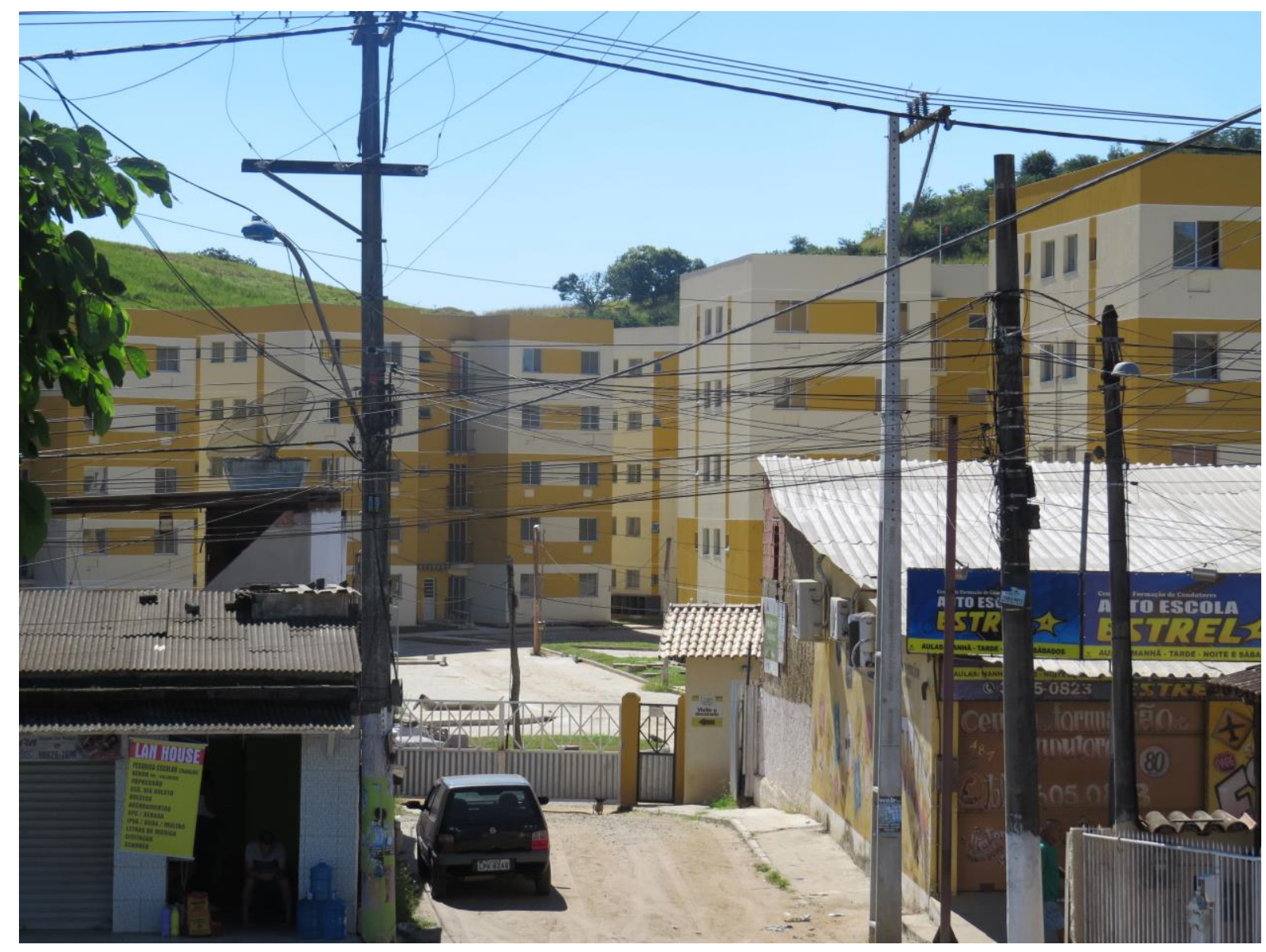

Crédito: Juliana Luquez. 
Imagem 4 - São Gonçalo: Residencial Bela Vista, vendas para as faixas 2 e 3 do Programa Minha Casa Minha Vida. Localizado no bairro operário Neves, distante $5,8 \mathrm{~km}$ do centro da cidade; 4,6 km de Niterói; $22,3 \mathrm{~km}$ do Rio de Janeiro (2018)

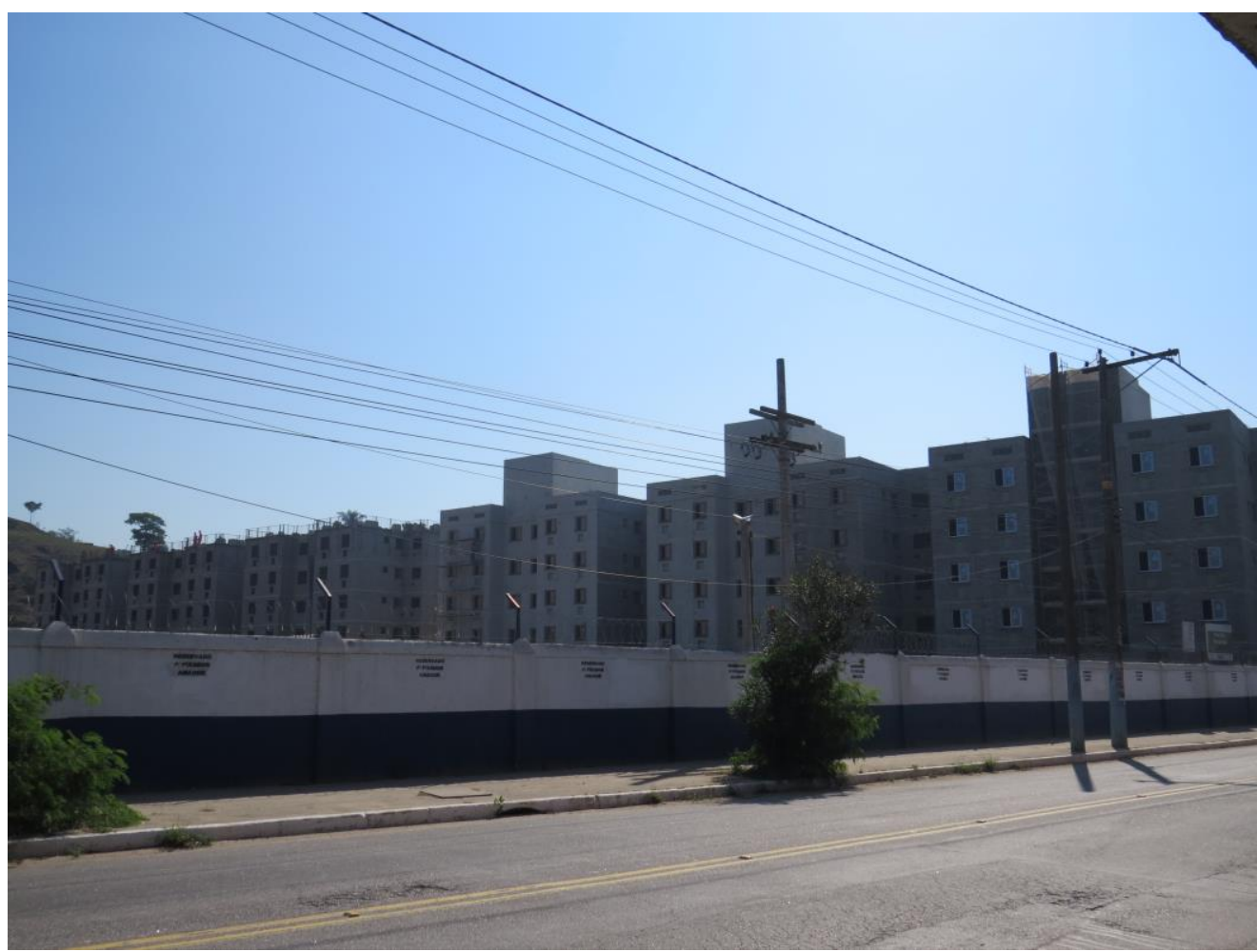

Crédito: Juliana Luquez.
Imagem 5 - São Gonçalo: Residencial Imigrantes, vendas exclusivas para servidores das forças armadas e forças auxiliares. Localizado no bairro operário Vila Lage distante $4,3 \mathrm{~km}$ do centro da cidade; $7,1 \mathrm{~km}$ de Niterói; 24,8 Km do Rio de Janeiro (2018)

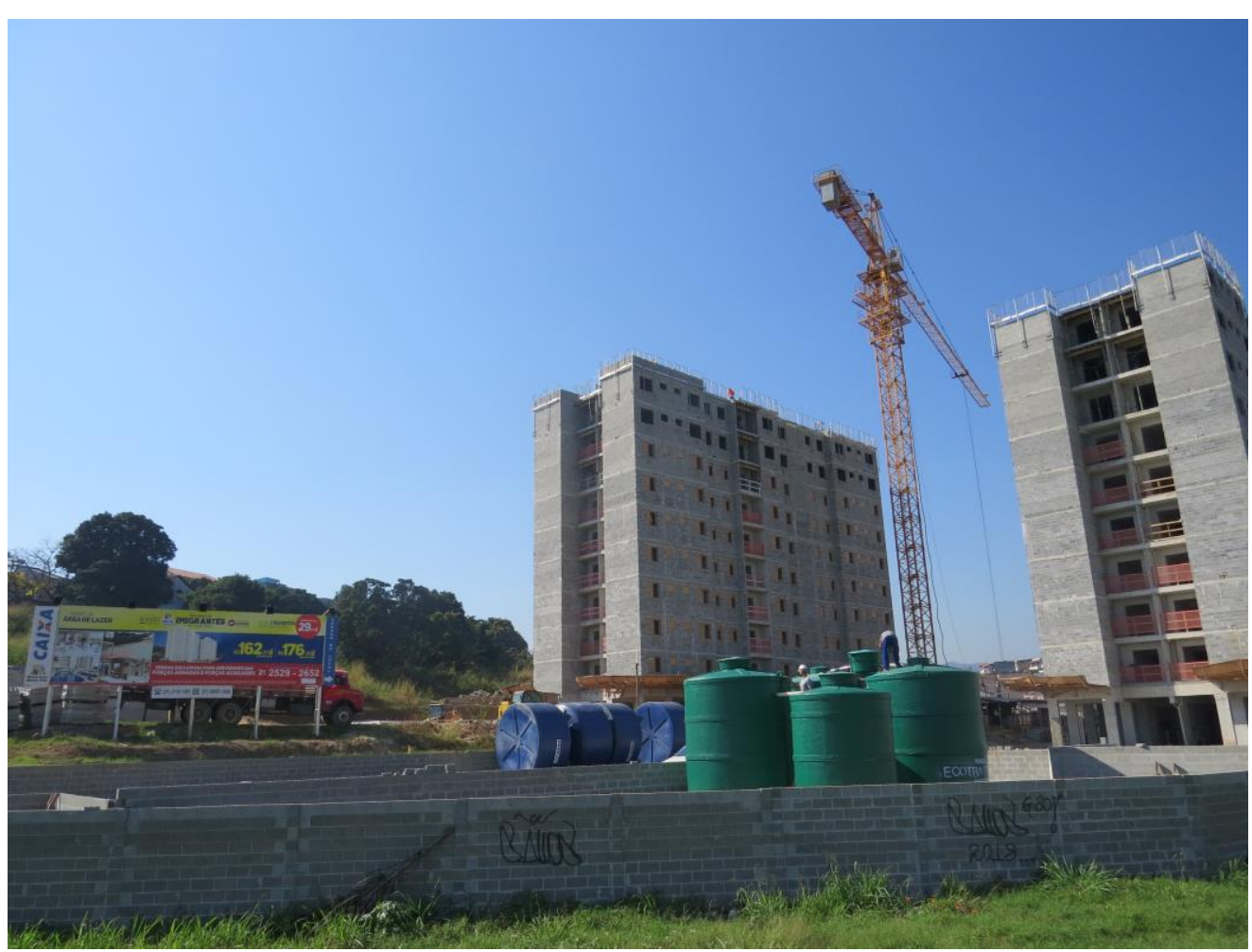

Crédito: Juliana Luquez. 
A periferização da classe trabalhadora se reforça com a difusão do modo de vida urbano na aglomeração fluminense onde poucos serviços coletivos estão à disposição de suas demandas, a espoliação urbana se amplia pelos raios dessa difusão e a segregação se manifesta via reestruturação do espaço no processo de valorização dos fragmentos da cidade. Os trabalhadores com renda mais baixa, com nenhuma ou pouca garantia de crédito para o financiamento de sua moradia, sem recursos à mobilidade urbana, são lançados cada vez mais para longe de áreas urbanas consolidadas e reinseridos na dinâmica de produção do espaço.

Ao mesmo tempo que a urbanização fluminense criou caminhos a partir de dois eixos de expansão das atividades urbanas, complexificou os nós das relações sociais contidas no espaço de consolidação da metropolização: entre os interesses das classes dominantes que detém os meios de produção e as políticas de influência de atração de investimentos públicos e privados e a produção de uma área metropolitana para assentar a classe trabalhadora necessária ao movimento de realização do capital - movimento este, combinando o caráter periférico, espoliador e segregador do atual modo de produção.

A reestruturação do espaço no período contemporâneo de sua produção, embora manifesta por uma ruptura da renovação da reprodução do capital, subordina elementos anteriores de valorização ao atual e reinicie o ciclo de valorização/revalorização perceptível pelo movimento de estruturação/reestruturação - eis os nexos entre as rupturas e as continuidades, ou, seguindo a perspectiva interpretativa de Oliveira (2011), eis a lógica onitorrinquica da produção do espaço. A transição da estruturação urbano-industrial para a metropolitanofinanceira foi possível pela reestruturação do espaço, mas de porções do espaço. Reforçando a fragmentação sem superar as continuidades: periferização, espoliação e segregação a partir das quais a metrópole fluminense se reproduz.

As generalizações e as particularidades do desenvolvimento do 
capitalismo inauguraram a orientação e a crítica sobre o planejamento urbano no Brasil, o qual alinhou-se ao projeto de crescimento econômico sob as bases da industrialização, especialmente a partir dos anos 1930, imprimindo o modelo rodoviário como estruturante no processo de produção do espaço urbano. As alianças criadas nesse contexto fundiram interesses entre os setores públicos e privados estabelecendo políticas urbanas que privilegiassem o transporte rodoviário e individual, favorecessem a concentração industrial, econômica e populacional nas grandes cidades, reforçassem as desigualdades regionais enquanto canalizavam investimentos em projetos de envergadura exclusivamente econômica.

A estruturação urbano-industrial introduziu as contradições múltiplas, oriundas ou não neste tempo histórico, nas relações de produção. A urbanização torna-se a forma espacial dessas relações de produção. Esse modelo de urbanização, planejado e orientado para o crescimento econômico e não para o desenvolvimento social teve, com a instauração do Regime Militar (1964-1985), o aprofundamento de seu desgaste e nenhuma marca de sua superação.

No caso do Rio de Janeiro quando, em 1975, criou-se a Fundação para o Desenvolvimento da Região Metropolitana do Rio de Janeiro $\left(\right.$ FUNDREM) ${ }^{28}$, sob a supervisão da Secretaria de Planejamento e Coordenação Geral do Estado, viu-se o primeiro marco institucional que reconhecia uma questão urbana fluminense. Mas não como caminho da

${ }^{28}$ Com as seguintes finalidades: A) execução de tarefas relacionadas com a elaboração e atualização do Plano de Desenvolvimento Integrado da Região Metropolitana do Rio de Janeiro, com a programação e execução dos serviços comuns e com a coordenação da execução de programas e projetos de interesse da mesma região, através de convênios ou contratos, que Ihe forem delegados pelo Conselho Deliberativo; B) coordenação de programas e projetos de interesse dos Municípios da Região Metropolitana do Rio de janeiro, não relacionados como serviços comuns, quando autorizada pelo Conselho Deliberativo; C) prestação de apoio técnico e administrativo ao Conselho Deliberativo da Região Metropolitana do Rio de Janeiro e assistência técnica aos Municípios no exame de assuntos de interesse da Região Metropolitana do Rio de Janeiro; D) elaboração de estudos, pesquisas e projetos exigidos para o equacionamento de problemas da região Metropolitana do Rio de Janeiro. (DECRETO-LEI ESTADUAL no 14, 15/03/1975) 
superação de uma estrutura espoliadora, periférica e segregadora, mas sim como instrumento dos ditames autoritários do planejamento para ampliar as funções urbanas com vista ao fortalecimento das estratégias de reprodução do capital apoiadas na forma de um estado centralizador. Extinta em 1989, a FUNDREM nunca se consolidou como ente público de integração e articulação metropolitano.

Para Dominguez o contexto político de criação e atuação da FUNDREM concebia o planejamento como forma de controle territorial e institucional (DOMINGUEZ, 2014, p. 318). Se por um lado o período de instalação do II Plano Nacional de Desenvolvimento (II PND), liderado pelo então presidente Ernesto Geisel (1974-1979), que tinha como base a aliança com o governador do estado do Rio, Faria Lima, era transformar o Rio de Janeiro no segundo polo industrial do Brasil, por meio de uma política econômica de descentralização da atividade industrial; por outro lado a centralização política no poder executivo e a subordinação do planejamento em todos as esferas comprometido com o crescimento econômico, fazendo com que a visão racionalista da administração pública torna-se implacável diante das carências e deficiências de infraestrutura e de atendimento às demandas sociais urbanas (CANO, 2011, p. 132).

Esse é o momento no qual a forma urbana ganha o caráter metropolitano, materializando-se espacialmente pelos moldes do autoritarismo do estado capitalista. Para Cano a política de descentralização industrial, a vanguarda desse estado autoritário, no que tange as questões sociais urbanas, "foi, em grande medida, uma política e uma atitude de não enfrentamento dos verdadeiros problemas" (CANO, 2011, p. 136). Dessa forma, aceleram-se os caminhos para a urbanização e descentraliza-se a aparência caótica e insuportável da metrópole, reproduzem-se as contradições e ampliam-se os territórios de seus domínios. 


\subsection{1. "Crise urbana": uma advertência preambular}

O ideário desenvolvimentista presente por mais de 4 (quatro) décadas nos planos, projetos e programas de governos, os quais transformaram as cidades e os rumos da urbanização radicalmente, foi dando lugar a redemocratização que, simultaneamente, foi cooptada pelos ideais neoliberais dos anos 1980 e 1990. Explosão urbana, desordem urbana, crise urbana. A estruturação urbano-industrial anunciava sua negação enquanto gestava as condições de sua transição.

A falácia da crise urbana alastra-se pelas cidades sob a forma de discurso tanto na gestão quanto nas resistências - resistências essas fortalecidas nos anos de chumbo e estarrecidas na redemocratização neoliberal (MARICATO, 2011). As lutas sociais revestem-se de um simbolismo urbano que é quase possível pensar que o caráter econômico da luta de classe por melhores condições de produção foi resignificado pelo caráter político por melhores condições de existência na cidade. Para compreender as generalizações e normalizações do modo de vida urbano é preciso, no dizer de Henri Lefebvre, compreender "o estado crítico com suas implicações não explicitadas" (LEFEBVRE, 2009, p. 141). Para Lefebvre

O estado crítico não provém nem do econômico tomado à parte, nem do político isolado a título de instância. Esse estado crítico tem seu ponto de partida no social como tal: o que Hegel e Marx nomeiam de sociedade civil. A crise no sentido usual iria do econômico ao político. O estado crítico tem sua origem e, sobretudo, seus efeitos não nas organizações ou instituições, mas nas relações que sustentam essas instituições: a família, a escola, as relações entre as pessoas, os "valores", as "normas", as "ideologias". Esmagada, encurralada entre o político e o econômico, essa vasta região sofre de um mal crônico. (LEFEBVRE, 2009, p. 145).

O autor ainda acrescenta

Em suma, a crise é utilizada, prática e ideologicamente, portanto politicamente. O que é necessário denunciar hoje não é somente a subestimação da crise, mas também e 
sobretudo sua utilização para ocultar o estado crítico. [...]. A utilização da crise para negar o estado crítico vai longe. Nesta negação são por vezes cúmplices a direita e a esquerda políticas: cúmplices na manutenção do Estado, na reprodução das instituições estatais e da hierarquia. Limitando a crise e a luta dita de classes ao econômico, ou seja, às reivindicações concernentes à produção (portanto ao quantitativo), paralisa-se o desdobramento de uma luta que engloba a luta de classes e a amplifica. (LEFEBVRE, 2009, p. 146-147).

Considerando a crítica de Henri Lefebvre acerca dos prenúncios de crises, dentre as quais destacamos a chamada crise urbana, "se sempre convém analisar a crise (descrever fenômenos, captas informações e dados), é preciso igualmente considerar essa mesma crise como analisadora [reveladora] do mundo atual" (LEFEBVRE, 2009, p. 144). Essa inversão metodológica romperia com o caráter analítico de fatos econômicos e inauguraria o caminho do possível: uma crise total (econômica, social, política, cultural) que ameaçasse o Estado e que abalasse o conjunto das relações sociais, ambos solapados em suas estruturas, formas e funções, pois em que pese a manutenção de um dos pilares de sua reprodução, todo o resto está garantido.

A polissemia do termo crise só pode ser considerado sob modificações metodológicas capazes de transformar o horizonte da vida social e o caminho do pensamento, caso contrário, estaríamos fazendo análises sistemáticas e não sintomáticas.

Maricato (2015) nos fornece dois elementos "Para entender a crise urbana"29, a habitação que funda a problemática urbana no Brasil industrial e a mobilidade que funda a problemática metropolitana no Brasil pós-industrialização. Esses dois elementos se dissolvem na análise da crise urbana vivenciadas nas cidades brasileiras, especialmente nos espaços sob o domínio da metropolização, pois materializam a urbanização difusa e a fragmentação do espaço urbano.

Para apresentar uma problematização da realidade metropolitana

${ }^{29}$ Em seu livro homônimo. 
fluminense vimos, então, a necessidade de examiná-la no movimento de estruturação ${ }^{30}$ e reestruturação dos espaços da urbanização. No contexto da aglomeração metropolitana do Rio de Janeiro, nosso olhar repousa sobre São Gonçalo e nossa análise apreende, a partir de suas fases de reestruturação, os momentos da produção do espaço urbano no Rio de Janeiro.

30 Consideramos importante um adendo sobre o uso do termo estruturação. O termo estruturação é tomado aqui como forma-conteúdo a partir da qual o espaço expressa-se como realidade autônoma (LEFEBVRE, 2000) e não como expressão da estrutura social como sugere Manuel Castells (2014). Dessa forma o espaço é um produto social e contém as relações sociais de produção e reprodução e não uma forma social estruturada. Ao analisarmos os argumentos de Manuel Castells sobre a teoria do espaço e os argumentos de Henri Lefebvre sobre a produção do espaço vimos a possibilidade de considerar um sentido à estrutura do espaço e outro à estruturação do espaço. A estrutura do espaço evoca um rebatimento da estrutura social à estrutura espacial, logo um movimento interno com articulações e combinações contraditórias; mas encerrado em um modelo sistêmico como expressão das práticas sociais. A estruturação do espaço possibilita a compreensão do movimento das transformações espaciais ao problematizalo como realidade própria, produto social, discernível e configurado, logo tridimensionado: prática espacial, representações do espaço e espaços de representações (LEFEBVRE, 2000, p. 42). Em suma, na perspectiva lefebvriana a sociedade produz o espaço e toma forma apresentando-se e representando-se nessa criação, mesmo que não coincida com seu espaço, pois este é, ao mesmo tempo sua tumba e seu berço (LEFEBVRE, 2000, p. 43). Na perspectiva castelliana, o espaço é uma forma social particular resultado da articulação de outras formas e processos históricos, logo o espaço é uma organização social expressa espacialmente (CASTELLS, 2014, p. 192). 


\subsection{Um olhar a partir de São Gonçalo}

Para extrair a problemática urbana da crise urbana do Rio de Janeiro escolhemos começar pela crítica à segunda e retornar à primeira. Para isso, seguimos a direção das seguintes questões: como as pessoas vivem e se utilizam do espaço urbano e, dessa forma, como elas o apreendem? Quais problemas mais afetam a reprodução da vida na cidade? Quais as urgências mais aclamadas diante da degradação das condições urbanas? Como a sociedade percebe a cidade no âmbito de suas transformações? Se vivemos uma crise urbana, quais as raízes e fatores de desencadeamento dessa crise? Qual o caminho viável para buscar soluções a ela, visto o contexto de desesperança dos movimentos sociais e desprestígio das lideranças políticas?

Afim de produzirmos uma amostragem ${ }^{31}$ para analisar a crise urbana do Rio de Janeiro a partir de São Gonçalo, realizamos a aplicação de um questionário à população que habita e se utiliza dessa cidade para realizar suas relações. Os gráficos 1,2 e 3 apresentam o perfil socioeconômico dos respondentes e contribuem para a reflexão crítica das questões acima apresentadas.

No que se refere a identidade de gênero (gráfico 1), o predomínio do gênero feminino (60\%) reforça a inclusão precária das mulheres na reprodução da vida urbana, pois seja na inserção no mundo do trabalho, nos deslocamentos intra e interurbanos, nas perturbações cotidianas ou nas esperanças coletivas, foram de suas aflições na cidade que emergiram a maioria dos problemas a seguir apresentados. Dos portadores de necessidades especiais (gráfico 2), todos declaram-se desempregados e

\footnotetext{
31 Essa amostragem contou com 184 respondentes entre 14 e 77 anos. Foi realizada entre os meses de fevereiro e maio de 2018 nas adjacências dos bairros Centro, Neves e Alcântara (Anexo I). Tentamos contato com a Câmara Metropolitana do Rio de Janeiro, mas não obtivemos retorno favorável, até a data de finalização desse trabalho, sobre nossa intenção de entrevista ao ente competente pela integração governamental da Região Metropolitana do Rio de Janeiro. O roteiro de entrevista foi apresentado, mas o representante da Câmara Metropolitana de Integração Governamental do Rio de Janeiro não nos oportunizou respostas (Anexo II).
} 
imóveis não em suas deficiências, mas em suas possibilidades de apropriação e reprodução da/na cidade.

São Gonçalo: perfil socioeconômico dos respondentes (2018)

Gráfico 1 - Identidade de Gênero

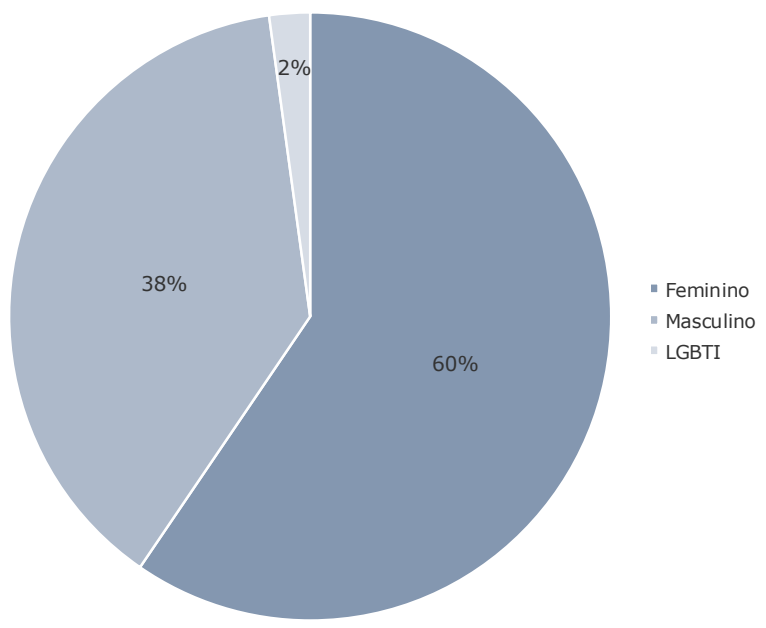

Gráfico 2 - Portadores de Necessidades Especiais (PNE)

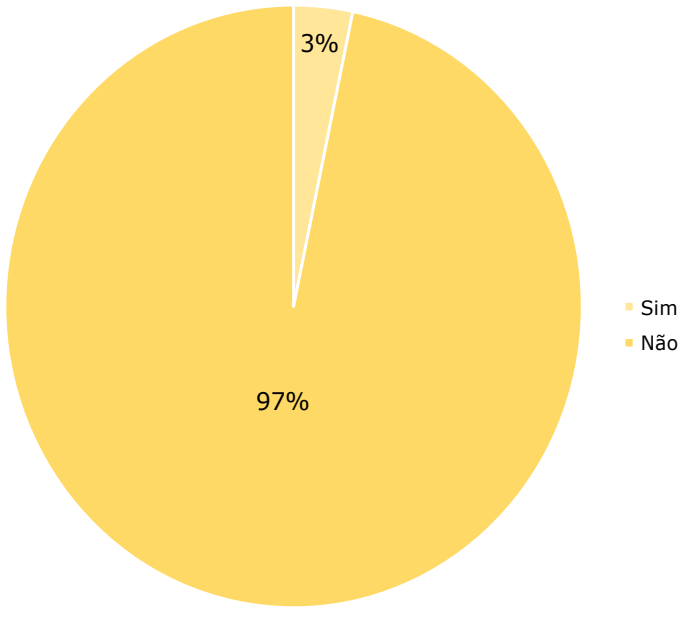

Gráfico 3 - Renda per capita

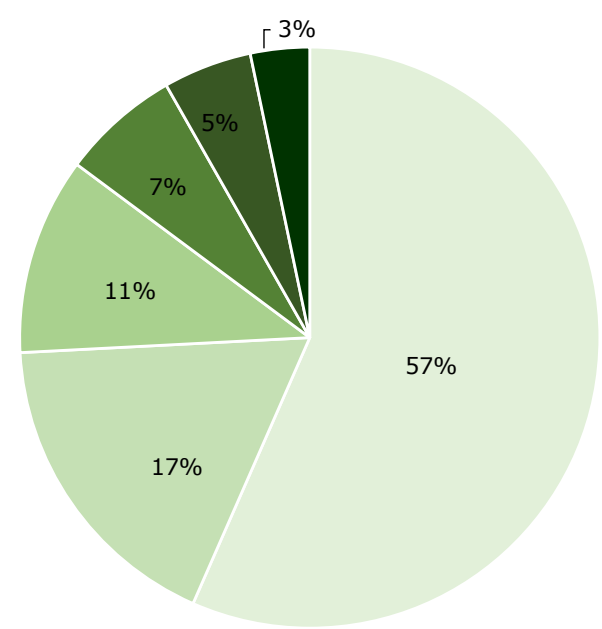

Sem renda ou desempregado

Até 1.000

- De 1.000 a 2.000

- De 2.000 a 3.000

- De 3.000 a 5.000

- Acima de 5.000

Fonte: Dados obtidos por meio de amostragem (2018) Elaboração: Juliana Luquez.

O gráfico 3 revela a face mais degradante da vida na cidade de espaços fragmentos, hierarquizados e homogeneizados pelos processos socioespaciais sob determinações da acumulação do capital: a periferização, a espoliação e a segregação (processos esses que serão ainda aprofundados nesse trabalho). Materializados na paisagem urbana da cidade de São Gonçalo, desigualdade de renda e o acesso às 
oportunidades, é a vertente mais cruel e emblemática da crise do Rio, na qual a população jovem se apresenta mais desenganada. Dos respondentes, 57\% declara não possuir renda ou estar desempregado e dos $43 \%$ dos respondentes que possui algum tipo de renda, $17 \%$ ganha até $R \$ 1.000$. Essa situação concreta é um exemplo daquilo que Maricato (2015) chama de urbanização dos baixos salários, ou seja, a dimensão da produção do espaço urbano a partir da exploração do trabalho no nível da cidade - nível esse considerado por Lefebvre de misto, mediador ou intermediário (LEFEBVRE, 2008).

Essa urbanização também tem um nível global e privado. No nível global, essa urbanização é concebida arbitrariamente a partir de políticas neoliberais como pseudo-representatividade coletiva, manifesta pelo Estado, e que contribui para transformar as estratégias de classe em estratégias políticas e essas em políticas do espaço (LEFEBVRE, 2008). Esse nível global é o nível das relações gerais e, por isso, o nível onde se os interesses do mercado (de capitais, de produtos e de trabalho) são gestados e legitimados. A precarização do trabalho e da condição de vida na cidade é, potencialmente, o maior efeito da reprodução das estratégias do nível global para o nível intermediário (a cidade) ${ }^{32}$.

Já o nível privado é o domínio do edificado, da moradia, da sua relação consigo mesmo (LEFEBVRE, 2008). Esse nível, encontra-se, no processo de urbanização que produziu a cidade moderna sob determinações históricas, afugentado e reprimido. Portanto, subordinado às modulações inorgânicas da vida social, capturado por processos incentivados pelo nível global e necessários à reprodução da acumulação do capital enquanto determinação das relações sociais. Nesse nível a

\footnotetext{
32 Fazendo eclodir, na última década, para as ruas de diferentes pontos do planeta vibrantes insurgências, como a Primavera Árabe, entre 2010 e 2012; as ocupações e manifestações em Nova Iorque, em 2011; os protestos, manifestações e euforias em escala nacional nas cidades brasileiras, em 2013, tendo em comum o caráter urbano das reivindicações, não apenas no que se refere aos locais de onde emergiram as insurgências, mas, especialmente, no que se refere ao ponto de partida das reflexões geradas a partir das pautas apresentadas por esses movimentos.
} 
reprodução da vida acontece, mas também a reprodução da força de trabalho e uma dimensão da exploração também ali se realiza: a informalidade, a autonomia e a ilegalidade das atividades urbanas: salões de beleza e estética em ambientes anexos ou nas áreas externas das dependências domésticas; oficinas; pensões e restaurantes sem registro, garagens e terraços transformados em salões de festa, etc. ${ }^{33}$

A urbanização dos baixos salários manifesta-se em São Gonçalo não só na renda per capita de sua população, como também na arrecadação de sua prefeitura. Essa realidade socioeconômica verifica-se na renda municipal de São Gonçalo que, segundo o anuário de Finanças dos Municípios Fluminenses (2015) ocupa o 70 lugar no ranking estadual do valor absoluto de receita, entretanto, é o último (920) no ranking do estado do Rio de Janeiro a ter sua renda municipal adicionada da renda per capita (mapa 3).

Para Cano, desse âmbito, um confronto se instaura entre os "de cima" e os "de baixo". Para o autor

Os "de baixo não têm como - senão parcial e esporadicamente, privatizar 0 atendimento de suas necessidades. São obrigados a residir nas periferias das cidades, com precária infraestrutura, falta de saneamento básico e débil serviços de transportes. Dependem da escola e da saúde públicas. Por residirem na periferia [...] e pelos seus baixos níveis de renda, é naturalmente reduzida sua capacidade de contribuir para a administração pública municipal, embora exerçam forte pressão por atendimento às suas carências sociais básicas. Deste último confronto, a contradição emerge com virulência: agrava-se o problema distributivo urbano, pois os 'de cima' pagam mais para receber mais e melhor, enquanto os 'de baixo', por não poderem pagar, recebem precário atendimento público, em face do agravamento das finanças públicas municipais, que precisam gastar, mas pouco arrecadam. A esse resultado chamei de 'arrebentação' do padrão urbano. (CANO, 2011, p. 137).

${ }^{33}$ Santos (2008), em seu livro "O espaço divido: os dois circuitos da economia urbana dos países subdesenvolvidos", o autor abordou esse tema e o consagrou como importante área de estudo na Geografia através da teoria dos circuitos da economia urbana. 
Mapa 3 - Rio de Janeiro: ranking da receita per capita dos municípios (2014)

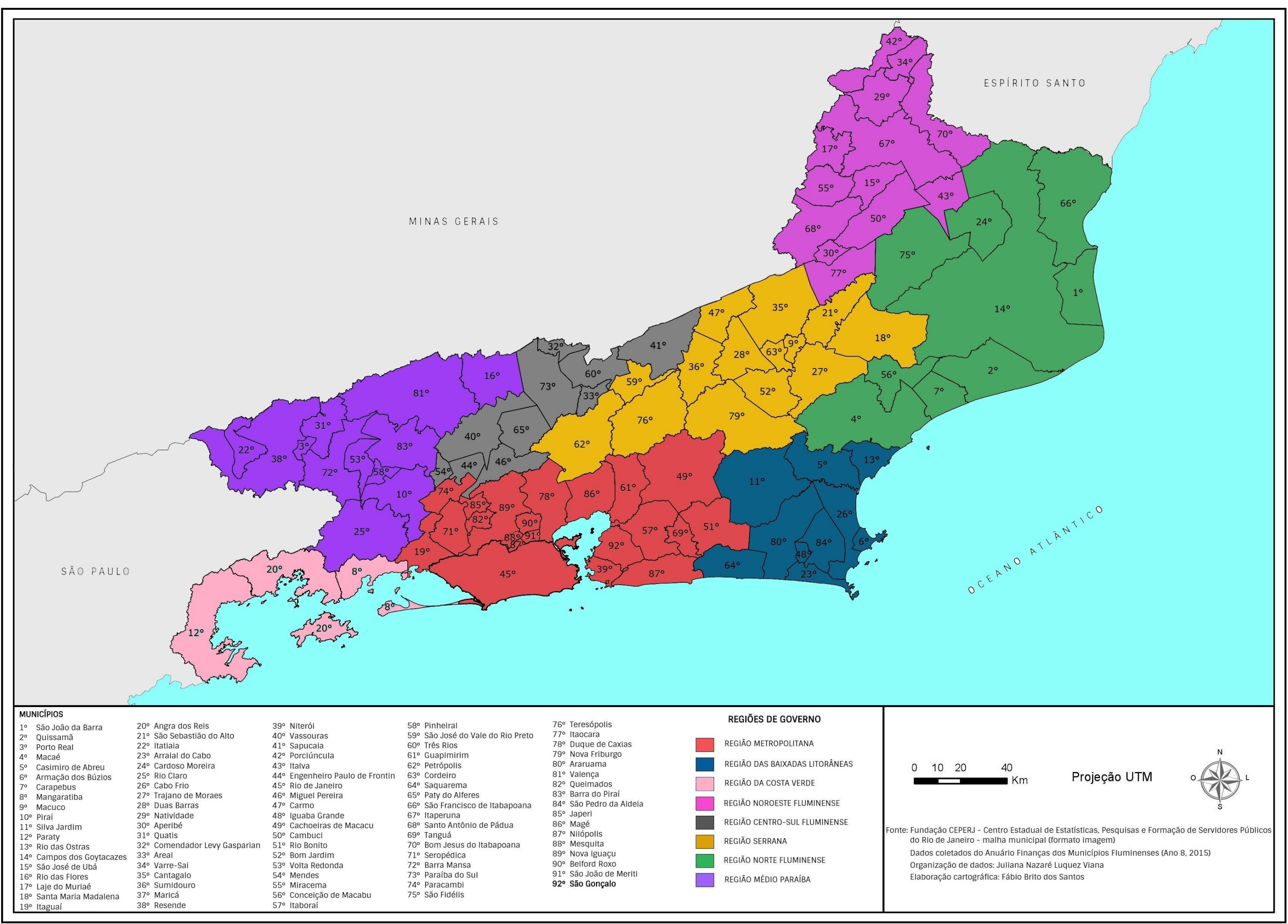


A "arrebentação do padrão urbano" alimenta a luta de classe acirrada no modelo capitalista de produção e apropriação da cidade. Por exemplo, as despesas com o custeio dos serviços prestados pelas prefeituras à população, bem como a operacionalização do funcionamento do ente público e a conservação de seu patrimônio, verificam-se tão menores quanto mais baixas são suas receitas per capita. Os municípios metropolitanos do Rio de Janeiro que aparecem nas piores posições do ranking da receita per capita são também os que se destacam nas piores posições em relação ao custeio per capita de seus citadinos. O município de São Gonçalo, repete o último lugar no ranking dessa variável, seguido de outros 6 municípios metropolitanos (tabela 4).

Tabela 4 - Rio de Janeiro: municípios nas últimas posições do ranking de despesas com custeio per capita (2014)

\begin{tabular}{cccc}
\hline Posição & Municípios & $\begin{array}{c}\text { Despesas com custeio } \\
\text { per capita (em R\$) }\end{array}$ & $\begin{array}{c}\text { População em } \\
2014\end{array}$ \\
\hline $85^{\circ}$ & Japeri & 687,63 & 99.141 \\
$86^{\circ}$ & Queimados & 672,95 & 142.709 \\
$87^{\circ}$ & Nova Iguaçu & 627,53 & 806.177 \\
$88^{\circ}$ & Nilópolis & 609,99 & 158.299 \\
$89^{\circ}$ & Belford Roxo & 545,48 & 479.386 \\
$90^{\circ}$ & São João de Meriti & 431,98 & 460.711 \\
$91^{\circ}$ & Conceição de Macabu & 411,97 & 22.006 \\
$92^{\circ}$ & São Gonçalo & 400,76 & 1.031 .903 \\
\hline
\end{tabular}

Fonte: Anuário Finanças dos Municípios Fluminenses, 2015.

Elaboração: Juliana Luquez.

Conforme apresenta o mapa 3, além de São Gonçalo, 8 municípios metropolitanos assumem, respectivamente, a liderança invertida do ranking de receita per capita e, considerando as 15 últimas posições, 10 são de municípios metropolitanos, dentre os quais 4 são classificados como centralidades (SILVA, 2016; CÂMARA METROPOLITANA, 2017) na 
estrutura policêntrica da conformação metropolitana fluminense: Duque de Caxias, $\left(78^{\circ}\right)$, Nova Iguaçu $\left(89^{\circ}\right)$, São João de Meriti $\left(91^{\circ}\right)$ e São Gonçalo $\left(92^{\circ}\right)$. A centralidade que esses municípios exercem, revela-se, inclusive, na sua pobreza urbana ${ }^{34}$, no seu movimento pendular em busca de emprego formal e qualificação profissional (especialmente formação superior), na procura por moradia, no isolamento cultural e no fomento ao consumo de massa.

As centralidades metropolitanas fluminenses destacam-se entre os maiores fluxos casa/trabalho/estudo do Brasil (tabela 5). Dos 15 maiores fluxos interurbanos e metropolitanos da rede urbana brasileira, 7 ligações se dão na Região Metropolitana do Rio de Janeiro, 4 ligações se dão na Região Metropolitana de São Paulo, 2 na Região Metropolitana de Minas Gerais e outras 2 ligações na Região metropolitana de Pernambuco. A ligação Niterói/São Gonçalo já é a segunda maior do Brasil, ficando atrás de São Paulo/Guarulhos. Essas posições expressam a força da concentração e da centralização das atividades urbanas históricas entre o eixo Rio/São Paulo, mas também a condição da vida urbana posta sob o fio da navalha nas maiores aglomerações metropolitanas do Brasil.

34 A centralidade da pobreza pode ser melhor compreendida no contexto aqui apresentado a partir da Teoria dos Circuitos da Economia Urbana desenvolvida por Milton Santos (2008), para quem "a existência de uma massa de pessoas com salários muito baixos ou vivendo de atividades ocasionais, ao lado de uma maioria com rendas elevadas, cria na sociedade urbana uma divisão entre aqueles que podem ter acesso de maneira permanente aos bens de serviços oferecidos e aqueles que, tendo as mesmas necessidades, não têm condições de satisfazê-las. Isso cria ao mesmo tempo diferenças quantitativas e qualitativas no consumo. Essas diferenças são a causa e o efeito da existência, ou seja, da criação ou da manutenção, nessas cidades, de dois circuitos de produção, distribuição e consumo dos bens e serviços". (SANTOS, 2008, p. 37). Acreditamos que algumas centralidades metropolitanas, por exemplo, Alcântara em São Gonçalo, desenvolvem-se pelas contradições socioespaciais dessa sociedade urbana que se realiza. 
Tabela 5 - Brasil: maiores fluxos de deslocamentos para trabalho e estudo (2015)

\begin{tabular}{c|c|c|c}
\hline \multirow{2}{*}{ UF } & \multicolumn{2}{|c|}{ Ligação } & $\begin{array}{c}\text { Pessoas que } \\
\text { trabalham e } \\
\text { estudam na ligação }\end{array}$ \\
\cline { 2 - 3 } SP & Município A & Município B & 147.757 \\
RJ & São Paulo & Guarulhos & 121.419 \\
MG & Niterói & São Gonçalo & 120.583 \\
PE & Relo Horizonte & Contagem & 119.912 \\
RJ & Rio de Janeiro & Duque de Caxias & 119.599 \\
RJ & Rio de Janeiro & Nova Iguaçu & 110.846 \\
MG & Belo Horizonte & Ribeirão das Neves & 90.629 \\
PE & Recife & Olinda & 90.621 \\
RJ & Rio de Janeiro & São João de Meriti & 85.875 \\
SP & São Paulo & São Bernardo do Campo & 84.196 \\
RJ & Rio de Janeiro & Niterói & 75.835 \\
SP & São Paulo & Santo André & 74.759 \\
RJ & Rio de Janeiro & São Gonçalo & 73.001 \\
SP & São Bernardo do Campo & Santo André & 71.535 \\
RJ & Rio de Janeiro & Belford Roxo & 70.659 \\
\hline
\end{tabular}

Fonte: IBGE, 2015.

Elaboração: Juliana Luquez.

Com o baixo investimento em transporte, a aglomeração urbana fluminense possui uma média de $27,8 \%$ de pessoas que gastam mais de uma hora para se deslocar do seu local de residência até o trabalho em condições de fluência de tráfego (CASA FLUMINENSE, 2017; IBGE, 2010). Essa média sobe para $36,7 \%$ quando considerados apenas os municípios da Baixada Fluminense, São Gonçalo e Itaboraí. O mapa 4 apresenta os maiores fluxos de deslocamentos para trabalho/estudo entre os municípios da RMRJ. Cerca de 194.420 pessoas deslocam-se diariamente entre as cidades de São Gonçalo, Niterói e Rio de Janeiro utilizando-se de transporte individual (carro e moto), ônibus, barcas e vans. Para esse deslocamento não é ofertado o serviço de trem, metrô ou VLT e não existe ciclovia que conecte os municípios limítrofes (São Gonçalo e Niterói). 
Mapa 4 - RMRJ: fluxos de deslocamentos para trabalho e estudo entre municípios (2018)

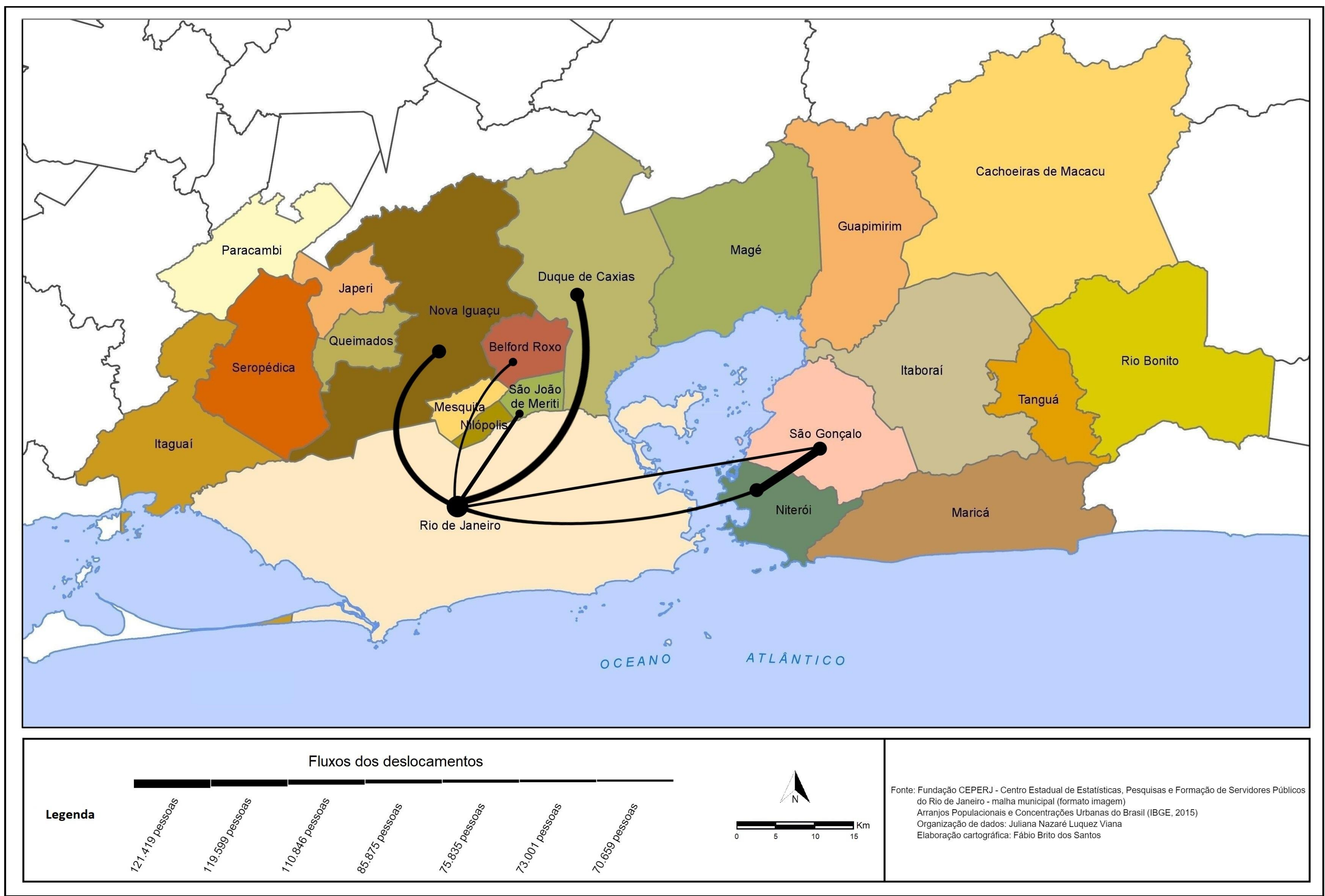


"Mobilidade urbana: uma questão metropolitana". Esse foi o título da matéria do dia 22 de setembro de 2012 do Jornal O Estado de São Paulo, na qual Rodrigues destacou a importância de considerar a mobilidade urbana a partir de todas as complexidades e dimensões da vida urbana e sob o domínio da metropolização, forma mais complexa que a urbanização alcançou. Nas palavras do pesquisador do Observatório das Metrópoles/RJ

Na maioria das vezes, o problema da mobilidade é visto só como um problema de trânsito. Como se para resolver o problema dos congestionamentos não fosse necessário superar outros gargalos do modelo de transporte, e a mobilidade não estivesse relacionada a outros aspectos da vida urbana, como acesso ao emprego, ao estudo e ao lazer. (RODRIGUES, 2012).

A compreensão de Rodrigues sobre a dinâmica metropolitana, a partir do tema mobilidade, nos fornece subsídios analíticos para considerar a escala metropolitana como um paradigma espacial a ser problematizado na criação e execução de políticas públicas de circulação e mobilidade urbanas. Atrelada às questões socioeconômicas que se ampliam na compreensão das dinâmicas de interação e integração das aglomerações urbanas contemporâneas.

Na RMRJ a dinâmica metropolitana se realiza, no âmbito da mobilidade urbana, através do transporte público individual e coletivo (táxi, ônibus, trem, metrô, VLT, BRT, barca, teleférico), transporte particular (carros e motos), transporte alternativo (vans, mototáxi e Uber) e transporte ativo não motorizado (bicicleta e à pé). A existência de um grande leque de opções de transporte na RMRJ não significa, em absoluto, que a distribuição territorial seja proporcional às demandas dos usuários considerando as características socioeconômicas da população mais necessitada e as distâncias entre os locais de moradias e o acesso às oportunidades de emprego, educação e lazer - tampouco que sua qualidade é coerente às tarifas cobradas, ou mesmo que a integração 
entre os modais facilite as baldeações necessárias para a circulação na RMRJ.

Dessa forma, a premissa, da qual partimos para compreender a realidade metropolitana no Rio de Janeiro considerando a problemática da mobilidade urbana, é que a RMRJ possui um sistema metropolitano de transporte socialmente desigual, economicamente caro e ineficiente, territorialmente concentrando na capital a diversidade de modais e, no âmbito das possibilidades alternativas, frágil em termos de infraestrutura e iniciativas públicas de promoção.

A proeminência da RMRJ nos fluxos casa/trabalho/estudo nos leva a perseguir os pressupostos interpretativos de Sobral, o qual contesta a "inflexão econômica positiva fluminense" ao considerar que se trata, em verdade, de uma "estrutura oca", ou seja, "uma estrutura com sérias dificuldades para assegurar um elevado dinamismo em longo prazo e generalizá-lo na totalidade do território" (SOBRAL, 2013, p. 54), mesmo que recentemente reanimada pelo ciclo de grandes investimentos na região metropolitana. Para o autor o "vazio produtivo da Região Metropolitana do Rio de Janeiro" contém fortes indícios de uma desindustrialização relativa no que se refere a uma cadeia complexa e estruturante em estratégias produtivas. Sobre a crise do Rio, Sobral faz uma leitura que vai do econômico ao urbano e sugere que a grave debilidade de sua região metropolitana tem raízes históricas, mas é a partir da década de 1980 que a degradação produtiva regional, devido a fragilidade da indústria de transformação, amplia os efeitos em torno da questão urbana. Para Sobral, "esse padrão de acumulação pode estar corroendo [a] base produtiva" do Estado do Rio de Janeiro, sobretudo o desempenho da região metropolitana. Para o autor

É fundamental se reconhecer o risco de gerar uma crescente "estrutura oca". Isso porque a base industrial fluminense vem perdendo sua histórica diversificação e passou a exibir uma tendência de especialização estrutural no período recente. [...]. Ao invés de apenas uma reestruturação produtiva diante dos novos fatores de dinamização no 
contexto regional e urbano, nota-se uma perda da histórica diversificação do perfil [produtivo]. [...]. Portanto, aparentes sinais de sucesso vêm acompanhados de um rastro de vulnerabilidades potenciais, passíveis de se manifestar ao cessar o surto ou impulso cíclico positivo desencadeado por um conjunto de grandes investimentos (SOBRAL, 2013, p. 65-68).

Entre os anos de 2009 e 2012, a cidade de São Gonçalo esteve no bojo do "impulso cíclico positivo desencadeado por um conjunto de grandes investimentos", impulso esse que reconfigurou a região metropolitano do Rio de Janeiro no que diz respeito as possibilidades de valorização do espaço e de renovação das estratégias do capital para além da dinâmica econômica produtiva. Sobral acredita que a perda de diversificação do perfil produtivo seja o maior prejuízo para a Região Metropolitana do Rio de Janeiro já que, não só a reestruturação produtiva passou a reorganizar os territórios da produção, como também passou a reduzi-los. É justamente nesse ponto que acrescentamos a noção de reestruturação do espaço como importante via interpretativa para as transformações espaciais em São Gonçalo: toda e qualquer dinâmica de reestruturação passa pela problemática do espaço; se por um lado, virtual ou especulativa; por outro lado, unidade característica do real, agrupando formas, funções e estruturas no movimento de realização da produção, da produção do espaço.

As imagens 6, 7 e 8 destacam a importância dos grandes projetos na dinamização da produção do espaço em São Gonçalo e esbarra em um obstáculo interpretativo que considera a crise produtiva do Rio como um elemento inédito no contexto urbano-regional fluminense. $O$ ciclo impulsionado por investimentos que não se realizaram até o presente, já transformou o espaço e a ele incorporou valor substancial. A renovação da acumulação do capital em São Gonçalo pode ter como ponto de partida a compreensão do processo de reestruturação do espaço apreendido em suas rupturas e continuidades. 


\section{Alerj vota acordo com BB que vai} garantir verba para inicio da obra

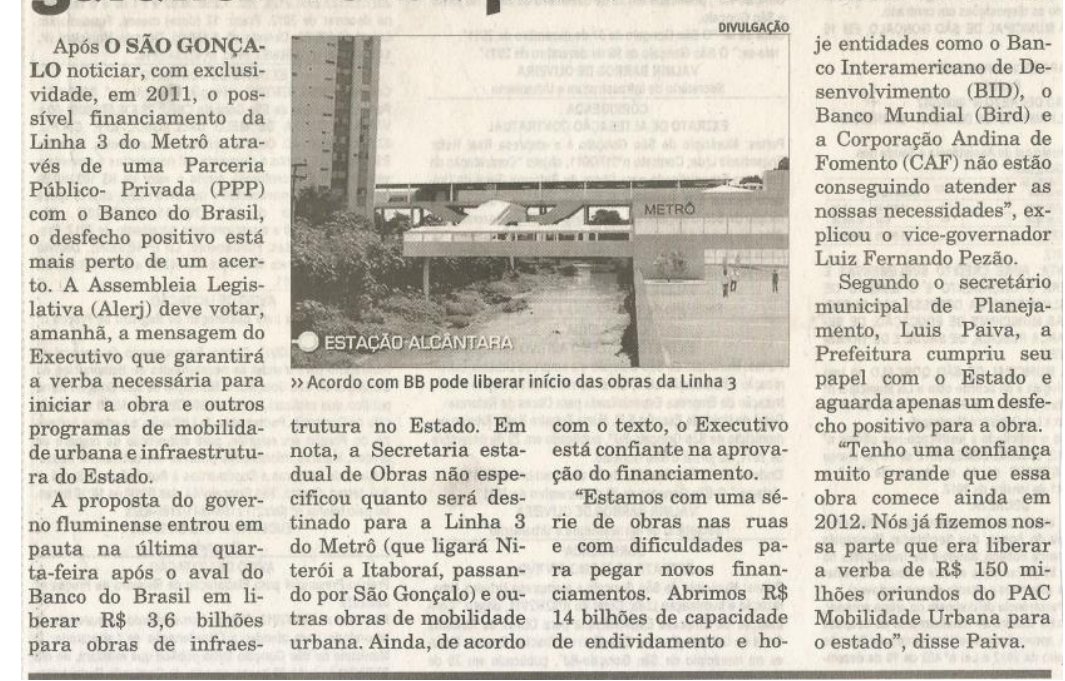

Fonte: Jornal O São Gonçalo, 19/03/2012 - Arquivo pessoal

Imagem 7 - São Gonçalo: governador do Estado do Rio a da linha 3 do Metrô, desconsiderando projeto anterior (2012)

\section{Cabral anuncia nova licitação para Linha 3}

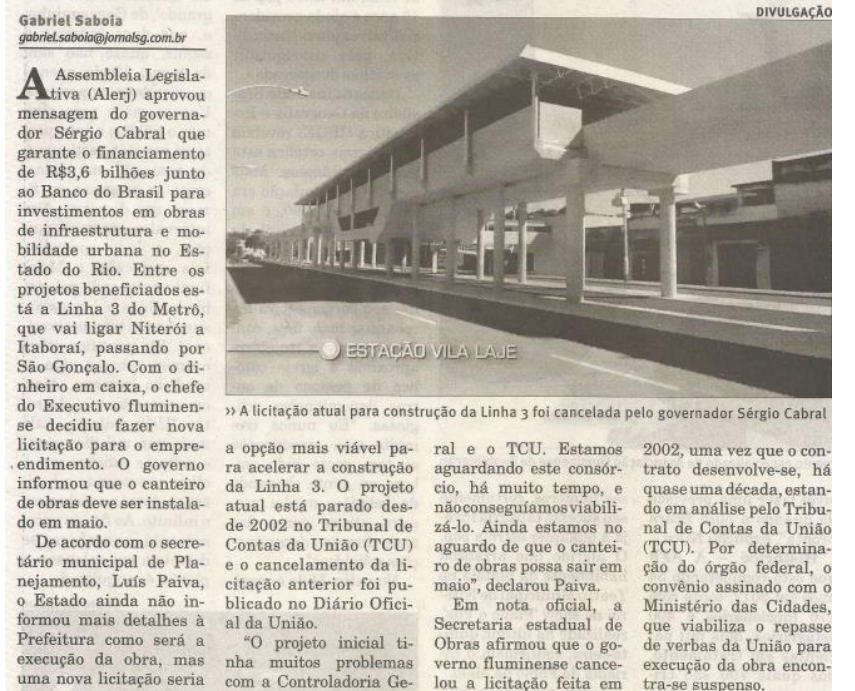

Fonte: Jornal O São Gonçalo, 19/03/2012 - Arquivo pessoa
Imagem 8 - São Gonçalo: anúncio publicitário de empreendimento imobiliário próximo à futura linha 3 do Metrô (2011).
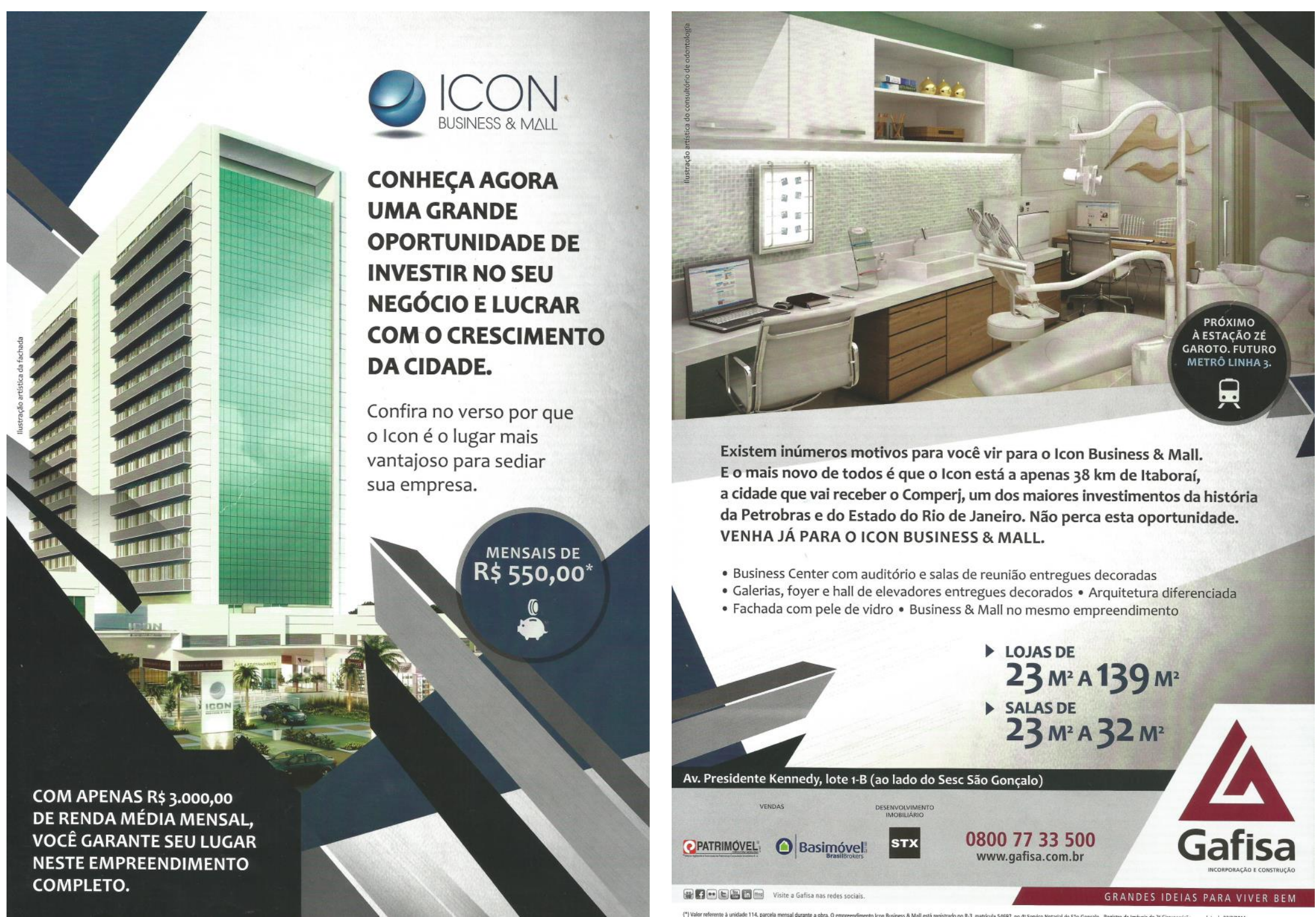

Existem inúmeros motivos para você vir para o Icon Business \& Mall. a cidade que vai receber o o omperi, um dos maiores investimentos da histó da Petrobras e do Estado do Rio de Janeiro. Nâo perca esta oportunidade. VENHA JÁ PARA OICON BUSINESS \& MALL

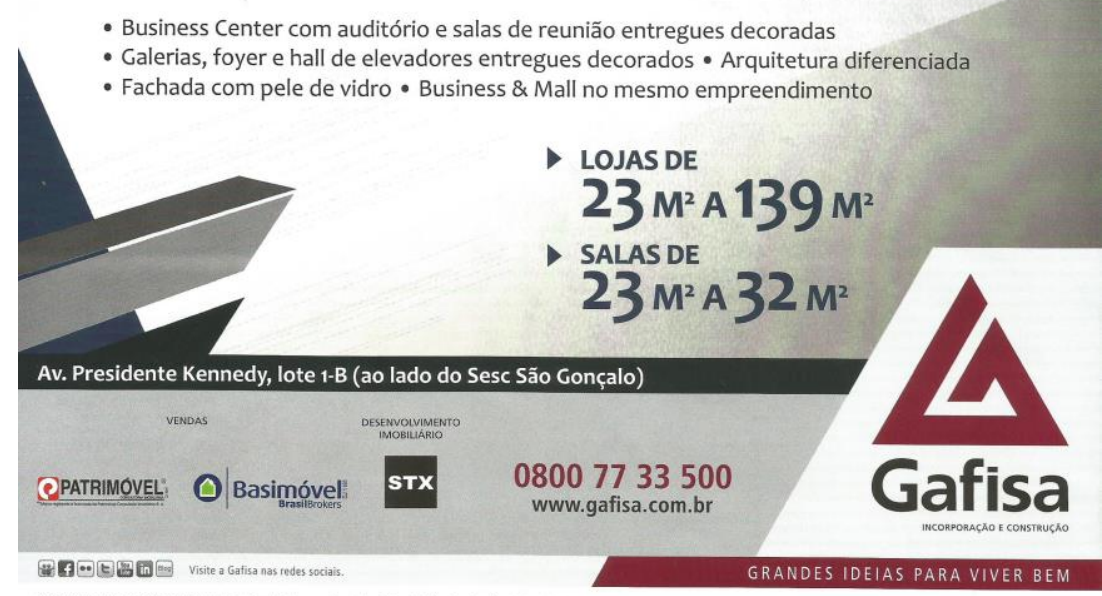

Fonte: Arquivo pessoal - Essa linha nunca teve suas obras iniciadas e está prevista desde os anos 1970 em documentos da antiga FUNDREM 
Considerando ainda a informação trazida nas imagenss 6 e 7, vale destacar que os $R \$ 3,6$ bilhões fornecidos em empréstimos ao Governo do Estado do Rio de Janeiro para viabilizar a execução do Programa de Melhoria da Infraestrutura Rodoviária e Urbana e da Mobilidade das Cidades do Estado do Rio de Janeiro (Pró-Cidades) tinha na pasta 14 (quatorze) projetos divididos em três grupos de interesse, a saber:

Quadro 2 - Projetos que integram o Pró-Cidades (2012)

\begin{tabular}{|c|c|}
\hline \multirow{5}{*}{$\begin{array}{l}\text { Projetos de } \\
\text { Mobilidade }\end{array}$} & Linha 3 do Metrô (Niterói-São Gonçalo) \\
\hline & Linha 4 do Metrô \\
\hline & Arco Metropolitano \\
\hline & $\begin{array}{l}\text { Programa Pró-Estradas - obras de implantação, duplicação e } \\
\text { restauração de rodovias estaduais, como, por exemplo, a Avenida } \\
\text { Presidente Kennedy (RJ-101), no município de Duque de Caxias, a } \\
\text { RJ-148 (Nova Friburgo) e a RJ-234 (São Fidélis-Italva), entre outras }\end{array}$ \\
\hline & Aquisição de barcas para emprego na ligação entre Rio e Niterói \\
\hline \multirow{6}{*}{$\begin{array}{l}\text { Projetos de } \\
\text { Infraestrutura } \\
\quad \text { Urbana }\end{array}$} & $\begin{array}{l}\text { Asfalto na Porta (aplicação de asfalto em vias urbanas não } \\
\text { pavimentadas, compreendendo drenagem, pavimentação, meio fio, } \\
\text { acessibilidade e sinalização em } 91 \text { municípios, além de serviços de } \\
\text { recuperação de vias urbanas naquelas cidades) }\end{array}$ \\
\hline & $\begin{array}{l}\text { Infraestrutura em comunidades (obras de urbanização e } \\
\text { infraestrutura em comunidades de baixa renda na Região } \\
\text { Metropolitana, incluindo pavimentação, drenagem, abastecimento } \\
\text { de água, esgotamento sanitário e iluminação, em locais como } \\
\text { Jacarezinho, Nova Aurora, em Belford Roxo, Queimados, etc.) }\end{array}$ \\
\hline & $\begin{array}{l}\text { Morar Seguro (obras de contenção de encostas e obras de } \\
\text { infraestrutura na Região Serrana) }\end{array}$ \\
\hline & $\begin{array}{l}\text { Somando Forças (obras de infraestrutura urbana e equipamentos } \\
\text { sociais e aquisição de terrenos e equipamentos visando a atender } \\
\text { as demandas dos municípios) }\end{array}$ \\
\hline & $\begin{array}{l}\text { Controle de Cheias nas regiões Norte e Noroeste e recuperação } \\
\text { florestal (obras para minimização de cheias nos rios Muriaé e } \\
\text { Pomba) }\end{array}$ \\
\hline & Elaboração de projetos executivos de infraestrutura \\
\hline \multirow{3}{*}{$\begin{array}{l}\text { Grandes Eventos } \\
\text { (Copa } 2014 \text { e } \\
\text { Olimpíada 2016) }\end{array}$} & $\begin{array}{l}\text { Melhorias de infraestrutura e implantação de equipamentos } \\
\text { turísticos (centros de eventos de Parati e Cabo Frio) }\end{array}$ \\
\hline & $\begin{array}{l}\text { Companhia de Operações Especiais (COE) e Casas de Custódia } \\
\text { (construção de casas de custódias e da sede da COE, no bairro de } \\
\text { Ramos, Zona Norte do Rio) }\end{array}$ \\
\hline & $\begin{array}{l}\text { Recuperação do complexo lagunar da Barra da Tijuca e Jacarepaguá } \\
\text { e Canal da Joatinga. }\end{array}$ \\
\hline
\end{tabular}

Fonte: Governo do Estado do Rio de Janeiro / Secretaria de Obras 
Sabendo que o valor da obra da Linha 4 do Metrô foi alçado em R\$ 5,4 bilhões (mas custou $R \$ 10,4$ ), do Arco Metropolitano em $R \$ 850$ milhões (custando até a data de sua inauguração $R \$ 1,9$ bilhão) e que a implantação da Linha 3 demandaria um montante estimado de $R \$ 1,7$ a $R \$ 3$ bilhões, não é difícil concluir que o empréstimo ao governo estadual não poderia ser considerado viável para a execução dos projetos do PróCidades $^{35}$. Repassadas e esgotadas as possibilidades de financiamento do Governo Federal no que se refere a Linha 3 e com os altos gastos nas obras desenvolvidas como prioridade para a realização dos megaeventos, o Estado do Rio de Janeiro, vem sugerindo desde então a ParceriaPúblico-Privada (PPP) como alternativa à mobilidade metropolitana que inauguraria a extensão do serviço de metrô para fora dos limites da cidade do Rio de Janeiro.

Se a expansão do metrô para municipalidades da região metropolitana do Rio de Janeiro, tendo como expectativa atender uma média de 350 mil pessoas/dia ${ }^{36}$, ampliar a conexão entre centros urbanos e centralidades metropolitanas e redinamizar o setor imobiliário, porque nenhuma empresa considerou a proposta do estado? Em meio a crise econômica anunciada pelo Estado do Rio de Janeiro não seria uma alternativa à reprodução do capital privado? Sim e não. Sim, porque o capital privado sempre busca alternativas à sua reprodução em momentos de desequilíbrios do padrão de acumulação. Não, ele não buscará alternativas se ainda estiver se reproduzindo sem que precise se reinventar, mesmo em meio a uma famigerada crise. Não investir grandes capitais em algumas áreas da região metropolitana do Rio é garantir transferência de valor para outras áreas permitindo a ampliação da extração de mais-valia, produzindo valor a partir de demandas e corroborando para a acumulação via espoliação (HARVEY, 2013) - noção está que será retomada e aprofundada no próximo capítulo.

\footnotetext{
${ }^{35}$ Valores de acordo com o divulgado pelo Governo do Estado do Rio de Janeiro.

36 Média divulgada pelo Governo do Estado do Rio de Janeiro.
} 
Segundo a mensagem publicitária da imagem 8 aquele empreendimento, já construído e inaugurado em São Gonçalo, à época de seu lançamento oferecia vantagens para instalação de empresas voltadas para as atividades de serviços, como escritórios, consultórios, estúdios, etc. Mesmo que o fomento ao desenvolvimento urbano de São Gonçalo viesse anunciado pela instalação do Complexo Petroquímico do Rio de Janeiro na cidade na Itaboraí, o qual contaria com um Centro Integrado de Controle em São Gonçalo, as atividades produtivas estimuladas foram, predominantemente, no setor de comércio e serviço. E toda a infraestrutura comemorada como realização de reivindicações antigas da classe trabalhadora que há décadas cumpre parte de sua longa jornada nos trechos que ligam suas residências periféricas aos seus longínquos postos de trabalho, não passou de faceta da dinâmica especulativa e da predominância das continuidades espoliadoras.

A tabela 6 mostra que dos 115.129 empregos formais em São Gonçalo, 69,8\% estão disponíveis nas atividades econômicas de comércio e serviço. A cidade ocupa o quarto lugar na oferta de emprego formal na Região Metropolitano do Rio de Janeiro, sendo, respectivamente, Duque de Caxias e Niterói, o terceiro e o segundo lugares. A cidade do Rio concentra isoladamente a maior oferta de emprego formal para esses mesmos setores, com 1.628 .804 do total de 2.381.304. A oferta de emprego formal na indústria de transformação encontra destaque no Rio de Janeiro e em Duque de Caxias. Em relação ao setor da construção civil, Rio de janeiro, Niterói e São Gonçalo apresentam o maior número de emprego por atividade. 
Tabela 6 - RMRJ: número de emprego formal por setor de atividade econômica e por município (2016)

\begin{tabular}{|c|c|c|c|c|c|c|c|c|c|}
\hline \multirow[b]{2}{*}{ Município } & \multicolumn{8}{|c|}{ Setor de atividade econômica } & \multirow[b]{2}{*}{ Total } \\
\hline & $\begin{array}{l}\text { Extrativa } \\
\text { mineral }\end{array}$ & $\begin{array}{l}\text { Indústria de } \\
\text { transformação }\end{array}$ & $\begin{array}{c}\text { Serviços } \\
\text { industriais de } \\
\text { utilidade } \\
\text { pública }\end{array}$ & $\begin{array}{c}\text { Construção } \\
\text { civil }\end{array}$ & Comércio & Serviços & $\begin{array}{c}\text { Administração } \\
\text { pública }\end{array}$ & $\begin{array}{c}\text { Agropecuária, } \\
\text { extração } \\
\text { vegetal, caça e } \\
\text { pesca }\end{array}$ & \\
\hline Rio de Janeiro & 8.524 & 159.626 & 37.663 & 103.449 & 409.492 & 1.219 .312 & 440.088 & 3.150 & 2.381 .304 \\
\hline Niterói & 1.720 & 8.481 & 4.432 & 8.640 & 34.936 & 103.862 & 13.847 & 929 & 179.847 \\
\hline Duque de Caxias & 135 & 30.645 & 1316 & 3.890 & 43.442 & 61.684 & 15.649 & 57 & 156.818 \\
\hline São Gonçalo & 150 & 11.505 & 898 & 5.087 & 34.523 & 45.873 & 16.953 & 140 & 115.129 \\
\hline Nova Iguaçu & 126 & 10.116 & 978 & 3.040 & 33.233 & 37.008 & 15.961 & 82 & 100.544 \\
\hline São João de Meriti & - & 4 & 511 & 469 & 17.089 & 30.599 & 4.246 & 8 & 56.937 \\
\hline Belford Roxo & 3 & 2.102 & 89 & 885 & 9.304 & 9.765 & 10.752 & 3 & 32.903 \\
\hline Itaguaí & 209 & 3.771 & 75 & 2.853 & 5.313 & 7.860 & 8.429 & 93 & 28.603 \\
\hline Itaboraí & 59 & 3.818 & 79 & 2.397 & 7.608 & 8.514 & 5.327 & 179 & 27.981 \\
\hline Magé & 201 & 1.921 & 167 & 1.496 & 6.763 & 5.364 & 8.594 & 83 & 24.589 \\
\hline Nilópolis & - & 795 & 4 & 278 & 5.044 & 8.343 & 3.629 & 4 & 18.097 \\
\hline Rio Bonito & 30 & 1.769 & 14 & 2.204 & 3.149 & 6.702 & 5.579 & 344 & 16.791 \\
\hline Mesquita & - & 929 & 3 & 442 & 3.588 & 8.902 & 2.565 & 17 & 16.446 \\
\hline Queimados & 71 & 2.722 & 88 & 250 & 4.928 & 4.733 & 2.457 & 2 & 15.251 \\
\hline Maricá & 81 & 1.136 & 7 & 614 & 4.877 & 5.327 & 2.890 & 79 & 15.011 \\
\hline Seropédica & 489 & 1.482 & 356 & 239 & 2.351 & 5.367 & 2.789 & 49 & 13.098 \\
\hline Cachoeiras de Macacu & 49 & 1.003 & 269 & 89 & 1.553 & 1.133 & 2.552 & 732 & 7.380 \\
\hline Japeri & 49 & 1.157 & 2 & 94 & 1.425 & 901 & 1.900 & 5 & 5.533 \\
\hline Paracambi & 8 & 1.203 & 2 & 103 & 1.467 & 1.009 & 1.493 & 26 & 5.311 \\
\hline Guapimirim & 16 & 609 & 43 & 67 & 1.555 & 1.313 & 1.395 & 121 & 5.119 \\
\hline Tanguá & 23 & 461 & 4 & 367 & 833 & 630 & 1.333 & 63 & 3.709 \\
\hline
\end{tabular}

Fonte: Relação Anual de Informações Sociais do Ministério do Trabalho e Emprego - RAIS / MTE, 2016.

Elaboração: Juliana Luquez. 
O cenário apresentado na tabela 6 nos reaproxima da perspectiva de Sobral (2013) que considera a inflexão econômica positiva do Estado do Rio de Janeiro, anunciada desde meados da década de 1990, como uma falácia. Isso porque os únicos setores que apresentaram uma taxa de crescimento médio anual, entre 1995 e 2010, como Veículos Automotores $(17,5 \%)$, Indústria Extrativa (8\%), Bebidas $(4,2)$ e o Refino de Petróleo e Álcool (1,9\%), ${ }^{37}$ não deram conta nem de dinamizar as atividades produtivas na Região Metropolitana do Rio de Janeiro, tampouco de absorver a mão de obra dispersa territorialmente na região, mas concentrando força de trabalho na Metrópole Rio.

Se concordamos com Maricato (2015) que a urbanização no momento da estruturação urbano-industrial se realizou pelos baixos salários pagos à classe trabalhadora, acrescentamos que, no atual momento de estruturação metropolitano-financeira, a fase mais complexa dessa urbanização realiza-se entre rupturas e continuidades: renovações estratégicas na dinâmica de produção do espaço e reprodução do capital e renda mínima à classe trabalhadora terciária.

Não nos parece ser conveniente considerar a crise do Rio como uma incógnita na problemática urbano-metropolitana do Rio de Janeiro. Essa está sendo gestada desde o momento urbano-industrial e tem servido, paradoxalmente, para resguardar a acumulação do capital privado para desfrutar de uma reprodução ampliada no momento da estruturação metropolitano-financeira, entre as estabilidades provisórias e as reestruturações estratégicas. A reestruturação do espaço não mudou a lógica de concentração e centralização das atividades urbanas e econômicas na Metrópole Rio, mas permitiu a ampliação das condições gerais de produção (LENCIONI, 2007) e acumulação para o seu em torno, reforçada na fragmentação do tecido urbano e apoiada na produção da riqueza extraída de atividades terciárias, sob baixos salários e frágil vínculo empregatício.

\footnotetext{
${ }^{37}$ Pesquisa Industrial Mensal Produção Física / IBGE.
} 
O mapa 5 revela que a dinâmica regional apreendida nos percursos intra e interurbanos realizados diariamente entre São Gonçalo e as demais municipalidades da Região Metropolitana do Rio de Janeiro estão fortemente ligados à atual reestruturação do espaço. Tal dinâmica não se realizou pelos investimentos infraestruturais ou políticas públicas de incentivo à produção e ao emprego, mas sim pela reconfiguração do espaço em uma escala metropolitana visando ampliar o consumo individual em detrimento do consumo coletivo. São Gonçalo, mesmo com uma população pobre, baixa arrecadação per capita, nenhum investimento em mobilidade urbana, insere-se no mapa das centralidades metropolitanas fluminenses (SILVA, 2016) pois é a quarta cidade que mais oferta emprego formal nos setores de serviço e comércio e dessa forma também atrai para seu território as demandas urbanas reproduzidas nas franjas do leste metropolitano. Dizendo de outra forma, São Gonçalo reproduz na relação com sua área de influência a mesma dinâmica que se processa na sua relação com as cidades do Rio de Janeiro e Niterói.

A reprodução da metrópole nas suas centralidades periféricas insere-se na discussão sobre o processo de reestruturação do espaço na atual fase da urbanização fluminense e a dinâmica de produção do espaço sob um movimento que se realiza entre descontinuidades e continuidades perversas. 
Mapa 5 - São Gonçalo: fluxos intra e interurbanos (2018)

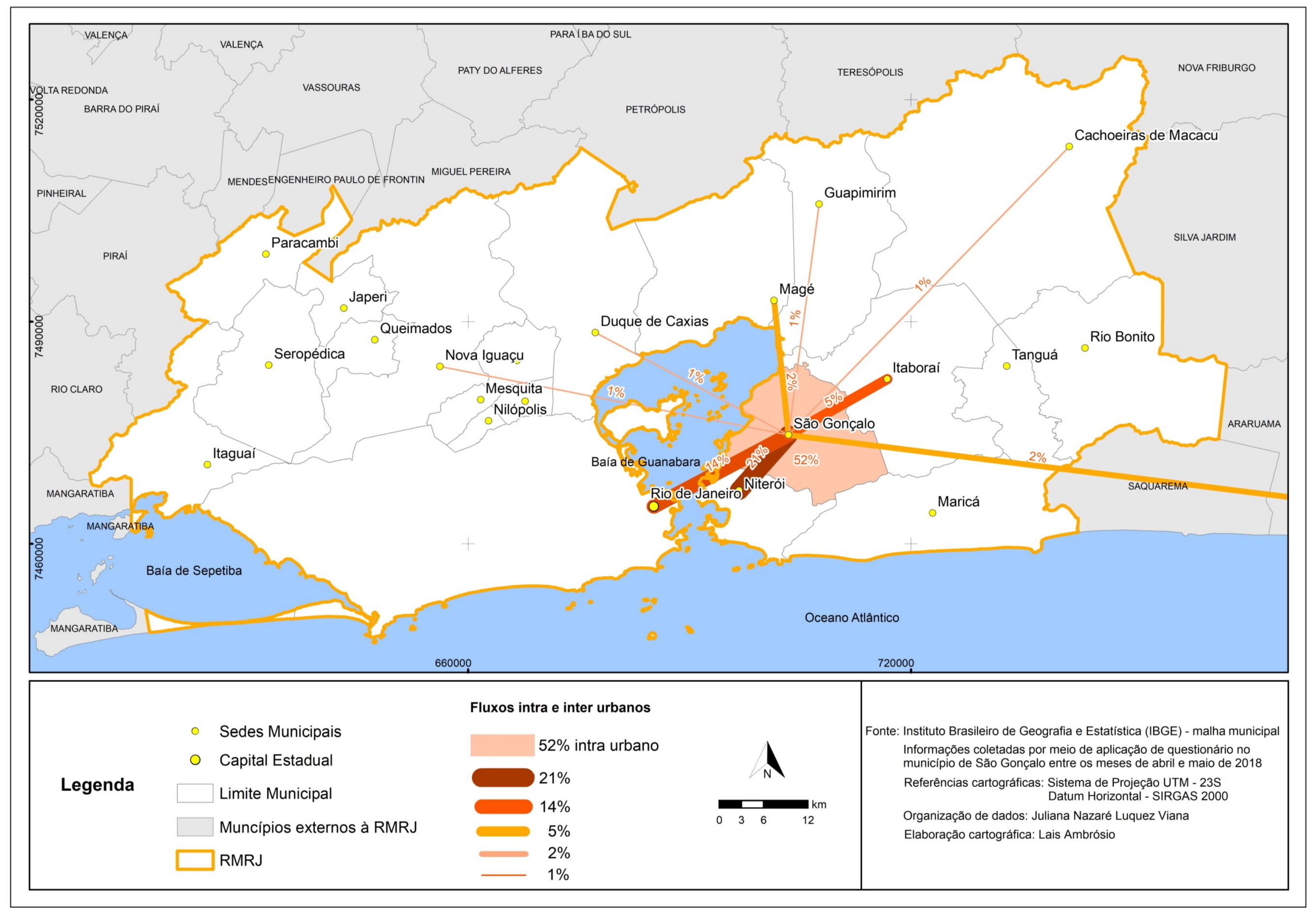


Não é, então, irrisório que a população entrevistada aponte emprego/oportunidade como o terceiro problema que mais afeta a vida na cidade (gráfico 4). Por exemplo, no que se refere à oportunidade de estudo e qualificação profissional, São Gonçalo possui 6 (seis) Instituições de Ensino Superior, sendo apenas duas públicas e somente uma de ensino presencial, 1 (um) Instituto Federal e 2 (duas) Unidades da Fundação de Apoio à Escola Técnica do Estado do Rio de Janeiro (FAETEC); Itaboraí possui 8 (oito) Instituições de Ensino Superior, todas privadas, 1 (um) Instituto Federal e 1 (uma) Unidade da FAETEC ${ }^{38}$. Para um morador do bairro Areal, em Itaboraí, que deseja cursar uma graduação presencial na Universidade do Estado do Rio de Janeiro Campus São Gonçalo (UERJ/FFP) e utilizar-se do transporte público intermunicipal, ele percorrerá $30 \mathrm{~km}$ e precisará tomar 3 (três) diferentes linhas de ônibus, cada trecho com o custo médio de $\mathrm{R} \$ 4,00$.

Gráfico 4 - São Gonçalo: problemas que afetam a vida na cidade (2018)

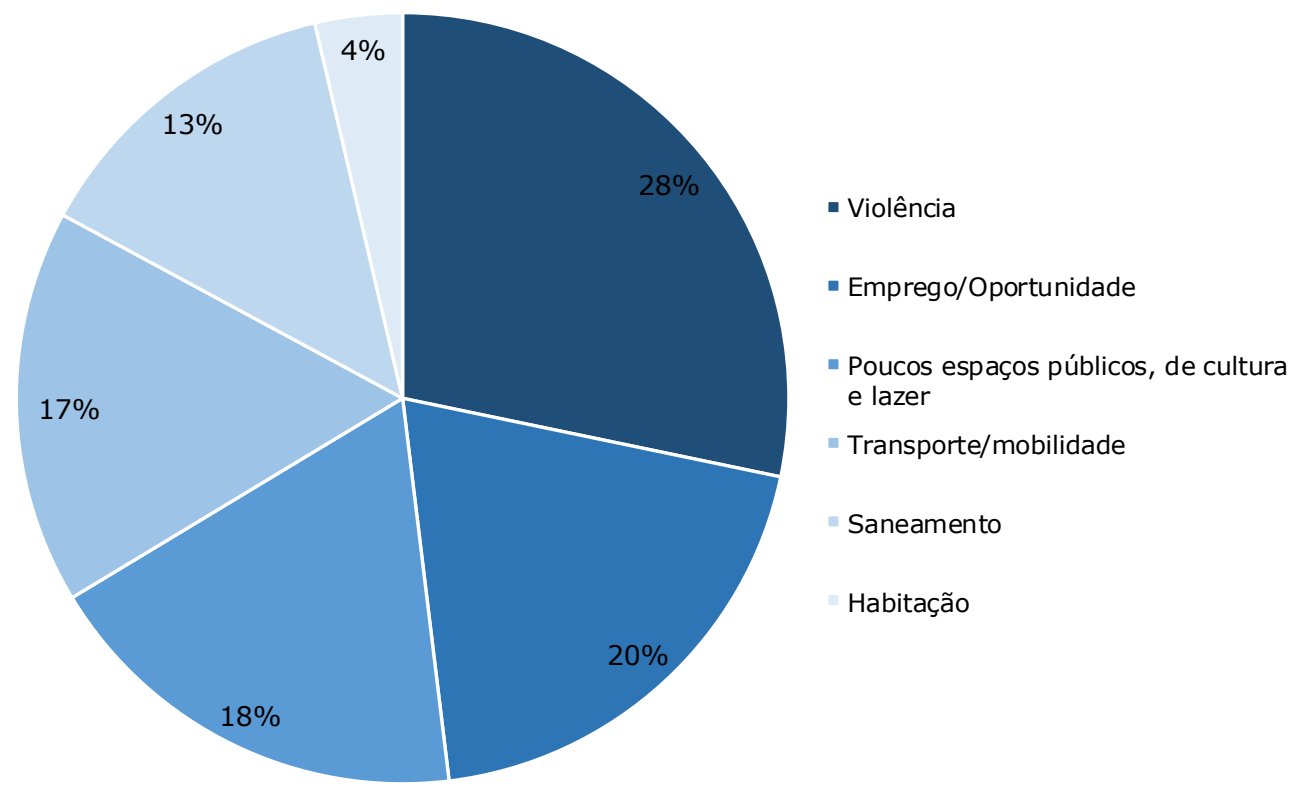

Fonte: Dados obtidos por meio de amostragem (2018)

Elaboração: Juliana Luquez.

\footnotetext{
38 Ministério da Educação / Instituto Nacional de Estudos e Pesquisas Educacionais Anísio Teixeira, 2010.
} 
Em alguns casos as prefeituras municipais disponibilizam ônibus fretados para conduzir os estudantes universitários às Instituições de Ensino Superior de São Gonçalo e Niterói. Mas se o estudante encontra um lugar no mercado para vender sua força de trabalho com o objetivo de financiar seus custos com a formação fora de sua cidade de residência, uma nova dinâmica de circulação se imporá. Nesse contexto, inferimos que a mobilidade caótica na Região Metropolitana do Rio de Janeiro representa grandes lucros à iniciativa privada que responde, predominantemente, pelo sistema de transporte urbano e metropolitano fluminense ${ }^{39}$.

O gráfico 4 também expõe a vulnerabilidade da população urbana, em que $28 \%$ aponta a violência como o atual problema de maior constrangimento à vida na cidade. A respeito disso, São Gonçalo é o segundo município da Região Metropolitana do Rio que mais registrou tiroteios em 2017 e 2018, respectivamente, 126 e 242 registros ${ }^{40}$. A situação alcançou seu ponto máximo no dia 16 de fevereiro de 2018, quando o Governo Federal decretou a intervenção de suas forças na segurança pública do Rio de Janeiro (DECRETO No 9.288). Para a sua execução, a intervenção contou com a liberação de uma verba de $R \$ 1,2$ bilhão do Governo Federal (imagens 9, 10 e 11). [O mesmo governo que, em 2016, propôs através da PEC 241 o congelamento de investimentos nas áreas de saúde e educação por duas décadas. Em São Gonçalo, aos $20 \%$ dos respondentes que consideram a falta de emprego/oportunidade como o segundo maior problema que afeta a vida na cidade, somam $18 \%$

\footnotetext{
${ }^{39}$ A auto viação Mauá, maior empresa de transporte público de São Gonçalo, figurou o sexto lugar no ranking das maiores empresas de transporte do Brasil. A auto viação Flores, que atua na região da Baixada Fluminense, liderou o ranking em primeiro lugar. Das 25 maiores empresas do setor no Brasil, 11 atuam no Estado do Rio de Janeiro, sendo 10 na RMRJ. O levantamento considerou a atuação de empresas de ônibus para o transporte metropolitano. (OTM EDITORA MAIORES E MELHORES DO TRANSPORTE, 2013, p. 127-128).

40 Os dados são de um levantamento realizado periodicamente por um aplicativo de celular chamado Fogo Cruzado. Este aplicativo tem funcionado como um instrumento de mediação entre a população de diversos pontos da Região Metropolitana do Rio e a realidade metropolitana denunciada pela própria sociedade conectada através das mídias virtuais.
} 
que lamentam a ausência de espaços públicos, de cultura e lazer. A crise do Rio parece se distanciar cada vez mais dos cifrões e se aproximar da problemática urbana, reinaugurada sob o domínio do fato metropolitano e de sua necessária reestruturação das representações do espaço - do espaço concebido, aquele "dos planificadores, tecnocratas retalhadores e agenciadores $^{41 "}$ (LEFEBVRE, 2000, p. 48) à quem interessa o primado especulativo do concebido sobre o vivido].

Imagem 9 - São Gonçalo: operação da intervenção militar em duas comunidades. Participaram da ação 4.300 militares das Forças Armadas, 120 policiais militares e 80 policiais civis. Trechos da Avenida Brasil (Rio de Janeiro), Ponte Rio-Niterói e Rodovia Niterói-Manilha (São Gonçalo) precisaram ser fechados para o deslocamento das tropas

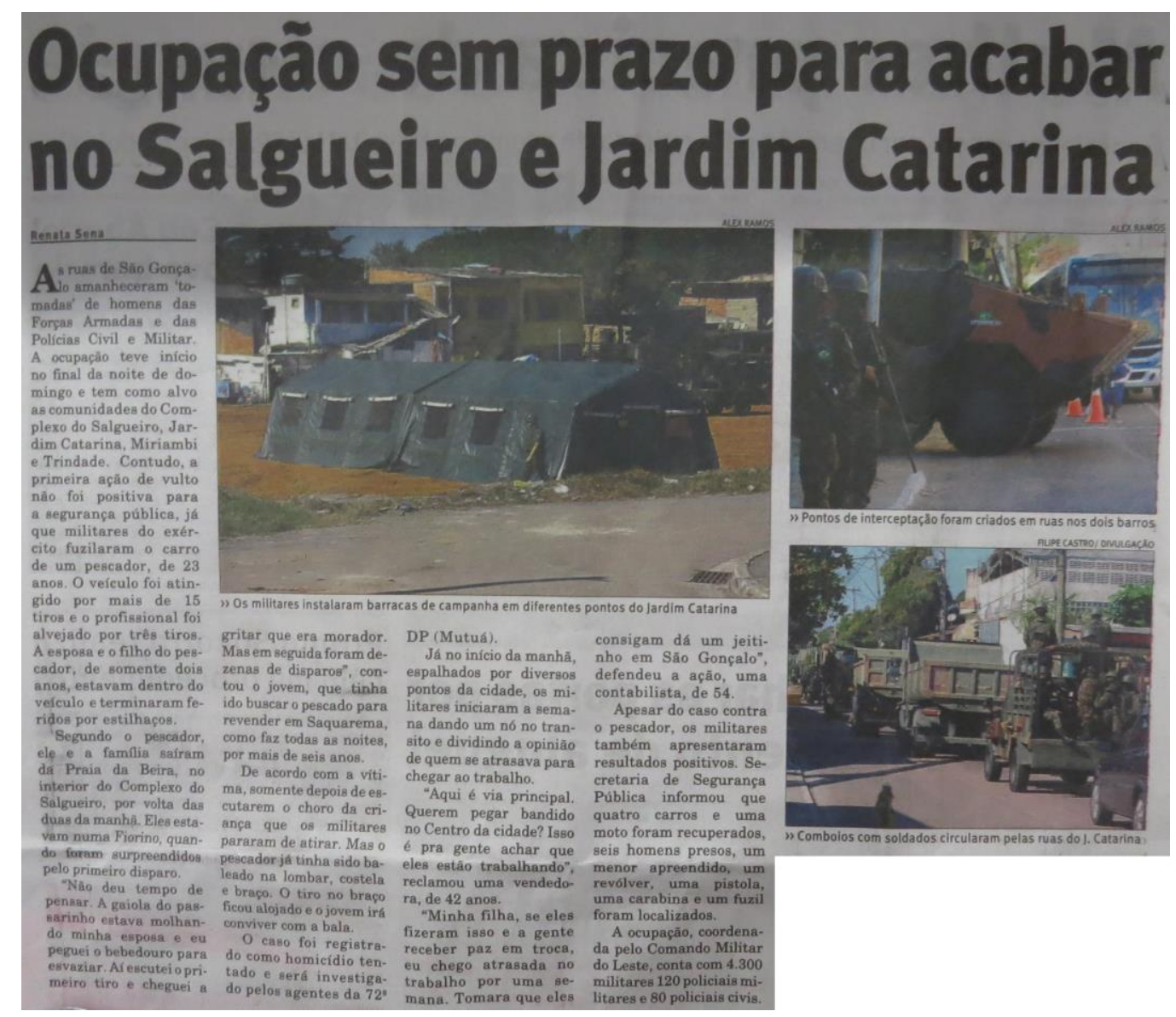

Fonte: Jornal O São Gonçalo, 17/07/2018 - Arquivo pessoal

41 Texto original: «des planificateurs, des technocrates découpeurs et agenceurs » (LEFEBVRE, 2000, p. 48). 
Imagens 10 e 11 - Operação policial com o apoio de tropas civis e militares no Complexo do Fazenda dos Mineiros, São Gonçalo: inibição ao tráfico de drogas e constrangimento à circulação dos moradores (set./2018).
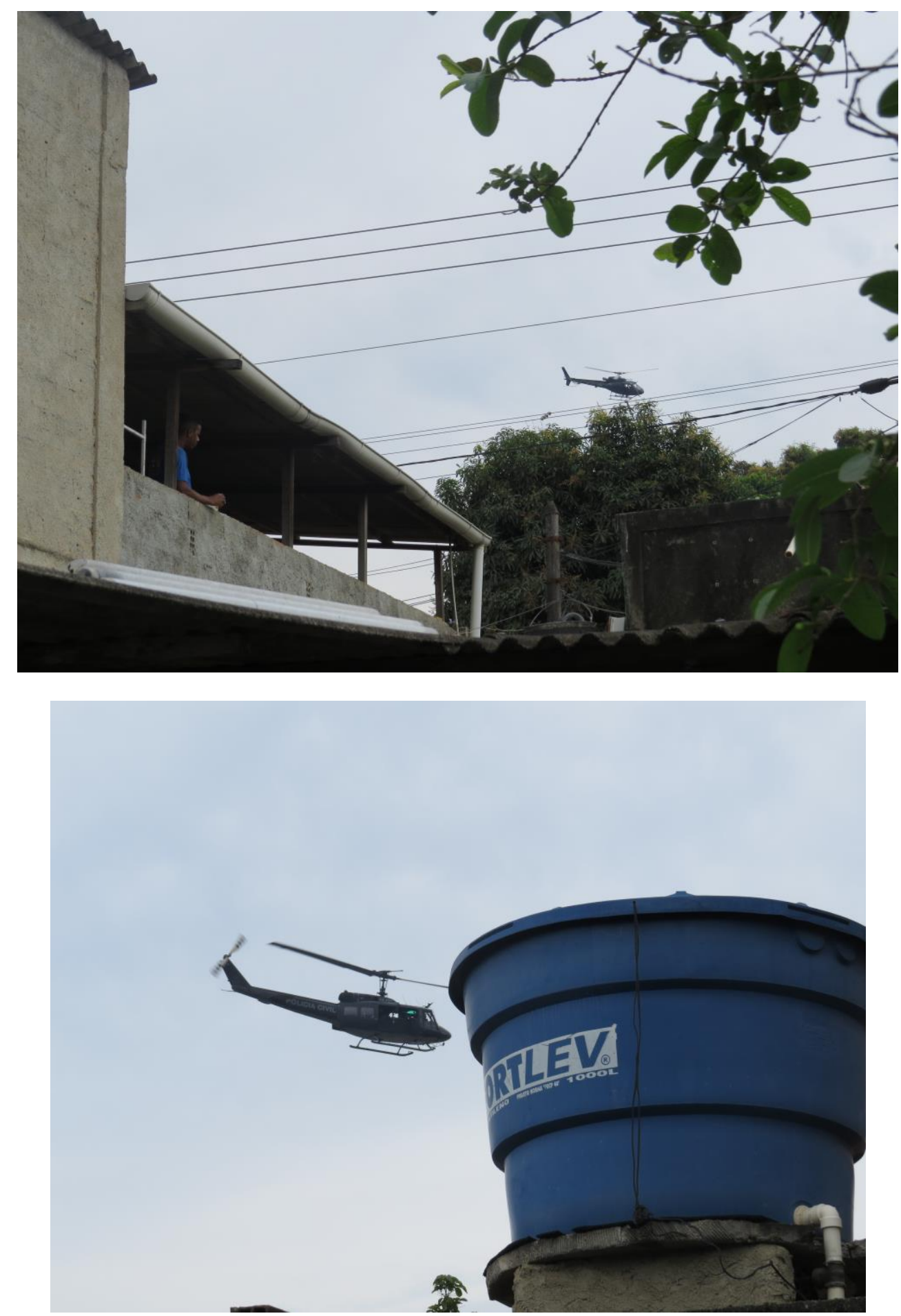

Crédito: Juliana Luquez.

A vulnerabilidade à qual está sujeita a população urbana de São Gonçalo não encontra raízes no atual momento de crise do Rio, inclusive a 
própria crise não se explica em sua atualidade - como ainda insistiremos. Analisemos os números a seguir (tabela 7):

Tabela 7 - São Gonçalo: tiroteios/disparos de arma de fogo (2018)

\begin{tabular}{c|c|c|c|c|c|c|c}
\hline \multicolumn{3}{c|}{5 meses antes do início da intervenção federal } & \multicolumn{3}{|c}{5 meses depois do início da intervenção federal } \\
\hline $\begin{array}{c}\text { Tiroteios/ } \\
\text { Disparos }\end{array}$ & $\begin{array}{c}\text { Presença } \\
\text { agente de } \\
\text { segurança }\end{array}$ & Mortos & Feridos & $\begin{array}{c}\text { Tiroteios/ } \\
\text { Disparos }\end{array}$ & $\begin{array}{c}\text { Presença } \\
\text { agente de } \\
\text { segurança }\end{array}$ & Mortos & Feridos \\
\hline 331 & 47 & 139 & 85 & 432 & 95 & 108 & 79 \\
\hline
\end{tabular}

Fonte: Laboratório Fogo Cruzado, jun./jul. 2018

Elaboração: Juliana Luquez.

A intervenção, executada pelo Governo Federal, em cinco meses de ações não conseguiu reduzir ou anular os números de mortos e feridos na cidade de São Gonçalo, ampliou o efetivo de seus agentes envolvidos com os tiroteios e disparos de arma de fogo que subiram de 331 para 432, entre fevereiro e julho de 2018. Na problemática urbana das cidades brasileiras e, especialmente, no contexto da aglomeração metropolitana do Rio de Janeiro, há de se considerar que para além dos tradicionais agentes produtores do espaço urbano (proprietários dos meios de produção, proprietários fundiários, promotores imobiliários, Estado, grupos sociais), personagens já conhecidos consolidam seus domínios territoriais na cidade por meio de sua capacidade de intervir na produção do espaço e reconfigurar áreas estratégicas para a geração de uma riqueza que depende das continuidades perversas da urbanização: as facções criminosas e as milícias que atuam na disputa pelo mercado de drogas e na provisão de serviços urbanos e suas demandas (como gás, televisão e internet, moto-táxi e veículos de passeios que realizam o transporte intra-urbano, segurança de estabelecimentos comercias locais, roubos de carga para alimentar um comércio informal). ${ }^{42}$

Desse contexto insurgem as necessidades e exigências mais proeminentes (gráfico 5). Encontramos em São Gonçalo, a partir de

\footnotetext{
${ }^{42}$ A respeito desse tema no Rio de Janeiro, Souza $(2005 ; 2008)$ possui uma contribuição
} notória e relevante. 
Maricato (2015), a chave interpretativa que sugere uma ruptura no processo de urbanização, entre a questão habitação que funda a problemática urbana no Brasil industrial e a mobilidade urbano-regional que funda a problemática metropolitana. A reestruturação do espaço, inclusive, vai criar nexos com esses dois momentos da dinâmica de produção da cidade e do modo de vida urbano - conforme veremos no capítulo 2. A cidade que é produzida nesse segundo momento é, em nosso entendimento, aquela que Pereira (2011) vai chamar de cidade emergente.

A cidade emergente é, cada vez mais, um lugar privilegiado de produção de espaços exclusivos em que a apropriação do valor subordina e concorre para a materialização da riqueza social. Mesmo que essa subordinação do espaço se torne cada vez mais imaterial e produzida fora do âmbito territorial, no seu entorno regional, nacional ou mundial, na ordem distante. Todavia essa acumulação continua a se materializar na ordem próxima, onde te repercussões nos artefatos arquitetônicos e nos emergentes padrões urbanísticos que exacerbam a forma de produção imobiliária (mercantil) e alteram a cultura urbanística ao não privilegiar o atendimento das condições materiais da reprodução da força de trabalho, mas o atendimento da infraestrutura e logística para a reprodução do capital. (PEREIRA, 2011, p. 25). 
Gráfico 5 - São Gonçalo: urgências para a cidade (2018)

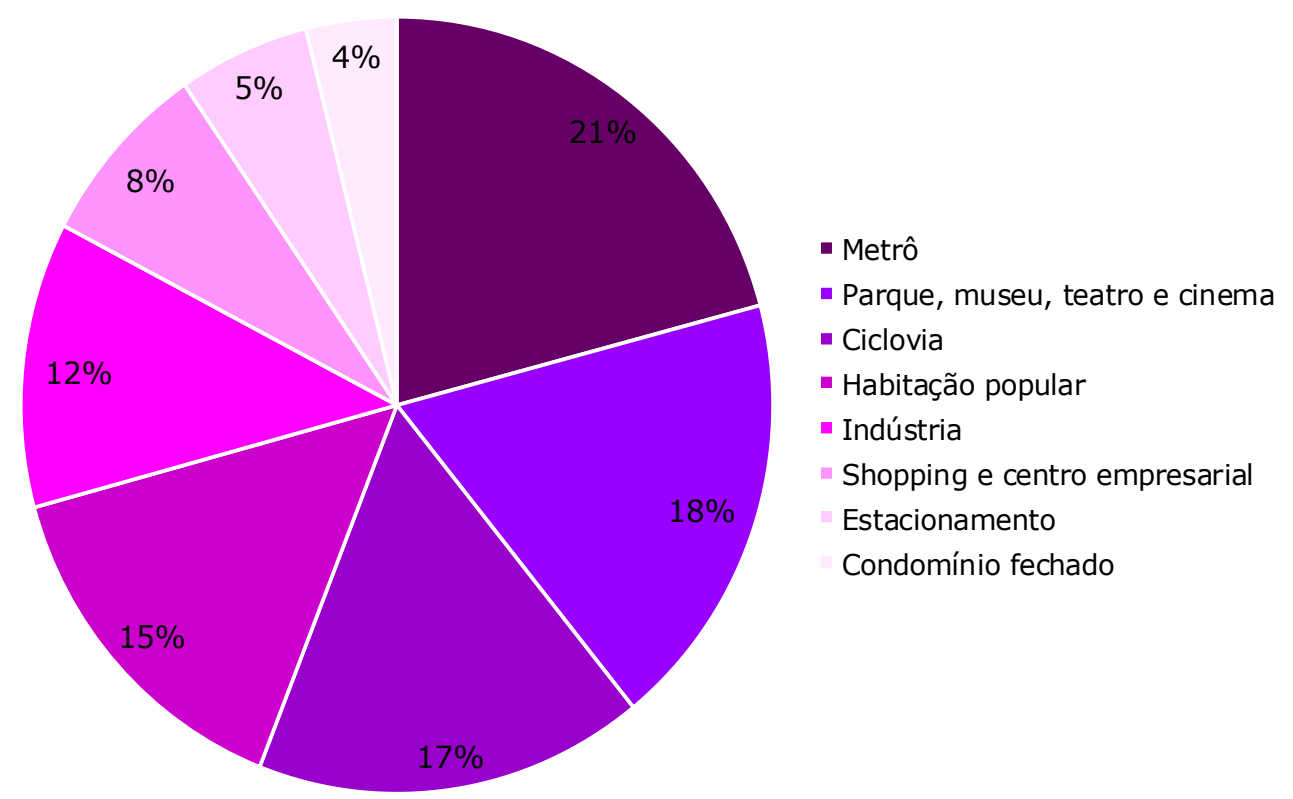

Fonte: Dados obtidos por meio de amostragem (2018)

Elaboração: Juliana Luquez.

As urgências se apresentam, em verdade, como diferentes formas de apropriação capazes de ativar novas dinâmicas dos processos de produção e reestruturação do espaço, no modo, no tempo e no ritmo da realização da sociedade urbana. Dentre os respondentes, a implantação de uma linha de metrô aparece como a maior urgência para a cidade de São Gonçalo, seguida por instalação de parque, museu, teatro e cinema; ciclovia; habitação popular e indústria. As menores urgências são condomínios fechados; estacionamento; shopping e centro empresarial. Porém, diante do que expomos até aqui, vemos que a apropriação do espaço urbano tem obedecido a lógica de produção de uma cidade emergente, característica do novo momento de reprodução do capital, do espaço e da sociedade. O metrô aparece como urgência da massa trabalhadora que se desloca diária e frequentemente entre as cidades de São Gonçalo, Niterói e Rio de Janeiro, mas também aparece como forma de apropriação do valor na dinâmica fundiária nos eixos da reestruturação, como vimos no exemplo do empreendimento Icon Bussiness \& Mall e nos demais empreendimentos lançados nas imediações das futuras estações do projeto Linha 3 do Metrô, apresentado pelo 
Governo do Estado do Rio de Janeiro desde 2002, revisto em 2012 e intrêmulo até então.

As pessoas se reproduzem na cidade subjugadas nas continuidades perversas e, por vezes, encobertas no modus operandi da estrutura de relações sociais de produção; já o capital se reproduz na mesma lógica e também produzindo rupturas. A reestruturação do espaço permite a compreensão desse movimento complexo, simultâneo e complementar, capaz de homogeneizar, fragmentar e hierarquizar o espaço através da reprodução das relações sociais de produção, essa sendo aquele "processo complexo que arrasta consigo contradições e não só as repete, as reduplica, mas também as desloca, as modifica, as amplifica (LEFEBVRE, 1973, p. 6). O gráfico 6 expressa tal complexidade dos processos combinados na análise proposta.

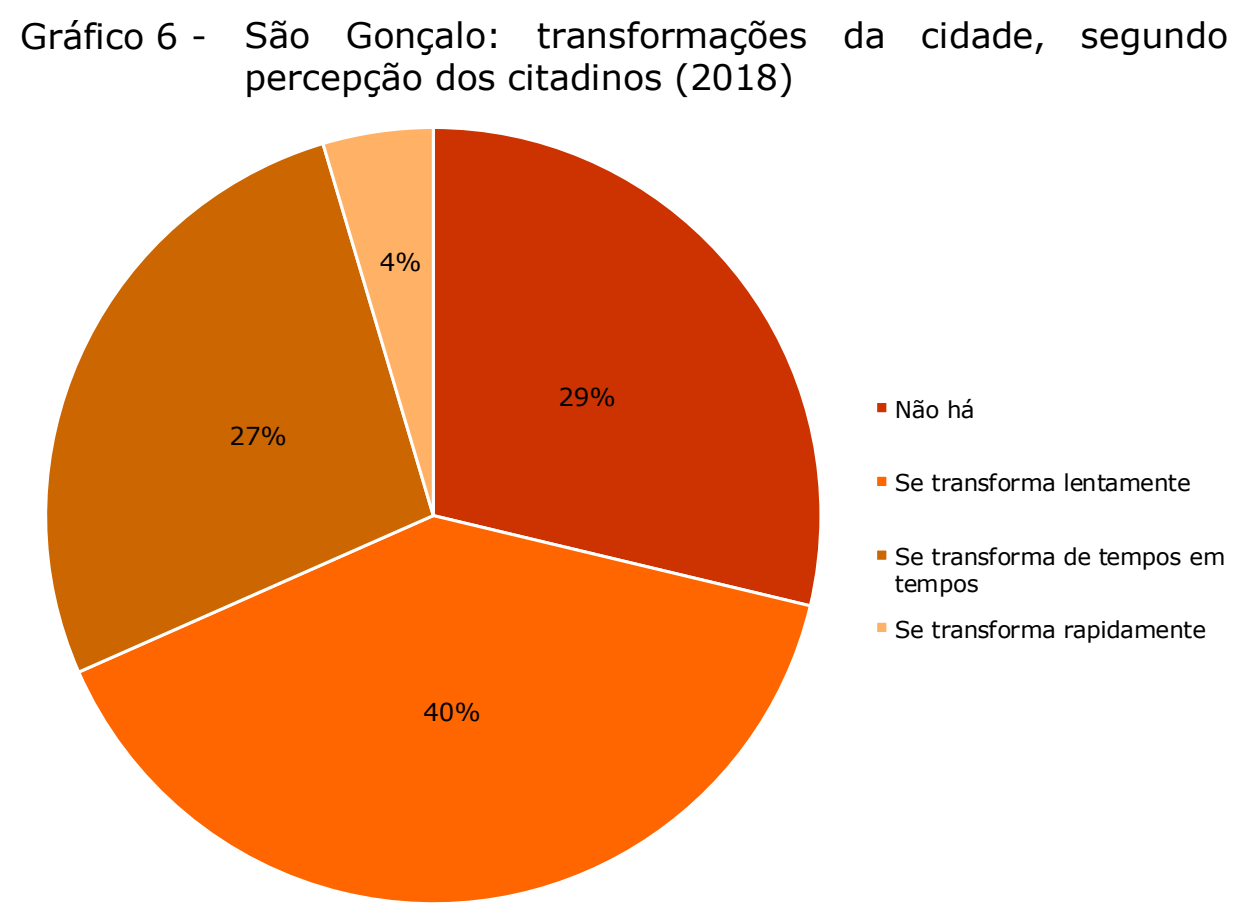

Fonte: Dados obtidos por meio de amostragem (2018)

Elaboração: Juliana Luquez.

É praticamente unânime entre os pesquisadores dos estudos urbanos e das cidades que o ritmo das transformações espaciais na consolidação da urbanização alcançou uma dinâmica tão intensa que 
dividi-os entre os proclamadores do fim da cidade e os que criam tratar-se de sua metamorfose. Temos como premissa que a realidade urbana é apreendida muito mais pelas formas do urbano do que pela cidade em si, isso porque, "o urbano é um continente que se descobre e que se explora à medida que é construído" (LEFEBVRE, 2016, p. 77). A classe trabalhadora que constrói a cidade pelas vias contraditórias das relações sociais de produção, pouco reconhece seu trabalho na realização da produção total, que inclui a produção do espaço (CARLOS, 2011). Nisso, $40 \%$ dos respondentes consideram não haver transformação alguma na cidade de São Gonçalo, 29\% percebem as transformações em um ritmo lento, $27 \%$ identificam que tais transformações ocorrem periodicamente e apenas $4 \%$ afirmam que as transformações na cidade vêm se dando com intensidade.

A hipótese que apresentamos à esta análise é a de que se trata de uma reprodução da vida por continuidades (periferização, espoliação e segregação), do capital por rupturas necessárias à manutenção das continuidades e do espaço pela simultaneidade desses dois processos, acarretando no movimento de estruturação-desestruturaçãoreestruturação compreendido, na atualidade, pelas formas complexas, estruturas renováveis e funções flexíveis.

Se no nível global apreende-se mais a dinâmica das transformações espaciais, no nível da cidade (o nível das mediações) a percepção dessas transformações está subordinada a apropriação do espaço. Isso não significa que os residentes, trabalhadores e transeuntes de São Gonçalo não sintam os efeitos da circulação da informação, da renovação das técnicas, da compressão tempo-espaço, processos esses intrínsecos ao de metropolização. Isso significa que a cidade foi negada pela estruturação urbano-industrial, estilhaçada pela fragmentação metropolitana, mas transformada em abstração urbana e chave para a compreensão do concreto, a sociedade urbana.

O caminho que trilhamos até aqui, visando extrair a problemática 
urbana da crise urbana do Rio de Janeiro, nos coloca diante de uma questão: estaríamos falando de uma crise urbana ou de um momento no qual se sobrepõem fases críticas da urbanização fluminense? Primeiramente, é preciso esclarecer o que vemos de diferente entre a primeira e a segunda questão. Se afirmamos uma crise urbana no Rio, pensamos correr o risco de repousar nossa análise apenas na reunião de fatos, sem os dissolver no movimento de realização da sociedade em meio a sua dinâmica de produção do espaço. Se admitirmos uma sobreposição de fases críticas, caminhamos em uma perspectiva que dissolve formas, funções e estruturas no movimento dinâmico da produção do espaço e alcança a problemática urbana.

Para $98 \%$ dos respondentes, São Gonçalo é a expressão da crise urbana (gráfico 7). Vivemos uma crise urbana? Se sim, porque não a reconhecemos na dinâmica de transformação da cidade? Apontar a crise requer a percepção de contendas entre diferentes interesses. Se não, porque a descrevemos como parte quase naturalizada da urbanização?

Gráfico 7 - São Gonçalo: vivemos uma crise urbana? (2018)

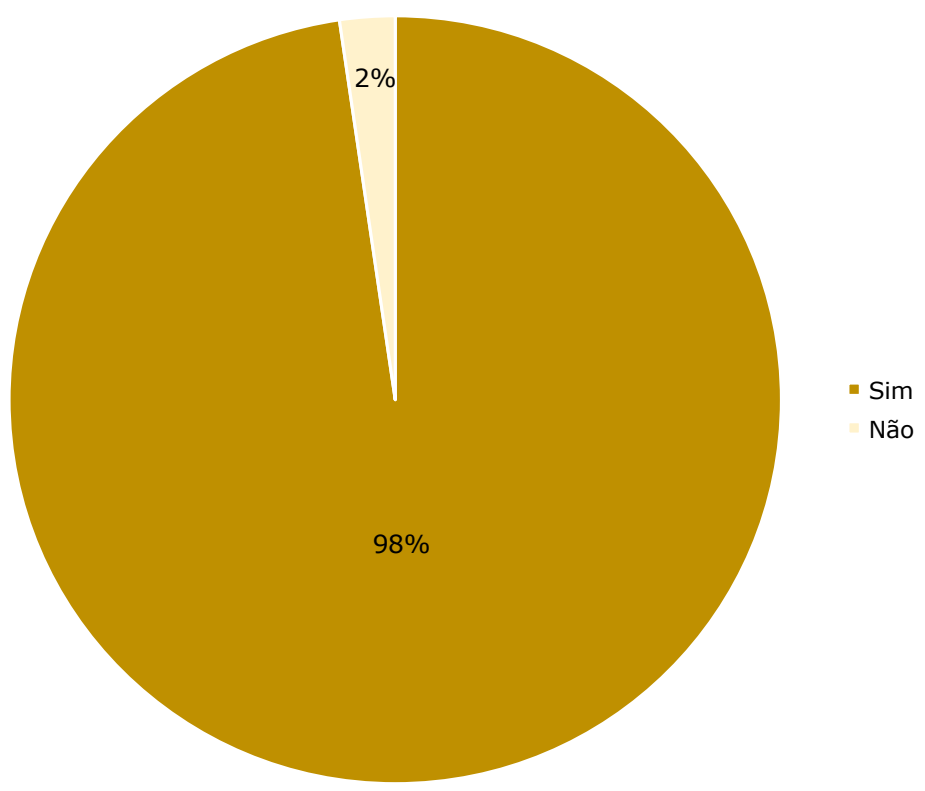

Fonte: Dados obtidos por meio de amostragem (2018)

Elaboração: Juliana Luquez.

Em verdade, a crise urbana é um campo cego, pois é nela que 
desaparecem as continuidades e as rupturas se tornam mediação entre a reestruturação, reprodução e apropriação. A hipótese que apresentamos é que a dinâmica da produção do espaço urbano em São Gonçalo, inserida na consolidação do espaço metropolitano fluminense, pode ser compreendida a partir do processo de reestruturação, considerado em três fases críticas: 1) a urbanização que precede a industrialização e é capturada por ela; 2) a urbanização espoliadora; e 3) a urbanização especulativa (ou financeira) que impõe à problemática urbana análises e interpretações para além do dualismo centro-periferia no contexto da atual conformação da metrópole e de sua região.

Para Lefebvre

Pode-se dizer que a sociedade industrial acarreta a urbanização. Essa constatação e essa fórmula tornaram-se banalidades. Todavia, é menos banal perguntar-se se as consequências do processo, ou seja, a urbanização, não se tornaram rapidamente mais importantes que sua causa inicial: a industrialização. A tese aqui apresentada é a de que a problemática urbana desloca e modifica profundamente a problemática originada do processo de industrialização. Enquanto a maioria dos teóricos e também dos "práticos" que procedem de maneira empírica consideram ainda a urbanização como uma consequência exterior e menor, quase acidental, do processo essencial, a industrialização, nós afirmamos o inverso. Nesse processo de duplo aspecto ocorre algo muito importante; em termos clássicos: um salto qualitativo. 0 crescimento quantitativo da produção econômica produziu um fenômeno qualitativo que se traduz, ele próprio, por uma problemática nova: a problemática urbana. (LEFEBVRE, 2016, p. 76).

A problemática urbana, quando extraída da realidade do Rio de Janeiro, revela rupturas e continuidades que contribuem para uma periodização analítica que só ganhará sentido se retomada em sua totalidade (totalidade aqui entendida como totalidade urbana). Rupturas permitem-nos apreender os momentos do movimento, continuidades concretizam sua realização. Reestruturações revelam os álibis da produção do espaço - o processo de reestruturação é tomado de agora em diante como o ponto de partida para aprofundarmos essa compreensão. 
Se a cidade explodiu, bem como suas contradições, em formas espaciais cada vez mais dispersas, apropriar-se dela é investir em possibilidades mais criativas e posturas mais contestáveis ao processo de reestruturação do espaço. A contribuição desse trabalho repousa na tentativa de fornecer à sociedade argumentos críticos à essas posturas contestáveis, caminho esse já reconhecido como possiblidade, mas ainda não conhecido como prática política (gráfico 8 ).

Gráfico 8 - São Gonçalo: caminhos para buscar soluções à Crise Urbana (2018)

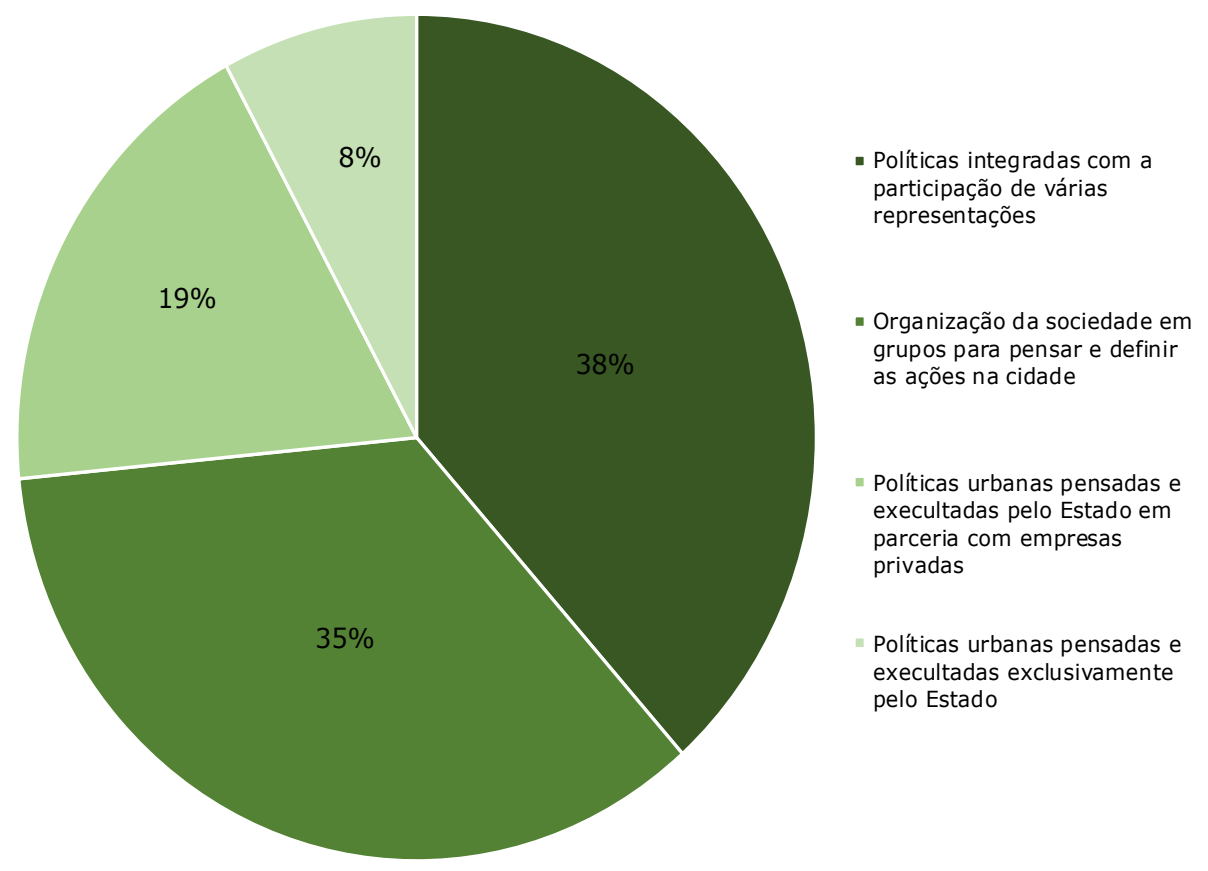

Fonte: Dados obtidos por meio de amostragem (2018)

Elaboração: Juliana Luquez.

Nos próximos capítulos, ampliaremos nossos argumentos dissolvendo-os na análise das fases de reestruturação do espaço em São Gonçalo como recurso metodológico à compreensão da produção do espaço da aglomeração metropolitana fluminense. 


\section{CAPÍTULO 2}

\section{PRODUÇÃO DO ESPAÇO METROPOLITANO FLUMINENSE: DINÂMICA E PROCESSOS NA ANÁLISE ESPACIAL}




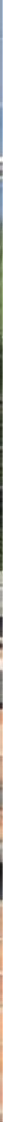

1.

Imagem 12 - Vista da ponte Rio-Niterói às margens da BR-101 ene sà encalo, (2018 Chedito: Juliana Lugue Ma 


\subsection{Referências analíticas para a discussão da produção do espaço e dos processos que a fundamentam}

Neste capítulo buscamos discutir a simultaneidade e a dinâmica entre os processos de produção e reestruturação do espaço afim de identificar as fases críticas do movimento que os realizam. Estas fases eclodem via rupturas e imprimem novos ritmos à urbanização ao mesmo tempo que carregam continuidades, por vezes, encobertas perante novas possibilidades de realização da sociedade, do seu espaço e de seus tempos. Tomaremos, em nossa análise, as seguintes questões: a) quais processos espaciais estão engendrados na dinâmica de produção do espaço fluminense? b) quais rupturas redefiniram, até agora, o permanente movimento de sua conformação? c) é possível compreender esse movimento a partir das fases do processo de reestruturação, considerando as transformações ocorridas em São Gonçalo?

Para tanto recorreremos à algumas referências analíticas para a discussão da produção do espaço e dos processos que a fundamentam, considerando a análise proposta nesta seção, a saber: produçãoreprodução, urbanização, metropolização, fragmentação e reestruturação. Essa discussão será construída, inicialmente, a partir de premissas e perspectivas interpretativas de autores que consideramos ímpares em suas contribuições para a construção dos argumentos que são aqui apresentados. Um aspecto teórico se faz importante à essa discussão. Ele refere-se à noção de produção do espaço.

Tese central [...]. O modo de produção organiza - produz ao mesmo tempo que certas relações sociais, seu espaço (e seu tempo). É assim que ele se realiza. Seja dito, en passant: o socialismo engendrou um espaço? Se não, é que o modo de produção socialista ainda não tem existência concreta. O modo de produção projeta essas relações no terreno, o qual reage sobre elas. Sem que haja correspondência exata, definida de antemão, entre as relações sociais e as relações espaciais (ou espaçotemporais). Não se pode afirmar que o modo de produção capitalista tenha, desde o início, "ordenado", por inspiração 
ou inteligência, sua extensão espacial, destinada a se estender em nosso tempo ao planeta inteiro! De início, houve utilização do espaço existente, por exemplo, das vias aquáticas (canais, rios, mares), depois das estradas; na sequência, construção de estradas de ferro, para continuar pelas autoestradas e pelos aeroportos. Nenhum meio de transporte no espaço desapareceu inteiramente, nem a caminhada, nem o cavalo, nem a bicicleta, etc. Contudo, um espaço novo se constituiu no século $X X$, à escala mundial; sua produção, não terminada, continua. O novo modo de produção (a sociedade nova) se apropria, ou seja, organiza para seus fins, o espaço preexistente, modelado anteriormente. Modificações lentas penetram uma espacialidade já consolidada, mas às vezes a subvertem com brutalidade (caso dos campos e paisagens rurais no século XIX). (LEFEBVRE, 2000, p. XXVI) ${ }^{43}$

\section{A partir da noção de produção do espaço, Lefebvre dá} contribuições significativas para pensarmos além de um inventário das transformações socioespaciais e da percepção das coisas sobre o espaço, ultrapassando a descrição de seus elementos. O espaço é uma abstração concreta e são as relações sociais que nele contém que fundamentam o seu caráter social. No dizer do autor, o espaço social é "produto-produtor, ou seja, gerado pelo modo de produção, mas intervém em todos os níveis [... $]^{\prime 44}$ (LEFEBVRE, 1986, p. 160). A noção de produção do espaço considera

\footnotetext{
43 Texto original: Thèse centrale [...]. Le mode de production organize - produit - em même temps que certains rapports sociaux -, son espace (et son temps). C'est ainsi qu'il s'accomplit. Soit dit en passant, le « socialisme » a-t-il engendré un espace ? Si non, $c^{\prime}$ est que le mode de production socialiste n'a pas encore d'existence concrète. Le mode de production projette sur le terrain ces rapports, ce qui réagit sur eux. Sans qu'il y ait correspondance exacte, assigné d'avance, entre les relations sociales et les relations spatiales (ou spatio-temporalles). On ne peut dire que le mode de production capitaliste ait dès le debut « ordenné », par inspirations ou intelligence, son extension spatiale, qui devait s'ètendre en notre temps à la planète entière ! Il y eut d'abord utilisation de l'espace existant, par exemple des voies d'eau (canaux, fleuves, mers) puis des routes ; ensuite constructions des chemin de fer, pour continuer par les autoroutes et les aérodromes. Aucun moyen de transport dans l'espace $\mathrm{na}$ entièrement disparu, ni la marche à pied, ni le cheval, ni le vélo, etc. Pourtant c'est un espace nouveau qui s'est constitué, au XX siècle, à l'èchelle mondialle ; sa production, non terminée, continue. Le nouveau mode de production (la société nouvelle) s'approprie, c'est-à-dire aménage à ses fins, l'espace pré-exitant, modelé antérieurement. Modifications lentes, pénétrant une spacialité déjà consolidée, mais la bouleversant parfois avec brutalité (cas des campagnes et paysages ruraux au XXe siècle). (LEFEBVRE, 2000, p. XXVI).

44 Texto original: [...] l'espace social em tant que produit-producteur, c'est-à-dire engendré par le mode de production, mais intervenant à tous les niveaux [...]. (LEFEBVRE, 1986, p. 160).
} 
as transformações produzidas pelo capitalismo (enquanto modo de produção dominante) como momentos da histórica realização da sociedade, fazendo-nos atentar para um importante processo: produçãoreprodução.

O espaço social contém [...] as relações sociais de reprodução, a saber, as relações biofisiológicas entre os sexos, as idades, com a organização específica da família - e as relações de produção, a saber, a divisão do trabalho e sua organização, portanto, as funções sociais hierarquizadas. Esses dois encadeamentos, produção e reprodução, não podem se separar: a divisão do trabalho repercute na família e aí se sustenta; inversamente, a organização familiar interfere na divisão do trabalho; todavia, o espaço social discerne essas atividades para "localizá-las". Não sem fracassos! Mais precisamente, até o capitalismo, imbricamse tais níveis, o da reprodução biológica e o da produção socioeconômica, envolvendo assim a reprodução social, a da sociedade que se perpetua na sequência de gerações, apesar dos conflitos, confrontações, lutas e guerras. Será necessário mostrar que o espaço desempenha um papel decisivo nessa continuidade. Com o capitalismo, e sobretudo com o neocapitalismo "moderno", a situação se complica. Três níveis se imbricam, o da reprodução biológica (a família) - o da reprodução da força de trabalho (a classe operária como tal) - o da reprodução das relações sociais de produção, ou seja, das relações constitutivas da sociedade capitalista, cada vez mais (e progredindo) desejadas e impostas como tais. O papel do espaço nesse triplo arranjo deve ser estudado especificamente. (LEFEBVRE, 2000, p. $41)^{45}$

\footnotetext{
45 Texto original: L'espace contient [...] les rapports sociaux de reproduction, à savoir les rapports bio-physiologiques entre les sexes, les âges, avec l'organisation spécifiée de la famille - et les rapports de production, à savoir la division du travail et son organisation, donc les fonctions sociales hiérarchisées. Ces deux enchaînements, production et reproduction, ne peuvent se séparer : la divison du travail se répercute dans la famille et s'y entretient; inversement l'organisation familiale intrfère avec la division du travail ; pourtant, l'espace social discerne, pour les «localiser » ces activités. Non sans èchecs ! Plus précisément, jusqu'au capitalisme, s'imbriquent ces niveaux, celui de la reproduction biologique et celui de la production socio-économique, enveloppant ainsi la reproduction sociale, celle de la société qui se perpétue dans la suite des générations, malgré les conflits, affrontements, luttes et guerres. Que espace, dans cette continuité, joue un rôle décisif, il faudre le monter. Avec le capitalisme et surtout le néo-capitalisme « moderne » la situation se complique. Trois niveaux s'imbriquent, celui de la reproduction biologique (la famille) - celui de la reproduction de force de travail (la classe ouvrière comme telle) - celui de la reproduction des rapports sociaux de production, c'est-à-dire des rapports constitutifs de la société capitaliste, de plus en plus (et de mieux em mieux) voulus et imposés comme tels. Le rôle de l'espace dans ce triple agencement doit s'studier spécifiquement. (LEFEBVRE, 2000, p. 41).
} 
Para Lefebvre o conceito de produção se inscreve com duas acepções: uma econômica e outra filosófica (LEFEBVRE, 1986). Em relação a acepção econômica, o conceito de produção se limita à coisas e objetos, requer uma precisão ilusória, uma abstração formal que não abarca o sentido de produção de formas e obras múltiplas (jurídicas, religiosas, ideológicas, artísticas, políticas). A acepção filosófica do conceito de produção é considerada por Lefebvre como aquela que possui um sentido mais amplo, na qual "os homens enquanto seres sociais produzem sua vida, sua história, sua consciência, seu mundo"46 (LEFEBVRE, 2000, p. 83) ou, ainda no dizer do autor, "o homem é sua própria criação"47 (LEFEBVRE, 1986, p. 98). Acrescenta-se ao conceito de produção, a partir da contribuição da teoria do espaço social de Lefebvre, uma terceira acepção: a espacial. Essa terceira acepção não só retoma as anteriores, como as supera e permite uma compreensão completa (e complexa) do conceito de produção e do processo de produçãoreprodução da sociedade, de seu espaço, de suas relações.

A prática espacial, que engloba produção e reprodução, lugares especificados e conjuntos espaciais próprios a cada formação social, que assegura a continuidade numa relativa coesão. Essa coesão implica, no que concerne ao espaço social e à relação de cada membro de determinada sociedade ao seu espaço, ao mesmo tempo uma competência certa e uma certa performance. As representações do espaço, ligadas às relações de produção, à "ordem" que elas impõem e, desse modo, ligadas aos conhecimentos, aos signos, aos códigos, às relações "frontais". Os espaços de representação, apresentam (com ou sem código) simbolismos complexos, ligados ao lado clandestino e subterrâneo da vida social, mas também à arte, que eventualmente poder-se-ia definir não como código do espaço, mas como código dos espaços de representação ${ }^{48}$. (LEFEBVRE, 2000, p. 42 - grifos do autor).

\footnotetext{
46 Texto original : «les hommes em tant qu'êtres sociaux produisent leur vie, leur histoire, leur consience, leur monde » (LEFEBVRE, 2000, p. 83).

47 Texto original : «L'homme est sa propre creation [...] ». (LEFEBVRE, 1986, p. 98).

48 Texto original : «la pratique spatiale, qui englobe production et reprodution, lieux spécifiés et ensembles spatiaux propes à chaque formation sociale, qui assure la
} 
Diante do exposto, como tomamos a noção de produção do espaço na análise da realidade metropolitana fluminense? Retomando o trecho acima, primeiramente a tomamos como princípio interpretativo para a compreensão dessa "relativa coesão". Mas também, e principalmente, a tomamos como possibilidade explicativa das contradições que se reverberam nas continuidades e ressurgem nas rupturas. Se há uma coesão na conformação da aglomeração metropolitana fluminense, essa está para sua formação social, assim como sua formação social está para um movimento em nada estável, tampouco equilibrado - o da reestruturação (ou reestruturações) do espaço. Dizendo de outra maneira, se a produção do espaço social permite compreender uma certa incorporação dos atos sociais (LEFEBVRE, 2000), a reestruturação do espaço permite compreender o movimento dessa incorporação.

Cabe ainda, mais uma explanação sobre a acepção espacial do conceito de produção

A atividade produtora, ao mesmo tempo vital e social, dos
seres humanos, se exerce, pois, em vários níveis ou graus: a
produção material - a produção das relações sociais - a
produção dos princípios, ideias, categorias e "sistemas" (esta
formulação comporta ainda uma reserva importante:
trairíamos o pensamento de Marx se imaginarmos "níveis"
exteriores uns aos outros e mecanicamente superpostos; em
todos os momentos da formação econômico-social, o que
produz é atividade criadora dos seres humanos em grupo).
Os resultados desta produção, formas, funções, estruturas,
sistemas ou ainda categorias e princípios, podem e devem
abstrair-se da atividade produtora, mas sem que esta
abstração seja jamais fetichizada, isolada e reificada. Os
momentos da atividade produtora se distinguem por meio da
análise, sem que esta tenha o direito de separá-los. A
incessante interação dialética, com as contradições que ela
cria e desenvolve historicamente, faz a profundidade e a

continuité dans une relative cohésion. Cette cohésion implique pour ce qui concerne l'espace social et le rapport à son espace de chaque membre de telle société, à la fois une compétence certaine et une certaine performance. Les représentations de l'espace, liées aux rapports de production, à 'l'ordre' qu'ils imposeent et par là, à des connaissances, à des signes, à des codes, à des relations 'frontales'. Les espaces de représentation, présentant (avec ou sans codage) des symbolismes complexes, liés au côté clandestin et souterrain de la sociale, mais aussi à l'art, qui pourrait éventuellement se définir non pas comme code de l'espace mais comme des espaces de représentation. 》 (LEFEBVRE, 2000, p. 42). 
riqueza da vida social. É o homem que produz e se reproduz, este homem total que cria a sociedade total, onde aí se perde e se reencontra, se aliena e se reconhece (posto que a sociedade só tem sentido para o homem e vice-versa). (LEFEBVRE, 1971, p. 104)

A acepção espacial do conceito de produção e, por isso, a noção de produção do espaço (social) nos fornece elementos teóricos para buscar no conceito de reestruturação uma acepção histórica, da história do espaço, em que as fases da reestruturação do espaço sejam tomadas como momentos da atividade produtora - conforme buscaremos expor mais adiante. Mas é preciso ainda, algumas adjunções sobre outros processos que se engendram no exercício dessa atividade criadora.

A urbanização. Claval nos aponta uma proposição instigante para a compreensão desse processo. No trecho a seguir, extraído do trabalho $L a$ logique des villes (1981), Claval apresenta três momentos da análise: a escolha de uma premissa, o caminho metodológico coerente à escolha anterior, os alcances e limites das abstrações sobre a realidade urbana

$\mathrm{O}$ autor sugere

Aqui gostaríamos de fazer um balanço da pesquisa sobre o que cria a cidade e a estrutura. Em vez de partir de uma definição formal da cidade, buscamos um princípio que nos faça entender tanto a unidade do fenômeno urbano, sua permanência ao longo da história e a multiplicidade de formas e civilizações urbanas. Partimos da ideia de que a cidade é uma organização projetada para maximizar a interação social: é então possível iluminar a localização dos centros, a formação de redes e a estruturação interna do espaço. Enfatizamos os problemas particulares na evolução das áreas construídas, o uso de mecanismos liberais de mercado - e indicamos, paralelamente, as dificuldades dos procedimentos de planejamento centralizado. [...]. Restrições espaciais e tecnológicas limitam as possibilidades de escolha e ação. A cidade ideal é sempre utópica. Mas isso não exclui a busca sob quais condições os requisitos contraditórios podem ser alcançados. (CLAVAL, 1981, p. 4 e $6)^{49}$.

\footnotetext{
49 Texto original: Nous voudrions ici faire le point sur les recherches consacrées à ce qui crée la ville et la structure. Au lieu de partir d'une définition formelle de la cité, nous avons cherché un principe qui fasse comprendre à la fois l'unité du phénomène urbain, sa permanence à travers I'histoire et la multiplicité des formes et des civilisations citadines. Nous sommes partis de l'idée que la ville est une organisation destinée à maximiser l'interaction sociale: il est alors possible d'éclairer la localisation des centres, la
} 
Claval considera a cidade e o processo de urbanização como fenômenos transculturais, mas que, por muito tempo, seus domínios não eram universais e sim restritos à espaços limitados. Essa primeira determinação da cidade e da espacialização do fenômeno urbano também carece de interpretações a partir das interfaces com os diversos sistemas culturais existentes desde a revolução neolítica - visto aqui como o período no qual o homem inicia o processo de produção (CHILDE, 1981). Dessa forma, a urbanização pode ser considerada como um dos processos mais antigos em curso na realização histórica da humanidade. Isso porque "a urbanização responde a uma necessidade de aprofundar e diversificar a vida social, para acessar intercâmbios e relacionamentos mais variados" (CLAVAL, 1981, p. 31). Considerando esse princípio interpretativo, partimos da premissa de que os demais processos socioespaciais, de natureza política, econômica e cultural, podem ser compreendidos na sua relação com o processo de urbanização mesmo que esse se realize em ritmos diversos e com características distintas nas diversas sociedades (CLAVAL, 1981).

As formas, as funções e as estruturas urbanas testemunham as fases de mutação, transformação e ruptura das sociedades enquanto totalidade histórica; mas não como um reflexo, e sim como produto das possibilidades e contradições das relações socioespaciais. Claval nos proporciona um mergulho profundo na própria história humana, ao problematizar a cidade como uma organização espacial destinada a maximizar a interação social (CLAVAL, 1981). Essa abordagem parece sugerir que a investigação e a análise da cidade, do fenômeno urbano e

formation de réseaux et la structuration interne de l'espace. Nous avons insisté sur les problèmes particuliers que suscite, dans l'évolution des zones construites, le recours aux mécanismes libéraux du marché - et nous avons indiqué, en parallèle, les difficultés auxquelles se heurtent les procédures centralisées de planification. [...]. Les contraintes spatiales et technologiques limitent les possibilités de choix et d'action. La cité idéale est à jamais utopique. Mais cela $n^{\prime}$ interdit pas de rechercher dans quelles conditions un optimum conciliant des exigences contradictoires pourrait être atteint. (CLAVAL, 1981, p. 4 e 6$)$.

50 Texto original: «l'urbanisation répond à un besoin d'approfondissement et de diversification de la vie sociale, au souci d'accéder à des échanges et à des relations plus variées. 》(CLAVAL, 1981, p. 31). 
das transformações socioespaciais ocorridas no contexto do processo de urbanização são tão amplas quanto as possibilidades históricas da realidade, ou seja, a temática se renova conforme a sociedade se realiza.

A premissa assumida por Brenner, em suas Teses sobre a Urbanização (2014), é a de que a urbanização não é um fato circunscrito em um local, escalonada em diferentes pontos mais ou menos conectados. A urbanização é a territorialização do capital e por isso é uma realidade manifesta pela combinação de processos a partir dos quais o urbano é produzido em uma escala planetária (BRENNER, 2014). Para o autor, "é possível colocar a investigação sobre a urbanização [...] no epicentro analítico da teoria urbana" (BRENNER, 2014, p. 23). Mas não só isso. Essa investigação deve considerar uma problemática contemporânea: a de que a urbanização estendida combina processos que resultam e facilitam no desenvolvimento do urbano e na extensão desigual do processo de destruição criativa capitalista

Desde muito tempo, as formas capitalistas de urbanização implicam processos de destruição criativa: as infraestruturas produzidas socialmente para a circulação de capital, a regulação estatal e a luta sócio-política, assim como os cenários socioambientais, sofrem as tendências de crises sistêmicas e se reorganizam de maneira radical. As aglomerações urbanas são somente um dos muitos lugares socioespaciais estratégicos onde se desdobraram esses processos de destruição criativa durante a geo-história do desenvolvimento capitalista. [...] O que sustenta em maior medida a problemática contemporânea da urbanização não é a formação de uma rede mundial de cidades globais ou uma única megalópole universal, mas a extensão desigual desse processo de destruição criativa capitalista em escala planetária. (BRENNER, 2014, p. 22)

Para Brenner esse processo de destruição criativa também pode ser compreendido pelos termos implosão-explosão, empregados conforme Lefebvre no livro A Revolução Urbana. Nas palavras do autor

Essa dialética de implosão (concentração, aglomeração) e explosão (extensão do tecido urbano, intensificação da conectividade interespacial em diferentes lugares, territórios 
e escalas) é um horizonte analítico, empírico e político essencial para qualquer teoria crítica de urbanização nessa primeira parte do século XXI. (BRENNER, 2014, p. 20)

Brenner alinha-se à Lefebvre em defesa de uma teoria urbana que "identifique $o$ caráter incessantemente dinâmico e criativamente destrutivo do 'fenômeno urbano' sob a ordem capitalista" (BRENNER, 2014 , p. 12). Esse processo de destruição criativa pode ser considerado, na perspectiva de Brenner, como absorção de tendências de crises sistêmicas e combinando o processo de reestruturação e 0 de expropriação ao desenvolvimento espacial desigual. Assim também Antunes (2000) afirma que essas tendências são, em verdade, respostas do capital à sua crise estrutural e que acentuam os elementos destrutivos constitutivos na lógica de reprodução do capital e nos seus padrões de dominação.

$\mathrm{Na}$ sua fase mais contemporânea, subvertendo formas espaciais anteriores, a urbanização, segundo Carlos (2015), realiza-se no movimento da produção e na reprodução do espaço, sob o domínio do urbano como momento da acumulação capitalista. A autora sinaliza que dessa realização, considerando movimento e momento, novos conteúdos podem ser sinalizados, por exemplo:

- A desconcentração do setor produtivo e a acentuação da centralização do capital na metrópole;

- A mudança das atividades do setor de serviços com a preponderância do financeiro e de serviços diferenciados e precarizados;

- O aparecimento de novos setores econômicos, tais como o turismo e lazer acompanhando os negócios financeiros;

- A realização de políticas públicas que dão atenção especial à produção do espaço em determinados setores e em determinadas áreas da metrópole com a criação de infraestrutura e alterações nos usos e funções dos lugares a partir de mudanças de zoneamento, 
'reparcelamento' do solo urbano, políticas de intervenção espacial através da realização de operações urbanas e da chamada requalificação de áreas - principalmente centrais - por meio de parcerias público-privadas. (CARLOS, 2015, p. 27).

Em relação ao primeiro exemplo, destacamos, no caso do Rio de Janeiro e especialmente com base no capítulo anterior, que a desconcentração do setor produtivo tem proporcionado o fortalecimento de uma "estrutura oca" resultado de uma desindustrialização relativa no que tange uma cadeia complexa e estruturante, acentuando ainda mais e sobretudo, a centralização do capital na Metrópole Rio. O segundo exemplo, apontado por Carlos, pode ser verificado retomando e relacionando os dados da tabela $6 \mathrm{com} \circ$ gráfico 3, apresentados no capítulo anterior, a partir dos quais é possível verificar a preponderância das atividades do setor de serviços e a precarização do trabalho como formas destrutivas veemente criativas no urbano sob a determinação da lógica de produção capitalista - do espaço e das relações sociais de produção. Os dados mencionados dizem, que na cidade do Rio de Janeiro, $51,2 \%$ do número total (2.381.304) de empregos formais estão no setor de serviços. Nas municipalidades metropolitanas de Niterói, Duque de Caxias e São Gonçalo esse percentual é, respectivamente, $57,8 \%$ (de 179.847 ), $39,3 \%$ (de 156.818 ) e $39,8 \%$ (de 115.129).

Em Duque de Caxias e em São Gonçalo, esse percentual decai em relação ao Rio de Janeiro e a Niterói. Atribuímos isso ao fato de que nessas espacialidades os serviços não são tão diferenciados, no que se refere à qualificação e especialização técnicas do trabalho e também ao papel dessas espacialidades na engrenagem da reprodução do espaço urbano no contexto metropolitano fluminense. Sobre a primeiro fato, a renda per capita declarada pelos entrevistados em São Gonçalo sugere a inferência, pois dos $43 \%$ que possuem renda, $28 \%$ não ultrapassam o montante de dois salários na composição de seus proventos, sendo essa 
renda extraída, quando considerada a ocupação formal, do setor de serviço seguido do setor de comércio. Sobre o último fato, a tese de que a metrópole é condição geral da produção e que por isso impõe uma determinada configuração espacial (CARLOS, 2015) ao processo de reprodução, servi-nos como premissa valiosa quanto as exigências teóricas que se impõe à compreensão da realidade metropolitana fluminense - ainda sobre esse último aspecto esboçaremos argumentos nos próximos itens considerando São Gonçalo.

Retomando os exemplos dados por Carlos acerca dos novos conteúdos da urbanização, o terceiro exemplo refere-se ao advento de novas frentes de reprodução ampliada e circuitos do capital, tais como o turismo e o lazer ${ }^{51}$. Os negócios desse setor econômico realizam-se, elementarmente, em duas dimensões da prática social, a dimensão espacial e a dimensão econômico-financeira. Para Cruz (2003) o turismo urbano é, sem dúvida, a modalidade predominante no mundo e as cidades e metrópoles são a mediação mercadológica mais promissoras para o setor. No que se refere ao lazer, para Cruz, esse "foi transformado em necessidade para as sociedades contemporâneas" e essa necessidade foi "criada pelo modo de produção capitalista como mais uma forma de apropriação do tempo total do trabalhador" (CRUZ, 2003, p. 38).

Aprofundando ainda mais esse conteúdo da urbanização contemporânea, Padilha (2003) sugere que o shopping center, no contexto das cidades e metrópoles brasileiras, são o melhor exemplo do lazer reificado ou do lazer-mercadoria. Para a autora, esses equipamentos urbanos possuem duas dimensões perspicazes às estratégias do capital no que se refere à reprodução das relações sociais de produção: a sociabilidade e a privatização. A autora também acrescenta que 0 aumento da figuração do shopping center como equipamento de lazer nas

\footnotetext{
${ }^{51}$ Ratificamos a importância desse tema para a compreensão da produção do espaço na contemporaneidade e quanto sua abordagem vem sendo ampliada. Entretanto, usamos nos argumentos aqui apresentados as considerações de CRUZ (2003) e PADILHA (2003), certos de que as referências são muito mais profusas e o tema muito mais complexo.
} 
cidades e metrópoles brasileiras repousa no fato da inexistência ou ineficiência dos espaços públicos de lazer enquanto políticas sociais, o que favorece não só a uma forma de sociabilização do consumo e a privatização do lazer, como também reforça a segregação socioespacial tão característica da realidade urbana brasileira.

A produção capitalista do espaço e da cidade legitima a propriedade privada e reforça as contradições entre as diferentes classes sociais. Esse conflito tem sido mais intensificado e menos mediado através da atuação do Estado e de seus instrumentos legais contribuindo para a construção de "novos espaços" ou "novas raridades". Segundo Carlos a condição de raridade do espaço possui três fundamentos: a existência da propriedade privada do solo urbano; a centralidade do capital e das novas atividades econômicas; o grau de ocupação da área no conjunto do espaço da metrópole. Se observarmos a tabela 8 , poderemos ampliar a compreensão da produção do espaço urbano a partir das contribuições de Cruz, Padilha e Carlos. 
Tabela 8 - RJ: número de shoppings centers, por município (2018)

\begin{tabular}{ccc}
\hline Município & Construído & Projeto Imobiliário \\
\hline Rio de Janeiro & 40 & 1 \\
São Gonçalo & 3 & 1 \\
Niterói & 3 & - \\
Duque de Caxias & 3 & - \\
Nova Iguaçu & 2 & - \\
Itaboraí & 1 & - \\
São João de Meriti & 1 & - \\
Itaguaí & 1 & - \\
Maricá & - & 1 \\
Petrópolis & 3 & - \\
Cabo Frio & 2 & - \\
Campos dos Goytacazes & 2 & - \\
Nova Friburgo & 2 & - \\
Resende & 2 & - \\
Angra dos Reis & 1 & - \\
Macaé & 1 & - \\
Volta Redonda & 1 & 3 \\
Teresópolis & 1 & - \\
& 69 & - \\
\hline
\end{tabular}

Fonte: Associação Brasileira de Shopping Centers - ABRASCE.

Elaboração: Juliana Luquez

No estado do Rio de Janeiro há, até a ano de 2018, 69 shoppings centers $^{52}$ construídos e 3 projetos imobiliários em desenvolvimento. A aglomeração metropolitana fluminense comporta 54 desses equipamentos (estando a maior parte localizada na cidade do Rio) e receberá mais 3 nos próximos anos. Em São Gonçalo, o primeiro desses equipamentos foi inaugurado em 2004, o segundo em 2010 e o terceiro em 2013 e o quarto ainda não tem data de inauguração, mas já tem endereço: Avenida Jornalista Roberto Marinho, esquina com a Estrada do Menezes, bairro Alcântara (imagem 13).

52 Classificados pela ABRASCE de acordo com os padrões internacionais estabelecidos para a categoria. 
Imagem 13 - São Gonçalo: localização dos três empreendimentos comerciais do tipo shopping center e da área onde será erguido o quarto, o Alcântara Plaza Shopping, com 210 lojas e $30.405 \mathrm{~m}^{2}$ (2018)

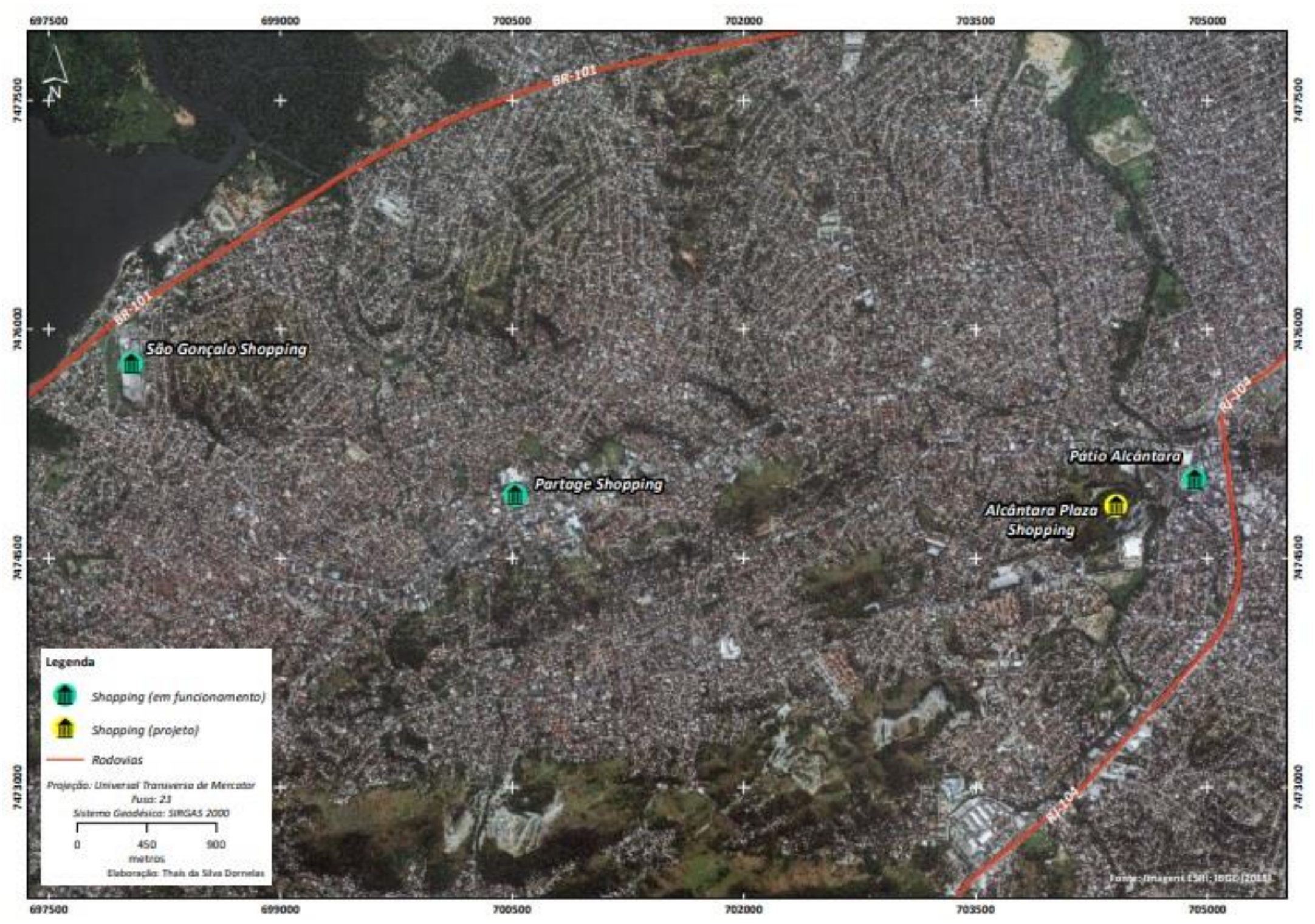


Os anos de inauguração desses empreendimentos sugere que eles estão inseridos nesses novos conteúdos da urbanização brasileira, considerando o contexto metropolitano, pois o shopping center como um condomínio comercial é um produto imobiliário que data da década de 1960, expandindo-se nos anos 1980 e popularizando-se no século XXI como espaços privados de acesso gratuito ao consumo de objetos e de entretenimento destinados, não originalmente, as classes econômicas C ( 3 a 5 salários mínimos) e D (1 a 3 salários mínimos) ${ }^{53}$.

Tudo torna-se mercadoria - o espaço fragmentado, inclusive. E o circuito do capital pelo processo de valorização do espaço realiza-se e encontra seus limites no processo de urbanização. A extensão de novas formas do capitalismo no espaço construído dá o sentido daquilo que Carlos chama de "raridades do espaço". Essa raridade é sempre orquestrada pelos interesses do capital no processo de dominação que hierarquiza os espaços privilegiados (os centros) acima dos espaços defraudados (periferias), partindo o espaço em fragmentos que são vendidos no mercado e servem de suporte à reprodução das relações sociais de produção (BOTELHO, 2007).

O quarto e último exemplo acerca dos novos conteúdos da urbanização, tomados a partir de Carlos, aprofunda ainda mais o aspecto acima mencionado. A produção do espaço e as mudanças de zoneamento, parcelamento, requalificação de áreas por meio da intervenção do Estado como agente ao mesmo tempo cúmplice da dominação e dos compromissos de classe e interessado na reprodução ampliada do capital no espaço urbano. O mapa 6 apresenta o zoneamento adotado pela Prefeitura Municipal de São Gonçalo, desde o Plano Diretor de 2009 e vigente até os dias atuais. De acordo com o zoneamento adotado, a implantação dos equipamentos urbanos de lazer privado, como os shoppings centers, o primeiro (2004) está localizado na área que se institucionalizou

${ }^{53}$ Classes econômicas, segundo o IBGE. 
como zona de dinamização (ZDI), o segundo (2010) e o terceiro (2013) foram implantados na zona de urbanização consolidada (ZUC1), o projeto imobiliário do quarto shopping center (ainda sem data de lançamento) será também construído na zona de urbanização consolidada.

Essa constatação nos leva a inferir, a partir de Carlos, que a condição de raridade do espaço em uma área consolidada de urbanização reforça os efeitos dos processos de homogeneizaçãofragmentação-hierarquização do espaço, quer na Metrópole Rio ou em sua aglomeração periférica. O espaço da homogeneização não tem, em si, nada de homogêneo, já nos salienta Lefebvre, posto que, "ele contém e unifica de maneira constrangedora fragmentos ou elementos dispersos" ${ }^{\prime 54}$ (LEFEBVRE, 2000, p. 355).

54 Texto original: «il [l'espace] contient et unifie de façon contraignante des fragments ou éléments dispersés » (LEFEBVRE, 2000, p. 355). 
Mapa 6 - São Gonçalo: zonas de estruturação urbana proposta pelo Plano Diretor (2009 - 2018)

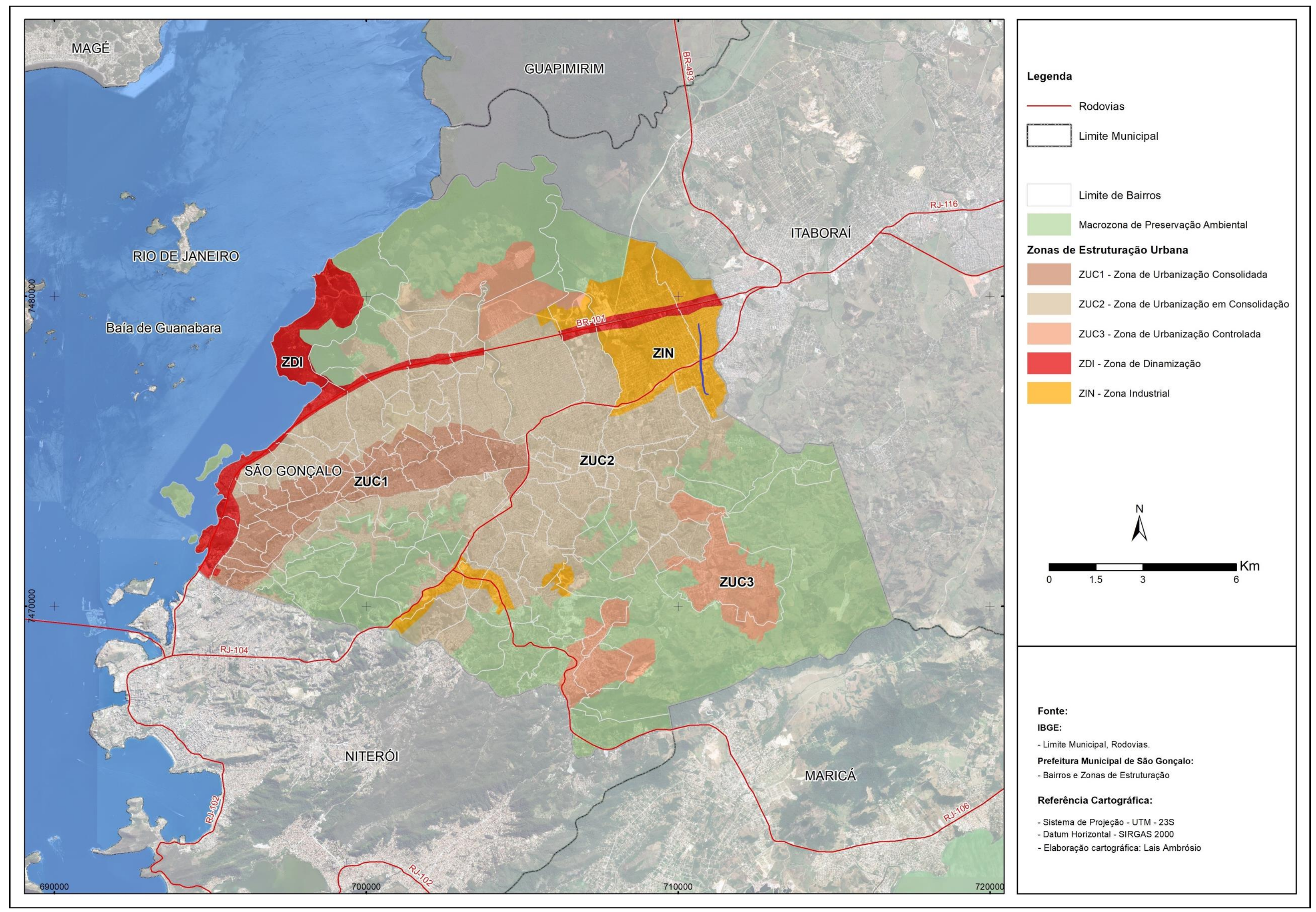


São Gonçalo, torna-se uma condição rara do espaço metropolitano, sendo, ao mesmo tempo, condição periférica de reprodução social. São Gonçalo em pedaços, serve de mercadoria ao setor imobiliário e álibi à reprodução do capital sob a hegemonia do financeiro; esses fragmentos são hierarquizados a partir de sua relação com o centro e com as ausências da periferia (sejam essas relações escalonadas a nível intra ou interurbano).

Esse zoneamento nos sugere também o circuito do capital na produção do espaço em São Gonçalo. Uma vez que através de instrumentos legais de intervenção espacial é possível identificar os eixos intraurbanos de drenagem de investimentos na forma de capital fixo com vista a mover a engrenagem da valorização do espaço e das continuidades perversas que determinam os compromissos sociopolíticos entre as classes e o padrão de dominação no atual modo de produção. Se o "espaço é condição, meio e produto da reprodução social [e] a acumulação do capital se realiza através da reprodução do espaço urbano" (CARLOS, 2015, p. 25), as formas destrutivas circunscritas no movimento dessa realização renovam-se e aprofundam as contradições entre espaço e sociedade.

Ainda em relação ao mapa 6, as zonas de urbanização consolidada (ZUC1), em consolidação (ZUC2) e controlada (ZUC3) são, em verdade, formas espaciais legitimadas pelo Estado dessa ação criativamente destrutiva do capital que ao mesmo tempo que expande seus domínios produzindo seu espaço, expande também suas contradições e reforça a luta de classes por interesses antagônicos: territorialmente dispersa, espacialmente fragmentada, socialmente segredada e politicamente constrangida. Na ZUC1 é possível verificar um constante processo revalorização imobiliária de áreas centrais: nessa área encontram-se quatro dos cinco bairros cujo o $\mathrm{m}^{2}$ é o mais caro de São Gonçalo. Se na ZUC1 é possível falar de raridades espaciais; na ZUC2, podemos falar de espacialização da integração dispersa da forma urbana, isso porque, essa 
grande mancha periférica está integrada à realidade urbana e metropolitana pelas relações de trabalho, de mobilidade e consumo, mas conformada territorialmente não em eixos conexos, mas em raios de dispersão da aglomeração que assenta em pontos cada vez mais longínquos a população de massa, não só intensificando a segregação como expropriando-a das possibilidades urbanas.

$A$ ZUC3, referem-se às zonas de ocupação próximas às Áreas de Proteção Ambiental (APA) ou de interesse turístico-ambiental; as ZDI e ZIN apresentam condições potenciais ao desenvolvimento econômico possível pela integração territorial a partir de uma das rodovias mais importantes do país, a BR-101; contudo toda a área à norte da BR-101 está sob o controle de uma das maiores facções criminosos do Brasil. $O$ Comando Vermelho atua fortemente em parte significativa do espaço parcelado pelo poder público, diminuindo ainda mais as chances de apropriação do espaço pela população pobre - contribuindo ainda mais com os interesses privados de securitização e privatização do espaço produzido socialmente. No que se refere ainda as zonas ZDI e ZIN, parte do potencial dinâmico e produtivo foi solapado devido as ingerências políticas no que concerne à instalação do Complexo Petroquímico do Rio de Janeiro (COMPERJ), iniciada em 2008, previsto para 2014 e ainda hoje sem rumo.

Por isso, o mecanismo de reestruturação do espaço é tão importante às estratégias de reprodução do capital, pois qualquer que seja a conformação espacial, essa é volátil, momentânea e pode ser recombinada mediante processos outros. Para além do espaço estruturado, defendido por Castells (2014), defendemos um movimento do espaço, apreendido a partir do processo de reestruturação: a reestruturação torna-se, mediante às contradições do capital, o seu maior álibi. Esse álibi encontra sentido na forma de espaço-mercadoria e se materializa pelos sentidos do trabalho produtivo (aquele capaz de gerar valor de troca e produzir mais-valia), é quando a problemática das 
relações sociais de produção tornar-se, na sua essência, espacial (CARLOS, 2011).

A problemática do espaço insere-se, atualmente, como uma importante referência analítica para as discussões acerca da questão urbana e da transição metropolitana. A partir dessa virada, a análise do processo de urbanização passa a incorporar as novas formas de expansão urbana (lógica topográfica) e a ampliação das redes de comunicação e informação (lógica topológica) ${ }^{55}$ na (re)configuração e (re)composição dos territórios: a metropolização do espaço (LENCIONI, 2017). O avanço teórico na investigação e na interpretação da realidade urbana e metropolitana deu-se também em prol de uma compreensão sobre os arranjos econômicos, seus agentes, suas ações e as lógicas de todo esse emarando de interesses que inflama a problemática espacial no que se refere ao espaço enquanto meio, condição e produto das relações sociais.

Claval considera que "a metropolização é a novidade essencial, pois ela testemunha o fim das rígidas estruturas regionais do passado próximo, mostra que fatores de regionalização da economia não faltam" (CLAVAL, 2005, p. 32) ${ }^{56}$. Não é de nosso interesse aqui, trilhar os caminhos da economia espacial como ponto de partida à problemática do espaço a partir da análise do planejamento urbano e do desenvolvimento regional, como o fez Santos (2007). Porém, esse autor nos fornece uma crítica

\footnotetext{
55 LENCIONI nos fornece uma importante contribuição para uma análise multiescalar que considere tanto a densidade territorial e como as redes de interação e integração dos lugares a partir da compreensão da lógica topológica e da lógica topográfica. Para a autora, a lógica topográfica "está relacionada à distância territorial entre os lugares e tem como referência a rede de infraestrutura de circulação. A distância, nesse caso, corresponde a um intervalo de espaço e de tempo entre dois lugares e dois instantes, medido em termos de superfície do terreno e de tempo de percurso. Entre dois lugares, A e B, por exemplo, a distância é de 5 quilômetros e de 10 minutos. A lógica topológica, por outro lado, insere a distância numa lógica virtual possibilitada pela revolução da informática e das comunicações. Nesse caso, a distância entre A e B é medida apenas em intervalo de tempo dos fluxos imateriais e, no seu limite, pode chegar à instantaneidade, anulando-se o intervalo e, consequentemente, a própria distância". (LENCIONI, 2011, p. 143).

56 Texto original: «la metropolisation constitue la nouveauté essentielle" [elle] "témoigne de la fin des structures régionales rigides d'un passé proche, mais montre que les facteurs de régionalisations de l'économie ne manquent pas" » (CLAVAL, 2005, p. 32)
} 
contundente e uma proposta analítica das formas geográficas como mecanismos de expansão do capital através de condições históricas, lógicas econômicas e ações dos atores hegemônicos no espaço sob a ideologia do planejamento - essa ideologia que sustenta projetos que destroem e constroem coisas no espaço. Para Santos a combinação de intenções e mecanismos de expansão do capital dirigiu-se exclusivamente à materialidade de formas geográficas para esse fim e, "embora o ritmo de construção seja bastante lento, o de destruição e de expropriação segue a plena velocidade" (SANTOS, 2007, p. 197).

Nesse sentido, ao analisar a conformação espacial como resultado do estabelecimento de condições gerais de produção no território paulista, Constantino (2017) defende que a conformação complexa da cidaderegião São Paulo, considerada em sua análise como o território urbano mais vantajoso em termos locacionais para a reprodução do capital, justamente pela alta concentração e diversidade de formas geográficas, tem essas formas condição de valorização do espaço mediante potencial de alta fluidez dos fluxos. Um forte argumento de Constantino, é que o constante movimento de revalorização do espaço com o objetivo de garantir vantagens locacionais para a instalação de empresas pode também chegar a máxima da oneração a ponto de comprometer os lucros dos capitalistas e é nesse momento que as cidades e as áreas metropolitanas, já consolidadas como espaços de maior concentração de condições gerais de produção, passam a um outro patamar do processo de urbanização.

A necessidade de condições gerais de produção adequadas ao modelo fordista passou a nortear a ação estatal que se incumbiu de oferecê-las para a reprodução do capital. Um processo ainda mais intenso de urbanização do espaço [...] passou a direcionar a conformação das metrópoles fordistas e estendeu as condições gerais de produção para uma área ampliada territorialmente, mas ainda limitada pela tecnologias de transporte e de comunicação, que não permitiam maior distância entre as diversas atividades [...]. A extensão [das metrópoles] permitiu que aparececem, no seu interior, vários centros ligados por uma rede hierárquica 
de fluxos, da qual o capital, fundamentado na produção, tira proveitp para reproduzir-se. O espaço urbanizado começou a interessar ainda mais à reprodução capitalista porque reunia a conjuntura necessária para produzir valor. [...] A concentração de condições gerais em determinada área significou também a deposição de mais valor no espaço, o que alçou à categoria de meio de produção [...]. (CONSTANTINO, 2016, p. 22)

O momento em que a urbanização, fortemente comprometida com o modelo econômico de desenvolvimento, abre caminhos para a dispersão das formas geográficas, esse movimento abarca conteúdos complexos (conforme anteriormente discorremos) que nos leva da forma geográfica à forma urbana.

A forma urbana. Mentalmente: a simultaneidade. Socialmente: o encontro (que reúne produtos e as atividades circunvizinhas), que, pela atualização e pela dessacralização, condensa a paisagem, obra do trabalho, forma imposta à natureza sobre um território. (LEFEBVRE, 1991, p. 192)

A forma urbana, simultaneidade e encontro, condensação e imposição, dá um sentido bem mais completo ao processo de metropolização do espaço à medida que este contribui para o adensamento das condições gerais de produção em um novo contexto de reprodução do capital, da acumulação fordista a acumulação flexível. Há, portanto, que se alcançar o entendimento de que

as condições gerais de produção criam possibilidades para a reprodução do capital, mas não são as causas da reprodução do capital porque o que determina a reprodução do capital são as relações sociais de produção. Diferença aparentemente sutil, mas que supera a coisificação implícita que se faz presente em muitas abordagens sobre os fatores de localização industrial. (LENCIONI, 2007 p. 8)

Passemos à leitura da forma urbana e a compreensão das relações sociais de produção que dão existência social e espacial à forma urbana na sua transição metropolitana. A nova forma urbana apresenta espaço menos marcados pela lógica industrial, investimentos imobiliários como fator pujante à mercantilização e multiplicação das centralidades que encontram lugar na condição de raridade do espaço. 
As imagens 14 e 15 podem contribuir para exemplificar a diferença sutil a qual se referiu Lencioni no trecho supracitado e a transição da forma urbana sob a determinação da racionalidade industrial para a forma urbana sob a determinação metropolitana.

Imagem 14 - Parque industrial em São Gonçalo (1930)

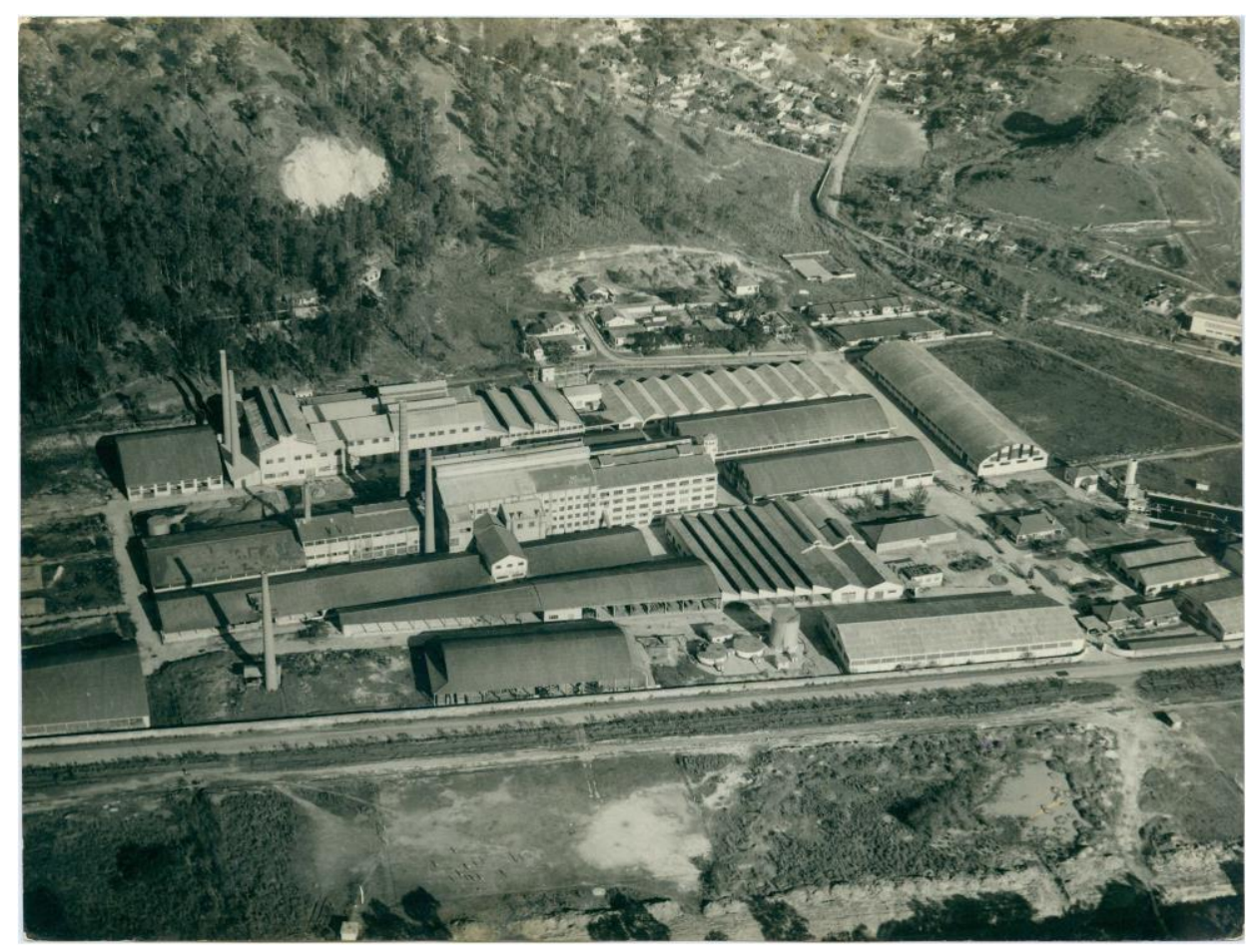

Fonte: Acervo dos municípios brasileiros, IBGE

O Parque Industrial de São Gonçalo, implantado na década de 1930, foi considerado entre as décadas de 1940 e 1950 uma das mais importantes áreas industriais do Estado do Rio de Janeiro. No Parque se localizavam fábricas com atividades diversificadas como a metalurgia, cerâmica, farmacêutica, produção cimento, de papel e gêneros alimentícios (VIANA, 2013). O título de Manchester Fluminense, conferido à São Gonçalo no mesmo período, fazendo referência à importante cidade industrial da Inglaterra, serve-nos de norte para compreender o conteúdo ainda dissolvendo-se nas relações sociais de produção contidas no espaço gonçalense, as quais não só construíram as funções sociais da e na cidade, como também permitiram a configuração da sociabilidade no 
contexto urbano.

Estamos nos referindo ao gráfico 5, apresentado no capítulo anterior. Os $12 \%$ dos entrevistados acreditam que a uma das maiores urgências à cidade é a atividade industrial, hoje, tal como no passado. Poucos tinham conhecimento da implantação do Condomínio Industrial e Empresarial de São Gonçalo - CIESG (imagem 15).

Isso se deve ao fato de que a produção do espaço da cidade de São Gonçalo, antes conduzida pelo ritmo do apito das fábricas (Wollwann, 2011), hoje se impõe sob formas novas, tanto no território quanto na sociabilização e nas relações de trabalho. O CIESG, resultado de parceria entre o governo municipal e a iniciativa privada, é um exemplo dessa ruptura. Localizado no bairro de Guaxindiba, foi instalado em 2011 visando atender as demandas empresariais atreladas a implantação do COMPERJ, em Itaboraí - interesses fortemente afetados com a crise política e financeira, da qual a Petrobrás se tornou símbolo do desmonte, em 2014.

Com a base produtiva totalmente ou praticamente apoiada no setor petro-gás-químico e na retomada da indústria naval, a economia fluminense, com destaque para as cidades de São Gonçalo, Itaboraí e Niterói, provou do inconveniente de ter apostado todo o potencial de desenvolvimento econômico e crescimento urbano em uma atividade falida antes mesmo de despontar. O CIESG não produziu os postos de emprego esperados por parte dos entrevistados que apontaram a indústria como uma urgência para São Gonçalo, embora o condomínio industrial conte com empresas de grande porte como, por exemplo, Logshore, B.Braun, Aliança, Siriso, Brasco, Kerneos, Votorantim, BR Petrobras, Schulz e Jotun. O grupo farmacêutico alemão B. Braun investiu $\mathrm{R} \$ 346$ milhões na construção de sua base produtiva no CIESG, a qual promete ser o maior da multinacional na América do Sul. ${ }^{57}$

${ }^{57}$ Prefeitura Municipal de São Gonçalo; Jornal o Fluminense. 
Imagem 15 - Área de implantação do Condomínio Industrial e Empresarial de São Gonçalo (CIESG). Destaque para a concepção espacial do projeto apresentada no canto superior direito, conforme a BR Logística. (2018)

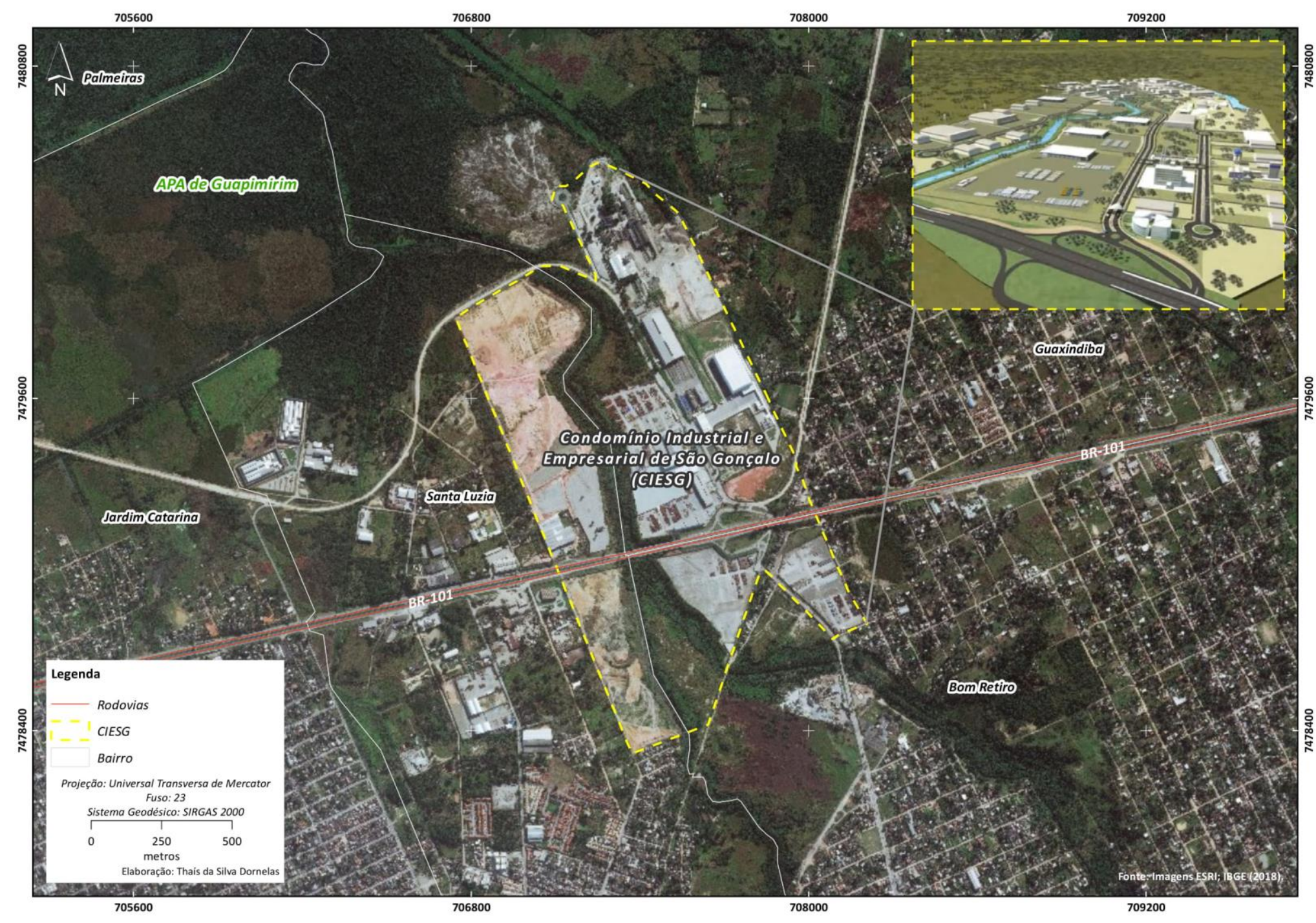


Tal empresa conta com apenas 1.600 colaboradores em todo o país, tendo sua atuação voltada para o setor produtivo de alta complexidade tecnológica, pelo qual o trabalho ganha novos sentidos (ANTUNES, 2000). O objetivo da implantação do CIESG e a política de atração de empresas para a localidade, ocupada por bairros populares e uma população de baixo poder aquisitivo, explicitam o foco na valorização do espaço. Finatti (2017) considera que as novas formas de aglomeração da indústria constituem-se como formas geográficas que caracterizam o movimento recente do capital imobiliário. Para o autor duas tipologias de aglomeração industrial podem ser tomadas como exemplo desse movimento, os condomínios industriais e os parques tecnológicos, "iniciativas que, no Brasil, marcaram a entrada dos promotores imobiliários no planejamento direto e execução de aglomerações industriais" (FINATTI, 2017, p. 186).

Além do mais, a infraestrutura disponível usada para captar e viabilizar a implantação do condomínio industrial no bairro de Guaxindiba, firmou-se apenas na proximidade com a BR-101, no trecho NiteróiManilha, e nos acessos a RJ-104. Toda a delimitação do CIESG está próxima a Área de Proteção Ambiental de Guapimirim (APA-Guapimirim), e mesmo assim, foram dispensados estudos de impacto (EIA/RIMA), dispensa essa que conduziu o Ministério Público Federal a mover uma ação civil pública58 contra o município de São Gonçalo e o Instituto Estadual do Ambiente (INEA).

Não só o ritmo, mudou também o conteúdo das relações sociais de produção. O modelo de acumulação fordista (imagem 14) que promoveu a cidade industrial e atribuiu lógicas racionais à base material sob a qual as relações de produção eram tramadas, hoje, em sua transição para um modelo de acumulação flexível, possível graças à movimentos reestruturantes (imagem 15). ${ }^{59}$

\footnotetext{
58 Sob o número 2012/51170006773.

59 Não iremos problematizar o debate acerca da lógica transformativa e especulativa do capital e nem o seu movimento transitório do fordismo à acumulação flexível. Cremos que Harvey (2011) já o fez de forma contundente e dessa contribuição teórica partimos.
} 
De acordo com Agnew (2008), a variação geográfica do crescimento econômico é cada vez mais local e regional dentro dos países e as articulações dos poderes locais servem, justamente, de mediação para a conformação dos poderes globais. Assim, fortalece-se a fragmentação territorial e ampliam-se as redes (material e imaterial) de integração econômica localizadas. Para o autor a principal novidade na atualidade dessa nova configuração do poder é o papel crescente de fluxos e das redes de integração do mundo pelo urbano. Os mecanismos territoriais dessa dinamização são evidentes nas cidades brasileiras, no âmbito de países onde as disparidades internas de rendimentos e de desenvolvimento econômico são cada vez mais marcantes, na medida em que algumas regiões aproveitam sua inserção nos circuitos globais do capital, enquanto outras ficam totalmente fora ou sofrem as nefastas consequências das mais convencionais estratégias de desenvolvimento.

2.1.1. São Gonçalo: desenvolvimento industrial e periferização, aspectos para perceber o movimento

A análise geográfica das dinâmicas territoriais e urbanas que se manifestam e configuram o espaço metropolitano do Rio de Janeiro, no qual a cidade de São Gonçalo se destaca a partir de suas características históricas, seu aproveitamento econômico, antes polo industrial, hoje de comércio e serviços; bem como os deslocamentos populacionais pendulares que ao longo de todo o processo de urbanização fluminense vêm apresentando novos estágios de integração à Metrópole Rio e novas articulações com o desenvolvimento interno da região, mas também com as lógicas externas do circuito de reprodução do capital - a hegemonia das finanças e a produção do espaço guardam relações cada vez mais intrínsecas.

Tomamos como referência, especialmente, a parte 2 de seu livro, intitulada $A$ transformação político-econômica do capitalismo do final do século $X X$, na qual o autor insere a perspectiva do movimento (tempo e espaço) na análise das práticas sociais em busca de caracterizar o período recente de desenvolvimento capitalista. 
São Gonçalo tem seu início ainda no século XVI, como sesmaria às margens do Rio Imboaçu (localizado no atual bairro de Zé Garoto). O processo de povoamento se deu a partir da construção da Igreja Matriz de São Gonçalo do Amarante que, por seus arredores, a ocupação urbana foi incentivada. Os bairros de Itaoca, Colubandê, Ipiíba, Engenho Pequeno e Gradim possuem lembranças de um passado colonial em São Gonçalo, com destaque para as fazendas e capelas ainda dos séculos XVII e XVIII.

Devido a sua localização geográfica, sua hidrografia com foz para Baia de Guanabara, o território de São Gonçalo ganhou infraestrutura portuária e a produção manufatureira que exportava produtos para a Corte foi intensificada. Em 1860, seu território já contava com 30 engenhos e 4 portos. A partir do final do século XIX e início do século XX, a articulação com a capital do estado do Rio de Janeiro fora bem mais acentuada, visto o processo de industrialização que o estado passou ao longo do século XX. Entre as décadas de 1940 e 1950, a instalação, em grande escala, de fábricas e indústrias em São Gonçalo, intensificou o processo de urbanização na cidade. Junto ao seu desenvolvimento industrial, a cidade de São Gonçalo passa por um impetuoso crescimento populacional. Uma vez que a atividade industrial se fortalecia, um grande contingente populacional ia sendo atraído para ser absorvido nesse setor e instalar-se nos bairros operários produzidos pelas companhias e empresas atuantes na região, além de fundar espaços populares de assentamentos precários por aqueles que produziam o espaço na informalidade de sua função social. A conformação espacial tornou-se, em São Gonçalo, cada vez mais inerente ao processo de divisão territorial das atividades produtivas e da reprodução social da classe operária fluminenses.

A prosperidade econômica anunciada e incentivada pelo poder público e usufruída pelos grupos hegemônicos regionais, nacionais e até internacionais, teve seu apogeu e declínio entre os anos 1930 a 1970 . O fechamento de várias unidades industriais localizadas no leste da Baia de Guanabara a partir dos anos 1980, principalmente em São Gonçalo, 
trouxe grandes transformações ao espaço urbano, mesmo em um cenário de estagnação econômica. Além do desemprego, do abandono dos espaços industriais e da degradação na paisagem urbana da cidade, o baixo desenvolvimento de infraestrutura, a ausência ou insuficiência de equipamentos urbanos compõem a lista previsível das circunstâncias que concorreram para agravar a posição periférica de São Gonçalo em relação ao Rio de Janeiro e a Niterói, à época, respectivamente, capitais federal e estadual.

Embora São Gonçalo tenha se tornado ao longo do século XX um grande polo industrial do estado do Rio de Janeiro, vale destacar que o seu desenvolvimento urbano sempre esteve aquém do das capitais. Suas infraestruturas de transporte, por exemplo, seguiu um padrão de interesses no que diz respeito ao desenvolvimento econômico e industrial do estado e não ao crescimento da cidade que, a partir da década de 40, se tornou expressiva: passando em três décadas de 85.521 (1940) para 420.271 (1970) e nas primeiras décadas de século XXI alcançando a marca milionária, sendo a segundo maior concentração populacional do estado do Rio de Janeiro.

Geiger (1956) descreve São Gonçalo considerando sua relação imediata com o Rio de Janeiro e atrela seu desenvolvimento urbano e econômico ao contexto fluminense de prosperidade liderado pela então capital federal. O autor também nos leva a sutileza da transição das relações de produção que opunham o rural e o urbano, tendendo ao urbano como condição de novas formas de acumulação, sendo para isso, necessário uma reestruturação do espaço - está que se fará perceber no próximo item.

São Gonçalo é na prática, um subúrbio do Rio de Janeiro, no qual fazendas e pomares foram e estão sendo loteados em benefício do crescimento urbano e da industrialização. A produção de cimento, papel, vidro, sardinhas, produtos químicos e matérias de construção são alguns dos ramos industriais deste importante município. Também aí, as empresas de ônibus têm se multiplicado, mantendo longas 
linhas de comunicação; o bonde e os trens suburbanos nas horas do 'rush' são outros veículos coletivos que servem à população. A área urbanizada é muito extensa, pois é grande a dispersão do casario pelas antigas fazendas loteadas. Neves é conurbada ao bairro de Barreto em Niterói (GEIGER, 1956, p. 47-70).

Através da descrição relacional feita por Geiger, conjecturamos que o processo de periferização, gestado ainda sob o domínio das ruralidades, manifesta-se como principal característica da desestruturação/reestruturação do espaço sob os novos rumos da produção. Se desde o início do processo de industrialização, que intensificou o crescimento urbano, segregou os citadinos em áreas socialmente definidas para sua reprodução, as políticas espaciais de desenvolvimento de infraestrutura, que sempre estiveram atreladas as questões políticas de fortalecimento econômico da Metrópole Rio, trouxeram agravantes no processo espoliativo a elas atrelado.

Essa situação consolidou as centralidades do Rio e de Niterói na aglomeração fluminense e rearranjou os fluxos e dinâmicas territoriais anunciadas pelo fato metropolitano sob novas relações sociais de produção. Com a criação do estado da Guanabara (1960), o fechamento das fábricas no contexto da crise econômica ${ }^{60}$ das décadas de 1970-80, a transição demográfica no bojo da consolidação do arranjo espacial metropolitano, a porção oriental da Baia de Guanabara tornou-se um exemplo pertinente do movimento de reestruturação do espaço ativado pelos processo de periferização-segregação-espoliação.

Oliveira (2003) compreende de maneira abrangente a complexidade das relações sociais de produção e os conteúdos da realidade urbana no contexto industrial que norteou a realização do capitalismo periférico no Brasil, sendo as cidades, conformadas sob a influência de dinâmicas territoriais metropolitanas, condição, meio e produto dessas relações.

60 Reforçamos que não usamos o termo crise de forma leviana. Aqui ratificamos, conforme o capítulo anterior, que as crises do Rio e de sua aglomeração precisam ser compreendidas no movimento de realização da sociedade fluminense, ou seja, pelas suas relações sociais de produção. 
A evidente desigualdade de que se reveste que, para usar a expressão famosa de Trotsky, é não somente desigual mas combinada, é produto antes de uma base capitalística de acumulação razoavelmente pobre para sustentar a expansão industrial e a conversão da economia pós-anos 1930, que da existência de setores "atrasado" e "moderno". Essa combinação de desigualdades não é original; em qualquer câmbio de sistemas ou de ciclos, ela é, antes, uma presença constante. A originalidade consistiria talvez em dizer que sem abusar do gosto pelo paradoxo - a expansão do capitalismo no Brasil se dá introduzindo relações novas no arcaico e reproduzindo relações arcaicas no novo, um modo de compatibilizar a acumulação global, em que a introdução das relações novas no arcaico libera força de trabalho que suporta a acumulação industrial-urbana e em que a reprodução de relações arcaicas no novo preserva o potencial de acumulação liberado exclusivamente para os fins de expansão do próprio novo. Essa forma parece absolutamente necessária ao sistema em sua expressão concreta no Brasil, quando se opera uma transição tão radical de uma situação em que a realização da acumulação dependia quase integralmente do setor externo, para uma situação em que será a gravitação do setor interno o ponto crítico da realização, da permanência e da expansão dele mesmo. Nas condições concretas descritas, o sistema caminhou inexoravelmente para uma concentração da renda, da propriedade e do poder, em que as próprias medidas de intenção corretiva ou redistributivista - como querem alguns -transformaram-se no pesadelo prometeico da recriação ampliada das tendências que se queria corrigir. (OLIVEIRA, 2003, p.59-60)

Se as relações sociais de produção, contidas no espaço, tecem-se entre rupturas e continuidades, esse espaço socialmente produzido também está vinculado ao movimento contraditório que não opõe processos velhos aos novos, o arcaico ao moderno, o centro à periferia, mas os realizam simultaneamente - por isso fragmentado e articulado (CORRÊA, 1993). À vista disso, consideramos o processo de metropolização fluminense como o momento da urbanização complexa que subordina tempos e espaços à novas articulações locais, regionais e globais, conectando territórios descontínuos e fragmentando territórios contínuos, ampliando as redes materiais e imateriais, reorientando escalas e processo socioespaciais. Em outras palavras, a metropolização constitui- 
se a fase recente de reestruturação do espaço no bojo das relações sociais de produção.

Lencioni (2017) identifica oito características da metropolização que são pertinentes na análise e na discussão da dinâmica da produção do espaço fluminense e na definição de suas particularidades, considerando diferentes momentos e fases. São elas:

Imagem 16 - Características da metropolização do espaço

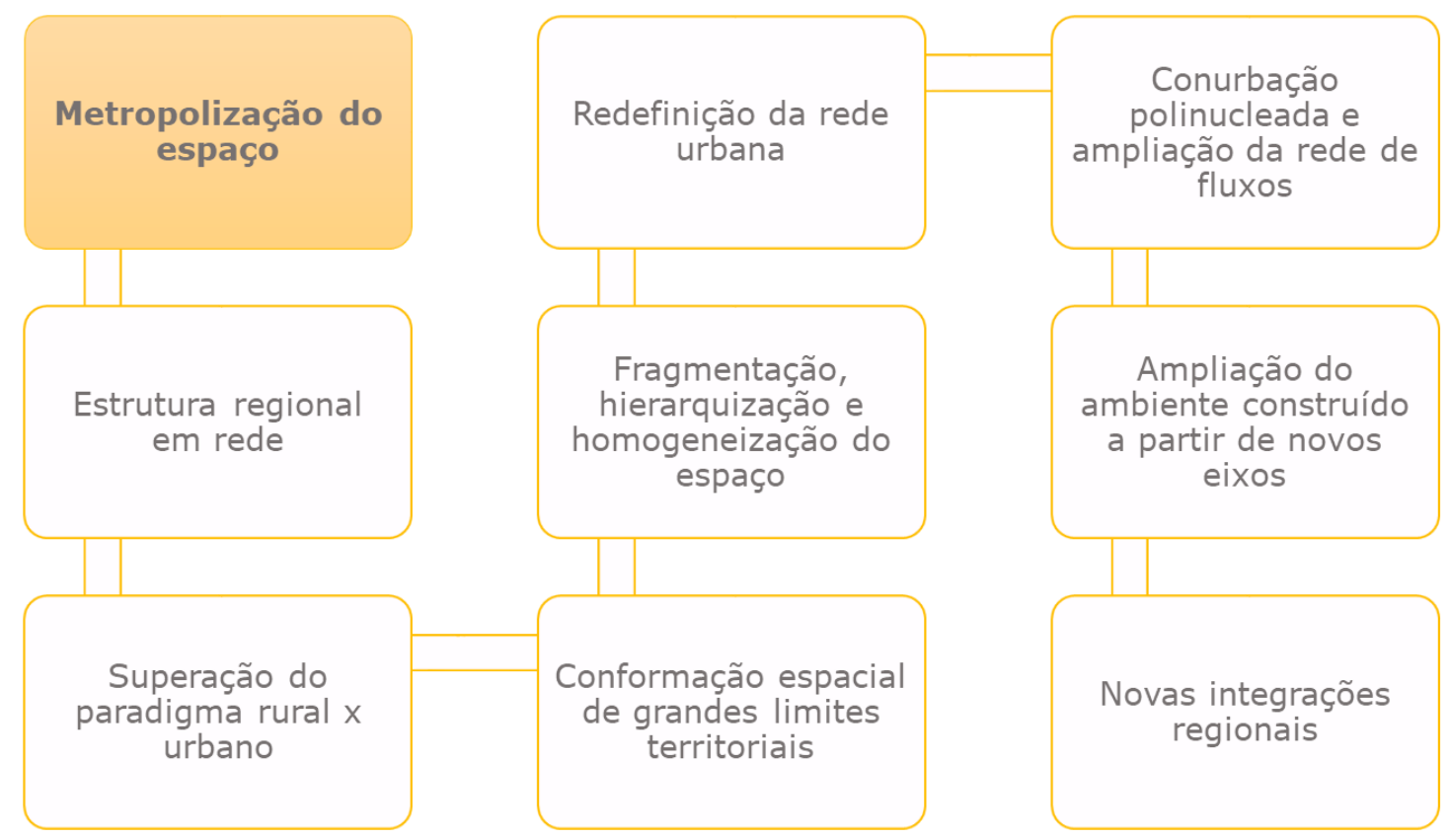

Elaboração: Juliana Luquez a partir de LENCIONI, 2017.

Mediante essas constatações fazem-se necessárias algumas observações quanto a metropolização fluminense.

Se a estrutura urbana tradicional transfigura-se devido a ampliação das redes de fluxos, o processo de urbanização passa a realiza-se na simultaneidade com 0 de regionalização. Em outras palavras, a urbanização produz transformações socioespaciais tão intensas que metamorfoseia territórios e regionaliza espaços (LENCIONI, 2017; SOUZA, 2017). Considerando as particularidades da metropolização fluminense, seria possível inferir que a aglomeração metropolitana fluminense se 
constitui em uma forma metropolizada da concentração?

Distantes de qualquer possibilidade de incoerência, respondemos positivamente a questão. Pois a forma metropolizada da concentração, tal qual se verifica do território do Rio de Janeiro, se refere a forma espacial da hierarquização da centralidade. Estando na cidade do Rio de Janeiro a concentração da gestão e do comando do capital e do território e dela, irradiando pelos eixos de expansão metropolitana, para as demais centralizadas da rede urbana conformada. A dinâmica territorial atribuída a esse movimento cria novas integrações regionais e altera a natureza das relações de cada parcela do espaço com as centralidades urbanas da região, reforçando a fragmentação e a homogeneização espaciais.

A dinâmica da mobilidade regional se intensifica mesmo com o baixo investimento em infraestrutura de transporte de alta capacidade. $\mathrm{Na}$ aglomeração metropolitana do Rio de Janeiro, o uso especulativo do solo nos acessos às rodovias BR-101, BR-116, BR-493, BR-40 e, na porção leste do território, às estradas RJ-104 e RJ-106, ao mesmo tempo que integram os fluxos também contribuem para uma conformação espacial de grandes limites regionais, consolidando eixos de expansão e anexando áreas ao processo de valorização do espaço. Em tempos de metropolização, o urbano e o regional tornam-se indivisíveis.

Isto posto, estabelecemos uma periodização a partir da qual pudéssemos posicionar nossa discussão teórica: o movimento de reestruturação do espaço, procurando o ponto de ruptura do fenômeno urbano na atualidade, mas refletindo sobre suas continuidades enquanto processo histórico. Ao apontar a centralidade do espaço na discussão que busca tornar mais inteligível o mundo moderno, Lefebvre propôs uma periodização da história: a era agrária, a era industrial e a era urbana (LEFEBVRE, 2008). Propomos uma periodização dos momentos do espaço circunscrevendo as fases do processo de reestruturação como potencial à leitura dos tempos do espaço ou do espaço de cada tempo sem dissolver a inteligibilidade da realização total da sociedade urbana (imagem 17). 
Imagem 17 - São Gonçalo: síntese dos momentos da urbanização e das fases de reestruturação do espaço

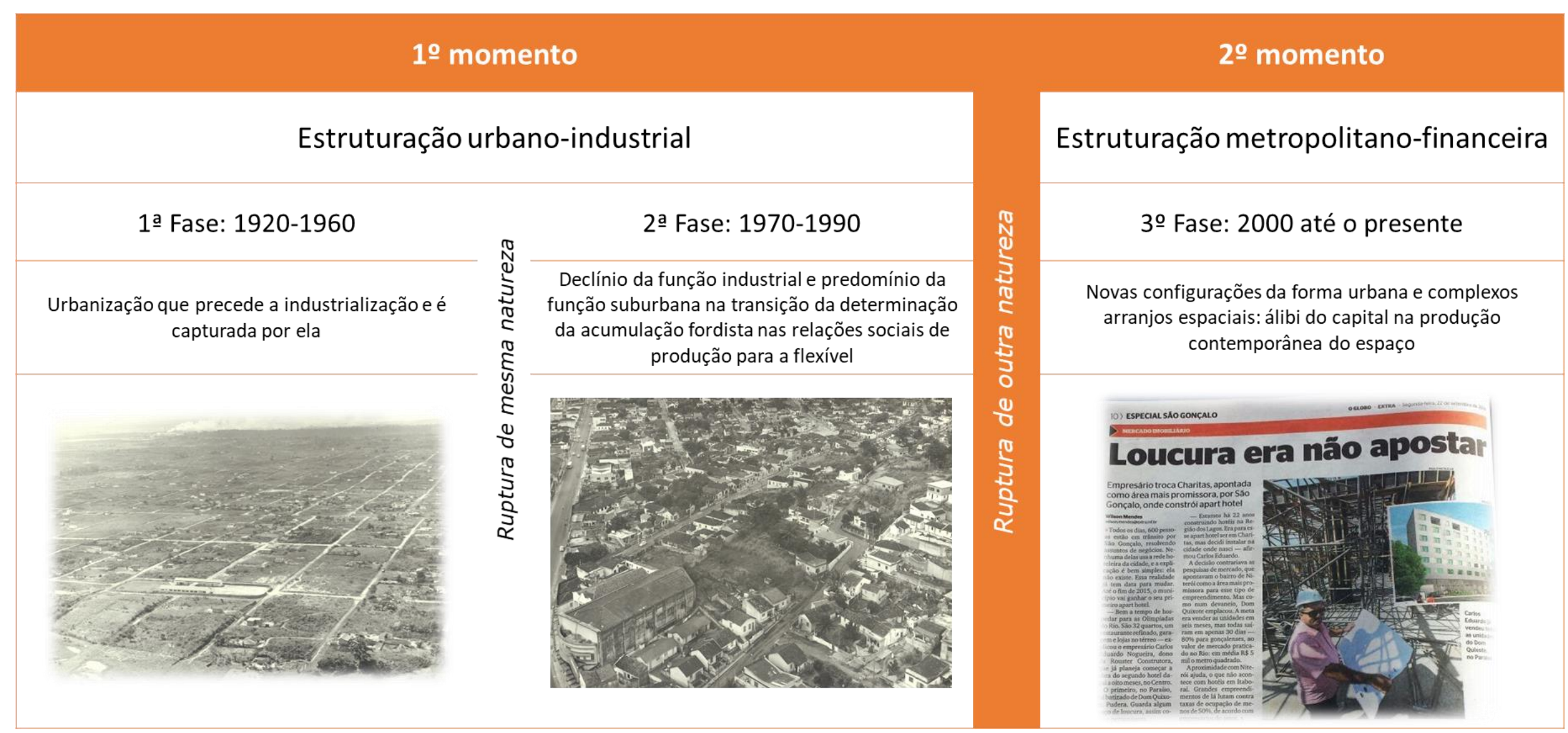

Elaboração: Juliana Luquez. 
Propomos uma análise espacial, considerando a periodização acima apresentada, a partir do conceito de reestruturação. Antes, não estamos a falar de uma estrutura social que explica uma certa organização ou ordenamento espacial. E sim de uma estruturação do espaço. É importante perseguir a autonomia do espaço - conforme apresentado a partir de Lefebvre no capítulo anterior.

O espaço $[\ldots]$, deixa a prática no modo de produção e reage a ela: espaço das estradas, meios de locomoção, mas também megacidades, periferias mal delimitadas, redes múltiplas que os ligam, fluxos de produtos, capital, ganhos, especulação em terra, várias atividades, bancos e promotores, que dominaram e exploraram o espaço assim produzido. (LEFEBVRE, 1986, p. 161) ${ }^{61}$

O conceito de reestruturação aqui apresentado não deve ser tomado como análogo ao de organização ou ordenamento do espaço. Isso porque, antes de apreendermos a reestruturação como um conceito ou categoria à análise espacial, a tomamos como um processo característico do movimento total da produção do espaço. Essa percepção de movimento não encontramos nos termos organização ou ordenamento, visto que, esses termos nos conferem um sentido de equilíbrio e estabilidade na dinâmica de realização da sociedade. Correríamos o risco de cristalizar sistemas e indeferir o movimento. Tudo que nossa análise não pretende como já destacamos outras vezes.

Nossa contribuição teórica acerca do conceito e do processo de reestruturação constitui-se como um salto metodológico da compreensão da produção do espaço a partir de Castells (espaço estruturado) e Giddens (dualidade da estrutura). Expliquemo-nos melhor. Para Castells (2014) a estrutura urbana constitui-se de elementos sistêmicos (econômico,

\footnotetext{
61 Texto original: «l'espace en même temps que la communication et l'information, sort de la pratique dans le mode de prodction et réagit sur elle: espace des routes, des moyens de locomotion, mais aussi des mégalopoles, des périphéries mal delimitées, des réseaux multiples qui les relient, des flux de produtis, de capitaux, de gains, de spéculations sur les terrains, des activités diverses, banque et promoteurs, qui ont dominé et exploité l'espace ainsi produit. » (LEFEBVRE, 1986, p. 161).
} 
político, ideológico), os quais moldam o espaço. Giddens (2013), as características de sistemas sociais "têm propriedades estruturais no sentido de que as relações estão estabilizadas através do tempo e do espaço". (GIDDENS, 2013, p. XXXV).

Nosso percurso metodológico propõe, justamente abandonar a análise sistêmica, partindo da premissa que o urbano não se estrutura/reestrutura, o urbano se realiza no espaço e pelo espaço. 0 espaço contém estruturações e reestruturações dado o movimento dessa realização do urbano que comporta, contraditoriamente, rupturas e continuidades nas relações sociais de produção. Passemos à essa abordagem. 


\subsection{Reestruturação: processo e conceito para a análise espacial}

Cada sociedade constitui-se em uma estrutura, em uma coesão ou coerência global. Todavia, é impossível atribuir um caráter definitivo a essa estrutura, que nem apresenta e nem se representa em um único nível ou em uma única dimensão. Sobre esse aspecto, Gurvitch (1971) insistiu que uma representação unitária pode ignorar as características de contínua recomposição e de equilíbrio precário, momentâneo, do qual participam todos os elementos do fenômeno social total - inclusive o espaço.

No âmago de qualquer estrutura (social, urbana) agem forças e tendências à desestruturação. Ao lado ou mesmo no seio de setores fortes, cada sociedade (agrária, moderna, industrial, urbana) tem seus fracassos e deficiências, suas lacunas. Sem isso a sociedade iria se manter estática para sempre. Sua história não se realizaria. As relações jurídicas, por exemplo, deram forma às relações de propriedade, estancando, momentaneamente, os impasses e limites à reprodução social. Da mesma forma, as instituições políticas foram as respostas às lógicas e estratégias de dominação, aquela da classe ou das frações de classe. O mesmo aconteceu com as ideologias. À estrutura também é atribuído o duplo processo de implosão-explosão e, assim, o perpétuo movimento de estruturação-desestruturação-reestruturação.

A reestruturação como conceito contribuiu para apreender processos espaciais proteiformes e relacionais. É comum que o conceito de reestruturação acompanhado de diferentes adjetivações (urbana, produtiva, urbano-industrial, imobiliária, metropolitana, etc) seja empregado (ou compreendido), grosso modo, como "novos usos" ou "refuncionalização". Ao discutir esse conceito à luz da noção de produção do espaço ampliam-se as perspectivas conceituais sobre a realidade contemporânea. Essa realidade, cada vez mais urbanizada, torna-se metropolitana; cada vez mais espacialmente complexa e conceitualmente 
obscura em termos explicativos. Pois já não mais os mesmos conceitos dão conta de representar os diversos processos. Muitas vezes, e a partir de agora cada vez mais, tem-se feito necessária uma tentativa de explicação do real simultaneamente a uma revisão do arcabouço teórico que herdamos, especialmente, entre anos 1970 e 1990 sobre os temas cidade e urbano, urbanização e industrialização, produção e reprodução do capital, metrópole e metropolização.

Nossa trilha buscou 1) perceber a contribuição do conceito de reestruturação para a compreensão da produção do espaço. Para isso, 2) realizamos um breve levantamento das adjetivações dadas ao conceito de reestruturação e a contribuição desse léxico conceitual para a compreensão das dinâmicas espaciais. Finalmente, 3) selecionamos quatro artigos desse levantamento bibliográfico a partir dos quais chegamos a uma questão de método: os usos e o sentido do conceito de reestruturação e a perspectiva metodológica da análise dizem muito sobre as respectivas adjetivações empregadas ao conceito.

Os dois primeiros passos estão considerados na primeira parte de item; ficando a segunda parte destinada à discussão estabelecida com as bibliografias selecionadas.

Nossa intenção é contribuir para uma discussão acerca do conceito de reestruturação através da consideração de suas diferentes fases e para uma reflexão dos meandros desse processo na dinâmica da produção do espaço da metrópole contemporânea. Tal aprofundamento teóricometodológico permiti-nos uma visão mais ampla das complexidades metropolitanas contidas no objeto desse trabalho.

2.2.1. Reestruturação: compreensão da produção do espaço e usos do conceito

Ao considerarmos a perspectiva do movimento e da totalidade, sob a perspectiva da interpretação da reestruturação do espaço, assumimos a 
possibilidade de periodização dos seus diferentes momentos a partir da definição de fases onde podem ser reunidas as características e conhecida a dinâmica específica dos elementos que variam e mudam a composição do espaço ao longo do tempo.

A definição de fases é também um meio de reconstituição do espaço em busca de compreendê-lo em sua totalidade, da gênese à evolução, refletindo já sobre suas tendências, que se encontram e se superam por processos que se materializam através das formas e das funções, por meio de estruturas. Neste sentido, pensar as articulações entre os níveis da realidade urbana se coloca como um desafio na análise da produção do espaço, seja no plano teórico-conceitual, seja na compreensão de sua realidade concreta e complexa.

As transformações socioespaciais tendem a ativar outros processos, acelerar ou romper com movimentos antigos. Contudo, as descontinuidades, provenientes de fases de rupturas entre um momento e outro, não varrem da paisagem urbana seus elementos constitutivos. Ao contrário, as continuidades testemunham o movimento dos processos socioespaciais, estando estas também inseridas no processo de produção do espaço através da conformação da paisagem urbana e aproximam-nos cada vez mais da compreensão da totalidade espacial, quando não encobertas pela análise das transformações recentes como se essas tais não tivessem uma herança histórica nas contradições do processo de produção do espaço.

Assim através da escolha do conceito de reestruturação, que em nossa perspectiva metodológica, implica nas noções de continuidade e ruptura, temos, respectivamente uma preocupação analítica: as transformações socioespaciais; a paisagem urbana como reveladora de absorções e superações dos elementos espaciais na sua relação com a realidade da sociedade urbana contemporânea; e as diferentes fases que caracterizam os momentos de mudança, qualitativa e quantitativa, do processo de produção do espaço metropolitano. 
A evolução urbana da cidade capitalista assume uma estrutura passível de processos dinâmicos e simultâneos, como o de reestruturação do espaço. A conformação da aglomeração urbana que se estende desde a metrópole até os seus subúrbios amplia a análise desses processos, permitindo considerá-los na reconstrução da realidade urbana e metropolitana. Admitindo que o subúrbio é, tanto quanto a cidade, lugar de contradição e reestruturação, lugar de produção e reprodução dos interesses das classes dominantes, lugar de formas e conteúdos que relacionam-se à dinâmica da vida urbana e à impõe um cotidiano; e o quanto o subúrbio metropolitano se relaciona com a própria metrópole, com seus elementos estruturantes e agentes sociais; a investigação das complexidades metropolitanas precisa considerar o arranjo espacial de sua expansão e atentar-se para a relação existente entre essas espacialidades e as formas, funções e estruturas que constituem o emaranhado das desestruturações e reestruturações da metrópole e de sua área de expansão.

Nossa abordagem tem se dado a partir da discussão do conceito de reestruturação inaugurado sob a lógica capitalista de produção do espaço da metrópole e de sua região. O conceito de reestruturação nos parece pertinente na investigação das transformações socioespaciais devido ao fato de ele em si se referir a um movimento em curso do processo de produção do espaço, a saber o movimento de estruturaçãodesestruturação-reestruturação. Este conceito também possibilita um diálogo com os conceitos de ruptura e continuidade, tomados aqui sob uma perspectiva histórica na análise socioespacial, através da qual o processo de produção do espaço aponta contradições e simultaneidades com outros processos espaciais que merecem ser considerados ao longo da pesquisa, sob pena de dissolvermos a realidade complexa das interações socioespaciais.

Esses processos produzem resultados a partir de elementos combinados. E o entendimento do conceito de reestruturação, como 
processo, permite-nos a conexão desses elementos. Considerando a continuidade como a "persistência das características inerentes a um determinado contexto" - conforme uma das acepções do Dicionário Houaiss - não há como descartar o movimento histórico do processo de produção do espaço a partir do movimento de estruturaçãodesestruturação-reestruturação. Tão pouco descartar as fases de ruptura nos seus diferentes momentos.

Nesse sentido o conceito de reestruturação possibilita o entendimento das transformações produzidas pelas dinâmicas dos processos socioespaciais contribuindo para a observação do momento em que o que está posto e funcionando, se desmonta e passa a funcionar de outra maneira ou não mais funcionar como antes, mesmo que preserve antigas formas e não anule antigas funções. É essa a dinâmica da produção do espaço urbano no contexto da estrutura capitalista. Para Soja (1993), a reestruturação se inicia quando há uma descontinuidade nos processos engendrados provando uma "freada", resultando em mudanças:

A reestruturação, em seu sentido mais amplo, transmite a noção de uma "freada", senão de uma ruptura nas tendências seculares, e de uma mudança em direção a uma ordem e uma configuração significativamente diferentes da vida social, econômica e política. (SOJA, 1993, p. 193).

A escolha do conjunto de palavras que Soja utiliza na sua definição de reestruturação, parece-nos adequada diante do que este processo pode abarcar. Especialmente o uso do termo ruptura, que instiga-nos a um aprofundamento. No Dicionário Houaiss dentre as acepções da palavra ruptura emprega-se a definição "interrupção de continuidade" e esta é mui coerente quando utilizada na definição do conceito de reestruturação. A quebra ou a interrupção do contínuo permite-nos uma análise das contradições dos processos socioespaciais inerentes à produção do espaço. O ponto das rupturas sugere o início de uma nova fase, nova não no sentido da heterogeneização da forma, da função e do conteúdo que a estrutura conserva, mas nova no sentido da superação e também da 
durabilidade das dinâmicas de homogeneização da estrutura.

Diante das muitas adjetivações que temos encontrado em nossa revisão bibliográfica a respeito do conceito de reestruturação percebemos que a complexidade das dinâmicas espaciais inaugurou um léxico conceitual para analisar e compreender o espaço na sua contemporaneidade. Começamos por listar, a partir do breve levantamento bibliográfico, as adjetivações dadas ao conceito de reestruturação e a contribuição desse léxico conceitual para a compreensão das dinâmicas espaciais.

O quadro a seguir (quadro 3) destaca algumas das adjetivações mais comuns que o conceito de reestruturação recebe: urbana, urbanoindustrial, urbana e regional, da cidade, produtiva, do espaço, imobiliária e metropolitana. 
Quadro 3 - Usos e sentidos do conceito de reestruturação na análise espacial

\begin{tabular}{|c|c|c|}
\hline Autor & Título do trabalho consultado & Ano \\
\hline \multicolumn{3}{|c|}{ Reestruturação Urbana } \\
\hline Licia Valladares e Edmond Preteceille (Orgs.) & Reestruturação urbana: tendências e desafios & 1990 \\
\hline Ricardo Mendes Antas Jr. & $\begin{array}{l}\text { Notas sobre o uso do conceito de circuitos espaciais produtivos para estabelecer o nexo entre a reestruturação urbana } \\
\text { e as refuncionalizações do espaço: um estudo sobre os fixos de saúde no estado de São Paulo }\end{array}$ & 2011 \\
\hline Raquel Rolnik e Heitor Frúgoli Jr. & Reestruturação urbana da metrópole paulistana: a zona leste como território de rupturas e permanências & 2001 \\
\hline Neil Smith & Reestruturação, reescalonamento e a questão urbana. & 2013 \\
\hline \multicolumn{3}{|c|}{ Reestruturação Urbano-Industrial } \\
\hline Sandra Lencioni & $\begin{array}{l}\text { Reestruturação urbano-industrial: centralização do capital e desconcentração da metrópole de São Paulo - a indústria } \\
\text { têxtil }\end{array}$ & 1991 \\
\hline \multicolumn{3}{|c|}{ Reestruturação Urbana e Regional } \\
\hline Edward Soja & A geografia histórica da reestruturação urbana e regional & 1993 \\
\hline \multicolumn{3}{|c|}{ Reestruturação da Cidade } \\
\hline \multirow{2}{*}{ Maria Encarnação Sposito } & Metropolização do espaço: cidades médias, lógicas econômicas e consumo & 2015 \\
\hline & A produção do espaço urbano: escalas, diferenças e desigualdades socioespaciais & 2011 \\
\hline \multicolumn{3}{|c|}{ Reestruturação Produtiva } \\
\hline Geraldo Augusto Pinto & A reestruturação produtiva & 2013 \\
\hline Floriano de Oliveira & Reestruturação produtiva: território e poder no Rio de Janeiro & 2008 \\
\hline Ricardo Antunes & As respostas do capital a crise estrutural: a reestruturação produtiva e suas repercussões no processo de trabalho & 2000 \\
\hline \multicolumn{3}{|c|}{ Reestruturação do Espaço/Espacial } \\
\hline Mark Gottdiener & A produção social do espaço urbano & 1993 \\
\hline Ruy Moreira & Os quatro modelos de espaço-tempo e a reestruturação espacial brasileira & 2002 \\
\hline \multicolumn{3}{|c|}{ Reestruturação Imobiliária } \\
\hline \multirow{2}{*}{ Paulo César Xavier Pereira } & Reestruturação imobiliária em São Paulo: especificidades e tendências & 2006 \\
\hline & Agentes imobiliários e reestruturação: interesses e conflitos na construção da cidade contemporânea & 2011 \\
\hline Sandra Lencioni & Reestruturação imobiliária: uma análise dos processos de concentração e centralização do capital no setor imobiliário & 2014 \\
\hline \multicolumn{3}{|c|}{ Reestruturação Metropolitana } \\
\hline Saint-Clair Trindade Jr. & A cidade dispersa: os novos espaços de assentamentos em Belém e a reestruturação metropolitana. & 1998 \\
\hline Paulo César Xavier Pereira e Rodrigo Hidalgo & Producción inmobiliaria y reestructuración metropolitana em América Latina & 2008 \\
\hline
\end{tabular}

Elaboração: Juliana Luquez 
A inspiração para essa seção, no âmbito do uso e sentidos sobre o conceito reestruturação, veio como consequência da leitura do livro "Usos e Sentidos do Termo Estrutura", organizado por Roger Bastide, em 1971. Esse livro reuniu diversos pesquisadores, com perspectivas e abordagem teórico-metodológicas diferentes, para debater o conceito de estrutura nas ciências humanas e sociais. O texto de Lencioni (1998), intitulado "Reestruturação: uma noção fundamental para 0 estudo das transformações e dinâmicas metropolitanas" também nos proporcionou uma reflexão ampla da importância do conceito de reestruturação para a compreensão das dinâmicas socioespaciais, atentando-nos para os momentos e o movimento da realização da história produzida a partir de contradições, tensões e descompassos.

Diante da variedade de usos do conceito de reestruturação e das diversas adjetivações conferidas a este, aproximamo-nos da advertência feita por Lencioni, no texto acima mencionado, sobre a importância de se voltar a tríade analítica forma-função-estrutura. Aqui começamos a nos deparar com possibilidades importantes, no nível do método, para compreender as várias adjetivações conferidas ao conceito de reestruturação e seus sentidos na compreensão do espaço.

2.2.2. Reestruturação: adjetivações, sentidos e perspectivas metodológicas

Nesta seção apresentamos quatro artigos do levantamento bibliográfico realizado a partir dos quais chegamos a uma questão de método: o uso do conceito de reestruturação, as respectivas adjetivações empregadas ao conceito e os sentidos dados aos termos nos despertaram para as perspectivas metodológicas utilizadas para pensar a realidade e suas abstrações. Em outras palavras, a construção ou eleição de um conceito e das suas variações adjetivas não são escolhas simples ou isentas de caráter metodológico, justamente por ser um exercício do pensamento sobre o real e porque o conceito não pode conter toda a 
riqueza do real; mas pode refletir aspectos essenciais de fenômenos ou processos analisados (LENCIONI, 2008).

Sabemos, pois, que o exercício de pensar o real e capturar conceitualmente o que lhe é essencial combina elementos teóricos e perspectivas metodológicas. Nos textos de Rolnik e Frúgolli (2001), Brenner (2013), Sposito (2013) e Pereira (2005) buscamos identificar qual a contribuição no uso do termo reestruturação e a partir da adjetivação conferida considerar os aspectos metodológicos contidos no pensamento dos autores para a combinação entre o conceito e sua adjetivação ideal na tentativa de explicar a realidade sob as lentes do método com as quais se investiga.

No texto Reestruturação urbana da metrópole paulistana: a Zona Leste como território de rupturas e permanências, Rolnik e Frúgolli (2001) utilizam o conceito de reestruturação urbana com o entendimento de que este refere-se à dinâmica territorial do modelo centro/periferia, considerando a instalação de shopping centers como elemento dinamizador da lógica espacial, "viabilizando novas formas de organização da produção imobiliária residencial" (p. 46).

Deve-se ressaltar, entretanto, que a multiplicação de shopping centers em si não está necessariamente ligada à reestruturação urbana. Mas dentro do desafio de pensar a articulação desses estabelecimentos com esse processo - ligado a fenômenos como a desindustrialização, o novo papel do setor de serviços e de intervenção urbana do grande capital, os novos padrões de localização da moradia, entre outros - , não significa assumi-los apenas como espaços constitutivos de enclaves excludentes, mas também como espaços que vêm incorporando de forma massificada as classes médias e sobretudo as populares (tanto na estrutura de consumo como na de lazer e entretenimento), incluindo sua inserção nos territórios das periferias consolidadas. (ROLNIK; FRÚGOLLI, 2001, p. 55). 
Os autores consideraram em sua análise a lógica dualista do modelo centro/periferia, concluindo para a metrópole paulistana o que é típico de muitas (ou quase todas) as aglomerações urbanas dos espaços periféricos do capitalismo (as cidades latino-americanas, asiáticas e africanas): cidades superpopulosas, segregadas social e espacialmente, com largas periferias empobrecidas e em constante expansão, baixa infraestrutura de serviços públicos ou de acesso a atividades especializadas e ao consumo etc.

Rolnik e Frúgolli consideraram que o modelo centro/periferia "continua marcando, de certa forma, as principais tendências de organização territorial metropolitana, ainda que diversos fenômenos possam estar gradativamente a relativizá-lo, como a diminuição perversa da segregação social" (p. 56). A diminuição perversa da segregação social a qual os autores se referem parece estar ligada à produção doméstica extensiva das residências na metrópole, a produção imobiliária intensiva e a contínua formação de favelas e cortiços no centro e na periferia, espacialmente mesclados dando ritmo a dinâmica de reestruturação urbana considerada, na perspectiva interpretativa do modelo centro/periferia, como uma das tendências da organização territorial metropolitana.

Neil Brenner explora em seu texto, intitulado Reestruturação, reescalonamento e a questão urbana, os limites e as possibilidades escalares dos padrões de reestruturação urbana e regional. A perspectiva proposta pelo autor é apresentada a partir do que ele chama de problemática da reestruturação (BRENNER, 2013). Brenner evoca questões à essa problemática considerando a importância de "decifrar as paisagens ininterruptamente cambiantes do capitalismo" (BRENNER, 2013. p. 200). O sentido do conceito de reestruturação utilizado pelo autor parece se aproximar da noção de rupturas e transformações do capitalismo na fase contemporânea de sua reprodução. O caminho encontrado por Brenner para essa análise vai ao encontro de "dimensão 
escalar dos processos de reestruturação sob o capitalismo histórico e contemporâneo" (p. 201), ao que ele chama de reescalonamento.

Brenner deixa manifesto que 0 uso e o sentido do termo reestruturação expressa-se por vias de método: "as considerações escalares agora figuram explicitamente nas explicações mais espacialmente sensíveis e metodologicamente reflexivas da reestruturação capitalista contemporânea" (BRENNER, 2013, p. 201). O autor destaca também que a compreensão da produção do espaço e dos processos inerentes à essa produção requer um olhar interessado no aspecto escalar, sendo este também um produto com inúmeras possibilidades de transformação histórica.

A questão urbana à qual Brenner se refere vai além de especificidades funcionais da cidade e do urbano, analisados muitas vezes como "sítios geográficos". O autor considera a especificidade escalar, sendo esta "uma materialização geográfica multifacetada das relações sociais capitalistas" (BRENNER, 2013, p. 204).

Em suma, Brenner lança mão do conceito de reestruturação considerando a dimensão multiescalar do processo e os arranjos espaciais (e também institucionais) interescalares relação através da qual seria possível, adotando o caminho metodológico da análise escalar dos processos socioespaciais, compreender a produção do espaço e a natureza dos processos inerentes à questão urbana. Brenner, nos sugere que a adjetivação do conceito de reestruturação é uma questão multiescalar sob a lógica de produção capitalista (do espaço, de relações e de coisas), e esta é uma questão de método de análise: "estabelecer uma concepção de escala [...] profícua para decifrar os padrões de reestruturação urbana e regional" (BRENNER, 2013, p. 209).

A perspectiva de Brenner parece vir de encontro com a perspectiva de Sposito (2013), nos referimos estritamente ao texto Metropolização do espaço: cidades médias, lógicas econômicas e consumo, o qual 
discorreremos em paralelo com Neil Brenner. A começar pelo fato de que parece-nos que Sposito privilegia a especificidade funcional na escala da cidade e não a especificidade escalar dos arranjos espaciais do urbano e da cidade, essa última considerada por Brenner como parte da dinâmica de produção do espaço.

Sposito adota a noção de sistema urbano para introduzir o debate sobre a formação das redes urbanas brasileiras "cuja a gênese estava associada a diferentes economias regionais" e que a consolidação desse sistema urbano se dá concomitante a industrialização completa no Brasil (SPOSITO, 2013, p. 131). Sposito, após um breve panorama da constituição do sistema urbano brasileiro e as redes urbanas a ele associados, apresenta dois elementos para se compreender a restruturação urbana no Brasil: as novas relações na escala internacional e o papel do consumo. O primeiro está relacionado ao conceito de reestruturação e sua adjetivação "produtiva", ou seja, refere-se à transição do regime de acumulação fordista para o regime de acumulação flexível. Para Sposito esse elemento trouxe alterações que "interferiram diretamente da divisão interurbana do trabalho [...] o que teve rebatimentos importantes na economia, na sociedade e no espaço" (SPOSITO, 2013, p. 133). A autora ainda acrescenta que:

Esse movimento propiciou desconcentração territorial da atividade produtiva e, em alguma escala, perda relativa dos papéis produtivos das metrópoles, tendo como par combinado a concentração econômica e a centralização espacial. (SPOSITO, 2013, p. 134).

O segundo elemento ao qual a autora dá destaque é "a redefinição dos papeis urbanos orientados pela mudança no perfil do consumo no Brasil atual, com destaque mais direto às cidades médias" (p. 135). Esse segundo elemento tem, para a autora, três características específicas: 1 ) o desenvolvimento e a expansão das novas tecnologias de informação (TCIs), transformando a "competitividade espacial como um elemento novo da urbanização", redefinindo as escalas geográficas da rede urbana; 
2) em função da diversificação e da complexificação da produção agropecuária, no contexto do agronegócio, as desvantagens para as cidades pequenas e a ampliação da importância e dinâmica das cidades médias e grandes; 3) o desenvolvimento do ensino superior e da pesquisa com a criação e ampliação de Universidades e Centros de Pesquisa em cidades pequenas e médias.

[...] posso afirmar que estas dinâmicas reforçam a tendência de ampliação da dispersão urbana, na escala das cidades, da urbanização difusa, na escala de algumas centenas de quilômetros, tanto quanto processos de aglomeração espacial. De outro lado, todas estas dinâmicas têm rebatimentos na escala regional e nacional, promovendo a passagem de estruturas espaciais mais complexas, muitas vezes policêntricas, que não anulam as anteriores, mas a elas se articulam, gerando interações espaciais de vários tipos, intensidades e direções. (SPOSITO, 2013; p. 138).

A escala de Sposito, parece-nos, considerando esse texto, ser estritamente geográfica e circunscrita cartograficamente: o local, o regional, o metropolitano, a cidade pequena, média e a metrópole. E não processual e socialmente produzida como sugere Brenner com as noções de escalonamento e reescalonamento associadas ao conceito de reestruturação como potencial interpretativo das complexidades contemporâneas de transformação sob o capitalismo moderno.

Portanto, a autora sugere um par adjetivo ao conceito de reestruturação: reestruturação urbana e da cidade. Sposito justifica "esta duplicação conceitual [...] como um caminho de método" (SPOSITO, 2013, p. 141). Essa abordagem metodológica, tem para a autora, três perspectivas, a saber:

- "[A] reestruturação urbana tem relação direta com urbanização e precisa ser compreendida a partir do conjunto de cidades e das relações entre elas, sem o que não se evidencia a redefinição da divisão interurbana do trabalho. A reestruturação da cidade é apreendida mais pelas relações entre as partes da cidade, e pode ser aplicada esta noção toda vez que ocorrem transformações 
profundas na lógica que orienta a organização dos usos de solo e as articulações entre eles". (p. 141);

- "[O] reconhecimento da reestruturação urbana como articulação entre escalas geográficas, do regional ao internacional, enquanto, de outro lado, a reestruturação das cidades é afeita, não exclusivamente, mas prevalentemente, às lógicas locacionais atinentes à escala local [...]". (p. 141);

- "Considero que a reestruturação urbana revela e é orientada muito mais por processos econômicos e políticos e, na reestruturação das cidades, a dimensão espacial se sobressai com todos os ingredientes afeitos à vida social. A relação entre processos e formas é indissociável neste par, embora considere que, no plano da reestruturação urbana, se revelam os processos como evidência. No que concerne à reestruturação da cidade, os processos de mudança que justificam o reconhecimento de uma mudança profunda, que o termo reestruturação exige, podem se expressar de modo mais claro em formas espaciais". (p. 142).

Sposito considera a cidade e suas especificidades funcionais intraurbanas e não a relação dos processos socioespaciais e a constituição de arranjos territoriais indissociáveis da noção de escala em uma perspectiva de totalidade analítica do real. A ruptura analítica parece comprometer a noção de totalidade dos processos socioespaciais; contudo se justifica pela escolha metodológica que constrói uma maneira de se pensar o real.

O quarto e último texto selecionado para esta exposição, tem como título Reestruturação Imobiliária em São Paulo: especificidades e tendências, escrito por Pereira, em 2005. Trata-se de uma contribuição que busca questionar a interpretação do modelo centro/periferia para a compreensão do espaço metropolitano paulistano e "afirmar o entendimento do urbano como totalidade e discutir o chamado padrão 
periférico de crescimento urbano" (p. 2). O sentido do conceito de reestruturação, tomado pelo autor, sugere uma perspectiva de totalidade contraditória e aberta, e a adjetivação proposta, reestruturação imobiliária, articula-se entre a globalização e a metropolização.

Pereira, realça também que esse sentido indica, em suas abordagem teórica e perspectiva metodológica, uma nova estruturação que gera uma nova produção do espaço, momento e movimento de continuidades e descontinuidades. Com relação à adjetivação empregada ao conceito, reestruturação imobiliária, o autor resume como sendo

[...] uma maneira de falar sobre a atual transformação metropolitana onde se articulam o local e global, o espacial e o social, dando conta simultaneamente do que seria o mais específico e o mais abrangente que afeta a produção do espaço e a distribuição territorial dos grupos sociais. [...] A noção de reestruturação imobiliária unifica diferentes dimensões e níveis de análise referindo-se, também, ao local e ao global enquanto processo e não apenas enquanto escala. Trata-se, portanto, de construir uma noção mediadora da urbanização e da industrialização, que devido aos seus entrelaçamentos já foram considerados processos duplos. Mas, além de pretender dar conta dos laços que unificam estes processos na indústria imobiliária, também, atualiza e identifica o conteúdo do momento em que esses processos ainda separados se imbricam com os da globalização e da metropolização. De forma que na noção proposta estão contemplados as dimensões - social e espacial - e os níveis - global e local. (PEREIRA, 2005, p. 4).

A perspectiva de Pereira nos conduziu à uma questão sobre a maneira de adjetivar o conceito de reestruturação, qual seja: busca-se explicitar o caráter predominante ou determinante do processo de reestruturação em curso na realidade a qual se quer revelar? Em outras palavras, considerar o que é predominante, no tempo e no espaço, muitas vezes só nos aproxima das características da dinâmica de um processo socioespacial; mas não da sua gênese e da sua historicidade, par indispensável para penetrar as determinações históricas das relações sociais de produção no contexto da atual fase de reprodução do capitalismo. 
A adjetivação conferida ao conceito de reestruturação, ora, nos pareceu buscar revelar dinâmicas territoriais intra e interurbanas, ora a compreensão das transformações socioespaciais como momentos do movimento da totalidade. Porém, a percepção da perspectiva metodológica de análise e interpretação do real nos retira de uma confusão teórica acerca do uso e do sentido do termo. Na perspectiva metodológica de Pereira:

$\mathrm{Na}$ reestruturação recupera-se o movimento dos processos sociais e, por isso, se evidencia que os fragmentos emergentes fazem parte de uma estruturação do espaço que não poderá ser compreendido isoladamente, mas como partes de uma estrutura nova, que contém predicados e qualidades sociais que não podem ser coisificados e vão além do de seus artefatos isolados na sua relação com a nova totalidade [...]. (PEREIRA, 2006, p. 8)

Ao analisar a apropriação do espaço e a expansão metropolitana de São Paulo, Pereira questiona, como já mencionamos anteriormente, o potencial explicativo do modelo centro/periferia para as transformações contemporâneas da metrópole e de sua região e lança mão de uma via metodológica que extrapola as questões geométricas ou de tamanho das cidades e de sua população. Uma via que introduz ao tema as diferentes formas de produção do espaço.

Pereira alerta-nos que o sentido do uso do termo reestruturação imobiliária "encontra especificidade num particular movimento de valorização do capital e da propriedade imobiliária, que tende a funcionar e a existir como capital", o autor considera essa a novidade essencial da reestruturação (PEREIRA, 2006, p. 11).

Finalmente, Pereira incide-nos em uma última questão: a relação das reestruturações capitalistas com as formas de produção do espaço. $\mathrm{Na}$ atual fase de desenvolvimento de nossa pesquisa temos visto sentido, inspirados na perspectiva metodológica de Pereira, compreender o processo de reestruturação do espaço como álibi ${ }^{62}$ do capital na produção

${ }^{62}$ Essa perspectiva se funda em Brenner, que afirma: "A forma 'urbano' sob o capitalismo 
(e reprodução) do espaço no contexto metropolitano.

Encerramos nosso diálogo teórico, conduzido pelos autores aqui apresentados (Rolnik e Frúgolli; Brenner, Sposito e Pereira), certos de que não se resumem a estes as abordagens do tema tratado, mas que a partir de suas perspectivas metodológicas podemos verificar a abrangência dos usos e sentidos do conceito de restruturação e das adjetivações a ele conferidas.

A cidade é uma obra civilizatória da humanidade, não foi 0 capitalismo que a criou. Ele a tomou. E como modo de produção, ele a produz e se reproduz nela. Fazendo sobressair suas contradições, sem que as possamos superar. A discussão aqui realizada considerou, especialmente, o caráter dinâmico da produção e reprodução do capitalismo na "problemática do espaço".

Nossa reflexão sobre os usos, sentidos e adjetivações do conceito de reestruturação não está restrita ao campo metodológico, como privilegiamos debater nessa seção, mas busca compreender o processo de reestruturação do espaço, suas rupturas e continuidades relacionando-o ao movimento e aos momentos da produção do espaço metropolitano. Dessa maneira, e conforme destacamos anteriormente, a eleição das categorias forma-função-estrutura, como instrumento metodológico para a periodização e análise das fases do processo de reestruturação do espaço, permitiu-nos identificar os elementos do fenômeno social total que se manifestam em continuidades e descontinuidades nas relações sociais e, concomitantemente, descrever o movimento contraditório de realização da sociedade urbana compreendendo sua conformação e refletindo sobre suas tendências. Dentro desse quadro, realizamos a análise das fases do processo de reestruturação do espaço em São Gonçalo, à qual é dedicado a próxima seção.

é um efeito ideológico de práticas específicas nos planos históricos e geográficos, que criam um aspecto estrutural de singularidade, coerência e delimitação territorial [...]". (BRENNER, 2014, p.20). 


\subsection{As fases do processo de reestruturação do espaço em São Gonçalo}

A periodização que anteriormente apresentamos, destacando os momentos e as rupturas do processo de urbanização, nos servem de ponto de partida para a identificação das fases da reestruturação do espaço. Isso porque

Mas, precisamente, o tempo se conhece e se realiza no
espaço, socialmente por uma prática espacial. O espaço, do
mesmo modo, se conhece num tempo e por um tempo.
(LEFEBVRE, 2000, p. 252 $)^{63}$

Aqui damos lugar a análise do espaço-tempo de cada reestruturação do espaço em São Gonçalo. Se nas páginas anteriores, optamos por problematizar o tema considerando as implicações atuais da conformação metropolitana à qual São Gonçalo está inserida, nessa seção optamos por uma exposição regressivo-progressiva, um caminho percorrido pelas rupturas que solapam os equilíbrios momentâneos e nos possibilitam compreender a gênese das continuidades na realização da sociedade urbana fluminense.

Para tanto, insistimos que a dinâmica da produção do espaço urbano de São Gonçalo, inserida na conformação do espaço metropolitano fluminense, pode ser compreendida a partir de fases da reestruturação do espaço, suas rupturas e continuidades. Nossa análise propõe dois momentos determinantes na dinâmica, o urbano-industrial e o metropolitano-financeiro, e considera três fases críticas do processo de reestruturação: a primeira fase (1920-1960), refere-se a urbanização que precede a industrialização e é capturada por ela; a segunda fase (19701990), aprofunda e matura a urbanização espoliadora; e a terceira fase (anos 2000-presente), marca a transição à urbanização especulativa (ou financeira) que impõe à problemática urbana análises e interpretações

63 Texto original: Mas, précisément, le temps et connaît et se réalise dans l'espace, socialement par une pratique spatiale. L'espace, de même, se connaît dans un temps et par un temps. (LEFEBVRE, 2000, p. 252). 
para além do dualismo centro-periferia no contexto da atual conformação da metrópole e de sua região.

\subsubsection{O processo de estruturação do espaço em São Gonçalo}

A intenção dessa abordagem é refletir sobre a configuração espacial de uma cidade e atentar-se aos seus períodos de rupturas, transformações e reprodução sob continuidades por vezes encobertas, ou seja, reconhecer a reestruturação capitalista do espaço urbano. As formas de estruturação e reestruturação do espaço urbano gonçalense serão, aqui, decompostas e recompostas. Assim, partimos da premissa que a evolução urbana de São Gonçalo introduz-se no processo de consolidação da expansão urbana da metrópole fluminense e relaciona-se com os processos e contradições socioespaciais engendrados na produçãoreprodução da metrópole.

A composição visível da paisagem urbana contribui para revelar as características da estrutura, forma e funções urbanas que ali estão operantes, mas são os conteúdos das relações sociais de produção que auxiliam na decodificação dessa realização do tempo no espaço e viceversa. Para Soja (1993), a cidade capitalista não pode esconder-se de seu modo de produção. E também por isso, não pode abster-se das mudanças inerentes à dinâmica do capitalismo que expande-se ao espaço préexistente engendrando subsequentes períodos de reestruturação.

Pensar a cidade capitalista, seu movimento de estruturaçãoreestruturação, é estar sensível aos eventos que indicam, por exemplo, os diferentes regimes de acumulação que, no entendimento de Harvey (2011), podem ser mediados no modo de regulamentação social e política associada à cada período de transição. As mudanças não são exclusividades do setor econômico e de seus períodos de crise, são também e dialeticamente, características do espaço e da sociedade. Para Harvey 
São abundantes os sinais e marcas de modificações radicais em processos de trabalho, hábitos de consumo, configurações geográficas e geopolíticas, poderes e práticas do Estado. No Ocidente, ainda vivemos uma sociedade em que a produção em função de lucros permanece como o princípio organizador básico da vida econômica. Portanto, precisamos de alguma maneira representar todos os grandes eventos ocorridos desde a primeira grande recessão do pósguerra, em 1973, maneira que não perca de vista o fato de as regras básicas do modo capitalista de produção continuarem a operar como forças plasmadoras invariantes do desenvolvimento histórico-geográfico. (HARVEY, 2011; p. 117).

Entendemos que a forma mais complexa para a compreensão dessas modificações é a cidade - ou o que essa se tornou no atual contexto de metropolização do espaço. Nela subsistem estruturas e funções sujeitas às alterações espaço-temporais e para identifica-las buscamos uma análise do espaço urbano de São Gonçalo a partir das transformações urbanas verificadas e as anunciadas como maturadas e tendenciais.

Soja nos parece ser a referência mais coerente aos propósitos dessa análise quando debruça-se sobre a investigação da geografia histórica da reestruturação urbana e regional de Los Angeles.

Usou-se uma concatenação de paradoxos para descrever Los
Angeles e exemplificar a reestruturação contemporânea da
cidade capitalista, sua desconstrução e sua reconstituição
provisória. [...]. O cenário avistado é o de uma nova
geografia da modernização, uma paisagem urbana pós-
fordista emergente, repleta de sistemas mais flexíveis de
produção, consumo, exploração, espacialização e controle
social do que os que marcaram até o presente a geografia
histórica do capitalismo. (SOJA, 1993; p. 266).

Soja (1993) ao descrever Los Angeles e seus processos espaciais ao longo do tempo sugere que "Los Angeles é o lugar onde tudo se encontra", pois sua ilustração e sintetização da dinâmica da espacialização capitalista na cidade: do ouro verde (agricultura) e do ouro negro (petróleo), daquela Los Angeles tomada pela indústria a partir da década de 1930 e que, década após década, passou a experimentar um 
significativo crescimento populacional e produtivo no contexto da economia capitalista estadunidense até a possibilidade de outros espaços, ou outras formas de produzir o espaço sob novas lógicas pós-fordistas - a exópolis, por exemplo, forma urbana contemporânea.

Não queremos estabelecer características pretensiosas entre Los Angeles e São Gonçalo, isso não nos parece coerente. Mas, é inevitável, a partir de Soja, desconsiderar a necessidade de uma análise mais minuciosa dos processos espaciais que conduziram a estruturação e as reestruturações do espaço em São Gonçalo. Se, para Soja, tudo se junta em Los Angeles, para nós, é preciso juntar os momentos da produção e da reprodução capitalistas do espaço no movimento da urbanização de São Gonçalo a partir das lógicas que conduziram às transformações socioespaciais antes, durante e depois da consolidação da industrialização.

Consideramos importante uma advertência de caráter expositivo: primeiramente evidenciaremos um quadro da estrutura urbana de São Gonçalo no final dos anos 1920 aos anos 1930, que nos servirá de substrato à problematização dos períodos de reestruturação do espaço da cidade; em seguida se passaremos a caracterização de cada fase da periodização proposta consideradas na realidade complexa da urbanização fluminense.

Iniciamos, assim, uma análise regressivo-progressiva"64 em busca da compreensão da estrutura urbana de São Gonçalo até a década de 1930 a fim de explicitar a natureza das transformações que conduziram o espaço aos seus períodos de reestruturação ao longo do tempo até o presente. Começamos por nos indagar: Qual seria a estruturação do espaço de São Gonçalo no início do século XX? Quais os atores hegemônicos na determinação das relações sociais de produção? Onde segregavam-se os ricos? E quais os lugares predominantemente ocupados pela classe operária e pelos pobres? Quais as características das áreas

64 Sobre as potencialidades do método regressivo-progressiva ver LEFEBVRE (1970); MARTINS (1996) e FREHSE (2001). 
suburbanas e periféricas de São Gonçalo em relação aos demais subúrbios metropolitanos do Rio de Janeiro? O padrão centro-periferia basta para aplicar a expansão urbana da aglomeração metropolitana fluminense, da qual São Gonçalo se erige como a segunda maior concentração populacional?

Todas essas questões, quiçá, encontrem fundamentos na singularidade da estrutura urbana de São Gonçalo composta pela formação de três centralidades intra-urbanas e que podem ser consideradas como principal indício da natureza das relações sociais de produção contidas no espaço gonçalense, tanto em termos de rupturas, como em termos de continuidades. Referimo-nos ao núcleo central da cidade e as centralidades de Neves e de Alcântara. Expliquemos.

A citricultura foi para São Gonçalo, assim como para outras localidades suburbanas do Rio de Janeiro65, um importante elemento dinamizador e catalisador de urbanização. Essa atividade agrícola utilizava-se de meios urbanos para sua manutenção, como os portos e as ferrovias para o transporte de suas cargas, como também os bondes e o trem para o deslocamento de trabalhadores empregados diretamente na citricultura ou naquelas derivadas desta. A citricultura nunca se apresentou isolada no campo, ao contrário, sua rede conectava campo e cidade, favorecendo ao rápido processo de transição do rural para o urbano. Especialmente pelo caráter que esta atividade exerceu em seus interesses de exportação, por exemplo, com a instalação de postos de beneficiamento e estocagem nas áreas urbanas; e, posteriormente, com o declínio desta atividade no início dos anos 1940, com a conversão destes terrenos em imediatas áreas urbanas, uma vez que o rural já se encontrava diluído no urbano.

65 Nova Iguaçu (que antes das emancipações compreendia os territórios de Duque de Caxias, Nilópolis, Belford Roxo, Queimados, Japeri e Mesquita) e Itaboraí. Sobre o desenvolvimento urbano e a atividade agrícola de Nova Iguaçu encontramos em SOARES (1962) a discussão mais completa. Em relação a São Gonçalo, além dos textos de GEIGER (1954; 1956) e MENDES (1950), também sugerimos nosso trabalho como ponto de partida à discussão (VIANA, 2013). 
Contudo, a citricultura não foi o único ou o mais importante facilitador de urbanização em São Gonçalo, a diversidade econômica da municipalidade, descentralizou as funções e complexificou a estrutura urbana da cidade, fazendo com que tanto a indústria de diferentes ramos no seu modelo mais tradicional de fábrica, a construção de suas vilas e bairros operários, quanto as etapas de produção, distribuição e consumo dos produtos agrícolas pudessem dirigir a conformação interna e na relação de São Gonçalo com seu em torno.

Na passagem dos anos 1930 para os anos 1940, a cidade inicia sua transição urbana por meio da determinação econômica industrial. A área urbana se estendia e se espraia desde a conurbação com Niterói, (Neves) conectando-se diretamente com a área central de São Gonçalo, seguindo até a principal localidade às portas da zona produtiva rural (Alcântara). Esta estrutura resultou na consolidação de três importantes centros urbanos e no desenvolvimento concomitante de duas prósperas atividades econômicas: a indústria, acompanhada de seus apitos, seus movimentos característicos, seus uniformes e sua lógica de produção e reprodução do cotidiano; e, as lavouras cítricas, retalhadas pela lógica capitalista de reprodução de lucros, tanto da terra, quanto do fruto, de seus postos de beneficiamentos junto às áreas urbanizadas, aproveitando-se das vantagens de mão de obra e transportes urbanos.

Soares nos desperta a uma importante percepção sobre a duração da atividade citricultora em relação ao crescimento urbano-industrial nos subúrbios produtores. Para a autora a riqueza representada pela laranja justificava ou compensa os investimentos nas lavouras (SOARES, 1962). Todavia, as relações sociais de produção haveriam de solapar estrutura urbana de São Gonçalo reestruturando o espaço produtivo promovendo rupturas e expandido continuidades, especialmente na disputa de interesses políticos e econômicos das classes dominantes locais e aquelas atuantes da escala regional, considerando a influência das cidades do Rio 
de Janeiro e Niterói, no que se refere à captação de investimentos públicos, como obras em ruas e estradas, serviços de transporte.

Soares e Bernardes (1995) dedicaram parte significativa de seus estudos a contribuir para o entendimento do "Rio de Janeiro cidade e região" do Rio de Janeiro, essa conformação regional que aglutinou a cidade do Rio de Janeiro e seu em torno por meio do movimento de produção e reprodução da metrópole. As autoras buscaram explicar como se deu a integração das áreas suburbanas à área urbana da metrópole carioca. Uma das maiores contribuições foi atentarem-se para a integração dos subúrbios periféricos a essa dinâmica, ou seja, aqueles espaços que estavam para além dos limites administrativos da cidade do Rio de Janeiro, para onde extravasava a urbanização e configurava a espacialidade metropolitana.

Soares e Bernardes, descreveram a incorporação dos subúrbios agrícolas e industriais à dinâmica metropolitana do Rio de Janeiro. Embora, a análise empírica tenha se concentrado na integração dos subúrbios metropolitanos da porção ocidental da Guanabara, essa mesma análise serviu-nos de referência para trilhar os meandros da estruturação do espaço metropolitano do Rio de Janeiro66. Foi a partir dessa contribuição que percebemos a importância de aprimorarmos o olhar para o processo de implosão-explosão da metrópole carioca para um limite não continuo de sua área de influência que área, o lado oriental da Baía de Guanabara e destacar São Gonçalo como potencialidade à compreensão da produção do espaço da aglomeração metropolitana em toda a sua complexidade. Dessa forma, a referência a esse quadro tem como intuito pensar as implicações das transformações socioespaciais para a constituição das fases do processo de reestruturação em São Gonçalo e contribuir para a sistematização dos estudos urbanos fluminenses.

${ }^{66}$ Outra análise que nos serviu de referência, considerando o contexto da urbanização paulistana, foi o trabalho clássico de LANGENBUCH (1968). 
O quadro: São Gonçalo possuía uma estrutura urbana complexa, diferentes funções (industrial e citricultora, ambas conduzidas e influenciadoras do processo de urbanização), formas herdadas do período agroexportador que passaram a ser subordinadas - embora não superadas - pelas formas da urbanização moderna.

2.3.2. A urbanização de São Gonçalo no movimento da reestruturação do espaço

A primeira fase de reestruturação do espaço em São Gonçalo pode ser identificada no contexto da prosperidade econômica favorecida pelo sucesso das atividades agrícola e industrial que corroborou para a transição da determinação rural à urbana. Posteriormente, com a desvalorização da terra agrícola e a consequente transformação destas em terras urbanas, tendo em vista o período a partir dos anos 1940, no qual as antigas fazendas, chácaras policultoras e os inúmeros laranjais, tornaram-se áreas interessantes para loteamentos impulsionados pelo desenvolvimento do espaço urbano metropolitano que combinava a necessidade de produção de moradias nos subúrbios imediatos e intermediários do Rio de Janeiro e de espaços produtivos para a consolidação da industrialização fluminense.

É neste contexto, a partir dos anos 1940, que verificamos uma ruptura no processo de produção da cidade e que se intensifica ao longo dos anos 1950 e se concretiza nos anos 1960. A reprodução de continuidades no processo de produção do espaço contraditório do capitalismo permite que as relações sociais de produção conduzam as transformações em ritmos variados, não sendo necessariamente mudanças abruptas ou isoladas de outras formas de realização. Se a atividade industrial alavancou uma forma de urbanização, a atividade agrícola havia contribuído para a construção de um espaço urbano sob relações de trabalho e de propriedade não urbanas. A figura do 
atravessador, é um exemplo dessa última afirmação. Ao atravessador cabia a função de mediar o trabalho na produção de laranja, limão, abacaxi, tangerina entre o fazendeiro e os trabalhadores e a compra do produto entre o fazendeiro e o mercado. A função do atravessador continha a complexidade das relações sociais de produção que produziam uma forma de urbanização e uma cidade que seria tomada pela industrialização que subordinaria o movimento da urbanização já em curso.

Se havia uma tendência à industrialização em São Gonçalo, contudo, essa tendência não anulou, de imediato, o prestígio econômico da agricultura nem a sua base produtiva. O que ocorreu nesse período foi que o mesmo espaço estava sendo produzido, ao mesmo tempo, por diferentes atividades (agrícola, industrial, portuária). Se a localidade de Neves, devido a conurbação com o bairro operário do Barreto, em Niterói, estruturava-se em torno da industrialização, outros espaços estruturavam-se em torno das atividades agrícolas complexas, destinadas à exportação, dinamizadoras do comércio regional e catalisadoras de privilégios de infraestrutura urbana, como sugere Machado (2002) ao relatar a organização dos transportes coletivos e a eletrificação das linhas de bonde no município de São Gonçalo. O acordo da empresa responsável pela operação do serviço de transporte de bondes - Companhia Cantareira -, inicialmente, compromete-se com a eletrificação da "linha do trecho que ia de Neves à Vila de São Gonçalo [Centro do Município], e, posteriormente, do trecho que seguia da Vila de São Gonçalo ao Alcântara..." (Machado, 2002; p. 18). Contudo, em 1932, a empresa sugere à Prefeitura que esse acordo seja invertido. Isso nos leva a crer que essa decisão está intimamente ligada à necessidade de investimento nas áreas agrícolas, especialmente no serviço de transporte, necessário à mobilidade dos trabalhadores envolvidos nesta atividade e ao processo de valorização do espaço orquestrado pelos proprietários fundiários e dos meios de produção junto ao poder público. 
O ano de 1923 é marcado pela solicitação da Cantareira em inverter as bases do acordo com a Prefeitura, pretendendo realizar a eletrificação do trecho da Vila de São Gonçalo ao Alcântara para posteriormente realizar o mesmo em Neves. A tentativa de inversão das obras, por parte da Cantareira, causa grande insatisfação para com os negociantes e proprietários de Neves, que chegam a endereçar, em maio de 1923, um memorial ao prefeito para que fosse mantido o primeiro contrato. Em outubro deste mesmo ano, o então prefeito de São Gonçalo, Dr. Olavo Lamego, envia um ofício [...] ao Secretário Geral do Estado afirmando que a inversão do contrato de eletrificação da linha de bondes no município era contrária aos interesses municipais, pois tal melhoramento visava, principalmente, atender à exportação da pequena lavoura gonçalense, que, segundo o ofício, se escoava toda ela pelos sete portos localizados no trecho das Neves a São Gonçalo. Desta forma, o prefeito solicitava o indeferimento do pedido da Cantareira, pois este acarretaria sérios e graves prejuízos à produção e exportação desta localidade.

Por outro lado, porém, os moradores de Alcântara, também, se organizavam para lutar pela inversão das obras de eletrificação. Proprietários, industriais e negociantes desta localidade elaboram, em agosto de 1923, um abaixoassinado a ser entregue ao Interventor Federal, Dr. Feliciano Sodré, defendendo a eletrificação do trecho Vila de São Gonçalo-Alcântara, antes mesmo de Neves. A petição alegava que o transporte de bonde a vapor causava prejuízos consideráveis à lavoura local.

A pressão exercida pelos proprietários de Neves, com apoio do Prefeito e da imprensa escrita, não surtiu o esperado efeito. Neste mesmo ano, segundo a Mensagem do Presidente de Estado à Assembleia Legislativa do Rio de Janeiro, de 1924, foi permitido a inversão dos trabalhos de eletrificação nas linhas de bonde do município. (MACHADO, 2002; p. 21).

A descrição de Machado (2002) evidencia o fato de que a atividade citricultora em São Gonçalo é elemento essencial para a compreensão do processo de urbanização. Mesmo que as obras clássicas e os registros da impressa local tenham indicado a importância da citricultura em São Gonçalo, esta foi poucas vezes considerada como urbanizadora. A dificuldade em articular a importância da citricultura ao processo de urbanização em São Gonçalo, a ponto de não o perceber na simultaneidade com a instalação de indústrias, fazem com que as continuidades presentes em todo o processo de urbanização sejam 
encobertam ou manifestas apenas na sua relação com a consolidação da cidade industrial da segunda metade do século XX: a periferização como fronteira de expansão do capital, a espoliação como forma de reprodução social e a segregação que não se sustenta a não ser que seja reforçada pelas relações sociais - eis o aprofundamento do processo triádico de fragmentação-hierarquização-homogeneização.

Assumimos que a produção do espaço urbano gonçalense não se deu apenas por meio da atividade industrial exercida, inicialmente, na localidade de Neves, mas também pelo desenvolvimento econômico alcançado pela citricultura que, promoveu a urbanização de áreas além da conurbação Barreto-Neves, abrindo terreno à instalação de indústrias de diferentes ramos e inclusive a entrada de capital estrangeiro no processo de industrialização fluminense, consolidando o eixo Neves-CentroAlcântara na expansão urbana radial do território gonçalense

Posteriormente, com início do parcelamento de terras agrícolas, surgem novos bairros urbanos na então zona rural do município (imagem 18). Essas transformações anunciavam a transição da determinação urbana sobre a rural e a industrial sobre a agrícola, tão somente porque esse movimento estava articulado com a expansão da Metrópole Rio e do processo de regionalização metropolitana. 
Imagem 18 - Bairro Laranjal: antiga área de citricultura (década 1950)

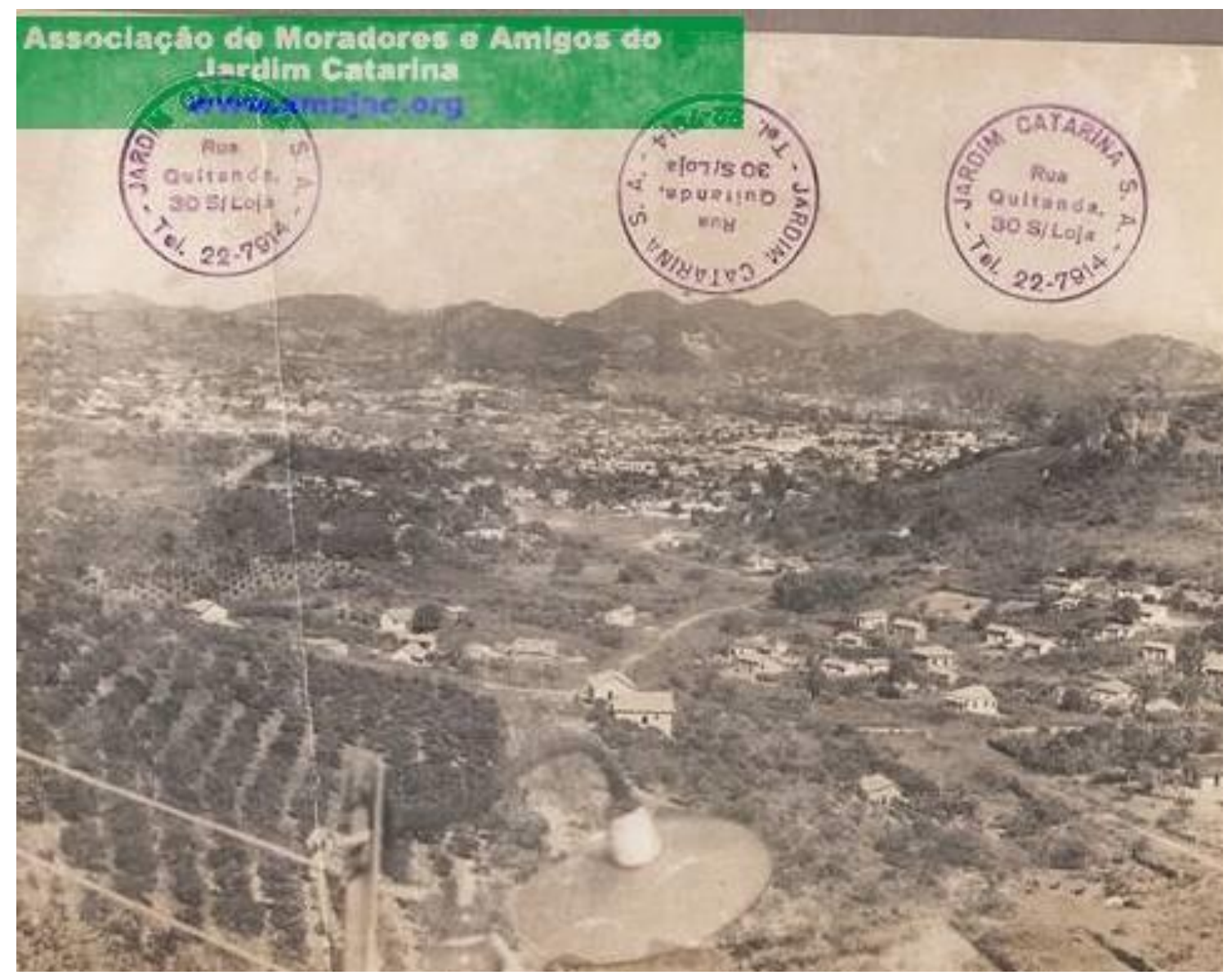

Fonte: Associação de Moradores e Amigos do Jardim Catarina.

É imprescindível considerar a atuação integrada dos grupos sociais em cada fase de reestruturação na dinâmica de produção do espaço urbano. Por grupos sociais vamos considerar a proposta de Corrêa, que os identifica como: os proprietários dos meios de produção, os proprietários fundiários, os promotores imobiliários, o Estado e os grupos sociais excluídos $^{67}$ (CORRÊA, 1993). Na primeira fase da reestruturação a ação dos promotores imobiliários, responsáveis pela venda dos loteamentos,

67 Uma ressalva sobre grupos sociais excluídos a partir de MARTINS (2009): consideramos que esses grupos sociais estão precariamente incluídos na sociedade e por isso desigualmente desfrutam de bens e equipamentos urbanos públicos ou privados. Esses grupos ditos excluídos, são na verdade o que KOWARICK (2000; p. 35) chamaria de "moradores espoliados e trabalhadores explorados" e esses grupos constituem-se como componentes intrínsecos do processo de produção capitalista. Logo, estes não estão excluídos nem da produção do espaço nem das consequentes implicações desta produção. Chamaríamos de grupos sociais urbanos (considerando a diferença entre os mais diversos componentes sociais no urbano e a classe social através da qual participam ativamente do processo de produção). 
destaca-se pela tentativa de evidenciar o grau de urbanização da área loteada e os serviços disponíveis à utilização da futura população urbana residente. Tal iniciativa também reforça a inferência de que a citricultura fundiu o rural e o urbano em São Gonçalo contribuindo para a maturação da estruturação urbano-industrial a qual os proprietários fundiários passaram a conduzir as relações sociais de produção na reprodução do capital sob o domínio do urbano.

Como mencionado anteriormente, Soares (1962) considera que até a segunda metade do século $\mathrm{XX}$, os lucros com a atividade da citricultura justificavam o não interesse no parcelamento do solo suburbano. Todavia a partir do momento que esses proprietários encontram meios de ampliar seu capital na venda de terrenos urbanos e na abertura de bairros planejados, converter terra rural em urbana tornou-se o principal negócio da urbanização capitalista. Essa mudança nos rumos da atuação dos proprietários fundiários e dos agentes imobiliários efetivava-se no papel do Estado como ente regulador das relações sociais de produção (LOJKINE, 1979). E, no caso de São Gonçalo, vimos na descrição de Machado sobre o processo de eletrificação do bonde no trecho para Alcântara, um exemplo da sutileza com a qual a natureza dessas relações transforma-se e produz rupturas, ao mesmo tempo que continuidades, no espaço.

O lançamento dos loteamentos urbanos de Jardim Catarina (imagem 19) destacava a centralidade já exercida pela localidade de Alcântara na região loteada (imagens 20 e 21 ) e, apresentando a proximidade com o importante centro comercial e de integração com as demais localidades de São Gonçalo e Niterói como fator responsável pelo sucesso do empreendimento. Se por um lado a citricultura retardou a onda de loteamentos que marcaria a primeira reestruturação urbana, também impulsionada pela integração metropolitana dada a possibilidade de intensificação de fluxos (moradia/transporte/trabalho), esta atividade também garantiu a manutenção do domínio dos grandes proprietários dos 
meios de produção na transição rural para o urbano e reproduziu as contradições de uma estrutura agroexportadora, do limite de sua realização até à industrialização como forma determinante das novas relações sociais de produção. 
Imagem 19 - Folder de lançamento do loteamento de Jardim Catarina (década 1950). O loteamento deu origem a um dos bairros mais populosos de São Gonçalo e consolidou-se na geografia histórica da urbanização de São Gonçalo como "área de risco" e de "bairro precário".
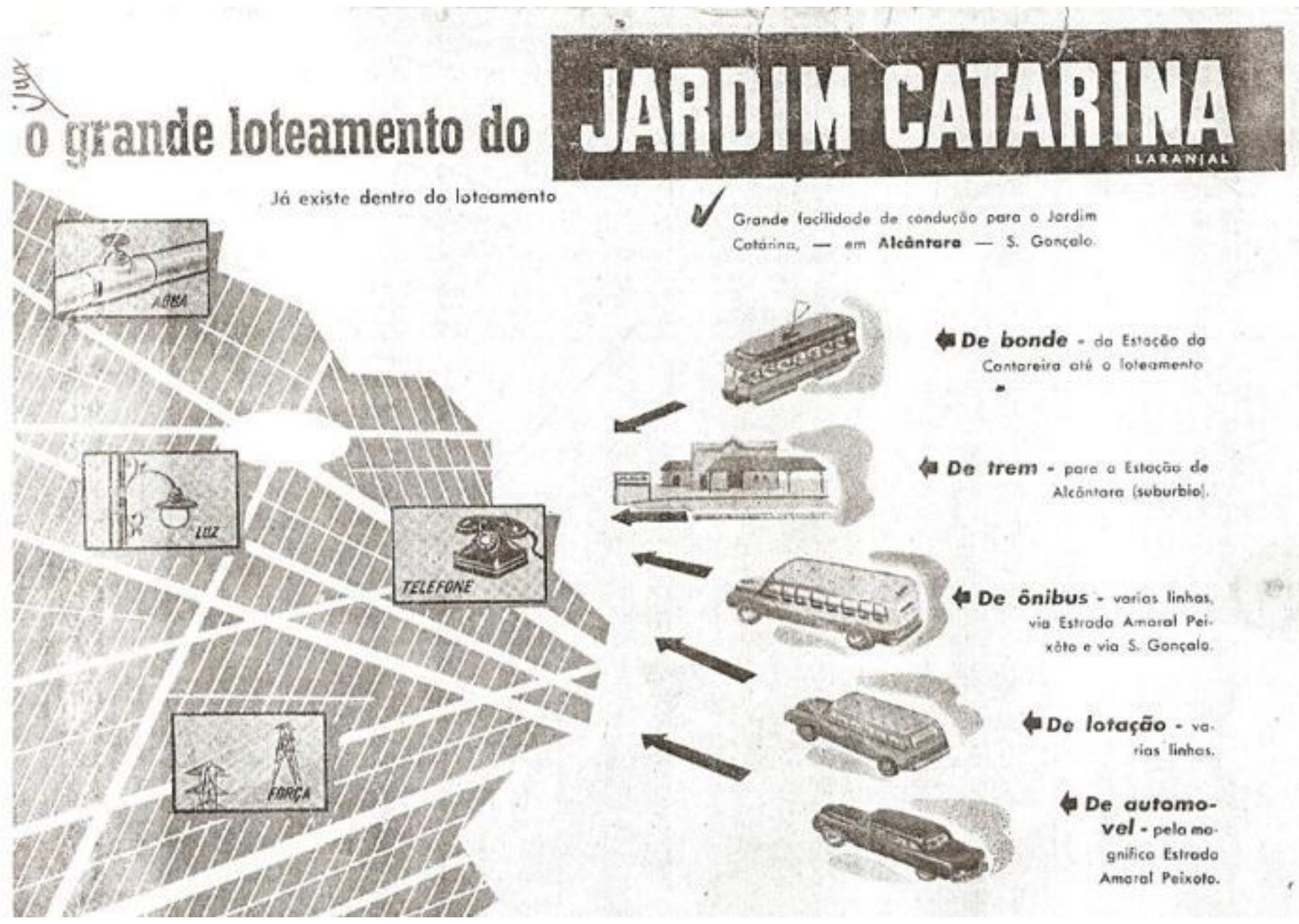

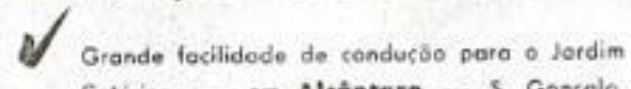
Cotárina, - em Alcântare - \$. Gonçalo.

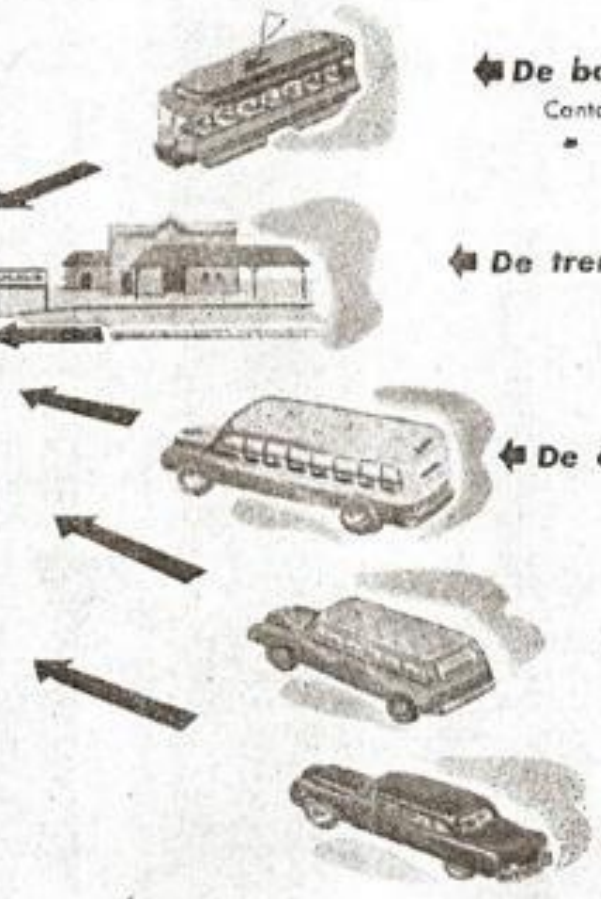

bonde - do Estosōo do Contareira até o loteamento

trem - pợe o tulộầo de Alcôntare (suburbio!)

Fonte: Associação de Moradores e Amigos do Jardim Catarina 
Imagens 20 e 21 - Instalações comerciais e de infraestrutura existentes no início do período de loteamentos do atual bairro Laranjal (1940-1950).
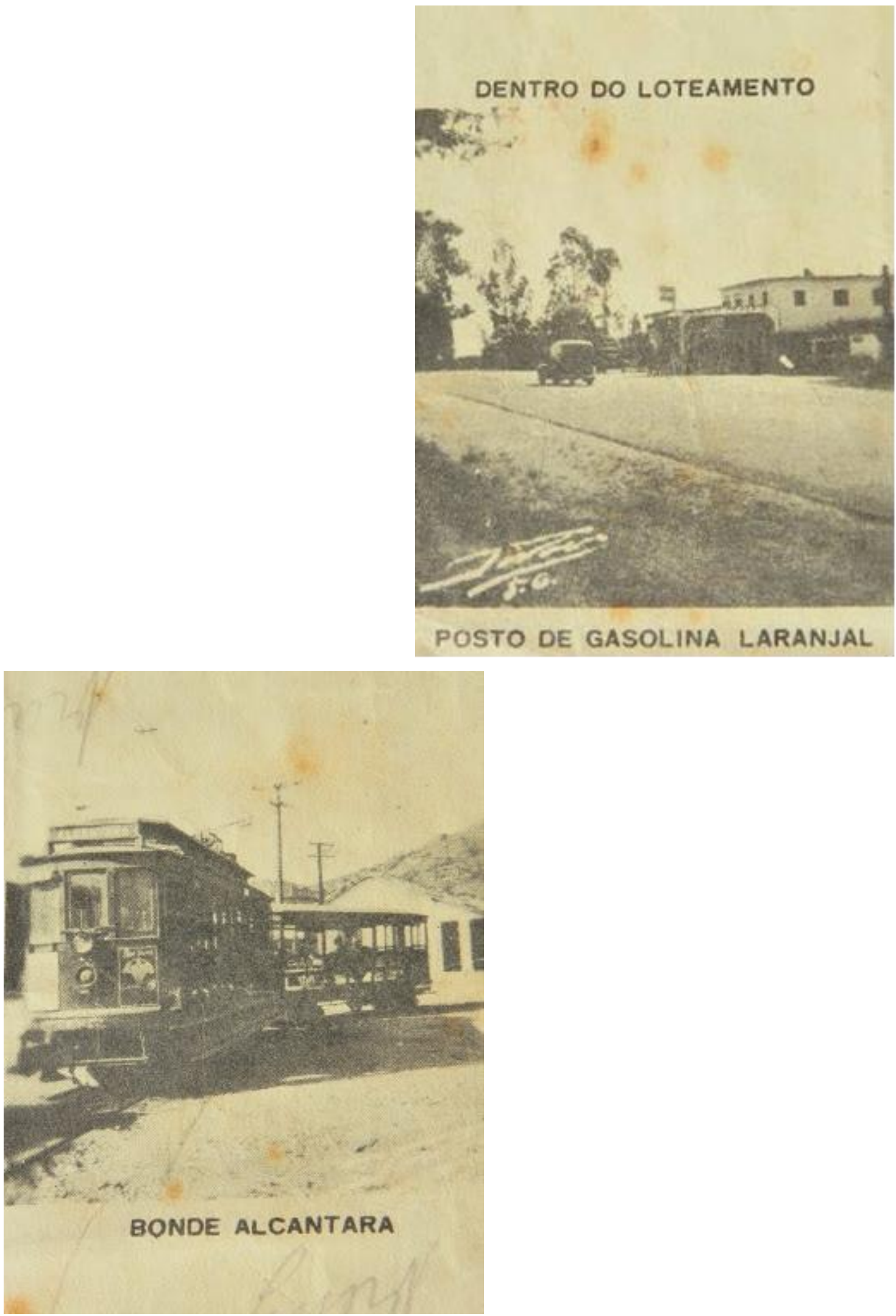

Fonte: Associação de Moradores e Amigos do Jardim Catarina 
Motta (1997) $)^{68}$ nos acrescenta elementos para compreender a importância da agricultura cítrica na produção do espaço em São Gonçalo. A autora, referindo-se ao processo emancipatório que tornou São Gonçalo em município, separando-o de Niterói em 1890, chama-nos a atenção para o fato de que autonomia administrativa alcançada articulava-se com os interesses políticos e econômicos dos agentes hegemônicos da região: "um novo município para uma antiga elite rural" (MOTTA, 1997; 179). A formação de um novo município possibilitou a manutenção da classe dominante na região de São Gonçalo e Niterói na virada para o século XX e seu protagonismo na dinâmica de produção do espaço, primeiramente, por meio da atividade agrícola e, sem seguida, pela influência das classes tradicionais no direcionamento dos investimentos e capitais externos (fossem nacionais ou internacionais) para o desenvolvimento da atividade industrial.

A urbanização característica da primeira fase da reestruturação do espaço em São Gonçalo processou-se em dois vetores complementares orientados pelas relações sociais de produção: o rural-cítrico e o urbanoindustrial, com a subordinação do primeiro em relação ao segundo. Com o apogeu da citricultura, a industrialização converte-se na principal determinação das relações sociais de produção e imprime um novo ritmo à urbanização de São Gonçalo, principalmente entre as décadas de 1940 e 1960.

São Gonçalo possuía, no início da década de 1940, ao menos 203 indústrias registradas. Na década de 1950 seu parque industrial se caracterizava pela diversidade de produção, destacando-se as

\footnotetext{
${ }^{68}$ Em MOTTA e KNAUSS (1997) encontramos a descrição dos processos que contribuíram para a formação da cidade de Niterói, sua busca por autonomia política e econômica ante à Capital Federal, seus espaços e tempos desde a elevação da Cidade à Capital do Estado à perda desta função, passando por temas como indústria naval, classes operária e elite rural. Nestes temas debatidos, o município de São Gonçalo aparece, no âmbito de seu decurso emancipatório, ora eclipsado, ora como coadjuvante no processo de desenvolvimento da região oriental da Guanabara.
} 
metalúrgicas, as de produção de cimento e cerâmica, químicas e farmacêuticas, de papel, papelão e vidro, alimentícias, brinquedos, dentre outras (BRAGA, 2006). É nesse contexto de desenvolvimento urbanoindustrial que todo o município, através da impressa local e regional, ganha o apelido de "Manchester Fluminense" ${ }^{69}$ devido a visibilidade econômica que passou a desfrutar após a instalação e consolidação de suas áreas industriais diversificadas. A ideia de subúrbio industrial foi construída com base em um discurso de prosperidade e de expectativas de desenvolvimento urbano no âmbito da reprodução da Metrópole Rio (imagens 22 e 23).

${ }^{69}$ A expressão Manchester fazia alusão a cidade inglesa que foi pioneira na utilização de máquinas a vapor na indústria têxtil e também no transporte de passageiros em ferrovias. No Rio de Janeiro, o município de São Gonçalo foi considerado a Manchester Fluminense. Em Minas Gerais, Juiz de Fora (Manchester Mineira) e, em São Paulo, Sorocaba (Manchester Paulista) são também alguns exemplos. 
Imagens 22 e 23 - São Gonçalo, a Manchester fluminense: capa e editorial da Revista Vida Fluminense
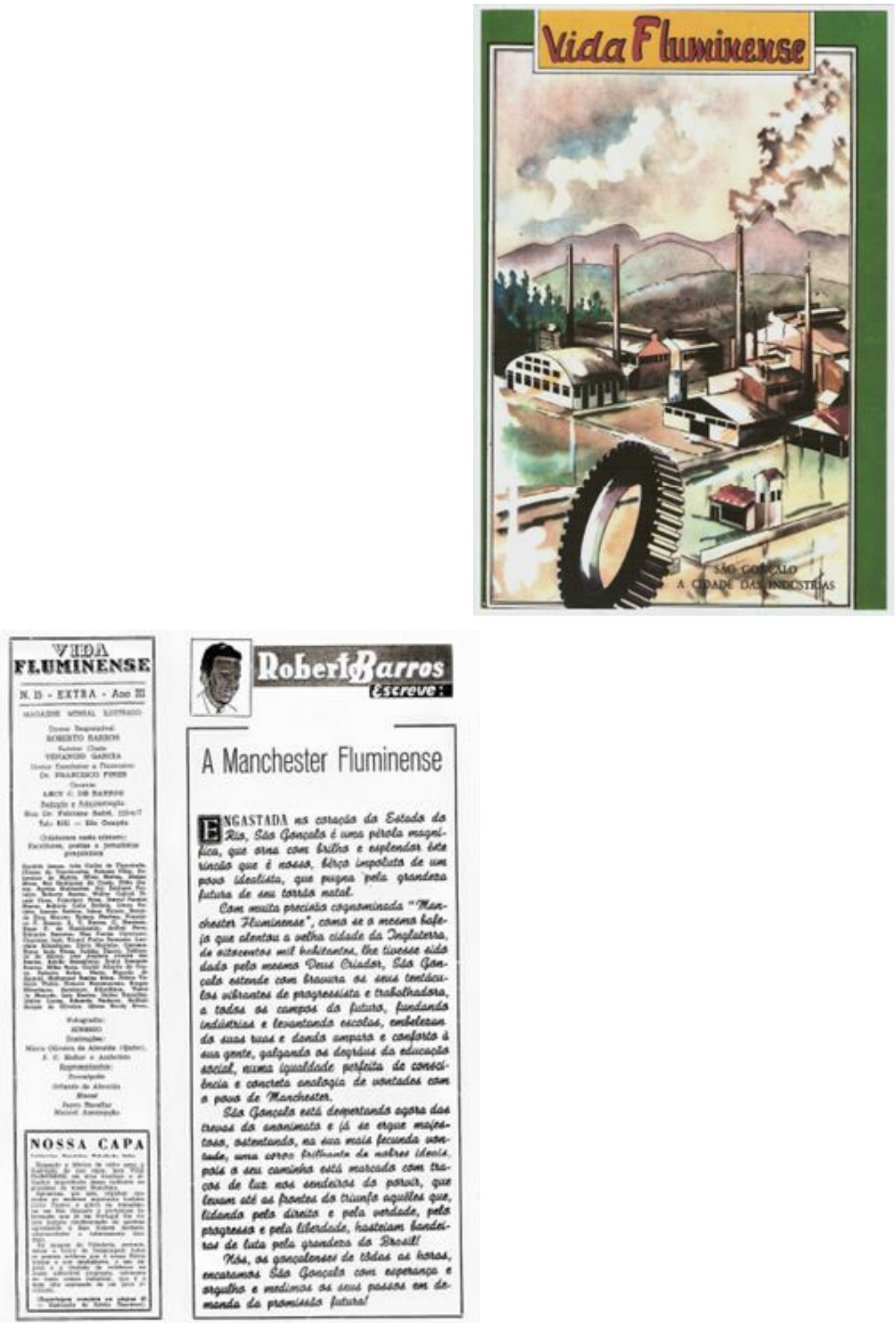

A Manchester Fluminense

Figastadia ns estapla da Eulada do

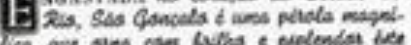

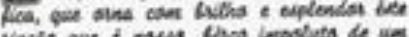

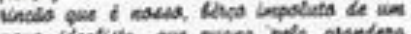

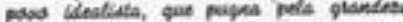

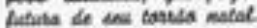

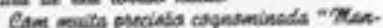

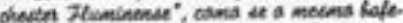

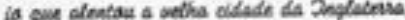

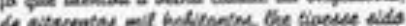

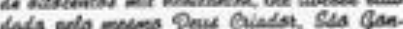

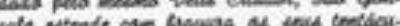

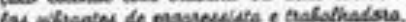

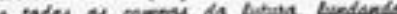

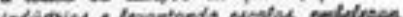

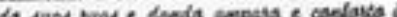

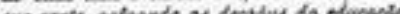
mo

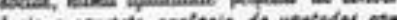

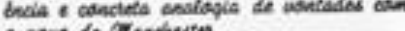

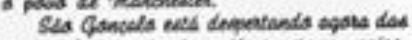

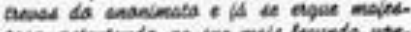

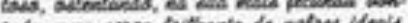

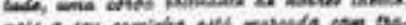

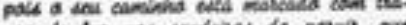

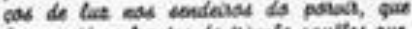

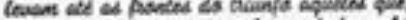
fulenda pets dowita e pola weteds, pols

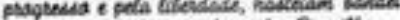
ied ie luta pels gondess da sande

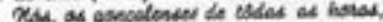

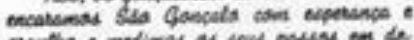

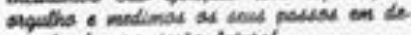
mende is plowivila pation

Fonte: Revista Vida Fluminense. No 15. Ed. Extra, Ano III. 1959. Capa e p.3. 
Lefebvre ao tratar da urbanização completa da sociedade, considera que seu curso se dá a partir de modalidades de urbanização e "cabe ao analista descrever e discernir [tais] tipos de urbanização e dizer no que se tornaram as formas, as funções, as estruturas urbanas transformadas" (LEFEBVRE, 2008, p. 26). Essas modalidades poderiam ser consideradas a partir das características da própria sociedade mediante o curso da industrialização em diferentes contextos. Tomando como referência analítica a realidade de São Gonçalo, destacamos que essas modalidades da urbanização podem ser assim apresentadas: I. uma urbanização que precede à industrialização e a gesta; II. uma urbanização que é capturada pela industrialização; III. uma industrialização que permite novos rumos da urbanização; e, IV. uma nova fase da urbanização no contexto metropolitano. Todas essas modalidades realizam-se no curso da urbanização e podem ser apreendidas em cada uma das fases de reestruturação aqui propostas. Passemos a segunda fase.

Os anos 1970 foram o marco de uma importante ruptura nas relações sociais de produção que, já consolidadas na grande indústria, ganham novos conteúdos orientados por práticas político-econômicas, precisamente as neoliberais que tornam possível a transição do regime de acumulação fordista para o regime de acumulação flexível. Essa ruptura proporcionada por transformações econômicas como resposta à necessidade de repensar as estruturas produtivas da industrialização em curso e efetivadas mediante um conjunto de políticas estatais que flexibilizaram as condições do desenvolvimento capitalista.

Nesse contexto, escalonado por dimensões globais, apresentamos a segunda fase de reestruturação no espaço em São Gonçalo, ainda que sob determinação urbano-industrial, as relações sociais contidas nessa fase do processo passam por significativas transformações. A segunda fase marca a maturação da determinação industrial no desenvolvimento urbano e abre caminhos para a gestação de novas tendências espaciais. 
A chamada reestruturação produtiva, instaurada no início da década de 1970 - com o objetivo de flexibilizar os mercados de trabalho e de consumo, as fronteiras comerciais, o controle da iniciativa privada pelo Estado e os fundamentos da produção - provoca um rearranjo espacial na determinação industrial da produção, altera as relações sociais e reestrutura o espaço urbano no qual e pelo qual tal determinação se tornou possível. Isso porque, adotada uma nova metodologia de produção e de distribuição mais rápida e dispersa, fez-se necessária uma outra divisão territorial da atividade produtiva e do trabalho, como por exemplo, a desverticalização da produção, a subcontratação de empresas e a utilização de uma força de trabalho polivalente (PINTO, 2013).

Para Duménil e Lévy "a acumulação de um conjunto de novos desenvolvimentos justifica, sem dúvida, alguma referência à noção de fase" (DUMÉNIL; LÉVY, 2003, p. 18). A segunda fase de reestruturação aqui proposta é, em nosso entendimento, o período de consolidação do conjunto do desenvolvimento urbano-industrial. As características desse período constituem aspectos novos, mas já embrionados, pois cada fase da periodização privilegia um tipo particular de processo que dá o limiar das rupturas, mas, ao mesmo tempo, permite apreender a continuidades contidas na produção-reprodução do espaço.

A crise produtiva pela qual o Estado do Rio de Janeiro passou entre anos 1970 e 1980, no contexto da reestruturação produtiva e do fortalecimento das políticas neoliberais, e também os impasses políticoadministrativos do território da cidade do Rio de Janeiro com a transferência do poder federal para Brasília, culminando na criação do estado da Guanabara (1960-75) e posteriormente na fusão deste com o estado Rio de Janeiro, constituem-se como elementos reestruturadores do arranjo espacial fluminense: o urbano e o regional tornam-se indivisíveis na dinâmica de produção do espaço. Após a fusão dos estados da Guanabara e do Rio de Janeiro, aprovada pela Lei Complementar $n^{\circ} 20$ de 
julho/1974, também foi criada a Região Metropolitana do Rio de Janeiro (RMRJ), na qual São Gonçalo se inseriu deste a institucionalização.

A consolidação da estrutura metropolitana pela via institucional, um importante instrumento político de produção do espaço, surtiu como uma possibilidade de manobrar as continuidades mesmo em contexto de ruptura. A reestruturação produtiva não pós fim a estrutura urbanoindustrial, mas a realizou até o limite de suas oportunidades produtivas. 0 espaço urbano produzido nesse movimento vai transformar-se.

A Região Metropolitana do Rio de Janeiro, criada um ano após a criação das primeiras regiões metropolitanas do Brasil, não amenizou os embaraços derivados do progressivo crescimento da população concentrada na Metrópole Rio e na sua região (especialmente nos municípios de São Gonçalo, Nova Iguaçu e Duque de Caxias); a crise produtiva do estado e os subsequentes fechamentos de indústrias nos subúrbios metropolitanos (ou a transferência destas para outros municípios no interior do estado do Rio de Janeiro ou fora dele), acompanhou-se de uma onda de desempregos, aumento da informalidade e precarização das condições de vida na cidade industrial.

Esses agravamentos absorvidos na estrutura urbano-industrial concentraram investimentos e melhoramentos no núcleo metropolitano. Esse momento de mudanças indica que a reestruturação capturou espaços centrais da metrópole e conduziu a cidade de São Gonçalo a conformar-se como periferia metropolitana (ROSA, 2018), capturando-a por meio de um discurso de precarização suficientemente indutor da expansão territorial do processo de regionalização metropolitana, redefinindo novos espaços de serviços urbanos, trabalho e produção até a década de 1990.

Se a primeira reestruturação do espaço em São Gonçalo permitiu e orquestrou o desenvolvimento da função industrial; nessa segunda fase, 
entretanto, observa-se não só o processo de desindustrialização ${ }^{70}$ como condição e resultado de novas relações sociais de produção. De cidade industrial à cidade dormitório. São Gonçalo passa a contar com os centros comerciais de Niterói e Rio de Janeiro, pois são para essas cidades que grande parte da população economicamente ativa desloca-se para os postos de trabalho. Com o comércio pouco estimulado e diversificado, 0 fortalecimento do discurso de precarização na oferta de serviços e consumo, São Gonçalo tornou-se a expressão mais próxima da condição espacial periférica: baixa arrecadação, poucos serviços especializados, expansão urbana dispersa e pulverizada. A Metrópole Rio explodiu em todas as suas contradições e continuidades perversas do modo de produção que produz o espaço necessário à sua reprodução ampliada.

Alguns autores, como Lessa (2009), defendem a negação de um cenário de crise econômica e industrial no município de São Gonçalo, no período pós-1960, porque consideram o surgimento e a consolidação de ramos industriais tais como o farmacêutico ${ }^{71}$ e o de confecção (indústria da moda) como os mais importantes na dinâmica produtiva de São Gonçalo desde então. O autor não parece considerar que esses dois ramos industriais são, entretanto, os mais afetados pela reestruturação produtiva internacional. Se considerarmos, por exemplo, o número de confecções da indústria da moda na Região Metropolitana do Rio de Janeiro, São Gonçalo figura o segundo lugar (3.690 empresas cadastradas no setor têxtil e confecções), de acordo com a Federação das Indústrias do Rio de Janeiro (Firjan). Porém, essa atividade vem sendo desenvolvida na forma de Arranjos Produtivos Locais (APL) que, articulados fortemente aos interesses dos empresários e organizado por meio de um aparato legal,

\footnotetext{
70 Utilizamos o termo "desindustrialização" considerando que seu entendimento mais abrangente está associado não só à quantidade de estabelecimentos industriais como ao número de trabalhadores empregados neste setor, uma vez que o processo de industrialização envolve não só a dinâmica de produção, como também as relações de trabalho e a formação de uma classe trabalhadora.

71 Lessa (2009), considera a atuação do grupo alemão B Braun do ramo farmacêutico (tecnologia cirúrgica, anestesias, neurocirurgia, coaptação de incisões, ortopedia etc). 0 grupo tem sede em São Gonçalo e atualmente investe na ampliação das suas instalações no Complexo Industrial e Empresarial de São Gonçalo (CIESG).
} 
reorienta as relações sociais de produção que, embora cada vez mais flexível para o modelo de acumulação, possuem também uma dimensão territorial cada vez mais racional, competitiva e coorporativa.

Lessa baseia-se na quantidade de estabelecimentos industriais existentes ou que se mantiveram em funcionamento pós-1960 até os anos 1990, alegando que tais números sustentavam o município de São Gonçalo no ranking dos mais industrializados do Estado do Rio de Janeiro. Todavia, o autor não considerou o crescimento populacional (tabela 9) que o município obteve ao longo dessas décadas e a incapacidade do setor industrial frente à demanda por empregos, tão pouco a renovação tecnológica que influenciou na manutenção de postos de trabalho no setor secundário deslocando para o terciário grande parte da demanda; demanda essa absorvida pelas cidades de Niterói e Rio de Janeiro.

Tabela 9 - População residente no município de São Gonçalo (19401991)

\begin{tabular}{c|c|c|c|c|c|c}
\hline & \multicolumn{6}{|c}{ População residente } \\
\cline { 2 - 7 } São Gonçalo & 1940 & 1950 & 1960 & 1970 & 1980 & 1991 \\
\cline { 2 - 7 } & 85.521 & 127.276 & 247.754 & 430.271 & 615.352 & 779.832 \\
\hline
\end{tabular}

Fonte: Fundação CEPERJ

Nas décadas de 1940 e 1950, nas quais a industrialização aqueceu a oferta de emprego, São Gonçalo possuía uma população de 85.521 e 127.276 habitantes, respectivamente. Enquanto que na década de 1960 o crescimento populacional atingiu a marca de $290 \%$ a mais em relação a 1940, e chegou a $900 \%$ em 1991. Estamos diante de uma explosão demográfica nos subúrbios metropolitanos do Rio de Janeiro e de um momento que se caracteriza pela supervalorização da metrópole em detrimento de suas áreas periféricas. Segundo Abreu:

É a partir dessa época também [que] o núcleo metropolitano passa a ser palco preferido para os melhoramentos urbanos, realizados tanto pelo Governo Federal como Estadual", 
concentrando os investimentos públicos e privados nas obras de infraestrutura tais como "tuneis, viadutos e autopistas [...] reforçando o contraste entre este $e$ as periferias metropolitanas. (ABREU, 2008; p. 30).

Se negarmos a desindustrialização ${ }^{72}$ de São Gonçalo, como sugere a interpretação de Lessa, arriscamo-nos perder um importante elemento de interpretação da produção do espaço urbano: seu movimento de realização. $O$ autor embora considere a relação indústria/produção/trabalho, sua análise é quantitativa: número de indústria e número de pessoal ocupado. Lessa não discute a qualidade dessa tríade e tão pouco discorre teoricamente sobre os conceitos de desindustrialização e reestruturação (em suas diversas adjetivações), embora os utilize.

Consideramos que nesse período São Gonçalo passa por uma maturação da estrutura urbano-industrial que inaugura uma sensível transição para um outro momento de sua urbanização. Esta transição é sensivelmente percebida se analisarmos as relações que envolvem a tríade acima mencionada, indústria/produção/trabalho. Harvey, ao descrever as transformações ocorridas na cidade de Baltimore, relaciona esses elementos na discussão da desindustrialização na cidade:

Rápida transição das oportunidades de emprego. Os empregos industriais tiveram acelerado seu deslocamento [...]. Os estaleiros, por exemplo, praticamente se aproximaram do desaparecimento, e as indústrias que permaneceram reduziram os empregos. [...] Surgiram empregos no setor de serviços para substituir as cerca de 250 mil vagas perdidas nas operações industriais e portuárias. (HARVEY, 2009; p. 192).

Harvey parece utilizar o termo desindustrialização pautando-se, além do efetivo fechamento das unidades industriais, da oferta de

72 O termo desindustrialização, aqui empregado, não só faz referência a quantidade de estabelecimentos industriais quanto ao número de trabalhadores empregados neste setor, uma vez que o processo de industrialização envolve não só a dinâmica de produção de mercadorias, como também as relações de trabalho, a formação de uma classe trabalhadora e sua reprodução social e a produção de um espaço que realiza todas essas relações. 
empregos oferecidos à população residente. Ele aponta também para a degradação da paisagem urbana diante dos vazios industriais que prevalecem à espera de reutilização.

No período da primeira reestruturação em São Gonçalo predominavam na paisagem as grandes indústrias e sua lógica disciplinadora do tempo e do espaço. A paisagem urbano-industrial de São Gonçalo respondia à incorporação da técnica ao território e articulava-se à produção através da ferrovia, dos portos, dos telégrafos, dos bondes (ARAÚJO, 2002). A paisagem urbano-industrial que perdurou até a década de 1960 em São Gonçalo começou a ser transformada tanto em sua forma como em seu conteúdo, restando desse período as antigas estruturas espaciais da doutrinação operária (imagens 24 e 25). 
Imagem 24 - Conserva Piracema: vestiário e refeitório da fábrica ainda em funcionamento, mas com reduzido número de operários

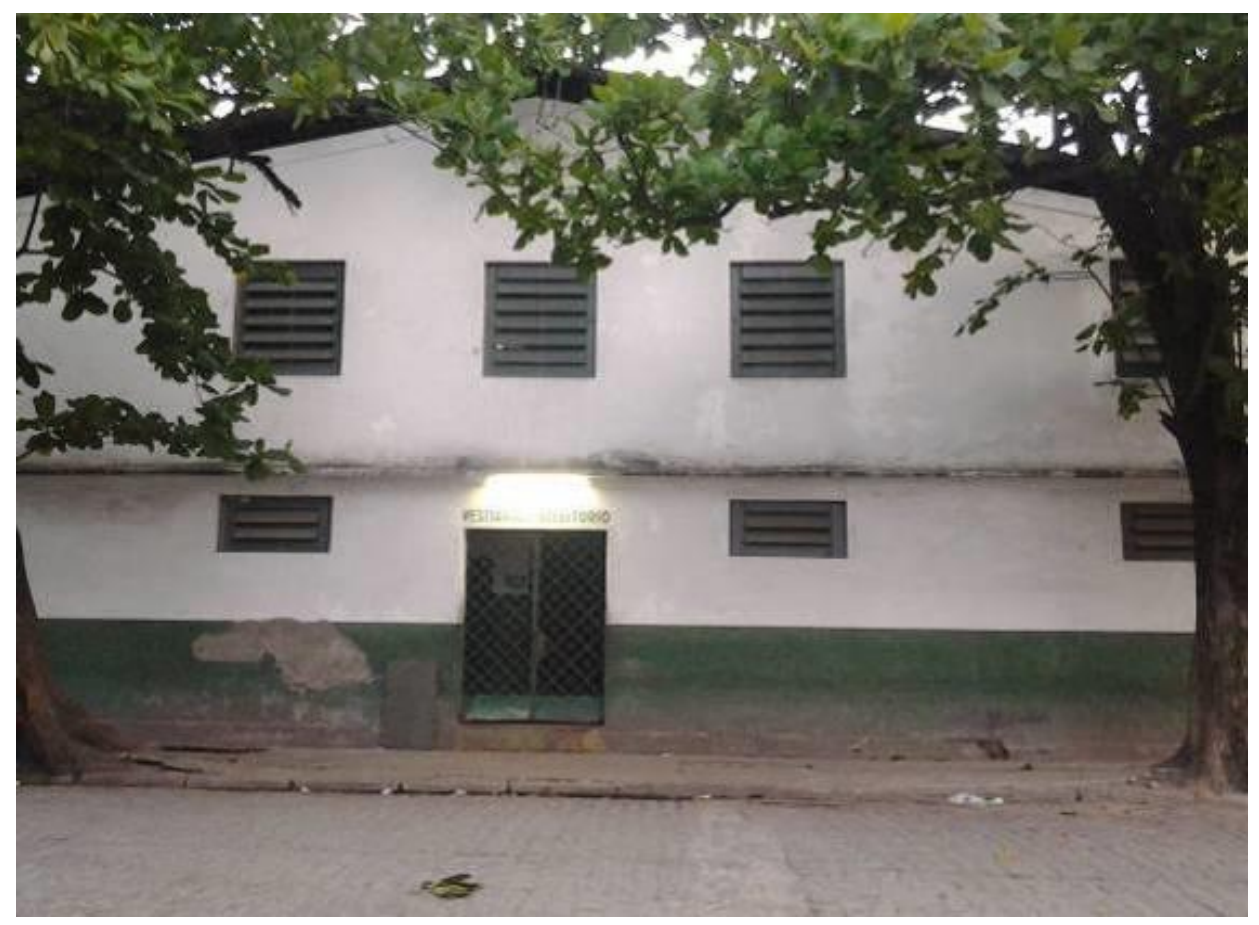

Imagem 25 - Conserva Piracema: salas administrativas, gestão e gerência de produção

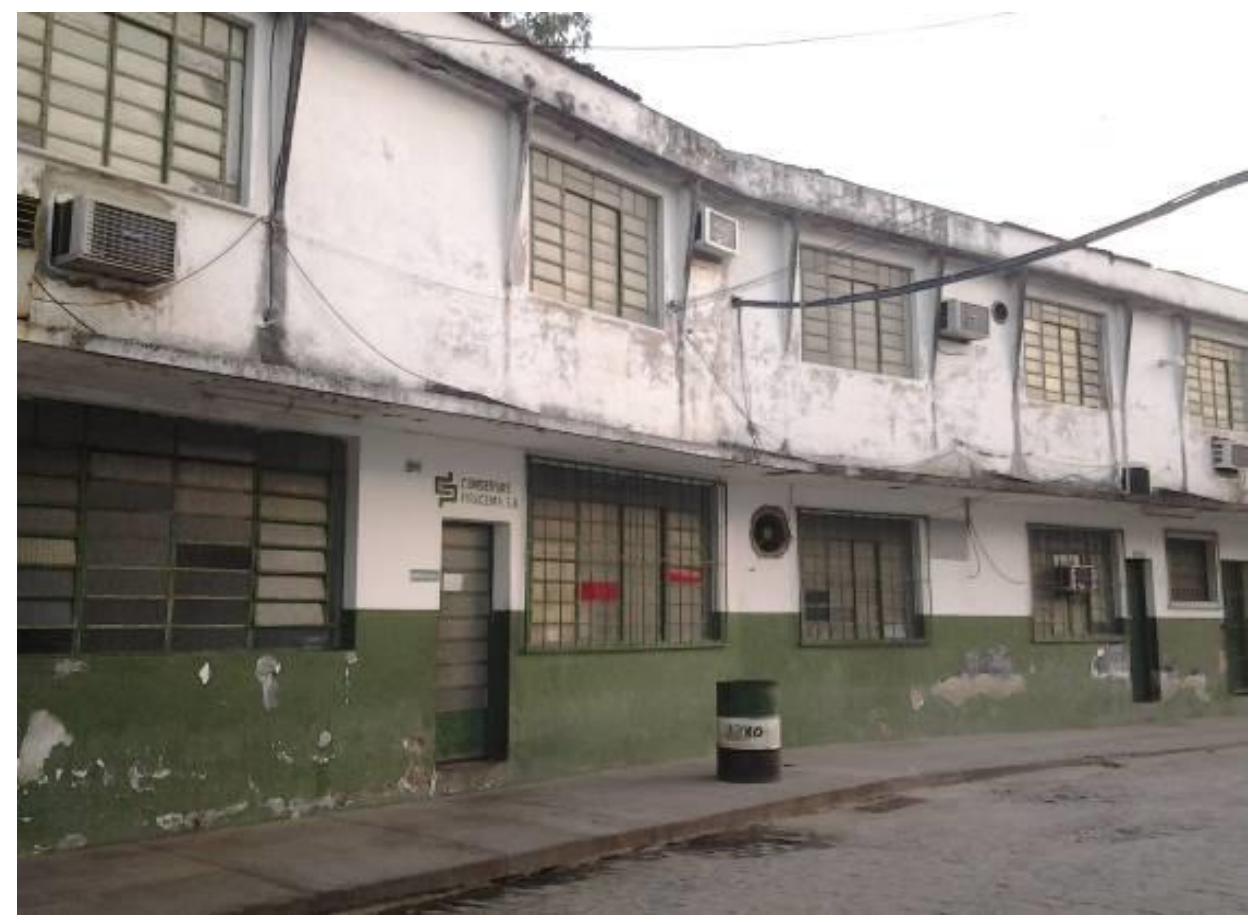

Crédito: Juliana Luquez 
A desindustrialização não se identifica na contemplação e observação da paisagem, mas na análise das relações que envolvem a regulação do trabalho, o cotidiano do trabalhador, e as lógicas que orientam a produção da cidade. Logo, a segunda reestruturação urbana em São Gonçalo é marcada por significativas mudanças no setor industrial e novas apropriações do espaço urbano conectado aos interesses e demandas do núcleo metropolitano.

Se antes predominavam as grandes fábricas, soavam os seus apitos ou os do trem comunicando ações e deveres cotidianos aos operários, a segunda reestruturação do espaço começa a ser possível no momento em que essas estruturas espaciais e sociais sofrem interferências de novas formas de dominação capitalista, conformando o espaço suburbano da metrópole em lócus de subordinação e dormitação temporárias, construindo áreas de reserva para o capital em novos momentos de reestruturação e garantindo o suprimento da maior demanda da Região Metropolitana em formação: moradia para a classe trabalhadora, explorada pelo processo de trabalho e espoliada pelo processo de urbanização. A segunda fase constitui-se, assim, uma reestruturação via espoliação urbana - como denuncia Kowarick e que anteriormente já tomamos por referência.

Nesse sentido, o uso e a ocupação do espaço urbano também sofrem intensas pressões por oferta de moradia. Neste período identificamos um crescimento significativo do número de conjuntos e unidades habitacionais construídos nos bairros da área de efetiva expansão urbana do município: Centro, Coroado, Boaçu, Nova Cidade, Porto da Pedra, Bairro das Palmeiras, Alcântara, Maria Rita, Brasilândia, Mutondo, Colubandê, Rocha, Gradim, Vila Lage (imagem 26). A maioria dos conjuntos erguidos nesses bairros foi construída entre as décadas de 1970 e 1980 com o incentivo do poder público (estadual e federal) e a iniciativa privada e direcionada à uma parcela ainda restrita da população assalariada ou quiçá aos servidores públicos. 
Imagem 26 - Vista para o bairro de Alcântara. Em segundo plano, os edifícios destinados à moradia construídos na década de 1970. Esse conjunto arquitetônico marcou a paisagem urbana de São Gonçalo como um novo conteúdo da urbanização contemporânea. Os processos de periferização e de segregação são reescalonados na segunda fase de reestruturação.

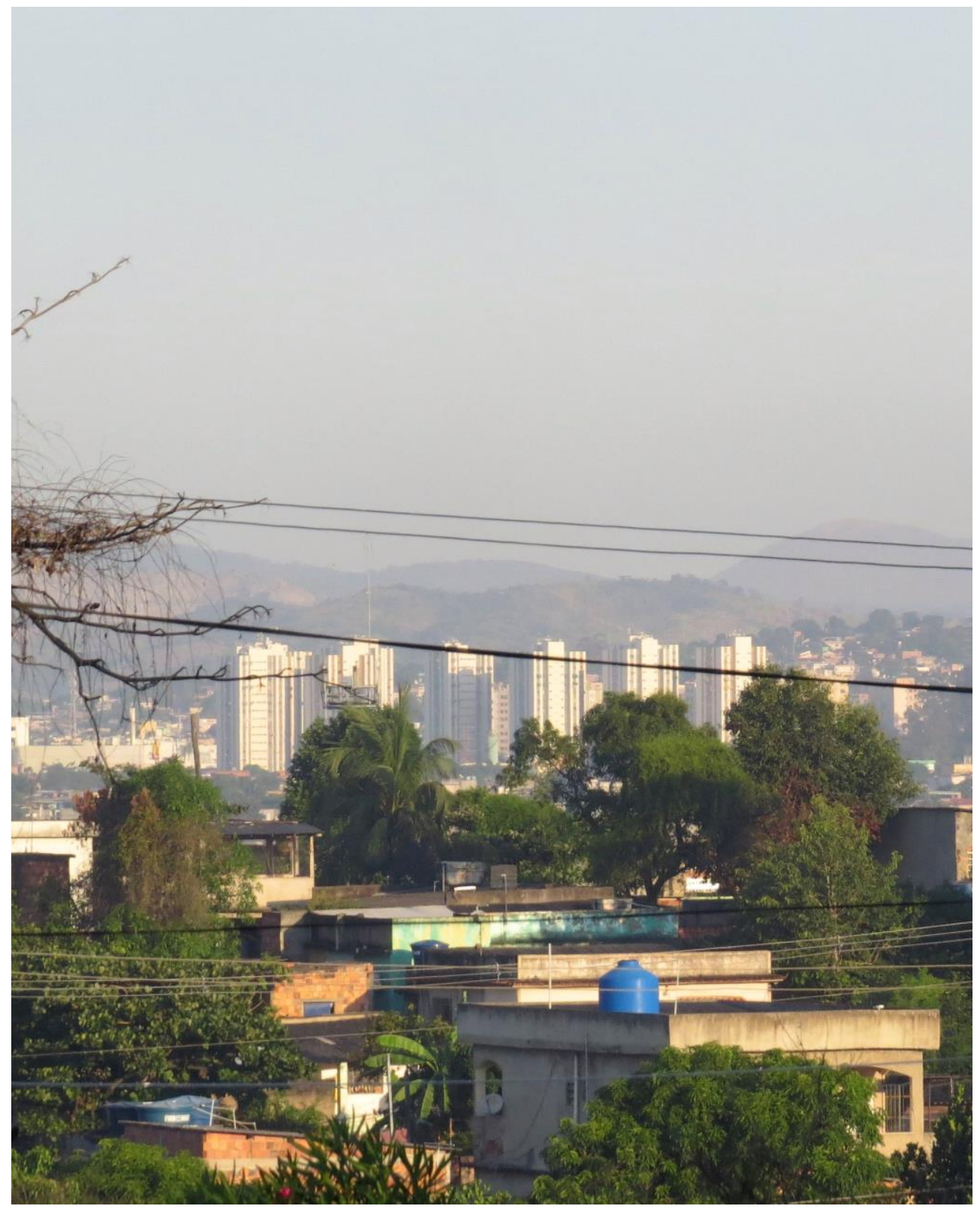

Crédito: Juliana Luquez

Não há espaço nessa seção para o aprofundamento acerca do uso imobiliário, quer para moradia ou segmentos do setor de serviços, que o tema merece (ressalva que também fizemos no capitulo anterior); contudo, por reconhecermos sua importância, o identificamos como elemento indispensável para se pensar a produção do espaço urbano de 
São Gonçalo durante a segunda reestruturação. Para tanto escolhemos um viés: o início do processo de verticalização do ambiente construído esse viés revelar mais sobre os conteúdos das formas espaciais do que a especificidades de suas funções urbanas.

A verticalização em São Gonçalo começou a ganhar destaque na paisagem urbana nos anos 1980. A expansão e a ocupação urbanas no município seguiram-se predominantemente no padrão horizontal, seja na ocupação residencial ou nas plantas industriais. Os sobrados, estes concentrados em localidades centrais para o desenvolvimento de atividades comerciais e de serviços, dividindo seus andares superiores com a moradia de quem os pudesse ocupar, atravessaram as décadas sendo os destaques arquitetônicos da estruturação urbana moderna do município. Os prédios de vários andares começaram a ser erguidos entre os anos 1970 e 1980, alguns destinados às moradias das políticas habitacionais que enobreceram, embelezaram e segregaram espaços na periferia metropolitana, hierarquizando-a ${ }^{73}$; outros tantos destinados às primeiras salas de escritório e serviços - a metrópole coorporativa lançava seus fundamentos para além de seus limites administrativos, sua região de influência se homogeniza.

A partir dos anos 1980, com a generalização do elevador, edifícios com mais de dez andares despontaram. Diferentes modalidades imobiliárias foram incorporadas à paisagem e ofertadas à aquisição de diversos compradores, desde moradia predial até centros de negócios. Durante anos dessa segunda fase o prédio mais alto era o de um banco do estado de Minas Gerais, o BEMGE, que possuía oito andares (imagem 27). O Banco do Estado de Minas Gerais encerrou suas atividades em São Gonçalo no ano de 1996, na onda de privatizações de bancos públicos

73 Segundo MAUTNER, as unidades habitacionais providas pelo Estado cumpriram um papel meramente simbólico de intervenção, pois destinavam-se majoritariamente às classes médias. Efetivamente, as políticas habitacionais objetivaram, por meio do sistema de crédito, "a organização e o fortalecimento da indústria da construção civil no setor habitacional e também a geração de emprego". Para a autora a "modernidade passa a ser entesourada na precariedade urbana da periferia" (MAUTNER, 2004, p. 249). 
estaduais ocorrida nos anos 1990. Atualmente São Gonçalo conta com 47 agências bancárias, sendo a quarta maior concentração de unidades bancárias na região metropolitana (juntamente com o município de Nova Iguaçu). Estamos diante de novas formas-conteúdo do urbano e de sua produção. No movimento contraditório toda a instabilidade contida nos momentos de uma estrutura, socialmente produzida e socialmente reestruturada, realizam os processos em curso e ativam novas dinâmicas espaciais.

Imagem 27 - Praça Doutor Luiz Palmier, Centro (década de 1980)

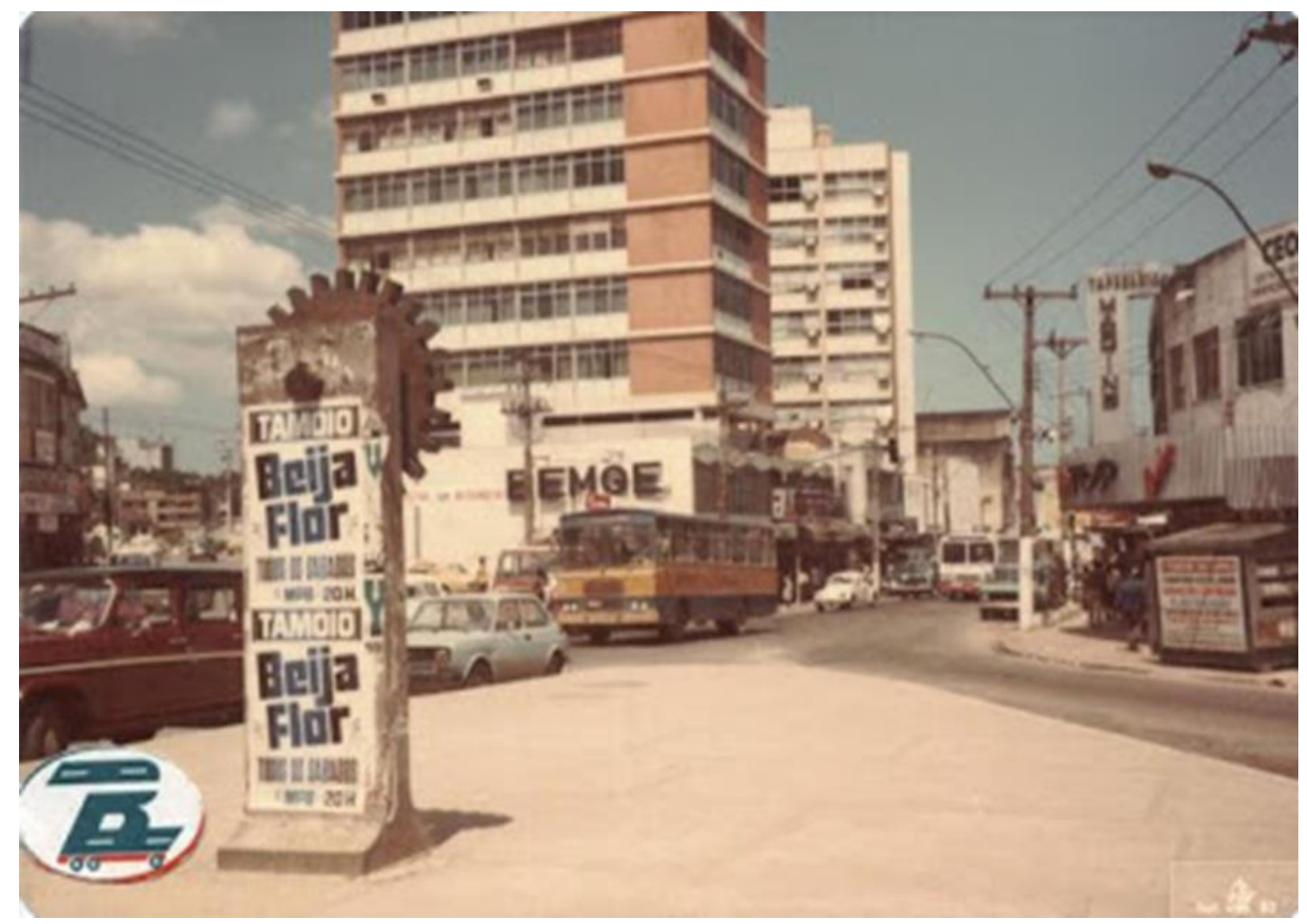

Fonte: Acervo Território Gonçalense.

Esse arranjo espacial apresentado como característico da segunda reestruturação do espaço perdurou até o início dos anos 1990. É então, no período pós-90, e especialmente a partir dos anos 2000, que uma nova ruptura marca a terceira fase de reestruturação do espaço em São Gonçalo. Novas centralidades se desenvolvem nas periferias metropolitanas do Rio de Janeiro. A paisagem urbana de São Gonçalo 
começa a sofrer mudanças significativas do ponto de vista dos novos padrões de empreendimentos que o município recebe.

Os antigos espaços industriais passam a se inserir nas novas dinâmicas do capital em escala regional e novas áreas da cidade ganham destaque para o mercado. Nessa fase os novos conteúdos da urbanização, apresentados anteriormente a partir de Carlos (2015), e as características da metropolização, apreendidas conforme Lencioni (2017), expressam-se explicitamente na dinâmica de produção do espaço em são Gonçalo. Uma ruptura radical insere novas determinações às relações sociais de produção. A estruturação urbano-industrial dá lugar a estruturação metropolitano-financeira. É possível observar que, dentro de outro contexto, uma nova reestruturação orienta o atual arranjo espacial: a necessidade de espaços de consumo: na cidade e de pedaços dela.

São Gonçalo passa a compor o mapa das centralidades locais e regionais inseridas neste contexto de transformação. Após alguns anos de predomínio de um discurso de precarização, o qual contribuiu para a manutenção de agentes hegemônicos na orientação de tais transformações (MODESTO, 2008), São Gonçalo entra no circuito de renovação da atuação do capital nas áreas periféricas e dispersas da urbanização metropolitana. As notícias de projetos de infraestrutura urbana, lançamentos imobiliários e de empreendimentos diversos são a grande novidade das propagandas publicitárias que promovem a cidademercadoria (imagens 28 e 29). 
Imagem 28 - Folder de lançamento imobiliário: primeiro apart hotel de São Gonçalo (2016)

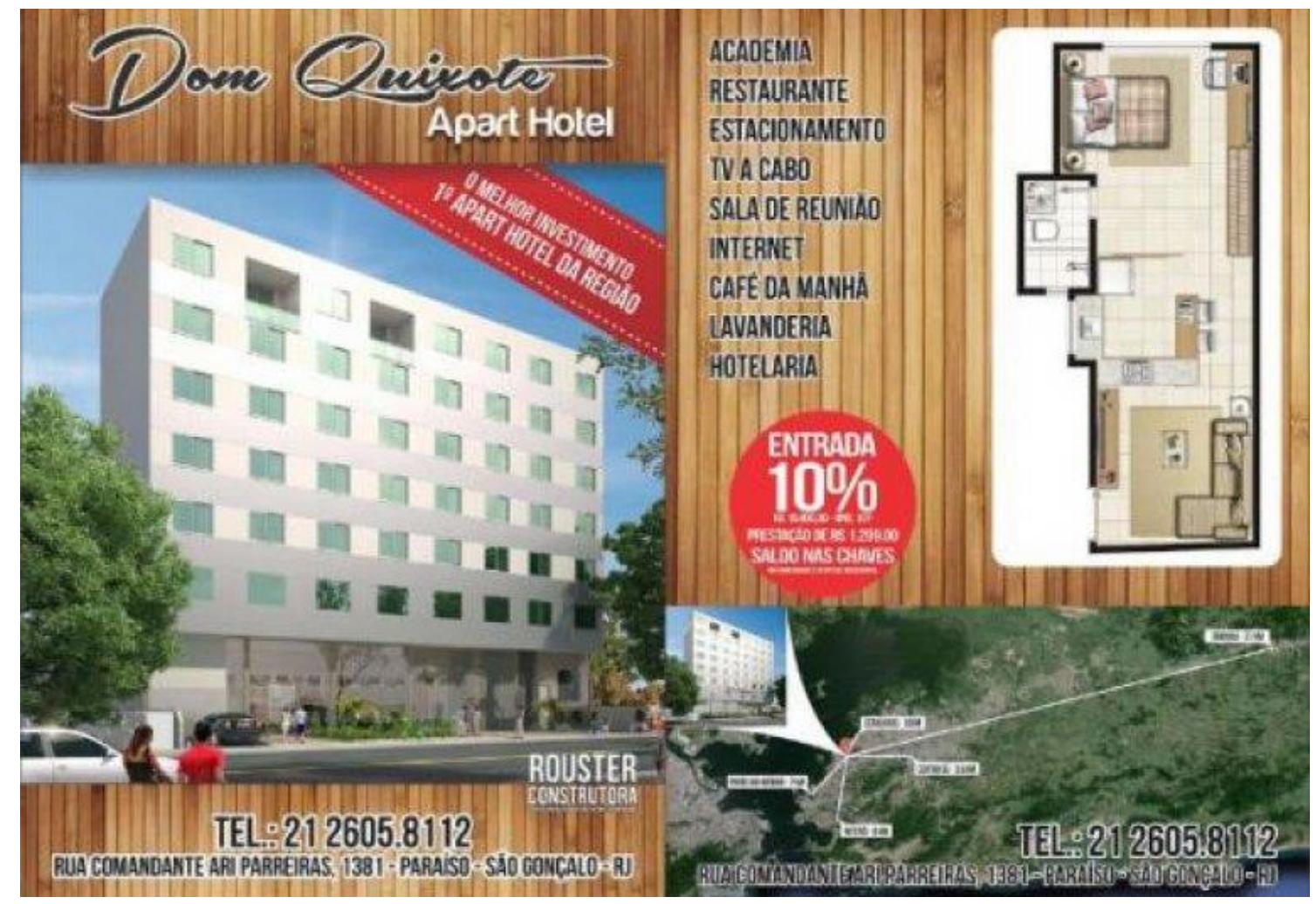

Imagem 29 - Página da internet do apart hotel Dom Quixote (2018)

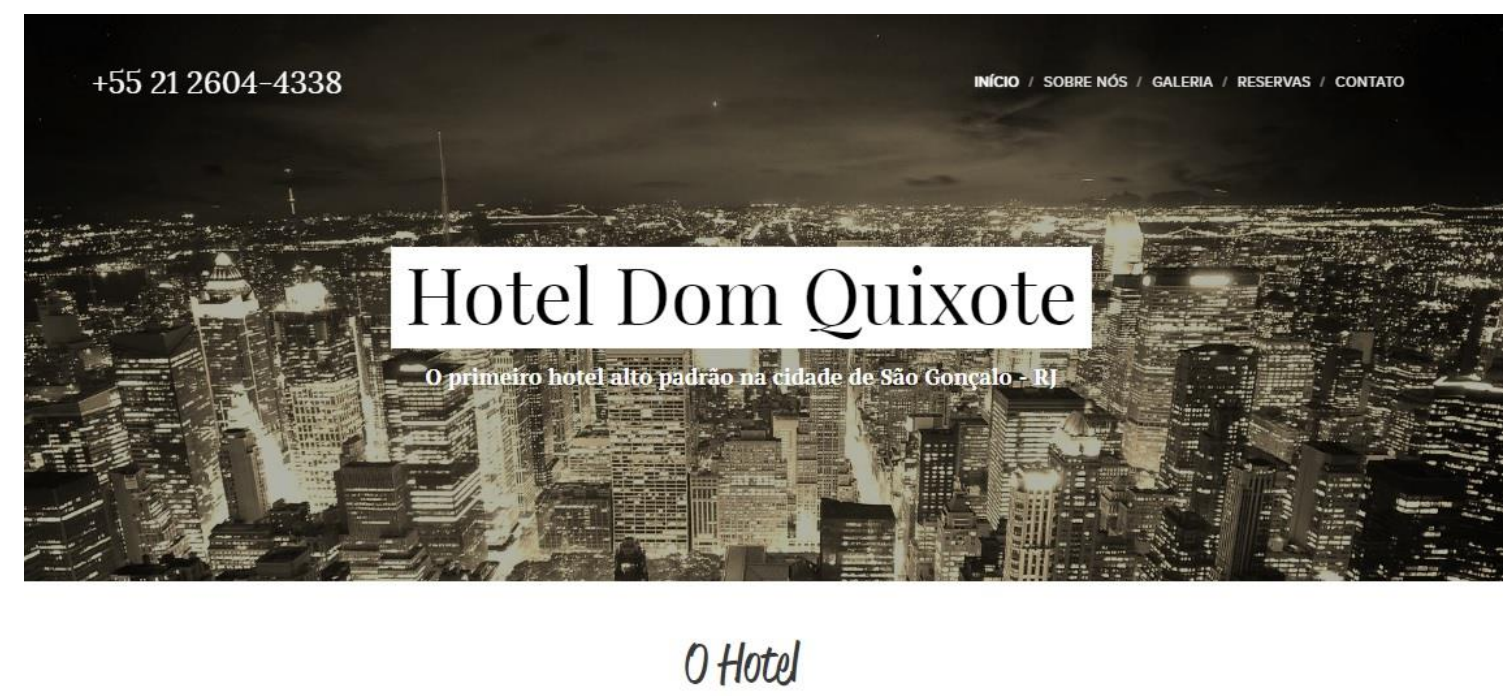

Situado a 3km do centro de São Gonçalo e a 9km do centro de Niterói, o Hotel Dom Quixote foi pensado no que há de melhor em acomodação e serviços para sua estada, sendo ela a lazer ou a negócios.

Fonte: Website Hotel Dom Quixote (https://www.hoteldomquixote.com.br/) 
Como já destacado anteriormente, São Gonçalo atraiu nos últimos 15 anos, três empreendimentos imobiliários do tipo shopping center e um projeto de construção para um quarto. O terceiro shopping center, inaugurado em 2013, foi erguido na área central do bairro Alcântara. O empreendimento conta com 81 lojas, praça de alimentação, terraço panorâmico e terminal rodoviário. Esse empreendimento foi erguido no local ocupado pela tradicional Praça Carlos Gianelli, em frente a Igreja São Pedro de Alcântara, e aniquilou a amenidade para a circulação de pedestre na localidade, destruindo um espaço público em prol da concessão do privado (imagens 30 e 31 ).

As novas dinâmicas socioespaciais, pelas quais os municípios metropolitanos fluminenses vêm passando, inserem os processos de concentração e centralização do capital na atual lógica de produção dos espaços metropolitanos, agindo em diferentes níveis (global, regional, local) e dimensões (espacial, social, econômica, política) e determinando novos mapas às mesmas localidades. Sobre esse aspecto, Lencioni fala em reestruturação imobiliária, considerando o setor imobiliário como determinante na estruturação do espaço da atual sociedade.

Com esse sentido, de emergência de uma nova estrutura que se impõe sobre a anterior, é que falamos em reestruturação imobiliária, uma vez que uma nova estrutura se impõe sobre a anterior e modifica profundamente o setor imobiliário. Essa reestruturação imobiliária implica a reestruturação do próprio capital investido no setor, a reestruturação de tudo que envolve a construção - a exemplo das profundas transformações no canteiro de obras e na profissão do arquiteto e na reestruturação da propriedade da terra, por meio do surgimento de novas formas de propriedade, tais como o leasing imobiliário e o time-sharing ${ }^{[74]}$. [...] dois aspectos consideramos chaves para a compreensão dessa restruturação. São eles: o processo de concentração do capital e o de centralização do

\footnotetext{
74 Trata-se, respectivamente, de um meio de financiamento acordado através de um contrato de locação financeira, onde existe um locador que disponibiliza o uso de um bem ao locatário (o cliente), que paga uma renda e de oferecer o direito de ocupação de um imóvel, como um quarto de hotel ou casa de férias, durante um determinado período de tempo; este modelo permite que múltiplos usuários possam usufruir dos benefícios de um mesmo imóvel sem ser dono dele.
} 
capital no setor imobiliário. (LENCIONI, 2017, p. 110 - grifos da autora).

Imagem 30 - Shopping Pátio Alcântara (2016)

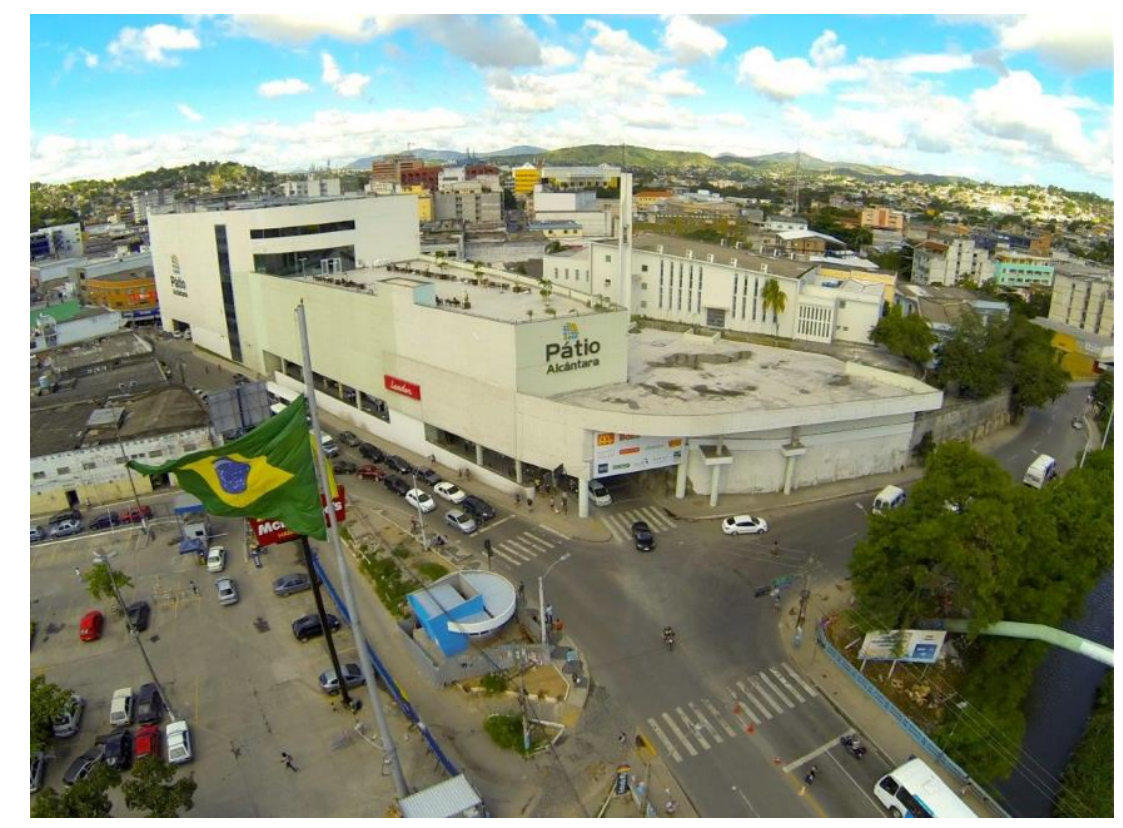

Fonte: Dominus Incorporadora e Construtura

Imagem 31 - Praça Carlos Gianelli, área central de Alcântara (década 1970). O empreendimento Pátio Alcântara foi construído no lugar da antiga praça.

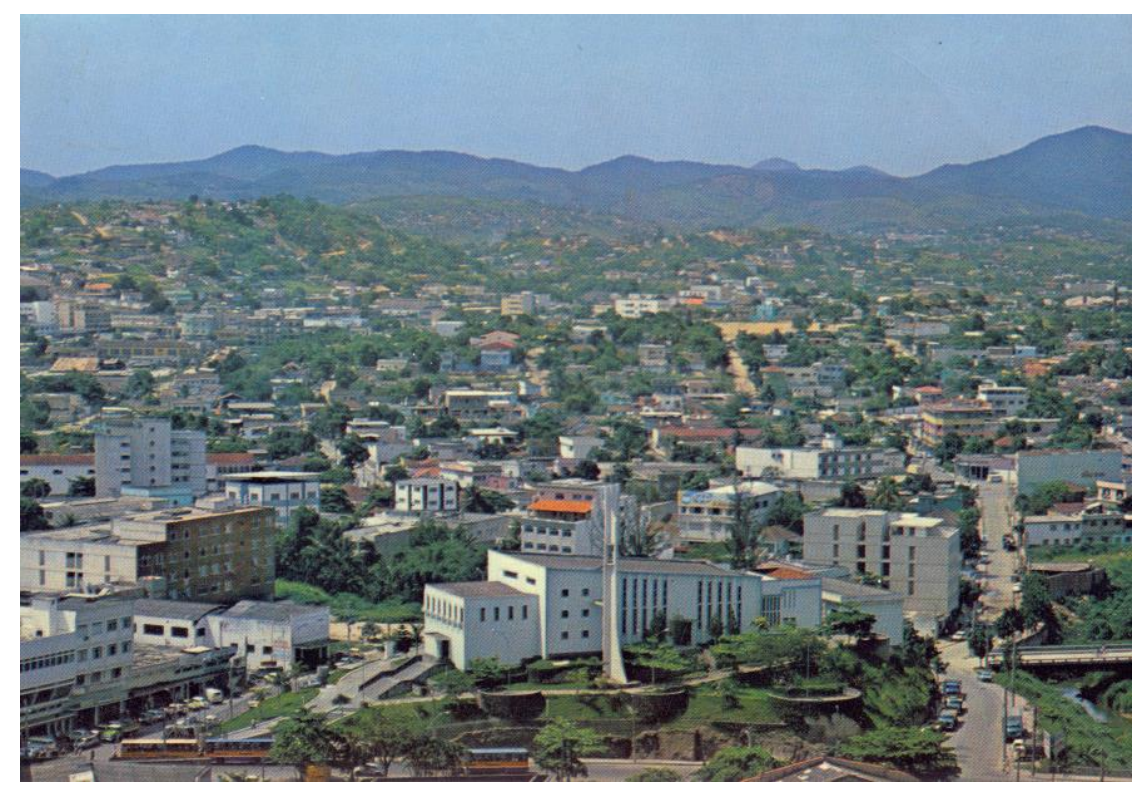

Fonte: Núcleo Gonçalense de Memória, Pesquisa e Promoções Culturais UERJ/FFP. 
Sabemos que as transformações socioespaciais estão articuladas também às transformações políticas e econômicas e explicitam padrões estratégicos de desenvolvimento regional. Atualmente, São Gonçalo busca ganhar destaque no novo contexto produtivo do Estado do Rio de Janeiro, com a indústria petro-gás-química, a retomada da construção naval e com o crescimento da indústria da construção civil. No entanto, se esses ramos somam significativos valores adicionados da indústria ao PIB do estado do Rio de Janeiro, na Metrópole Rio e na Região Metropolitana considerada em termos absolutos, o mesmo não se verifica nos municípios metropolitanos, reconhecidos como centralidades dentre os quais destacamos São Gonçalo e Nova Iguaçu (tabela 10).

É no setor de serviços que o valor adicionado ao PIB resulta em quantias robustas para todos as municipalidades, inclusive para São Gonçalo. O setor de serviços tem uma particular e perigosa importância, pois embora seja responsável pelos maiores números de postos de emprego formal, essa atividade não resolve o problema do vazio produtivo na periferia metropolitana do Rio de Janeiro, como aponta Sobral, pois referem-se a um conjunto de economias locais pouco indutoras e de "segmentos que dependem da circulação de renda existente e que não estão articulados essencialmente ao desenvolvimento de um tecido produtivo e de um sistema logístico" (SOBRAL, 2015a, p. 29). 
Tabela 10 - Produto interno bruto total (bilhões), valor adicionado bruto da indústria e dos serviços (R\$1.000), Estado do Rio de Janeiro, Região Metropolitana do Rio de Janeiro (RMRJ) e alguns municípios metropolitanos

\begin{tabular}{|c|c|c|c|c|c|c|c|c|c|c|c|c|c|c|c|}
\hline \multirow{2}{*}{ UF, RM, Municípios } & \multicolumn{3}{|c|}{1999} & \multicolumn{3}{|c|}{2005} & \multicolumn{3}{|c|}{2010} & \multicolumn{3}{|c|}{2013} & \multicolumn{3}{|c|}{2015} \\
\hline & PIB Total* & $\begin{array}{l}\text { Valor Adic } \\
\text { Indústria }\end{array}$ & $\begin{array}{c}\text { Valor Adic. } \\
\text { Serviços }\end{array}$ & PIB Total* & $\begin{array}{l}\text { Valor Adic. } \\
\text { Indústria }\end{array}$ & $\begin{array}{l}\text { Valor Adic. } \\
\text { Serviços }\end{array}$ & PIB Total* & $\begin{array}{l}\text { Valor Adic. } \\
\text { Indústria }\end{array}$ & $\begin{array}{l}\text { Valor Adic. } \\
\text { Serviços }\end{array}$ & PIB Total* & $\begin{array}{l}\text { Valor Adic. } \\
\text { Indústria }\end{array}$ & $\begin{array}{c}\text { Valor Adic. } \\
\text { Serviços }\end{array}$ & PIB Total* & $\begin{array}{l}\text { Valor Adic. } \\
\text { Indústria }\end{array}$ & $\begin{array}{c}\text { Valor Adic. } \\
\text { Serviços }\end{array}$ \\
\hline RJ & 127,21 & 23,01 & 86,04 & 247,01 & 62,97 & 144,46 & 379,41 & 113,19 & 195,66 & 533,08 & 162,52 & 273,14 & 659,13 & 131,27 & 311,57 \\
\hline RMRJ & 104,00 & 15,18 & 73,07 & 181,70 & 27,24 & 120,94 & 236,60 & 43,43 & 143,61 & 327,45 & 60,74 & 199,11 & 495,00 & 73,00 & 249,32 \\
\hline Rio de Janeiro & 59,20 & 9,85 & 49,32 & 90,51 & 12,65 & 77,81 & 208,15 & 27,47 & 105,83 & 284,30 & 38,20 & 146,07 & 320,77 & 38,48 & 167,60 \\
\hline Duque de Caxias & 6,20 & 1,95 & 4,23 & 19,96 & 8,90 & 11,06 & 16,37 & 6,42 & 9,95 & 15,97 & 1,18 & 14,10 & 35,11 & 8,06 & 16,08 \\
\hline Niterói & 3,93 & 0,47 & 3,45 & 6,07 & 0,89 & 5,17 & 8,79 & 2,08 & 6,71 & 14,75 & 5,04 & 9,69 & 25,72 & 6,92 & 12,86 \\
\hline São Gonçalo & 3,76 & 0,60 & 3,15 & 5,87 & 0,79 & 5,06 & 5,78 & 1,56 & 4,20 & 8,00 & 2,13 & 5,82 & 16,57 & 1,98 & 7,46 \\
\hline Nova Iguaçu & 3,50 & 0,48 & 3,01 & 5,21 & 0,72 & 4,47 & 6,13 & 1,24 & 4,89 & 7,95 & 1,83 & 6,11 & 15,94 & 1,72 & 8,13 \\
\hline
\end{tabular}

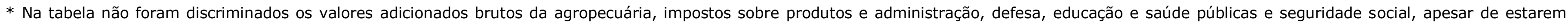
inseridos no valor total do PIB.

Fonte: PIB dos Municípios, IBGE.

Elaboração: Juliana Luquez 
Para o mesmo autor, a consequência dessa baixa densidade produtiva e do fraco dinamismo econômico deve-se ao fato de as atividades serem mais induzidas do que indutoras. Vê-se a problemática urbana estreitar-se à questão regional e ambas formarem os pilares da atual face da crise do Rio de Janeiro, que embora não tenha sido gestada na terceira fase de reestruturação que propomos como instrumento interpretativo da realidade urbana do Rio de Janeiro, forneceu mecanismo de transformações espaciais encobrindo continuidades historicamente reproduzidas.

Vemos que nesse novo contexto de reprodução do capital, a terceira fase do processo de reestruturação em São Gonçalo, os níveis regional e global integram-se e ganham destaque em nossa análise. É pertinente que destaquemos que esses níveis não estão apenas hoje articulados, esses níveis já apresentavam-se como tendências. Na atual fase eles diluem-se um no outro por meio de novas determinações nas relações sociais de produção que passam a operar entre o regional e o global, colocando a análise em uma esfera complexa de dimensões. No nível global, o desenvolvimento do capitalismo transforma a determinação financeira como o seu principal mecanismo de expansão, e no nível regional, o espaço produzido sob esse pretexto se realiza - a reestruturação via setor imobiliário torna-se o álibi da nova conformação do espaço.

A terceira e atual fase de reestruturação do espaço de São Gonçalo caracteriza-se pelo momento de intensificação das funções urbanas complexas nos espaços periféricos da metrópole, nos quais, diferentemente do ritmo e dos interesses que concorreram entre os períodos de 1930-1960 e de 1970-1990, começam a catalisar investimentos públicos e privados a fim de utilizar os territórios metropolitanos em prol da acumulação flexível, não só pelas relações de trabalho, mas especialmente pela relações sociais contidas na produção do espaço. 
As três fases de reestruturação em São Gonçalo nos têm servido de referência metodológica para a compreensão da produção do espaço urbano fluminense na interface com a problemática urbano-regional na qual estão inseridas as cidades e seus processos socioespaciais. A metropolização fluminense assumiu diferentes características, pois são dinâmicos os processos que se inserem no movimento e nos momentos da urbanização que se realiza. Capturar esse movimento e compreender seus momentos é o desafio desse trabalho, para tanto consideramos a tríade forma-função-estrutura como categorias que fundem com os equilíbrios momentâneos e possibilitam a identificação de rupturas e as novas formas de continuidades que reproduzem-se no curso da obra civilizatória da sociedade.

Na periodização que propomos, estaríamos no ponto que chamamos de atual fase crítica. Vimos buscando em Harvey (2013) e Chesnais (1996, 2003, 2005) elementos teóricos que nos auxiliem na compreensão dessa atual fase crítica. Mas é Pereira $(2005,2015)$ vem nos dá subsídios para articular a atual fase com o processo de reestruturação, para o qual a reestruturação dinamiza-se pelo setor imobiliário e encontra especificidade num particular momento de valorização do capital e da propriedade, que tende a funcionar e a existir como capital (PEREIRA, 2006). Essa perspectiva nos leva à necessidade de problematizar a atual estruturação metropolitano-financeira que se impõe sobre a anterior e não como tábula rasa.

A problemática urbana tomou em nossos dias uma direção que vem sendo conduzida pela chave que abre as portas dos empreendimentos imobiliários lançados na base material urbana, o espaço da cidade. A produção de mercadorias no espaço e de espaço-mercadoria está historicamente vinculada às relações sociais de produção, conforme aponta Lefebvre:

O cordão umbilical que ligava a sociedade à natureza foi mal cortado. O que exigia o corte e implicava na ruptura? A cidade. O vínculo se desfez, a troca viva entre a comunidade 
e, no entanto, a sociedade continua ligada e mesmo amarrada à terra. Pela propriedade e pelas múltiplas servidões que ela mantém. Especialmente e sobretudo subordinando a terra ao mercado, fazendo da terra um 'bem' comercializável, dependente do valor de troca e da especulação, não do valor de uso. (LEFEBVRE, 1972; p. 161).

Isto posto, afirmamos que as fases de reestruturação do espaço em São Gonçalo, no contexto da urbanização fluminense, contribuem para a compreensão da realidade metropolitana e revelam as características dos momentos e movimentos contraditórios da realização da sociedade urbana. Passemos agora a elaboração teórica que nos permitiu apresentar cada uma das fases de reestruturação sem as confundir. 


\section{CAPÍTULO 3}

RUPTURAS E CONTINUIDADES: UM PONTO DE VISTA SOBRE A PROBLEMATIZAÇÃO DA REALIDADE URBANA 


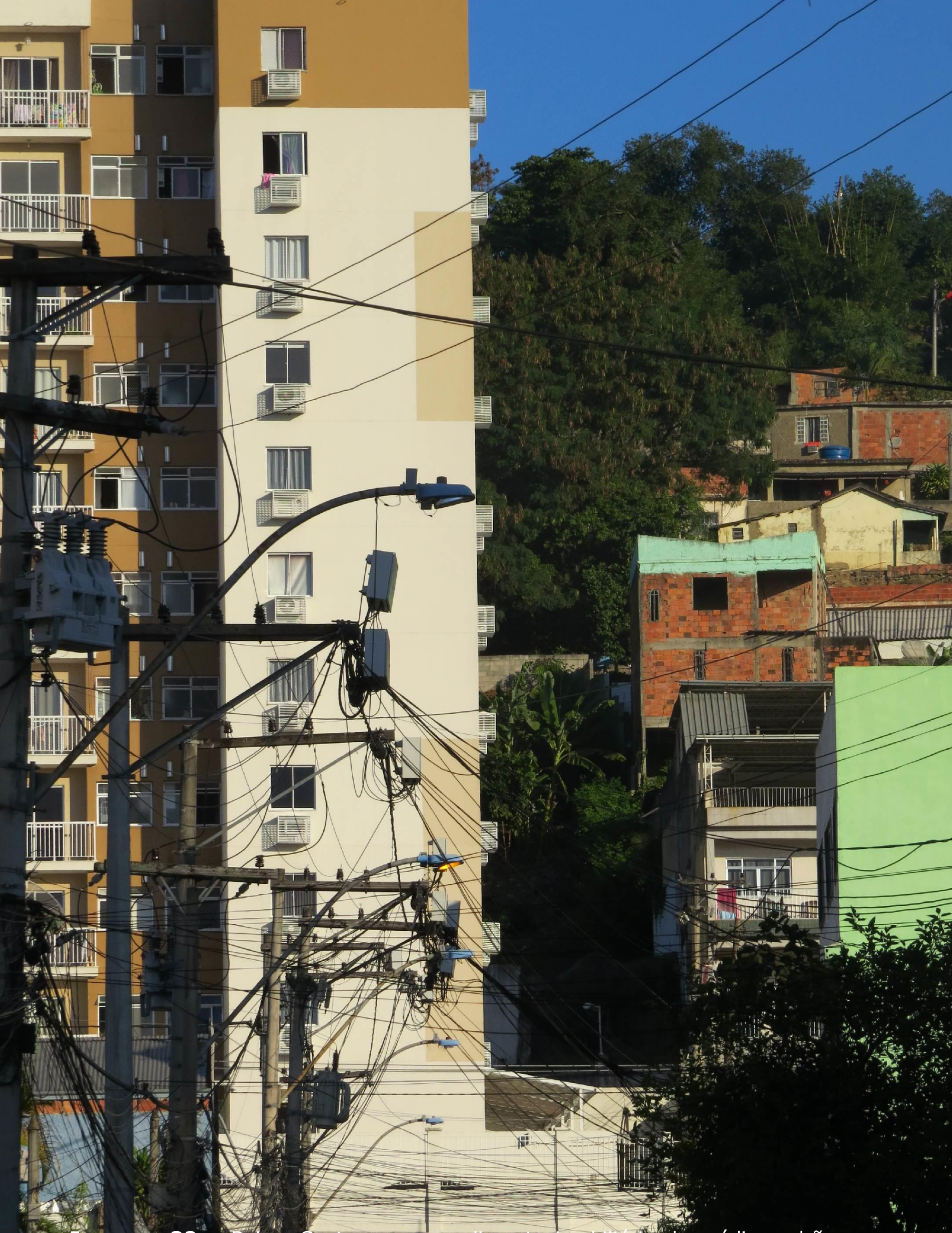

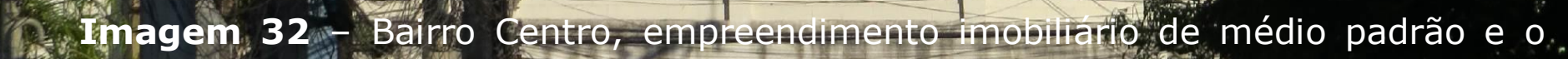
17. Morro Menino Deus ( 2018$)$ \& (Crédito: Julianna Lưuez: 


\subsection{Transformações socioespaciais e princípios interpretativos: o léxico conceitual na compreensão da produção do espaço}

A elaboração teórica que apresentamos nessa seção tem como objetivo discutir a relação contraditória entre as rupturas e as continuidades que articulam os diferentes níveis da realidade urbana. A abordagem que daremos considera que o movimento da produção do espaço pode ser compreendido a partir dessa relação. Para tanto, primeiramente incorporaremos à discussão as reflexões e a análise elaboradas a partir da pesquisa desenvolvida no exterior intitulada "Transformações socioespaciais na aglomeração urbana de Paris: princípios interpretativos e o léxico conceitual na compreensão da produção do espaço"75. Em seguida, nosso propósito cumprir-se-á visando o aprofundamento da compreensão do processo de produção do espaço considerando a simultaneidade e homogeneização da realidade urbana e das concepções teóricas e diferentes respostas interpretativas aos processos urbanos que se manifestam em escala planetária. Esse caminho nos permitiu apresentar cada uma das fases de reestruturação sem as confundir e sem as isolar no tempo ou no espaço, perseguindo um movimento de realização ainda não finalizado.

Antecipamo-nos ao falar que esse movimento compreende momentos de rupturas e de continuidades; estas, por vezes, encobertas nas intensas transformações da realidade urbana, mas em nossa análise, revelando-se através dos processos de periferização, espoliação urbana e segregação socioespacial. Aqui, estes três processos têm igual valor e relacionam-se entre si por meio de relações complexas variadas no contexto da conformação da sociedade urbana em que ora um, ora outro, triunfa sobre a negação de um ou de outro (SCHMID, 2012). Porém, a

75 Transformations socio-spatiales dans l'agglomeration urbaine de Paris: principes interprétatifs et le lexique conceptuel dans la compréhension de la production de l'espace - a bolsa de estágio de pesquisa no exterior (BEPE) foi financiada pela Fundação de Ampara à Pesquisa do Estado de São Paulo (FAPESP) pelo período de 10 meses e supervisionada pelo Professor Paul Claval no âmbito da Université de Paris Sorbonne IV. 
simultaneidade do urbano, faz com que outros tantos processos, ativados aqui ou ali, também concorram para a problematização da realidade urbana. Dessa forma, indagamo-nos: como revelar a simultaneidade da realidade urbana e não a da cidade em si, considerando a cidade uma mediação de cada formação econômico-social? É possível apreender os processos ativados no movimento de produção do espaço considerando rupturas e continuidades da realidade urbana fluminense sem isolar ou dissociar da análise o devir da realidade urbana total?

Além do arcabouço teórico para construir respostas à essas questões, necessitávamos de uma base metodológica que tivesse um potencial explicativo do real sem the escapar o movimento e a totalidade. Encontramos também em Lefebvre um caminho para pensar a tríade estruturação-desestruturação-reestruturação:

[...] a dissolução ou a ruptura dos equilíbrios momentâneos, a desestruturação, não vem após a constituição das estruturas. É em meio aos equilíbrios, no coração das estruturas que atuam desde o início, que se encontram as forças que as dissolverão ou as romperão, que produzirão a desestruturação. [...]. Assim, a desestruturação opera no meio das estruturas, desde seu nascimento, antes mesmo de sua plena e inteira maturação. Jamais as estruturas podem se consolidar e se afirmar. O negativo opera e trabalha no coração do positivo. O possível não é exterior ao real, nem o futuro ao atual: eles já estão presentes e ativos. É o que faz a história. (LEFEBVRE, 1971b; p. 162).

É pelo devir que cremos alcançar uma análise satisfatória da realidade metropolitana fluminense. Perceber que tudo muda e que está mudando parece apenas nos colocar no conforto do formalismo, da observação simples. Qual a natureza de tais transformações? Portanto buscamos nas noções de forma, função e estrutura uma aplicação metodológica para a análise proposta.

As preocupações com os agentes, os processos, as escalas e os desafios da produção do espaço acumulavam-se à medida que desenvolvíamos a análise a partir de São Gonçalo, no contexto metropolitano fluminense. Conforme caminhávamos no tempo e no 
espaço históricos da (re)produção do urbano em São Gonçalo fomos trazidos à reflexão sobre as transformações do presente e as tendências futuras da estrutura metropolitana fluminense e a relação dessas com estruturas urbanas ainda não dissolvidas ou superadas e tão pouco realizadas completamente. Em outras palavras, nossa preocupação também se tornou a análise dos processos de estruturação e reestruturação do espaço metropolitano fluminense na tentativa de compreender dinâmicas metropolitanas e transformações socioespaciais sob a premissa dos movimentos de implosão-explosão, produçãoreprodução.

Desta forma, acreditamos que a análise da reestruturação do espaço de São Gonçalo contribui para aguçar a problemática acerca das dinâmicas de reestruturação da metrópole e de sua região, uma vez que essa análise se deu a partir da identificação das rupturas e transformações da cidade na relação com a reprodução da metrópole. Destacamos que essa pesquisa também consiste em esclarecer o movimento em curso da reestruturação do espaço e ser uma contribuição no uso metodológico de tríades analíticas na investigação da produção do espaço metropolitano.

Por meio da eleição do conceito de reestruturação do espaço, as noções de ruptura e continuidade se impuseram na simultaneidade da realização da urbanização como processo civilizatório e planetário em todas as formações econômico-sociais: as transformações socioespaciais como reveladoras de absorções e superações de momentos pretéritos na sua relação com a realidade da sociedade urbana contemporânea e da maneira como a apreendemos teoria e praticamente. Duas abordagens tornaram-se preponderantes, as características do movimento socioespacial e os conceitos que revelam o seu ritmo.

Essa parte da pesquisa, desenvolvida na Université de ParisSorbonne IV e sob a supervisão do Professor Paul Claval, procurou analisar e discutir os usos e os sentidos dos conceitos que visam expressar as transformações socioespaciais pelas quais a aglomeração urbana de 
Paris vem passando, buscando perceber a abordagem conceitual e a perspectiva metodológica utilizadas nos estudos urbanos franceses que contribuem para a compreensão da realidade contemporânea. Essa realidade, cada vez mais urbanizada, torna-se metropolitana. Cada vez mais espacialmente complexa e conceitualmente obscura em termos explicativos, pois os mesmos conceitos não mais dão conta de representar os diversos processos. Muitas vezes, e cada vez mais, tem-se feito necessária uma tentativa de explicação do real simultaneamente a uma revisão do arcabouço teórico que herdamos sobre os temas cidade e urbano, urbanização e industrialização, produção e reprodução do capital, metrópole e metropolização, etc.

A necessária discussão acerca dos $\operatorname{conceitos}^{76}$ que revelam a natureza e os meandros das transformações socioespaciais constitui-se instrumento analítico da caracterização das fases do processo de reestruturação, tomado como possibilidade também planetária, graças às dinâmicas de acumulação e realização do capital e do espaço que ele produz a partir das relações sociais de produção. Tal aprofundamento teórico contribuiu para uma visão mais ampla das complexidades metropolitanas contidas no objeto de pesquisa da investigação a que se pretende esse trabalho.

O ritmo da urbanização mundial vem acirrando o entendimento de pesquisadores, gestores, políticos, investidores, militantes e cidadãos em geral sobre o tema cidade e urbano. Tema comum a várias áreas do conhecimento e de igual modo tão carente de atualização e constante debate sobre suas possibilidades e limites na prática social. O crescimento acelerado das aglomerações urbanas em vários lugares do globo e a ativação de processos socioespaciais constrangendo estruturas culturais e econômicas aparentemente consolidadas recoloca a todo o tempo o tema

76 De antemão destacamos alguns desses conceitos: périurbanisation, banlieues, périphérie, restructuration ou recompositions socio-spatiales, champs urbains, gentrification, décentralisation, patrimonialisation, ségrégation, requalification des banlieues, rénovation urbaine, justice spatiale, urbanité, etc. 
na agenda de preocupações teóricas dos pesquisadores. Como representantes dessa categoria, interessamo-nos, então, em analisar e discutir essa combinação da abordagem teórica e da perspectiva metodológica para a construção de arcabouços conceituais que buscam esclarecer as transformações socioespaciais no contexto da urbanização como processo histórico e com diferentes ritmos de realização, considerando a realidade fluminense e parisiense.

Vale destacar que não propomos uma aproximação comparativa entre o processo de urbanização no Brasil e na França. Muito pelo contrário, nosso intuito é destacar como esse processo, embora apreendido por uma perspectiva universalista, possui particularidades que caracterizam o fenômeno urbano total. A intenção de analisar e discutir as diferentes concepções teórico-metodológicas que apreendem as transformações socioespaciais em conceitos é, justamente, a de encontrar a simultaneidade da realidade urbana em diferentes contextos.

Para iniciarmos a discussão acerca dos conceitos os quais vêm sendo utilizados para a compreensão das transformações socioespaciais em Paris e na sua aglomeração urbana, partimos da análise crítica do léxico conceitual considerando três termos importantes para a história urbana de Paris: banlieue (subúrbio), périphérie (periferia) e périurbain (periurbano). Esses três conceitos apresentam-se como possibilidade de explicação histórica do movimento de estruturação/reestruturação do espaço urbano da região parisiense. 
Desjardins e Beaurice (2017) iniciam o trabalho intitulado La ville prise aux mots com a seguinte epígrafe:

Fazer a história de uma palavra nunca é perder sua sentença. Breve ou longa, monótona ou variada, a jornada é sempre instrutiva. Mas em toda grande linguagem da cultura existem dez ou mais termos - nunca mais, muitas vezes menos, cujo passado não é um jogo acadêmico. O jogo do historiador, sim, em toda a força da palavra historiador. Esses termos, cujo significado, mais ou menos grosseiramente definido pelos dicionários, continuam a evoluir sob a pressão das experiências humanas, chegam até nós, por assim dizer, ampliados por toda a história pela qual passaram. Apenas, eles permitem seguir e medir com uma precisão bastante lenta (a linguagem não é um aparato de registro muito rápido) as transformações de um grupo dessas ideias-chave que o homem se deleita em acreditar imóvel, porque sua imobilidade parece garantir sua segurança77. (FEBVRE, Lucien et al. apud. DESJARDINS et BEAURICE, 2017).

Nesse trabalho os autores apresentam como propósito de abordagem "a confrontação de textos visa informa os debates que presidem toda a reflexão sobre a cidade e todo projeto para sua transformação78" (DESJARDINS e BEAURICE, 2017, p. 13). Os autores convidam a repensar a questão urbana a partir das qualificações e adjetivações atribuídas ao conceito (ou a noção) de cidade. O interesse dos autores em contribuir no debate teórico do conceito de cidade parece surgir com a percepção de que "nenhum autor (ou quase) se arrisca à

\footnotetext{
77 Texto original: « Faire I'histoire d'un mot, ce n'est jamais perdre sa peine. Bref ou long, monotone ou varié, le voyage est toujours instructif. Mais on compte, dans toute grande langue de culture, une dizaine de termes - jamais plus, souvent moins dont le passé n'est pas du gibier d'érudit. Du gibier d'historien, oui, dans toute la force du mot historien. Ces termes, dont le sens, plus ou moins grossièrement défini par les dictionnaires, ne cesse d'évoluer sous la poussée des expériences humaines, nous arrivent grossis, pour ainsi dire, de toute l'histoire qu'ils ont traversée. Seuls, ils permettent de suivre et de mesurer avec une exactitude un peu lente (le langage n'est pas un appareil enregistreur très rapide) les transformations d'un groupe de ces idées maîtresses que l'homme se complaît à croire immobiles, parce que leur immobilité semble garantir sa sécurité. » (FEBVRE, Lucien et al. apud. DESJARDINS et BEAUCIRE, 2017).

78 Texto original: «la confrontation des textes vise à informer les débats qui président à toute réflexion sur la ville et à tout projet pour sa transformation » (DESJARDINS e BEAUCIRE, 2017, p. 13).
} 
publicar uma obra sobre a cidade sem adicioná-la um atributo ${ }^{79 "}$ (DESJARDINS e BEAURICE, 2017, p. 10).

Essa percepção produziu uma questão a ser analisada pelos autores: "da cidade à cidade sem qualidades à cidade cercada de atributos, o que aconteceu?"80 (DESJARDINS e BEAURICE, 2017, p. 11). Para responder a essa questão os autores recorrem às pesquisas no domínio da geografia e da sociologia desde o final do século XIX até os dias atuais, identificando algumas rupturas importantes no tempo e no espaço acerca do pensamento sobre a cidade: os anos 1920, o período entre-guerras, os anos 1960, os anos 1990, e os trabalhos das duas primeiras décadas do século XXI.

A contribuição de Desjardins e Beaurice, nos coloca em diálogo não só com a literatura internacional sobre a cidade, o pensamento sobre a cidade e suas transformações, como também nos aproxima da obra do geógrafo francês Burgel que, segundo os autores

A cidade tomada por palavras faz eco ao capítulo que Guy Burgel dedicou a um século de pensamento geográfico sobre a cidade nos Ensaios Críticos da Cidade, onde, em uma seção dedicada às palavras e abordagens da cidade, a maneira pela qual a ciência os grupos sociais abordam o conceito de cidade, ele observa "certamente que a cidade é sempre mais rica do que as palavras que a definem, as explicações que a descrevem, os planos que a projetam" (DESJARDINS e BEAURICE, 2017, p. 12 - grifos dos autores). ${ }^{81}$

Em Burgel percebemos que com a elucidação das adjetivações e possibilidades metodológicas de apreensão das transformações da cidade,

\footnotetext{
79 Texto original: «pas un auteur (ou presque) ne se risque (plus) à publier un ouvrage sur la ville sans l'assortir d'un qualificatif ». (DESJARDINS e BEAUCIRE, 2017, p. 10).

80 Texto original: «de la ville à la ville sans qualités jusqu'à la ville assiégée de qualificatifs, que s'est-il passé? » (DESJARDINS e BEAUCIRE, 2017, p. 11).

${ }^{81}$ Texto original: La ville prise aux mots fait écho au chapitre que Guy Burgel a consacré à un siècle de pensée géographique sur la ville dans le Essais critiques sur la ville où, reprenant dans une partie consacrée aux mots et aux approches de la ville la façon dont les sciences sociales abordent le concept de ville, il relève « certainement que la ville est toujours plus riche que les mots qui la définissent, les explications qui la décrivent, les plans qui la projettent »(DESJARDINS e BEAUCIRE, 2017, p. 12 - grifos dos autores).
} 
"nós esperamos ir da definição da cidade para a do urbano"82 (BURGEL, 2015, p. 39). Dizendo de outra forma, as rupturas e continuidades tomadas em conceitos como um ponto de vista da problematização da realidade urbana contribuem muito mais para fornecer categorias de análise muito mais do que critérios de definição. Em contato com a obra de Burgel encontramos a mesma preocupação teórica que moveu os objetivos da parte dessa pesquisa desenvolvida no seio do laboratório Espace, Nature et Culture (ENEC), vinculado ao Institut de Géographie da Université de Paris-Sorbonne IV, qual seja: analisar e discutir os usos e os sentidos dos conceitos tomados como princípios interpretativos para expressar as transformações socioespaciais pelas quais a cidade e a aglomeração urbana de Paris vêm passando, considerando-os como pistas para a apreensão de rupturas e continuidades na compreensão da produção do espaço como processo histórico universal e em realização.

Dessa forma, compreendendo como movimento do real, nossa abordagem metodológica buscou evidenciar, a partir dos conceitos e noções, os momentos de realização da sociedade. As rupturas e as continuidades, ou seja, os desequilíbrios momentâneos e a gênese da reprodução das contradições constituem-se nos maiores desafios interpretativos no seio das relações sociais de produção contidas no espaço que as realiza e as quais reagem sobre sua própria produção. É perceptível que, sendo o processo de urbanização um fenômeno histórico e em plena realização, seu movimento seja marcado por fases de estruturação-desestruturação-reestruturação do espaço. Eis o ponto chave dessa seção: problematizar a realidade urbana contemporânea a partir da compreensão desse movimento (estruturação-desestruturaçãoreestruturação), quer na França, no Brasil ou em outros territórios da mundialização do urbano.

A discussão aqui apresentada é parte de um movimento do pensamento sobre a realidade urbana contemporânea, tendo como 82 Texto original: « espère-t-on passer de la définition de la ville à celle de l'urbain » (BURGEL, 2015, p. 39). 
quadros analíticos distintos e relacionais, as aglomerações urbanas fluminense e parisiense. Reservamos para essa seção os resultados da pesquisa que considerou analisar as transformações socioespaciais em Paris e sua aglomeração urbana a partir do léxico conceitual (conceitos/noções) e dos princípios interpretativos utilizados na compreensão da produção do espaço, buscando um paralelo teóricometodológico com os capítulos anteriores, os quais privilegiamos as transformações socioespaciais na aglomeração urbana do Rio de Janeiro, tendo como ponto de partida a cidade de São Gonçalo.

Entre os conceitos e noções mais utilizados na literatura francesa sobre os estudos urbanos destacamos aqueles que consideramos essenciais para a compreensão da produção do espaço na perspectiva do movimento da realização da sociedade urbana. Porém, é importante frisar a linha tênue entre a definição de um termo e sua abordagem no campo da pesquisa acadêmica e no campo da execução política de projetos urbanísticos (quer de natureza econômica, cultural ou urbana):

- Périurbain, périurbanisation (BERGER, 2004; STEINBERG, 2016; DONZELOT e MONGIN, 2013)

- Banlieues (DEMANGEON, 1933; SOULIGNAC, 1993; BERTHO, 1997; GIBLIN et al, 2009; BOYER, 2000; VIEILLARD-BARON, 1996, 2011a)

- Restructuration des banlieues et périphérie (ALBECKER, 2014; 2015)

- Métropolisation (CLAVAL, 1989; 2005)

- Champs urbains (CLAVAL, 1981)

- Métropole régionales, métropole d'équilibre (HAUTREUX e ROCHEFORT, 1965)

- Villes nouvelles (MERLIN, 1991)

- Recomposition ou restructurations territoriales (IAU-IdF, 2014) 
- Grand Paris (CARMONA, 1979; BASTIÉ, 1984; SUBRA, 2009; BÉHAR, 2009; DESJARDINS, 2010 e 2016)

- Mixité sociale, ségrégation, gentrification (FIORAVANTI, 2015; DONZELOT, 2006 e 2009)

- Rénovation urbaine (EPSTEIN, 2013)

- Désindustrialisation et friche industrielle (EDELBLUTTE, 2011)

- Patrimonialisation, requalification et renouvellement urbaine, réhabilitation urbaine (FOL e RAAD, 2014; GRAVARI-BARBAS et al, 2015)

Esses conceitos e noções apreendem tanto a forma, a estrutura e a função nas quais o espaço se revela como produto, meio e condição de realização da sociedade em seu movimento histórico. Ao longo de toda a discussão percorreremos três problemáticas importantes para o desenvolvimento dos argumentos aqui apresentados, a saber:

- Considerando o movimento "destruição/construção" em Paris e em sua aglomeração urbana, quais são os princípios de interpretação para a compreensão das transformações socioespaciais?

- Quais são as características e especificidades gerais das aglomerações parisiense e fluminense dada a transição da estrutura urbano-industrial para a estrutura metropolitana-financeira?

- Se o espaço é estruturado e reestruturado em favor da fragmentação, da homogeneização e da hierarquização, quais outras tríades analíticas nos permitem vislumbrar o movimento do processo de reestruturação do espaço como um álibi para a reprodução do capital?

Buscamos na literatura referências ainda dos anos 1930, como o clássico estudo de Demangeon sobre a estruturação da cidade de Paris e de seus subúrbios (DEMANGEON, 1933). Percorremos através do trabalho de Jacqueline Beaujeu-Garnier et Jean Bastié as características da 
aglomeração urbana de Paris em 400 páginas de descrição, análise de dados, referências conceituais e bibliográficas sobre as etapas de expansão espacial da região parisiense: "os caminhos de ferro, os loteamentos, os grandes conjuntos habitacionais e a predominância dos meios de transporte"83 (BEAUJEU-GARNIER; BASTIÉ, 1967, p. 61).

Nas pesquisas de Michel Rochefort e Jean Hautreux, principalmente no trabalho de 1965 sobre a estrutura urbana francesa, encontramos a dimensão regional na análise das interfaces entre as atividades econômicas e as aglomerações urbanas na França. A noção de metrópoles regionais, posteriormente chamadas de metrópoles de equilíbrio, surge da contribuição das pesquisas desses autores.

Os anos 1970 e 1980 são marcados pelos estudos em torno da expansão da urbanização, renovando o debate dicotômico entre cidade e campo, urbano e rural. Na França, as estratégias de ação dos diferentes atores de produção do espaço e planificação do território encontram-se no eixo central dos temas de pesquisa, que incluíam, por exemplo, a avaliação dos propósitos e da implantação de projetos de desenvolvimento territorial, a análise das políticas de descentralização urbana na região parisiense, etc.

O volume de trabalhos produzidos sobre a temática urbana compreendia também relatórios e dossiês de equipes de pesquisadores responsáveis não só pela problematização teórica das reflexões como também por propor soluções espaciais para as questões urbanas falamos no que se refere à França, mas esse movimento também pode ser verificado no Brasil na mesma época. Os exemplos mais emblemáticos que estacamos são:

- Grand Paris: embora seja um projeto que tem suas origens no império de Napoleão III (1860), é a partir de 1961, com a criação

\footnotetext{
83 Texto original: «les chemins de fer, les lotissements, les grands ensembles e la prédominance de l'influence des moyens de transports » (BEAUJEU-GARNIER; BASTIE, 1967, p. 61).
} 
do District de la Région de Paris que o projeto ganha envergadura, inclusive legal, como instrumento de planificação, destacando-se como elemento estruturante nas políticas de desenvolvimento territorial da Metrópole Paris. Atualmente, dentre os objetivos do projeto, destacam-se o planejamento do espaço metropolitano, o desenvolvimento econômico, a preservação ambiental e a promoção de habitação local, considerando a área das communes (cidades) que compõem o Grand Paris ${ }^{84}$. O Grand Paris parece possuir uma hibridez característica dos projetos de políticas e operações urbanas realizados pelos atores governamentais, em benefício dos interesses econômicos: articular sempre a periferia à metrópole enquanto amplia a periferia da metropolização. (GEO, 1991)

- Banlieues 89: projeto lançado em 1983 e liderado pelo arquiteto Roland Castro, reunia políticas e estratégias de ações urbanísticas para melhorar as condições de vida nos subúrbios parisienses, sob o contexto do Grand Paris. Segundo um dossiê publicado em 1985, o projeto visava "reestruturar o espaço na periferia"85 (CASTRO; CANTAL-DUPART, 1985).

Ascher, em seu livro Les nouveaux príncipes de l'urbanisme, la fin des villes n'est pas à l'ordre du jour (2001), o autor buscou abordar as transformações socioespaciais considerando a relação entre as estruturas que articulam as cidades e as sociedades modernas e os tipos de urbanismo que se engendram em cada fase daquilo que o autor chama de revoluções urbanas. Para Ascher, as mutações da sociedade moderna implicaram em mudanças importantes no que diz respeito à concepção, produção e gestão das cidades e territórios, e essas mudanças "colocam na agenda uma nova revolução urbana moderna, a terceira após a da

\footnotetext{
${ }^{84}$ Uma metrópole, 12 territórios e 131 cidades, de acordo com o site oficial do projeto: <http://www.metropolegrandparis.fr/fr/content/carte-des-territoires>.

85 Texto original: "restructurer I'espace en périphérie" (CASTRO e CANTAL-DUPART, 1985).
} 
cidade clássica e a da vila industrial"86 (ASCHER, 2001, p. 6). O horizonte que o autor nos aponta é o de que a cidade é, definitivamente, a forma espacial mais importante para a sociedade moderna e sua fase atual; entretanto, é preciso ir além da cidade enquanto forma, é necessário decodificar os instrumentos novos e os princípios sob os quais a cidade e a sociedade se modifica.

Assim como os trabalhos de Ascher (1995, 2001, 2009), a literatura datada a partir dos anos 1990 mostra-se incessante na busca pela compreensão do movimento das transformações socioespaciais muito mais do que das transformações em si. Em outras palavras, percebemos que as análises realizadas em torno dos estudos urbanos vêm buscando a problematização da sociedade urbana e não da cidade em si, pois a cidade só existe porque as relações sociais a produzem, a mantém e a transformam.

Isso pode ser ilustrado no trabalho de Vieillard-Baron (2011) sobre as transformações na região industrial do norte de Paris, intitulado $L a$ Plaine Saint-Denis: un ancien territoire industriel au centre des contradictions métropolitaines. Em algumas páginas, o autor percorre 100 anos de industrialização, 40 anos de desindustrialização e os últimos quase 20 anos de produção imobiliária (tanto de escritórios quanto de habitação). Esse percurso pelas continuidades e rupturas reforça nossa expectativa de compreender as transformações socioespaciais na perspectiva do movimento da produção do espaço.

Esse movimento da produção do espaço no contexto da metropolização pode ser compreendido, em nossa interpretação de Ascher (2009), a partir da tríade expansão-fragmentação-recomposição ${ }^{87}$. Para o autor, mesmo que a metropolização possua formas variadas, de acordo com a história da urbanização de cada país ou região, a densidade

\footnotetext{
${ }^{86}$ Texto original : « mettent à l'ordre du jour une nouvelle révolution urbaine moderne, la troisième après celle de la ville classique et celle de la villa insdustrielle »(ASCHER, 2001, p. 6).

87 Texto original: «étalement-fragmentation-recomposition ».
} 
urbana, o sistema cultural e as políticas territoriais adotadas, ela também apresenta uma tendência global

[...] formar unidades territoriais, maiores e mais povoadas, que constituem o novo marco das práticas cotidianas ou habituais dos habitantes e das empresas. Os moradores dessas áreas urbanas vivem e trabalham cada vez menos na escala de um bairro ou cidade, mas na de um vasto território, que eles percorrem de maneiras diversas, por razões profissionais ou não. ${ }^{88}$ (ASCHER 2009, 268).

Sobre esse fenômeno na França, o autor destaque que

[...] a metropolização não se manifestou recentemente; foi sendo mascarada estatisticamente por algum tempo pela "rurbanização", as aldeias periurbanas fora de aglomerações inchadas com populações que não tinham nada rural ${ }^{89}$ (ASCHER 2009, 268).

Na França, e especialmente em Paris, nossa análise demandou um mergulho não nas transformações socioespaciais em si mesmas, mas na compreensão dessas a partir das noções e conceitos que as apreendem. Isso porque ao questionar a modernidade como ruptura nas reformas urbanas do Barão de Haussmann na Paris do século XIX, David Harvey, nos sugere que a maior ruptura do período Haussmanniano pode não ser as edificações e os projetos urbanísticos, e sim a escala de suas implantações e ambições espaciais. Para Harvey, essa postura planificadora permitiu pensar a cidade e seus subúrbios como uma totalidade (HARVEY, 2015). Nesse sentido, o projeto de Haussmann não visava conter um movimento característico da cidade moderna, o de implosão-explosão ou demolição/reconstrução, ele o produziria ou o facilitaria tecnicamente.

88 Texto original: « [...] former des ensembles territoriaux, plus vastes et plus peuplés, qui constituent le nouveau cadre des pratiques quotidiennes ou habituelles des habitants et des entreprises. Les résidents de ces zones urbaines vivent et fonctionnent en effet de moins en moins à l'échelle d'un quartier ou d'une ville, mais à celle d'un vaste territoire, qu'ils parcourent de façons variées et changeantes pour toutes sortes de motifs professionnels et non professionnels. 》 (ASCHER, 2009, p. 268).

89 Texto original: [...] la métropolisation n'est devenue manifeste qu'assez récemment ; elle a d'ailleurs été masquée statistiquement quelque temps par la « rurbanisation », les villages périurbains hors des agglomérations se gonflant de populations qui n'avaient en fait plus rien de rural. (ASCHER, 2009, p. 268). 
Nessa análise regressiva da estruturação urbana de Paris vimos a necessidade de apresentar algumas reflexões sobre a aglomeração urbana parisiense examinando as noções de banlieue, périphérie e périubain, visto que essas noções ou conceitos revelam o movimento e a espacialidade do fenômeno urbano a partir de Paris e em direção aos territórios que formariam, um século depois, os domínios da metropolização.

3.1.1. Entre les banlieues, périphéries et périurbains parisiens: aspectos teóricos e conceituais na compreensão das transformações socioespaciais da aglomeração urbana de Paris

A levantamento do léxico conceitual utilizado na literatura dos estudos urbanos na França nos levou imediatamente ao necessário reconhecimento das diferentes formas urbanas justapostas no tempo e no espaço de conformação (e recomposição) da aglomeração urbana de Paris. Os trabalhos de campo realizados durante a pesquisa - e descritos no Apêndice deste capítulo - nortearam nossa análise empírica e contribuíram para a apropriação teórica dos conceitos utilizados na compreensão dos processos socioespaciais em curso na urbanização francesa.

As dinâmicas espaciais da aglomeração urbana parisiense fazem sobressair a Metrópole Paris na sua relação com os territórios da urbanização. E nesses territórios manifestam-se formas, funções e estruturas urbanas que revelam as continuidades, as rupturas e os ritmos das transformações socioespaciais.

Interessados em compreender tais continuidades, rupturas e ritmos numa perspectiva ainda mais sensível, recorremos à exposição Peindre la banlieue (imagem 33) promovida pelo Musée Français de la Carte à Jouer, localizado em Issy-les-Moulineaux, commune da petite couronne de 
Paris $^{90}$. Um percurso de 100 anos (1850-1950) pelos subúrbios e periurbanos de Paris através da arte impressionista nos revelara a simultaneidade da tríade forma-função-estrutura na compreensão do fenômeno urbano na região parisiense.

Na tela de Paul Cézanne (1872-73) pode-se vislumbrar, entre o bucólico e a via, a força da representação dos subúrbios de Paris no final do século XIX: as estradas de ferro que comunicam os subúrbios à cidade, as estradas vicinais que comunicam as vilas e povoados às estações. $O$ bucólico se apresenta nas formas de habitar e faz-nos confusos entre o domínio do rural face aos caminhos para o urbano. Na tela de Claude Monet (1872), a fumaça que se confunde com as nuvens de um dia nublado na commune de Argenteuil, parece representar esse importante elemento estruturante do espaço, as estradas de ferro. A urbanização na região parisiense não só irá acompanhar os trilhos dessa fumaça, como a ela se misturar.

\footnotetext{
90 A aglomeração urbana de Paris compreende três arranjos territoriais. A Paris intramuros, que se refere aos limites administrativos da cidade de Paris, no passado definido pelos muros que cercavam a cidade estruturada, atualmente definidos pelo anel viário Boulevard Périphérique. A petite couronne e a grande couronne. A primeira compreende 123 communes e constitui-se em uma zona de três departamentos administrativos limítrofes à Paris: Hauts-de-Seine, Seine-Saint-Denis e Val-de-Marne. Essa área também possui como característica histórica do o fato de que a administração de várias municipalidades era exercida pelo Partido Comunista Francês. A banlieue rouge, consolidada em 1930, vive, desde então, consecutivas e significativas perdas do poder da esquerda e, simultaneamente, uma recomposição da base social clássica para um "novo proletariado", constituindo-se numa "réalité urbaine et un phénoméne géopolitique" (Giblin et al, 2009, p. 92). A grande couronne, compreende departamentos administrativos periféricos da Região da Île-de-France limítrofes à petite couronne, quais sejam: Seine-et-Marne, Yvelines, Essonne e Val-d'Oise (BRÈS e SANJUAN, 2011).
} 
Imagem 33 - Alguns aspectos e transformações socioespaciais da banlieue parisiense nas telas de pintores impressionistas

Paul

\section{CEZANNE}

$(1839-1906)$

Route de

village à

Auvers, vers

$1872-1873$

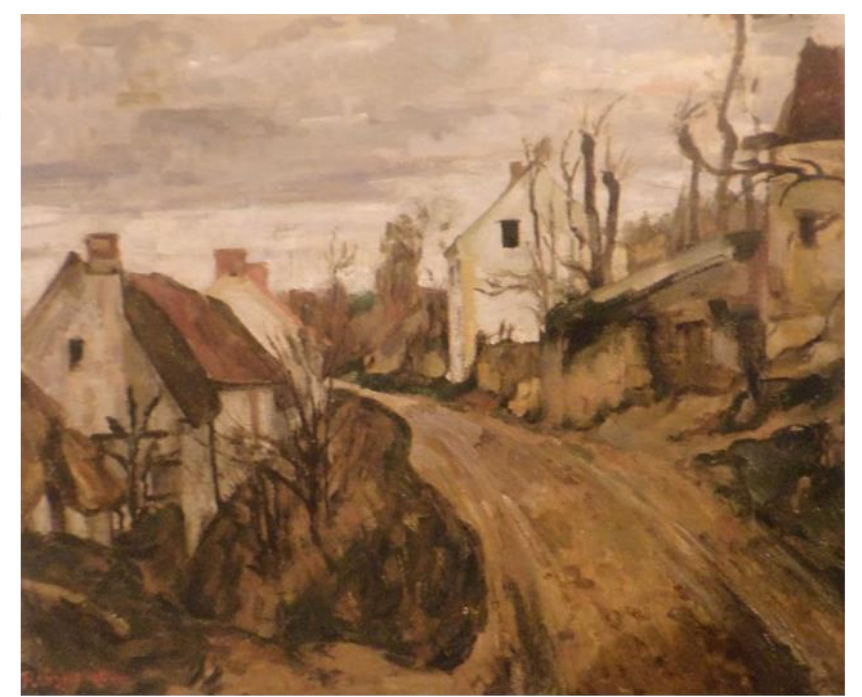

Paul

SIGNAC

(1863-1935)

Les dix-huit

chemisées

de Saint-

Denis, 1933
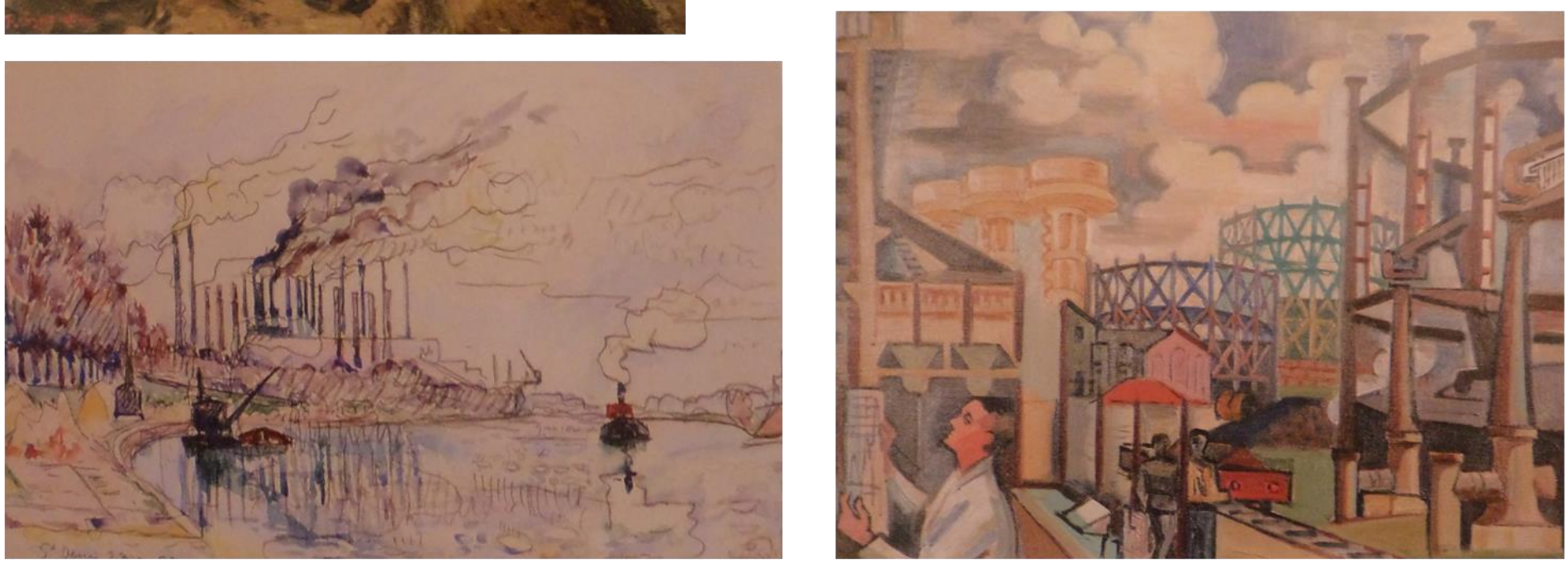

Claude

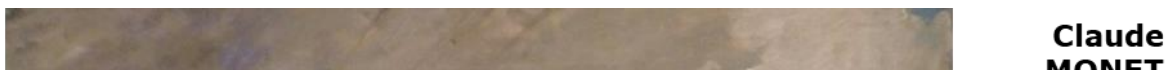
(1840-1926)

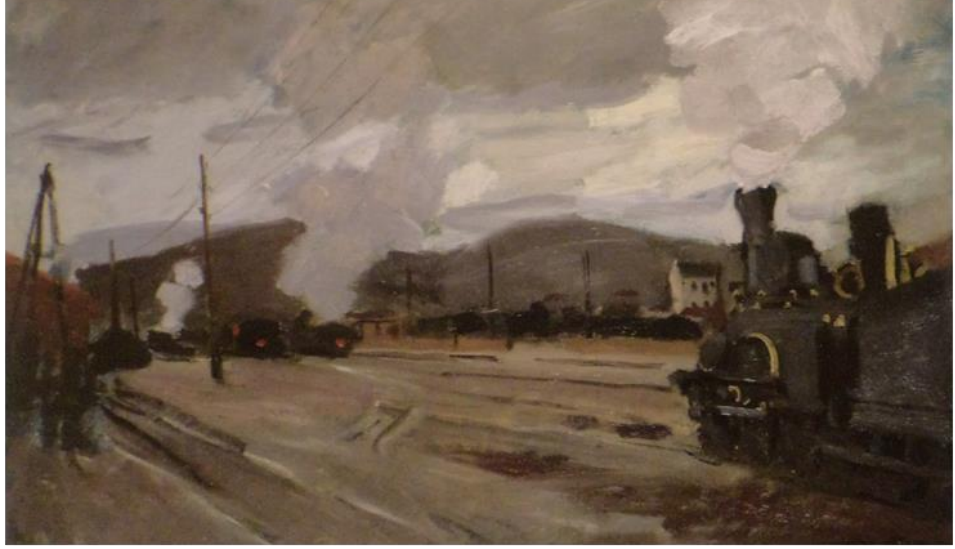

Gare

1872

Fonte: Musée Français de la Carte à Jouer. Peindre la banlieue, de Cornot à Vlaminck (1850-1950), catálogo (2017). 
A escolha de Paul Signac (1933) pela aquarela para representar as 18 chaminés da Société d'Électricité de Paris às margens do Rio Sena em Saint-Denis, nos permite perceber as formas cada vez mais rígidas e racionais que as transformações da sociedade moderna imprimem sob o espaço. Finalmente, na tela de André Lhote (1937), destaca-se uma personagem que passa a representar a banlieue parisiense até meados do século XX: o operário. A figura do operário e suas relações sociais no contexto da vida moderna, urbana e industrial, permite-nos compreender as dimensões das transformações profundas que marcaram o processo de urbanização na França e no mundo depois dos anos 1950 (MARICONIEBRARD, 1993).

A partir dos trabalhos de Boyer (2000), Soulignac (1993), Bertho (1997), Vieillard-Baron (1997; 2011a), Berger (2004), Giblin (et al, 2009), Donzelot (2004; 2006), dentre outros autores, mergulhamos nas problemáticas teóricas e nas investigações empíricas da aglomeração urbana parisiense entre banlieues, périphéries et périurbains.

De acordo com Vieillard-Baron, as primeiras definições de banlieue estão estreitamente ligadas à recursos institucionais e jurídicos da cidade na Idade Média. Entre os séculos XVII e o final do século XVIII, a banlieue conhece seu destino de transformações. Já consolidada como termo jurídico e histórico - no que se refere ao em torno de cidades das quais a banlieue dependesse (VIEILLARD-BARON, 1997). Segundo o autor, é no século XIX que a banlieue insere-se na dinâmica socioespacial francesa

O uso da palavra é transformado sob a Restauração. Os subúrbios começam então a fazer parte de um sistema de valores que opõe Paris à província e, mais geralmente, à cidade contra tudo o que a rodeia. A palavra é responsável por apreciações qualitativas. Os princípios da hierarquia urbana e divisão social do espaço tornam-se mais claros. ${ }^{91}$ (VIEILLARD-BARON, 1997, p.13).

\footnotetext{
91 Texto original: «L'usage du mot se transforme sous la Restauration. La banlieue commence alors à s'inscrire dans un système de valeurs qui opposent Paris à la province, et, plus généralement, la ville à tout ce qui l'entoure. Le mot se charge d'appréciations qualitatives. Les principes de hiérarchie urbaine et de division sociale de l'espace se
} 
A partir de Vieillard-Baron, podemos concluir que a divisão social do espaço é uma característica marcante do processo de urbanização da aglomeração urbana de Paris e que vai acompanhar todas as transformações socioespaciais futuras. Para o autor é nesse momento que o termo banlieue ganha o sentido de periferia urbana dependente, e dessa forma, a compreensão de sua relação com a cidade e com o fenômeno urbano também se modificam.

Em dois séculos, os subúrbios perderam seu significado legal para tomar o sentido da periferia urbana dependente. Os subúrbios contemporâneos nasceram do aumento demográfico, do êxodo rural e especialmente da revolução industrial, com a evolução dos meios de transporte. Depois da estrada, a ferrovia traça as direções da urbanização. A partir do século XIX, Paris retorna aos subúrbios, a população que não pode mais acomodar, mas menos sistematicamente do que se costuma acreditar; e o campo envia os homens que não pode mais se alimentar para as grandes cidades. O subúrbio de Paris, que é o único reconhecido na época, tornou-se uma saída para atividades volumosas e poluentes: pedreiras fornecimento de materiais necessários para a construção ou obras em estradas (gesso, areia, argila, pedra silhar), locais militares, grandes oficinas, estações de triagem, reservatórios de água, estações de tratamento de esgoto, usinas a gás, usinas elétricas, aterros sanitários, etc. Muitos serviços relacionados à saúde e lazer lá se estabeleceram: hospitais psiquiátricos, asilos, lares de idosos, campos desportivos, hipódromos. Os cemitérios parisienses "fora dos muros" se desenvolvem sucessivamente: Ivry Bagneux, Saint-Ouen, Pantin-Bobigny, por exemplo. As formas de dependência que ligam a cidade ao espaço circundante estão em constante crescimento. (VIEILLARD-BARON, 1997, p.21) ${ }^{92}$.

précisent. » (VIEILLARD-BARON, 1997, p. 13)

92 Texto original: «En deux siècles, la banlieue a donc perdu son acception juridique pour prendre le sens de périphérie urbaine dépendante. La banlieue contemporaine est née de l'augmentation démographique, de l'exode rural et surtout de la révolution industrielle, avec l'évolution des moyens de transport. Après la route, le chemin de fer trace les directions de I'urbanisation. A partir du XIXe siècle, Paris renvoie vers la banlieue la population qu'elle ne peut plus loger, mais moins systématiquement qu'on ne le croit souvent; et la campagne envoie les hommes qu'elle ne peut plus nourrir vers les grandes agglomérations. La banlieue parisienne, parisienne, qui est la seule reconnue à l'époque, devient un exutoire pour les activités encombrantes et polluantes : carrières fournissant les matériaux nécessaires à la construction ou à la voirie (gypse, sable, argile, pierres de taille...), terrains militaires, gros ateliers, gares de triage, réservoirs d'eau, stations d'épuration, usines à gaz, centrales électriques, décharges, etc. De nombreux services liés à la santé et aux loisirs s'y installent : hôpitaux psychiatriques, 
A conformação e as sucessivas transformações do espace banlieusard de Paris, podem ser também apreendidas segundo três definições que consideram o contexto histórico das transformações da própria sociedade francesa. Segundo Boyer, as definições seriam: a) banlieue como instrumento jurídico e administrativo dos territórios durante a Idade Média, b) a partir do século XIX, considera-se a banlieue como a área da urbanização que se estende para fora dos limites de Paris (ou no caso de outras importantes cidades da França, como Lyon, Toulouse, Lille e Boudoux), c) mais recentemente, nos anos 1980, a banlieue é resignificada a partir de características sociais, que transformam-a em um mosaico da estrutura socioeconômica da França (BOYER, 2000, p. 9-20).

Boyer propõe compreender a banlieue francesa e parisiense a partir de uma tríade que permeia a noção do termo e carrega suas transformações históricas, qual seja: do jurídico ao espacial ao social ${ }^{93}$ (BOYER, 2000, p. 9). Para o autor as transformações ocorridas entre o século XIX o a segunda metade do século $X X$ possuem uma dimensão espacial muito nítida, enquanto que as transformações dos últimos 30 anos adquiriram um componente social que levou a banlieue a uma "irruption du social" - o autor refere-se a dois marcos importantes da chamada Crise des Banlieues, conhecidos como Été 1981 e Émeutes de I'automne 2005; sua gênese pode ser encontrada, segundo Boyer (2000) e Bertho (1997), nas mudanças e intervenções políticas iniciadas nos anos 1980, onde as ações do Estado pareciam apresentar uma sutileza entre a política urbana e a politique de la ville, reforçando tensões e evidenciando atores e interesses.

Através do trabalho organizado por Giblin (2009) nossa compreensão sobre a organização e as transformações socioespaciais da

hospices, maisons de repos, terrains de sport, hippodromes... Des cimetières parisiens « hors les murs » s'y développent successivement : à Ivry, Bagneux, Saint-Ouen, PantinBobigny par exemple. Les formes de dépendance liant la ville à l'espace qui l'entoure ne cessent de s'amplifier. » (VIEILLARD-BARON, 1997, p. 21).

93 Texto original : «du juridique au spatial au social » (BOYER, 2000, p. 9). 
banlieue parisiense encontra a dimensão teórica a qual vimos prosseguindo: a problemática urbana pode ser compreendida a partir do movimento de estruturação-desestruturação-reestruturação, e no caso de Paris, esse movimento materializa-se entre les banlieues, périphéries et périurbains. Para Giblin essa porção do espaço apresenta várias características demasiadamente sobressalente da estrutura social parisiense e de sua dimensão espacial, como por exemplo

[...] alta densidade populacional, concentração de população estrangeira, alta proporção de menores de 25 anos, alta taxa de desemprego, taxa de inadimplência bem acima da média nacional, situação local onde a tensão entre diferentes grupos sociais é perceptível. ${ }^{94}$ (GIBLIN et al, 2009, p. 9).

A perspectiva teórica e a abordagem metodológica dos trabalhos e pesquisas sobre a aglomeração urbana parisiense nos aproximam de uma inferência: a recomposição social produziu um espaço de desigualdade e transformou a problemática urbana em um desafio quase insuperável, no qual a periferização aparece muito mais com uma lógica de segregação do que como um processo inevitável do desenvolvimento desigual - e é, justamente, pela primeira que se torna o segundo.

Através da obra do sociólogo Donzelot, construímos uma compreensão crítica sobre a aglomeração urbana de Paris, especialmente no que se refere aos domínios de sua banlieue e seu périurbain. Donzelot (2004), diferentemente de Boyer (2000), defende que a questão social, que expressa-se na violência, na delinquência juvenil, na alta taxa de desemprego entre os jovens, não é o fundamento da problemática urbana que envolve os espaços periféricos de Paris. Para Donzelot

Outros, incluindo nós mesmos, preferem falar de uma questão urbana, portanto de um questionamento da cidade, das tendências que inspiram sua configuração e as transformações desta. [...] Nós estamos vivendo sempre o mesmo problema: o da conflitualidade das relações sociais

94 Texto original: «[...] forte densité de population, concentration de population étrangère, forte proportion de moins de 25 ans, taux de chômage élevé, taux de délinquance nettement supérieur à la moyenne nationale, situation locale où la tension entre les différents groupes sociaux est perceptible. » (GIBLIN et al, 2009, p. 9) 
de produção, da insuficiente proteção das classes trabalhadoras $^{95}$. (DONZELOT, 2006, p. 34).

O autor argumenta que tratar a questão social como fundamento dos problemas da banlieue em detrimento da questão urbana é o como considerar o urbano um reflexo do social e, assim, "uma simples transposição de problemas sociais para um espaço"96 ou "fazer com que o urbano seja apenas um parâmetro secundário na expressão de uma questão social $[\ldots]^{\prime \prime 97}$ (DONZELOT, 2006, p. 34).

Donzelot ainda nos ajuda a construir o percurso rumo a compreensão da produção do espaço da aglomeração urbana de Paris numa perspectiva ainda mais abrangente a partir da dimensão do urbano e das variadas formas espaciais configuradas na sociedade urbana. O autor parte da premissa que desde o século XIX o domínio espacial do urbano vem se alargando sobremaneira e que, após mais de um século, o modo de vida urbano absorveu toda a sociedade. Assim, a modificação de suas formas espaciais contém os fundamentos e as contradições da realização da sociedade urbana.

O autor esclarece que a cidade compacta do século XIX, espacialmente limitada constrangia e confrontava ricos e pobres na sua forma ainda fechada e estreita. Posteriormente, e especialmente hoje, a forma urbana ganha seu plural e se modifica

por causa da relativa insegurança que algumas pessoas experimentam em contato com os outros, criando 0 surgimento de uma lógica de separação que faz com que os mais ricos fujam dos pobres e, ao fazê-lo, piorem a situação destes últimos ${ }^{98}$. (DONZELOT, 2006, p. 35).

\footnotetext{
95 Texto original: D'autres, dont nous-mêmes, préfèrent parler de question urbaine, donc d'une mise en cause de la ville, des tendances qui inspirent sa configuration et les transformations de celle-ci. [...] Nous serions censés vivre toujours le même problème : celui de la conflictualité des rapports sociaux de production, de l'insuffisante protection des classes laborieuses ». (DONZELOT, 2006, p. 34).

96 Texto original : « une simple transposition des problèmes sociaux dans un espace » (DONZELOT, 2006, p. 34).

97 Texto original: « Faire comme si l'urbain n'était qu'un paramètre secondaire dans l'expression d'une question sociale [...] » (DONZELOT, 2006, p. 34).

98 Texto original: « en raison de l'insécurité relative que les uns éprouvent au contact des
} 
Os princípios interpretativos da cidade e do urbano para a compreensão da produção do espaço propostas por Donzelot nos leva as formas espaciais do processo de périurbanisation na aglomeração urbana de Paris: les périurbains. Donzelot e Mongin (2013) apresentam uma crítica contundente a esse processo, e as consequências dele advindas.

Fazer a escolha pelo periurbano é uma forma de ter as vantagens do centro da cidade, seus equipamentos e seus locais de prestígio, sem o inconveniente de ter que contribuir com o custo de sua manutenção, uma vez que a área periurbana deve pagar impostos apenas para os municípios que não são muito exigentes a este respeito. Sem dúvida, esta distância da cidade central é paga, em troca, por maiores despesas de viagem e uma alienação do carro, que é um dos principais fundamentos da cidade franqueada [relativo às franquias]. De fato, quem paga o preço, em termos de poluição, de seu incessante ir e vir, se não de toda a sociedade: nesta dupla manifestação de egoísmo, acrescentam o pecado do voto xenófobo, uma rejeição do outro, o imigrante das cidades, neste caso. E agora o debate público está mudando dos relegados das cidades aos esquecidos dos periurbanos! Dificilmente pode ser melhor demonstrado que a distância da cidade resulta na perda das qualidades consubstanciais a ela, que são a partilha do espaço, o respeito dos lugares e a tolerância dos outros ${ }^{99}$. (DONZELOT E MONGIN, 2013, p. 18-19).

Donzelot (2004) considera que a cidade hoje se expande e se separa seguindo três ritmos que se complementam: relegaçãoperiurbanização-gentrificação ${ }^{100}$ (DONZELOT, 2004). Para o autor esses

autres, suscitant l'émergence d'une logique de séparation qui porte les plus aisés à fuir les plus démunis et, ce faisant, à aggraver la situation de ces derniers. » (DONZELOT, 2006, p. 35).

99 Texto original: «Faire le choix du périurbain, c'est une manière de pouvoir disposer des avantages de la ville centre, de ses équipements et de ses lieux de prestige, sans l'inconvénient d'avoir à contribuer au coût de leur entretien, puisque ledit périurbain ne doit verser des impôts qu'à des communes dortoirs peu exigeantes en la matière. Sans doute cet éloignement de la ville centre se paie-t-il, en retour, par des frais de déplacement plus élevés et une aliénation à la voiture qui est l'un des ressorts de «la ville franchisée. En effet, qui paie le prix, en termes de pollution, de leurs allers et retours incessants, sinon la société entière : à cette double manifestation d'égoïsme, ils ajoutent le péché d'un vote xénophobe, d'un rejet de l'autre, de l'immigré des cités, en I'occurrence. Et voilà que le débat public se déplace des relégués des cités aux oubliés du périurbain ! On ne peut guère mieux démontrer que l'éloignement par rapport à la ville se traduit par une perte des qualités consubstantielles à celle-ci que sont le partage de l'espace, le respect des lieux et la tolérance des autres. » (DONZELOT E MONGIN, 2013, p. 18-19).

100 Texto original : « relégation-périurbanisation-gentrification »(DONZELOT, 2004). 
três termos dão o ritmo, o movimento e as características da segregação socioespacial na produção do espaço no contexto da aglomeração urbana de Paris.

Tomando como base o trabalho de Berger (2004), Les périurbains de Paris: de la ville dense à la métropole éclatée, fomos buscar o princípio interpretativo para a compreensão do processo de periurbanização na França e a concomitante reestruturação dos espaços perimetrais da região parisiense. A autora pretendeu nesse trabalho compreender as transformações socioespaciais na aglomeração urbana de Paris objetivando

identificar na evolução das formas urbanas e modos de vida, os efeitos sobre as trajetórias sociais e espaciais de gerações de parisienses, em um contexto econômico em que sua cidade mudou escala e funções ${ }^{101}$. (BERGER, 2004, p. 12).

Berger nos apresenta outro princípio interpretação, o qual problematiza a reestruturação do sistema urbano franciliano ${ }^{102}$ a partir de um ponto de ruptura estruturante; antes o sistema sociopolítico, hoje o sistema socioeconômico. Nessa abordagem, a autora considera "analyser les traductions spatiales des recompositions sociales" (BERGER, 2004, p. 13).

De acordo com Berger, a periurbanização é uma característica específica do processo de metropolização franciliana e possui fundamentos no fortalecimento de uma classe abastada, com boa qualificação, cuja categoria profissional destaca-se entre a executiva e a intermediária (funcionários superiores do setor público, profissionais da informação, jornalistas, alguns profissionais da classe artística, professores universitários e pesquisadores, professores dos níveis médio e primário, profissionais da saúde, profissionais administrativos do setor privado, são alguns exemplos).

101 Texto original: «repérer dans l'évolution des formes urbaines et de modes d'habiter, les effets sur les trajectoires sociales et spatiales de générations de Franciliens, d'un contexte économique où leur ville changeait d'échelle et de fonctions. 》 (BERGER, 2004, p. 12).

102 Referente à região da Île de France. 
Nesse sentido, a ruptura que traz à tona as complexidades espaciais e as relações sociais de produção, possui um marco na estrutura urbana fundada e fortalecida pela lógica industrial e dominante na França até os idos dos anos 1960. Esse período marca o surgimento de formas urbanas mais complexas que dão simultaneidade às três características da produção do espaço, homogeneização-fragmentação-hierarquização ${ }^{103}$. Como exemplo, podemos citar os grandes conjuntos ou HLM (Habitations à Loyer Modéré) nas banlieues, a construção das villes nouvelles em eixos estratégicos da aglomeração urbana de Paris e os logements individuelles, emblemáticos nas áreas periurbanas parisienses.

Berger aprofunda sua problemática ao considerar que o periurbano se instala no campo impondo demandas urbanas, e assim, contribuindo para expansão do urbano sob as bases do rural contemporâneo e exigindo uma "releitura das relações entre cidade e campo"104 (BERGER, 2004, p. 275). O que é mais significativo nessa abordagem é perceber a astúcia dos agentes e atores envolvidos por interesses particulares ou coletivos na coexistência de "espaços pertencentes a vários ciclos de produção do urbano, engajados desigualmente no processo de recomposição ou então de reutilização ou revalorizações"105 (BERGER, 2004, p. 14).

É, portanto, retornando a obra de Vieillard-Baron que encontramos os elementos para pensar as transformações socioespaciais e suas elaborações teóricas, como possibilidade e limite de compreensão da produção do espaço no contexto do movimento de sua realização. Em Banlieue et péripherie, des singularités françaises aux réalités mondiales (2011), o autor, consagrado nos estudos urbanos da banlieue parisienne e suas transformações no tempo e no espaço, lança mão de uma

${ }^{103}$ Conforme apresentas anteriormente a partir de LEFEBVRE (1989) e LENCIONI (2017). 104 Texto orifinal: « relecture des relations entre villes et campagnes 》 (BERGER, 2004, p. 275).

105 Texto original: « espaces appartenant à des cycles variés de production de l'urbain, inégalement engagés dans la voie des recompositions sinon des réutilisations ou des revalorisations » (BERGER, 2004, p. 14). 
abordagem singular dos contextos histórico e político francês para refletir as realidades das periferias das grandes aglomerações urbanas mundiais.

Vieillard-Baron afirma que não há um consenso nos termos utilizados para caracterizar as áreas periféricas à cidade ou à metrópole. A banlieue, enquanto noção conceitual, é uma particularidade da língua francesa, porém enquanto fenômeno urbano não é uma especificidade da urbanização na França. Resta-nos conhecer as particularidades e semelhanças, inclusive teórico-conceituais, das produções acadêmicas sobre o tema. O autor acrescenta que, devido a expansão do urbano, as conciliações dos padrões e modelos de urbanização e a comparação dos tipos de organização social das periferias metropolitanas devem permitirnos abrir os horizontes das análises (VIEILLARD-BARON, 2011a).

Nossa reflexão pretende extrapolar o contexto francês e surge-nos a questão: como relacionar as singularidades francesas e brasileiras para problematizar a realidade urbana total? Se tomarmos como princípio interpretativo o movimento de estruturação-desestruturaçãorestruturação do espaço, quais características, rupturas e continuidades seriam evidenciadas pelos períodos de transformação em ambos os quadros analíticos? Em se tratando de aglomerações urbanas e tomando como referência a Metrópole Rio e sua região, quais as noções/conceitos que evidenciam as características do processo de metropolização e a relação desse com a produção do espaço?

Encontram-se no próximo item nossas reflexões decorrentes das questões aqui levantada. 
3.1.2. Olhares cruzados. As aglomerações urbanas Parisiense e Fluminense: um ponto de vista para a problematização da realidade urbana contemporânea

Inspirados na abordagem realizada por Kowarick na primeira parte de seu ensaio Viver em risco (2009), no qual o autor tem como objetivo discutir os conteúdos e contornos da questão social (no que se refere à vulnerabilidade e exclusão), suas perspectivas teóricas e sociopolíticas considerando as sociedades americana e francesa, vimos a importância de "cruzar olhares" em torno dos conceitos e problemáticas analíticas sobre a abrangência e as características gerais e especificas dos processos socioespaciais.

A partir de Kowarick percebemos que "cruzar olhares" não é o mesmo que comparar as diversas realidades mundiais, nacionais ou regionais, e sim, ampliar a compreensão da riqueza das concepções teóricas, a complexidade do real e as diferentes respostas sociopolíticas dos processos que se manifestam simultaneamente em toda a sociedade. Não estamos interessados em um diálogo teórico com o trabalho de Kowarick, mas sim em sua contribuição metodológica. O autor anuncia o seu objeto de pesquisa e o percorre em três ambientes sociopolíticos diferenciados (os Estados Unidos, a França e o Brasil) e ainda busca analisá-lo a partir das nuances do pensamento em cada contexto específico.

Dessa forma a questão social e a questão urbana se fundem na obra de Kowarick e podem ser analisadas e compreendidas simultaneamente. Resultado disso é o que o autor chamaria de espoliados da cidade e explorados no mundo do trabalho (KOWARICK, 2000). Essa simultaneidade é componente intrínseco do processo de produção capitalista. Logo, os grupos sociais não estão excluídos nem da produção do espaço nem das consequentes implicações dessa produção. Chamaríamos de grupos sociais urbanos, considerando a diferença entre 
os mais diversos componentes sociais do urbano e a classe social através da qual eles participam ativamente do processo de produção.

Essa noção de componentes sociais do urbano evoca-nos à interpretação dada por Vieillard-Baron ao utilizar a ideia de recomposição de periferias ${ }^{106}$. Sendo a periferia uma forma urbana manifesta historicamente na organização espacial da cidade e cada vez mais dominante na conformação espacial da sociedade urbana mundial, é imprescindível pensar novos conceitos e novos métodos para se analisar o futuro das aglomerações (VIEILLARD-BARON, 2011a). Para o autor, toda generalização é questionável; contudo, fato é que a expansão do urbano nunca mais deitou de representar transformações profundas e imprimir ritmos frenéticos às áreas periféricas das aglomerações urbanas. Esse princípio interpretativo trabalha a simultaneidade dos conteúdos das relações sociais de produção, sobretudo de produção do espaço, com as potencialidades explicativas contidas na dinâmica do pensamento sobre a cidade e o urbano. Ele também nos permite pôr em evidencia os agentes sociais, no limite e nas possibilidades de suas ações.

Alicerçados nesses argumentos encontramos na aglomeração urbana de Paris e na aglomeração urbana do Rio de Janeiro um recorte territorial que nos possibilitou amadurecer a problemática de pesquisa no que se refere a discussão da reestruturação do espaço, como processo e como conceito. São as cidades de Saint-Denis, ao norte de Paris, e a cidade de São Gonçalo, no eixo leste da aglomeração urbana do Rio de Janeiro (imagens 34 e 35).

106 Texto original: « recomposition des périphéries » (VIEILLARD-BARON, 2011a). 
Imagem 34 - Localização de Saint-Denis na petite couronne da aglomeração urbana de Paris.

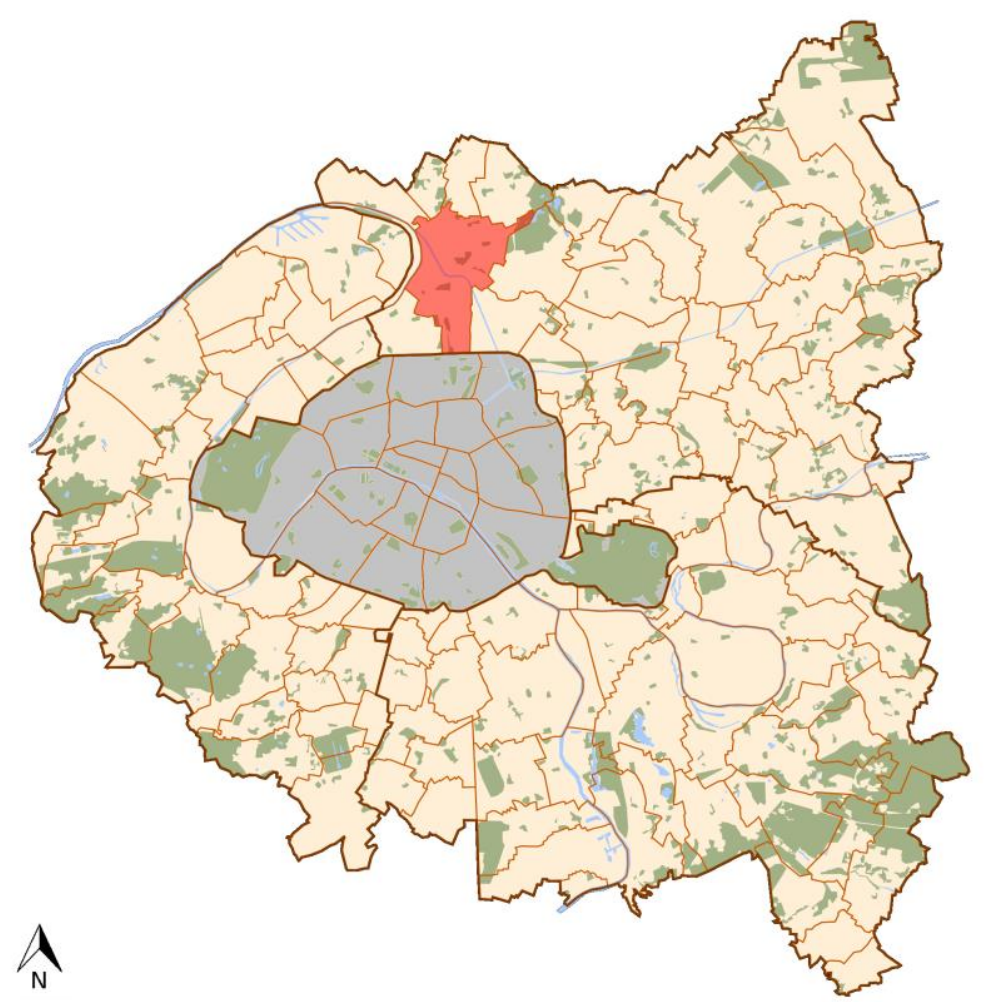

Elaboração: Juliana Luquez.

Imagem 35 - Localização de São Gonçalo na aglomeração urbana institucionalizada do Rio de Janeiro

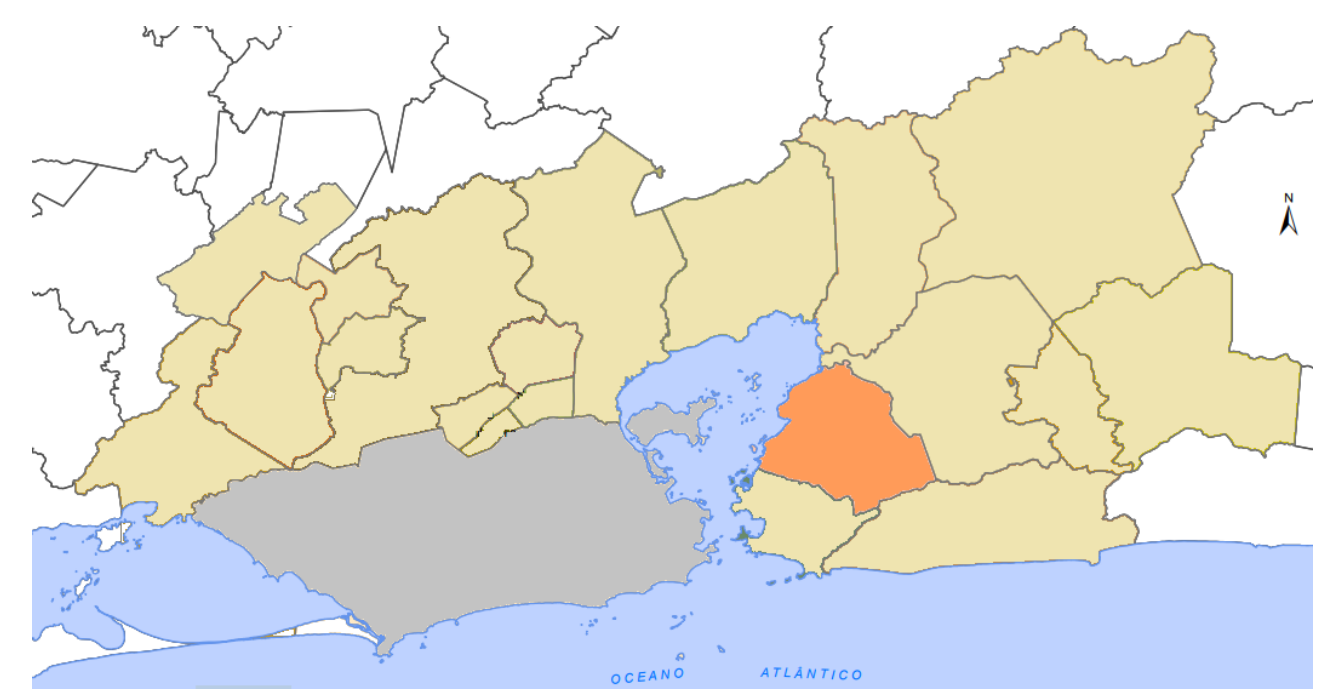

Elaboração: Juliana Luquez 
Por que tornou-se possível a análise relacional entre essas duas realidades urbanas? ${ }^{107}$

- Tratam-se de duas áreas onde a ruptura entre a estrutura urbanoindustrial e a metropolitano-financeira encontram representações nítidas:

A cidade de São Gonçalo favoreceu-se do desenvolvimento industrial na costa leste da Baía de Guanabara no período da plena industrialização e na nova conjuntura econômica fluminense (OLIVEIRA, 2008) baseada no novo ativo produtivo - a exploração do petróleo. O município também sofreu os efeitos da desindustrialização, especialmente com a saída das empresas instaladas e o consequente impacto para a classe operária.

Dois fatores contribuem atualmente para compreender as transformações socioespaciais da cidade de São Gonçalo: a reorganização do seu sítio em torno das atividades terciárias e, devido a sua posição bastante central dentro da aglomeração do Rio de Janeiro, o destaque para os investimentos imobiliários que visam atrair parcelas mais abastadas da população metropolitana para os enclaves. Os vazios industriais permanecem presos ao jogo de desvalorização-revalorização que ainda não ativou interesses privados e não destaca-se na agente dos projetos de renovação urbana dos entes públicos, constituindo-se em territórios de reserva fundiária. Esses territórios de reserva fundiária podem revelar as tendências do movimento do processo de reestruturação do espaço no contexto de sua produção.

No que se refere a cidade de Saint-Denis, percorremos o caminho ao contrário. Ou seja, dos territórios da reestruturação do espaço sob os domínios do urbano aos nexos da estruturação como centro industrial da aglomeração parisiense, ainda no século XIX até a metade do século XX. A centralidade da área aumentou nos últimos cinquenta anos com a ampliação das vias de comunicação (ferroviária, metroviárias, fluviais e

107 As contribuições dadas através das reuniões de orientação com o Professor Paul Claval e dos textos escritos por ele sobre as duas áreas nos foram úteis para desenvolver esse segmento. 
aerovias). E recentemente, a implantação do projeto Grand Paris Express ${ }^{108}$.

Este aumento de centralidade deveria ter facilitado 0 desenvolvimento da área, porém dois fatores devem ser considerados: 1 . a desindustrialização levou à proliferação de terrenos baldios industriais que só poderiam ser reutilizados após altos custos de reabilitação; 2. as indústrias desenvolvidas no século XIX foram, na sua maioria, bastante tradicionais, atraindo mão-de-obra não qualificada, grande parte constituída por imigrantes. Assim, com o declínio do emprego industrial, o desemprego se estabeleceu particularmente entre os jovens, a insegurança aumentou diante dos conflitos instigados pelas fraturas sociais marcantes.

- Apresentam grande concentração populacional no quadro estatístico de suas respectivas aglomerações, o que permite pensar os componentes sociais do urbano:

A cidade de São Gonçalo encontra-se no raio da maior densidade populacional da aglomeração urbana do Rio de Janeiro que, partindo do ponto central da Metrópole Rio, estende-se por até $28 \mathrm{~km}$ em direção à sua periferia. Possui a segunda maior concentração populacional do Estado do Rio de Janeiro, 1.049 .826 habitantes, cujo perfil socioeconômico caracteriza-se por: baixa escolaridade nos níveis médio e superior (mesmo com a presença de diversas instituições públicas e particulares de ensino nos dois segmentos de qualificação profissional e acadêmica); renda média mensal de trabalhadores formais de 2 salários mínimos que ocupam os postos das atividades de serviço, comércio e indústria, respectivamente (IBGE, 2015-2017); três grupos predominantes na composição demográfica, a população natural da

108 Serão $200 \mathrm{~km}$ de linhas automáticas, 68 estações, duas linhas prolongadas do sistema já existente e mais quatro linhas novas serão acrescentadas. O Grand Paris Express é o maior projeto urbano da Europa e está proposto para ser executado em 6 fases. Essencialmente subterrâneo, o novo metrô atravessará os territórios do Grand Paris para conectá-los uns aos outros e à capital. O projeto surge como uma nova alternativa para o uso demasiado do automóvel individual e aponta benefícios para 0 meio ambiente. Conforme <https://www.societedugrandparis.fr/>. 
região, os imigrantes inter-regionais (oriundos dos estados do Espírito Santo, Minas Gerais e da Região Nordeste do Brasil) e os novos moradores (esse último grupo se subdivide entre os novos moradores de recentes comunidades ou favelas e os novos moradores dos condomínios fechados construídos estrategicamente como "enclaves fortificados").

A cidade de Saint-Denis dista 7 km da Gare du Nord de Paris, possui 108.284 habitantes (Plaine Commune Grand Paris, 2015) e constitui-se de um mosaico cultural extraordinário, mesclando moradores tradicionais, imigrantes plurinacionais e também os novos moradores de um contexto mais recente de recomposição social e espacial da região. Esse último aspecto, inclusive, destaca-se pelo fato de a região da Plaine Commune de Saint-Denis ${ }^{109}$, na qual se insere a cidade, possui $81 \%$ de sua oferta de emprego no setor terciário. Essa modificação da atividade produtiva na região seguiu-se de uma política de renovação urbana com promoção do mercado imobiliário de habitação e escritórios e favorecia pelos investimentos públicos em mobilidade (trens regionais e tramway, por exemplo).

Vistas sob a ótica da teoria do campo urbano ${ }^{110}$ (CLAVAL, 1981), essas transformações reestruturaram o espaço urbano por meio de mecanismos fundiários e o refuncionarizaram a partir das demandas de mercado no contexto da globalização econômica e do papel das aglomerações urbanas na sua determinação.

Nosso objetivo não é comparar números e sim relacionar as transformações socioespaciais características das áreas periféricas das aglomerações urbanas. Assim, a questão urbana, sob as lentes da reestruturação do espaço, apresenta-se como movimento da totalidade na sociedade urbana, mas com caminhos mapeados por princípios interpretativos que devem estar atentos às especificidades da história da

\footnotetext{
109 Um território administrativo da aglomeração urbana de Paris no contexto das políticas de planificação e desenvolvimento territorial do Métropole du Grand Paris e que reforça a centralidade da cidade de Saint-Denis.

110 Texto original: «théorie du champ urbain » (CLAVAL, 1981).
} 
urbanização mundial: no caso de Paris, relégation, périurbanisation e gentrification (DONZELOT, 2004); no caso do Rio, periferização, espoliação urbana e segregação socioespacial.

- São cidades importantes nas dinâmicas urbana e econômica das aglomerações às quais estão inseridas e na atuação de agentes públicos e privados nos territórios metropolitanos:

A proximidade da cidade de São Gonçalo com a cidade de Niterói, o segundo núcleo urbano da aglomeração fluminense, contribui para um certo protagonismo da cidade nos arranjos territoriais das dinâmicas urbana e econômica do espaço. O intenso deslocamento intra e interurbano em direção aos locais de maior oferta de emprego e educação faz com que o eixo metropolitano São Gonçalo-Niterói seja o segundo maior do Brasil e o maior do Estado do Rio no que se refere ao fluxo diário de pessoas ${ }^{111}$.

São Gonçalo tem também a segunda maior frota de automóvel da aglomeração urbana institucionalizada, a Região Metropolitana do Rio de Janeiro - RMRJ (IBGE, 2015), o que contribui para diminuir a qualidade do ambiente urbano seja no aspecto ambiental ou no conforto das viagens de deslocamento. Esse é um fator que contribui para o aumento dos gastos médios do trabalhador; pois os custos de despesa e manutenção ${ }^{112}$ de um automóvel no Brasil está acima das médias salarias das periferias metropolitanas.

Na atual fase de desenvolvimento econômico do Estado do Rio de Janeiro, a cidade de São Gonçalo destaca-se no mapa das necessidades infraestruturais mais urgentes para o apoio logística à atividade produtiva,

\footnotetext{
${ }^{111}$ De acordo com o estudo "Arranjos Populacionais e Concentrações Urbanas do Brasil", realizado pelo IBGE em 2015, o maior fluxo de pessoas para trabalhar e estudar ocorre entre os municípios de São Paulo e Guarulhos (146,3 mil pessoas/dia) e o segundo maior fluxo ocorre entre as cidades de São Gonçalo e Niterói, ambas integrantes do arranjo populacional e metropolitano do Rio de Janeiro (120,3 mil pessoas/dia). O terceiro maior fluxo no Brasil e o segundo do Estado do Rio de Janeiro se dá entre a capital fluminense e o município de Duque de Caxias.

112 Referentes às ruas e autoestradas mal conservadas, alto preço do seguros devido aos altos índices de violência urbana, combustível, etc.
} 
tanto no setor voltado à extração do petróleo como no fortalecimento do setor de tecnologia de informação: transporte urbano de massa, como projetos de implantação do metrô nas áreas fora dos limites da Metrópole Rio; construção do Porto; ampliação da rede rodoviária no município; implantação de polos de formação técnico-profissional; etc.

O trabalho de campo realizado na cidade de Saint-Denis, sob a direção da pesquisadora Cécile Gintrac, nos apresentou a importância que a cidade tem na reafirmação de Paris como uma metrópole corporativa e global e transformação de territórios urbanos sob novas lógicas econômicas, tendo por exemplo, os megaeventos como promotores de oportunidades de mercado. Esse é um ponto pertinente na relação aqui proposta, pois trata-se de duas aglomerações sob às quais os impactos de grandes eventos produziram a necessidade de um balanço das transformações espaciais ${ }^{113}$. No caso de Paris, referimo-nos a Copa do mundo de 1998 e os Jogos Olímpicos a serem realizados em 2024. No primeiro caso, vimos no trabalho de campo a reprodução da Metrópole Paris em direção à sua banlieue ao norte através de uma explosão de infraestruturas relativas à produção e realização dos espetáculos. Nesse sentido, a reprodução da metrópole significou implantação e acesso as formas espaciais que dialogam com as determinações da estrutura metropolitano-financeira que, acreditamos, representar-se pela atual fase de reestruturações do espaço.

No caso do Rio de Janeiro, os Jogos Panamericanos de 2007, a Copa do Mundo de 2014 e as Olimpíadas de 2016 produziram oportunidade de reestruturação do espaço que foram realizadas com o intuído de fortalecer a centralidade da Metrópole Rio em relação à sua aglomeração urbana, concentrando todos os equipamentos urbanos nos limites territoriais da Metrópole, contribuindo, assim, para ampliar as desigualdades inerentes

\footnotetext{
113 Sobre esse tema sugerimos ver nosso artigo "Os desafios da Região Metropolitana do Rio de Janeiro na promoção da mobilidade sustentável: perspectivas pós olímpicas" (LUQUEZ, J. MUNIZ, J. FREITAS, L. Revista GEOFRONTER, set./2017). Disponível em: <https://periodicosonline.uems.br/index.php/GEOF/article/view/2129>.
} 
à produção do espaço nas áreas periféricas, uma vez que essas vão se reestruturando na explosão das contradições da Metrópole.

A relação proposta entre as aglomerações urbanas de Paris e do Rio, com ênfase nas cidades de Saint-Denis e São Gonçalo, respectivamente, representa também uma adesão ao pensamento crítico de Gintrac (2014) que nos inspira à seguinte formulação: a cidade explodiu, bem como suas contradições, em formas espaciais cada vez mais dispersas, contudo apropriar-se da cidade é investir em possibilidades mais criativas e posturas mais contestáveis acerca do processo de reestruturação do espaço. 


\subsection{As tríades do movimento}

O encadeamento do pensamento que desenvolvemos até aqui, certamente, alinha-se àquele pretendido por Lefebvre: pensar a construção do todo a partir de elementos que se relacionem entre si e com outros processos engendrados em totalidades possíveis.

No devir, existem estruturas que se constituem; depois o devir dissolve gradualmente ou destrói bruscamente as estruturas por ele criadas. Mas a dissolução ou a ruptura dos equilíbrios momentâneos, a desestruturação, não vem após a constituição das estruturas. É em meio aos equilíbrios, no coração das estruturas que atuam desde o início, que se encontram as forças que as dissolverão ou as romperão, que produzirão a desestruturação. [...]. Assim, a desestruturação opera no meio das estruturas, desde seu nascimento, antes mesmo de sua plena e inteira maturação. Jamais as estruturas podem se consolidar e se afirmar. $O$ negativo opera e trabalha no cerne do positivo. O possível não é exterior ao real, nem o futuro ao atual: eles já estão presentes e ativos. É o que faz a história. ${ }^{114}$ (LEFEBVRE, 1971a, p. 164).

Esse item final da exposição argumentativa tem como objetivo discutir e analisar a relação das rupturas apresentadas no capítulo anterior como características das fases de reestruturação do espaço e a simultaneidade com que as continuidades coexistem no movimento contraditório da produção do espaço, revelando-as através dos processos de periferização-espoliação urbana-segregação socioespacial. Esse recurso metodológico da análise triádica visa compreender o movimento histórico da dinâmica de produção do espaço também de maneira tridimensional, como já o evidenciamos antes: estruturação-desestruturaçãoreestruturação.

O pensamento triádico é uma interpretação que fazemos da

\footnotetext{
114 Texto original: «Dans le devenir, il y a des structures qui se constituent; puis le devenir dissout graduellement ou brise brusquement les structures qu'il a crées. Mais la dissolution ou la rupture des équilibres momentanés, la destructuration, ne vient pas après la constitution des structures. C''est au sein des équilibres, au ccoeur des structures qu'agissent dès le début les forces qui les dissoudront ou les briseront, qui produiront la destructuration. Ainsi la destructuration opère au sein des structures, dès leur naissance, avant même leur pleine et entière maturation. Jameis les structures ne peuvent se consolider et s'affirmer. » (LEFEBVRE, 1971a, p. 164).
} 
proposta metodológica de Lefebvre e a concebemos a partir de Lencioni (2017) e Schmid (2012). Para Lencioni

[...] isso decorre de sua visão triádica do mundo. $E$, indo mais além, da sua adjunção à visão dualista do mundo em que dois termos se contrapõem: o bonito ao feito, o bom ao mal, o capital ao trabalho, o pobre ao rico, Deus ao diabo, o saber popular ao saber erudito [...]. Vale lembrar ainda que o fato de se inspirar num marxismo hegeliano faz que as contradições examinadas não se estanquem na negação dos termos, ou seja, pelo conflito entre o primeiro e o segundo termo, se chega à negação de um outro. Vai além, não se situando na negação em si, mas a ultrapassando pela negação dela, ou seja, pela negação da negação [...] que tem positividade. Ou seja, que tem um conteúdo positivo, que contém um caminho para um novo começo. (LENCIONI, 2017, p. 18 e 19).

É importante a observação feita pela autora no que se refere a potencialidade do pensamento triádico superar a visão dualista do mundo, na qual uma dissolução ou uma ruptura pressupõe quase uma inércia da história e um recomeço sistêmico a partir do qual toda a realização da sociedade deve ser recontada, como se as contradições do Brasil agrário não guardassem premissas interpretativas para a compreensão do Brasil urbano, como se as relações sociais contidas na urbanização industrial não apresentassem continuidades na fase atual de urbanização metropolitanofinanceira. As tríades percebidas no movimento de produção do espaço contribuem para reconhecer rupturas e desvendar as continuidades que, oriundas de espaço-tempos históricos, coexistem no processo de reprodução das relações sociais.

Para Schmid

Seguindo a dialética hegeliana, a dialética de Lefebvre começa no nível do conceito: a identidade de um termo somente pode ser compreendida em relação a outros termos e assim em relação à sua própria negação. Assumir a existência de um objeto, então, também significa sempre assumir a existência de seu oposto. Um terceiro termo emerge de modo que nega e incorpora os outros dois. A postulação de um termo, desta forma, inicia um automovimento do termo que pode ser resumido na figura bem conhecida: afirmação, negação e negação da negação. 0 primeiro termo postulado, a afirmação, também contém nele 
mesmo sua negação que o nega e ao mesmo tempo o completa. Baseado em sua conexão interior, os dois termos exercem uma influência recíproca em cada um e produzem um terceiro termo no qual o primeiro termo reaparece mais bem definido e enriquecido, e também o segundo, cuja definição se junta ao primeiro. O terceiro termo volta-se contra o primeiro ao negar o segundo e assim redime o conteúdo do primeiro termo pela superação do que nele estava incompleto e limitado [...]. (SCHMID, 2012, p. 6).

A explicação do trecho acima pode ser melhor aproveitada quando tomamos três elementos, a nível do conceito, e os compreendemos no movimento da realização da sociedade: periferização-espoliação urbanasegregação socioespacial. Nas fases da reestruturação do espaço descritas no capítulo anterior - cada um desses elementos analíticos sobressai como prática espacial no processo de reprodução das relações sociais. Queremos dizer que, em cada momento do real o movimento de sua realização não só incorpora novas possibilidades contraditórias como também amadurece relações já desenvolvidas na determinação histórica de uma fase anterior.

Detalhemos. A periferização, entendida aqui como o processo que homogeniza a produção da periferia como um produto das relações sociais que assume uma dimensão espacial (CORRÊA, 1986) na urbanização capturada pela industrialização, insere-se na primeira reestruturação do espaço em São Gonçalo (1920-1960). Nesse sentido, a periferização, como prática espacial do primeiro momento da estruturação urbanoindustrial, funda-se como negação da própria cidade. A periferização é o processo que produz a forma urbana periferia, esta quase como o avesso da forma urbana cidade, o seu outro.

Se consideramos o entendimento conceitual de Corrêa sobre a periferia urbana, essa negação se manifestaria em dois níveis distintos e complementares.

Em realidade, pode-se falar em uma periferia suburbana ou subúrbio simplesmente, e em uma periferia rural-urbana. Tanto o subúrbio como a periferia rural-urbana são expressão dos processos sociais especializados, através dos quais a urbanização prossegue. [...]. É nesta periferia 
urbana, assim incompletamente definida por ora, que se verifica a mudança mais palpável do rural ao urbano. (CORRÊA, 1986, p. 70).

O autor apresenta o termo como importante marco para a compreensão do processo de urbanização a medida que este inaugura uma ruptura no espaço-tempo, uma mudança da determinação rural para a determinação urbana em função da reprodução do modo de produção capitalista. Tal mudança assume uma dimensão histórica e espacial. E tem como mediação as relações sociais efetivadas pelos agentes da produção do espaço para quem "a periferia urbana tem sido objeto de práticas territoriais das classes dominantes" (CORRÊA, 1986, p. 73). Dessa forma, a periferia nega a campo através do processo de incorporação imobiliária como propriedade fundiária na dinâmica de valorização do solo urbano e nega a cidade como forma de reprodução segregada das diferentes classes sociais no contexto da urbanização.

A periferia é a porção do espaço onde o movimento de estruturaçãodesestruturação-reestruturação como expressão da dinâmica de sua produção torna-se nítido em suas contradições. É nesse sentido que a reestruturação do espaço é aqui defendida como álibi à reprodução do capital: quando a própria periferia, cooptada para geração de valor, tem na propriedade de seus fragmentos o reforço da segregação - que em um espaço muito homogêneo se instaura cada vez mais acentuada. Ainda em Corrêa, encontramos dois exemplos dessa reprodução segregada conduzida, inicialmente, pelo processo de periferização e, posteriormente, pelo processo de espoliação urbana. O autor refere-se à periferia popular (interiorana) e a periferia elitizada (litorânea), que no caso do Rio de Janeiro exemplifica-se, a primeira pela região da Baixada Fluminense e São Gonçalo e a segunda pelas áreas litorâneas da Barra da Tijuca, Recreio dos Bandeirantes e Niterói.

Primeiramente, vejamos a periferia interiorana, aquela que não tem "mar, lagoa, sol, sal, brisa, verde, montanha", mas se caracteriza por ser quente, abafada, sujeita às enchentes e aos mosquitos. Esta é a periferia dos pobres, do "povão", do trem do subúrbio e horas desperdiçadas no transporte, 
da autoconstrução e do sobre-trabalho, das favelas que agora ali aparecem, dos assaltos e do esquadrão da morte, da falta de esgoto e de vias calçadas, escolas e hospitais. Dos desempregados, dos biscateiros e do pessoal que ganha salário-mínimo. De imigrantes recentes e as vezes antigos que, expulsos do campo não foram para as chamadas "frentes de expansão" [...]. As terras desta periferia foram, a partir do momento em que se verificou em maior escala o êxodo do campo para a cidade, loteadas pelos seus próprios proprietários [...]. O que fazer com estas terras que não constituem-se em alternativas para a classe dominante e a classe média? Vendê-las para fins industriais é uma possível alternativa, mas esse tipo de uso restringe-se a certas áreas, preferencialmente ao longo das grandes vias de tráfego. Realizar uma incorporação fundiária e imobiliária, construindo edifícios residenciais ou bairros arborizados e aprazíveis com casas confortáveis, está fora de cogitação. A clientela que se vê obrigada a morar nesta periferia não tem condições de comprar ou alugar estes imóveis, não dispondo mesmo de renda mínima para receber um financiamento do Estado para comprar um imóvel no setor privado. A alternativa que resta é o loteamento puro e simples [ou] estabelecer um forte "lobby" junto ao Estado para que este implante em sua propriedade um conjunto habitacional [...]. Ao novo proprietário do lote caberá construir a sua casa própria em um sistema de mutirão, com os amigos e parentes, durante umas horas de repouso e lazer. Mas ele aparentemente está satisfeito, pois será proprietário de imóvel, de algo que tem valor de uso e valor de troca: a ideologia da casa própria conforta-lhe e ameniza a exploração no seu trabalho. (CORRÊA, 1986, p. 73-75 grifos do autor)

O autor ainda oferece um contrapondo à periferia popular, o que nos permite identificar que a periferia homogeniza-se, hierarquiza-se e fragmenta-se e, assim, o processo de segregação socioespacial aprofunda o estranhamento e nega a aproximação das diferenças ao passo que as acentua. Temos o processo de segregação como a legitimação das diferenças e também como sua negação.

Vejamos agora o que acontece na periferia de amenidades [...]. Quando existe uma possibilidade efetiva de ampliar o espaço residencial para as elites e a alta classe média, iniciase o processo de valorização da área. O Estado capitalista, permeado de interesses fundiários e imobiliários - sobretudo na esfera municipal e estadual - investe maciçamente na infraestrutura da periferia em pauta: sua ação é espacialmente desigual, a favor da periferia aprazível e em detrimento da periferia do "povão". A implantação de ruas, 
luz, gás encanado, rede de esgoto, sistema viários incluindo, se necessário for, túneis e auto-estradas com viadutos, valoriza deste modo a propriedade fundiária. [...] O grande capital financeiro-fundiário-imobiliário cria então novos bairros. Cria "novas formas de morar", os condomínios exclusivos, cercados, policiados e dotados de uma ampla gama de serviços. [...]. A produção desta periferia elitizada constitui-se em um importante meio através do qual o capital reproduz-se e através do qual os grupos de elite encontram um meio favorável para reproduzirem-se: "condomínios", "shoppings centers" e clubes são suas expressões. Assim, periferia popular e periferia da elite são área especialmente opostas, mas inseridas ambas as duas na organização de uma sociedade de classes: são os locais de reprodução do exército de reserva e dos dirigentes. [...]. Mas não só isto. As diferenças marcantes de condições de vida vão traduzir-se em uma consciência das desigualdades sócio-espaciais. Esta consciência emerge através do conhecimento adquirido de todo o espaço urbano a partir da jornada para o trabalho, viagens para compras e visitas e dos meios de comunicação. (CORRÊA, 1986, p. 75 - grifos do autor).

Para Tanaka a noção periferia ${ }^{115}$ começa a ser cunhada ainda nos anos 1950, mas é a partir de 1970 que, junto às questões urbanas, ganha maior destaque tanto no debate acadêmico como nas ações dos entes públicos no contexto do desenvolvimentismo nacional baseado no crescimento econômico a partir da industrialização. Para a autora o termo periferia fora, inicialmente, utilizado para

Designar localizações da cidade destinadas preferencialmente à moradia da população trabalhadora de baixa renda. A ideia de periferia é utilizada para descrever a segregação socioespacial e desigualdades territoriais resultantes do modo de crescimento da cidade de São Paulo. [...]. A periferia é resultado das desigualdades de condições de infraestrutura e serviços públicos entre partes da cidade onde se concentram riquezas e atividades produtivas e as partes da cidade onde moram os trabalhadores urbanos. Sua caracterização é feita a partir de indicadores urbanísticos e habitacionais [...]: iluminação; rede de água e esgoto; tempo médio de deslocamento; traçado irregular das ruas e ausência de pavimentação; adensamento habitacional [...].

115 O termo periferia tornou-se bem usual na aglomeração urbana paulistana (CAMARGO et al, 1976). Outros termos como favela, comunidades e subúrbios populares (CAMPOS, 2005; FERNANDES, 2011; FERNANDES e PIÑON, 2010) tornaram-se mais referidos à realidade urbana do Rio de Janeiro. Embora cada termo guarde suas particularidades associados à diferentes formas de socialização, todos possuem 
São consideradas periferias os bairros e cidades dormitórios, onde predominam residências de população pobre trabalhadora e núcleos de moradia de trabalhadores urbanos associados aos núcleos industriais. (TANAKA, 2006, p. 44)

A contribuição de Tanaka destaca-se na associação que a autora faz dos processos de urbanização e industrialização para a compreensão da produção do espaço para além do ambiente construído da cidade sob a determinação urbano-industrial. A autora destaca uma estratégia desenvolvida pelo mercado imobiliário que, ao nosso ver, cunhou o caráter espoliativo do processo de reestruturação do espaço nas aglomerações urbanas. Trata-se da combinação entre acumulação e especulação, que faz crescer uma cidade "permeada por vazios, retidos para a valorização" (TANAKA, 2006, p. 45).

Explorando ainda mais essa perspectiva, temos em Mautner a interpretação de que a periferia, como uma fronteira de expansão do capital, é produto social, no contexto urbano, "pronto para ser incorporado à cidade" (MAUTNER, 2004, p. 252). Em outras palavras,

[...] consideramos a periferia como base de um processo de produção do espaço urbano. A periferia é de fato o local onde vivem os pobres, é socialmente segregada, e o preço da terra é baixo, porém, ao mesmo tempo, é um local mutante, sempre reproduzido em novas extensões de terra, enquanto velhas periferias são gradualmente incorporadas à cidade, ocupadas por novos moradores e reorganizadas pelo capital. (MAUTNER, 2004, p. 254).

A periferia como negação da cidade passa a ser a ela incorporada pelas dinâmicas de valorização e especulação da propriedade da terra ou de imóveis. Esses processos dão novos ritmos à reestruturação do espaço que realiza as relações sociais de produção na contradição do processo espoliativo. A periferia incorporada ainda é a negação da cidade, mas também a sua realização. O movimento de reestruturação indica o caminho da materialização espacial do processo de espoliação urbana que insere-se como a característica mais latente da segunda fase de reestruturação do espaço, considerada a partir da realidade urbana de São Gonçalo (1970-1990). Tendo a análise da periferização como o ponto de 
partida, o segundo termo que une-se ao primeiro é o de espoliação. O termo refere-se a um processo que, devido a hierarquização do espaço, está circunscrito naquela periferia popular a qual se refere Corrêa ou àquela periferia desadjetivada (a periferia total), no entendimento de Tanaka e Mautner.

O processo de espoliação urbana acentua os conflitos entre os agentes produtores do espaço urbano, especialmente no que tange os interesses na acumulação de capital e na reprodução da força de trabalho necessária ao processo produtivo. A periferia torna-se um produto social e uma forma urbana da luta de classes na cidade, e o Estado protagoniza o papel de mediador dessa luta. Consideremos o entendimento de Kowarick a esse respeito.

[...] a espoliação urbana está intimamente ligada à acumulação do capital e ao grau de pauperismo dela decorrente. Isso porque os trabalhadores assalariados e autônomos ou os desempregados são também moradores espoliados, e, sobretudo, porque é a dinâmica de criação e apropriação do excedente econômico que gera esses dois aspectos interligados da reprodução dos trabalhadores. Eles são, contudo, mediatizados pela ação do Estado, que regula as condições de trabalho e de remuneração e, de maneira direta ou indireta, gera os bens de consumo coletivo essenciais à reprodução urbana dos trabalhadores. Dessa forma, mesmo quando os graus de pauperização são mantidos inalterados, rebaixados ou minorados, os padrões de reprodução urbana poderão melhorar ou piorar em razão do que os moradores consigam obter do poder público em termos de serviços e equipamentos coletivos, subsídios à habitação ou facilidades de acesso à terra provida de infraestrutura. Esses processos variam segundo conjunturas políticas e podem ou não estar associados às conquistas na esfera das relações de trabalho. Pode-se dizer, em suma, que a espoliação urbana [...] decorre, convém insistir, do processo de acumulação do capital, mas também da dinâmica das lutas e reivindicações em relação ao acesso à terra, habitação e bens de consumo coletivo. Dessa forma, a questão fundamental reside na capacidade dos vários grupos e camadas sociais de pressionar e obter do Estado esses elementos básicos para sua sobrevivência nas cidades. O papel do Estado é fundamental, não só pelas razões já arroladas, mas também porque o investimento que injeta no tecido urbano é fator de intensa valorização diferencial da terra, aparecendo como ator importante no processo de 
especulação imobiliária e segregação social. (KOWARICK, 2000, p. 22).

O processo de espoliação urbana potencializa a periferia nas suas diferenças. Dessa maneira, uma outra tríade faz-se importante à compreensão: homogeneização-fragmentação-hierarquização. Para Lefebvre essa é a tríade constitutiva do espaço da sociedade capitalista aqui a tomamos como premissa para a discussão da tríade que propomos na análise da realidade urbana apresentada, Lencioni (2017) desenvolve mais a fundo essa referência analítica.

Se o espaço é homogêneo, fragmentado e hierarquizado, o processo espoliativo contido nas relações sociais de produção (do espaço e das coisas sobre o espaço) possui uma dimensão de exploração, dominação e controle inscrita no processo de urbanização. Essa urbanização passa, a partir do marco espaço-temporal da segunda reestruturação, a ser dirigida categoricamente pelo Estado. Para Fernandes (2006), em sua pesquisa embrionária, o Estado e a urbanização da cidade do Rio de Janeiro e, posteriormente, em uma escala nacional, guardam uma relação digna de relevância analítica. Para o autor, esse Estado produziu e modelou um espaço urbano estrategicamente sob bases militares. Se o fez até o início do século XX "quando começa o chamado processo de modernização e profissionalização das forças armadas" (FERNANDES, 2006, p. 3), mais ainda se intensificou a partir dos anos 1960 , pois

como se sabe, por parte das forças armadas a década de 60 corresponde também ao clímax de sua crescente interferência na vida política e social do Brasil. É um marco para a história política das organizações militares, do país e da própria cidade. (FERNANDES, 2006, p. 3).

Assim, o processo espoliativo é marcado pelo papel do Estado, mas um Estado autoritário, caracterizado pela ditadura militar instaurada entre 1964-1985, em que suas políticas de intervenção no espaço só fizeram acirrar as desigualdades e contradições da luta dos trabalhadores explorados e dos moradores espoliados, pois no que se refere à 
capacidade desse trabalhador urbano de "pressionar e obter do Estado esses elementos básicos para sua sobrevivência nas cidades" (KOWARICK, 2000 , p. 22), por meio de articulações e organizações sociais, porém estas também estavam sob o controle autoritário do Estado provedor. Contraditoriamente, nesse período, os movimentos sociais urbanos foram muito atuantes na reivindicação que visava a obtenção de equipamentos de consumo coletivo (água, esgoto, transporte, etc.), entretanto alguns desses movimentos, vinculados em cada caso a um bairro e sua específica associação de morador, ia declinando ao passo que as reivindicações eram modestamente satisfeitas. Obviamente a conjuntura política tendia ao constrangimento de grupos sociais atuantes ${ }^{116}$ e a fragmentação teve também sua dimensão política.

Essa fragmentação do espaço (e da vida urbana), no período de reestruturação orientada pela urbanização de Estado, se fez acompanhar pelo processo de segregação socioespacial que aprofundou a aproximação das diferenças e das reivindicações já constrangidas pelo Estado autoritário. A terceira fase do processo de reestruturação (2000-até o presente), é então, a expressão do termo segregação em sua máxima articulação com os processos de periferização e espoliação na dinâmica de produção do espaço da realidade urbana analisada.

Para além de uma diferenciação dos locais de residência das classes sociais, a segregação constitui-se um produto social e um arranjo espacial da reprodução das diferenças.

A segregação espacial insere-se na produção do espaço, consistindo, juntamente com as suas consequentes formas, em um dos mais importantes processos do espaço urbano. A distribuição das áreas industriais, das áreas de lazer, dos espaços públicos, dos locais de consumo, das vias de tráfego e dos meios de transporte, das escolas e dos hospitais, da limpeza e da segurança pública está, em diferentes graus, ligada à segregação espacial, exibindo também uma nítida

116 Contudo, não se deve negar o importante papel desenvolvido pelos movimentos sociais urbanos que construíram com grande êxito uma pauta da luta de classes na escala da cidade sem precedente, mesmo sob forte repressão dos "anos de chumbo". A esse respeito Maricato (2011) tem importante reflexão. 
espacialidade diferencial. [...]. Produto social, a segregação espacial constitui também um meio no qual a existência dos diferentes grupos sociais se efetiva. Produto e meio, a segregação é parte integrante dos processos e formas de reprodução social, pois a relativa homogeneidade interna de cada área social cria condições da reprodução da existência social que ali se verifica. Há, em realidade, uma profunda conexão entre segregação e classes sociais [...]. Políticas públicas, acumulação de capital, estratégia de sobrevivência são parte integrante da produção da segregação espacial. [Verifica-se] significativas mudanças na urbanização, incluindo a criação de novos centros urbanos, com possíveis reflexos nos processos e formas de segregação espacial (VASCONCELOS et al, 2013, p. 9 e 10).

Lago, no artigo intitulado $A$ "periferia" metropolitana como lugar do trabalho: da cidade dormitório à cidade plena (2007), analisa essas "significativas mudanças na urbanização" ao considerar, a partir de uma nova configuração social e espacial, a superação da periferia como categoria de análise. A autora parte da premissa que uma nova configuração metropolitana produziu uma superação do conceito, mas não necessariamente de sua essência. A noção de periferia, também chamada por Lago de "cidade-dormitório", reuniria a "síntese das carências e das enormes distâncias a serem percorridas diariamente entre o lugar da moradia e o do trabalho" (LAGO, 2007, p. 9). A autora sugere que a periferia recompõe-se negando a si mesma ao superar seu conteúdo, mas não a essência das relações sociais contidas em sua produção. A análise da autora reforça o caráter espoliativo com o qual a nova configuração metropolitana reorganização o trabalho e mobilidade dos trabalhadores urbanos pela metrópole e pelas cidades metropolitanas.

[Os anos 2000] indicavam uma forte mudança no percentual e no volume de pessoas que não saíam diariamente de seu próprio município de residência na periferia metropolitana para trabalhar. [...]. Em síntese, houve uma redução da mobilidade casa-trabalho de longa distância para os moradores da periferia, o que permite pressupor que o mercado de trabalho não só se expandiu nessas áreas, mas absorveu parte da mão de obra local. [...]. Uma primeira explicação para tal fenômeno seria que o aumento da imobilidade espacial dos trabalhadores estaria relacionado à expansão da economia informal precária nas áreas periféricas, inclusive nas mais distantes do centro, 
evidenciando uma descentralização econômica "perversa", ou seja, áreas populares desconectadas dos centros que abrigariam uma economia precária de "auto-subsitência". Em outras palavras, o "ganho" com a proximidade do trabalho estaria atrelado a "perda" quanto à natureza desse trabalho. [...]. Um segundo argumento para o referido aumento de pessoas trabalhando em seu próprio município de residência seria 0 maior dinamismo econômico em subcentros periféricos com a ampliação do mercado de trabalho local, especialmente para os setores médios. [...]. A elevação do perfil social em determinadas áreas, por exemplo, pode estar relacionada tanto à ampliação do mercado de trabalho local quanto à expansão da produção imobiliária empresarial para setores médios não integrados social e economicamente ao seu local de residência. (LAGO, 2007 , p. 11 e 22 - grifos da autora).

No primeiro capítulo desse volume apresentamos os mapas 4 e 5 . E é pertinente que voltemos a eles para avançarmos na contribuição de Lago. O mapa 4, referente aos fluxos de deslocamentos para trabalho e estudo entre municípios da Região Metropolitana do Rio de Janeiro (2015), permite-nos inferir que, mesmo com novas possibilidades produtivas em áreas populares da Região Metropolitana, essas podem sinalizar relações de trabalho menos formais apontando para uma maior instabilidade da renda. A ampliação dos postos de trabalho em áreas populares, como destaca Lago, parece apontar para uma nova determinação no padrão de acumulação do capital simultaneamente à uma nova configuração espacial da segregação. 0 mapa 5, relativo aos fluxos intra e interurbanos em São Gonçalo, nos dá uma atualização da interpretação de Lago acerca da periferia como lugar de trabalho. Nesse mapa a dinâmica regional apreendida nos percursos intra e interurbanos realizados diariamente entre São Gonçalo e as demais municipalidades da Região Metropolitana do Rio de Janeiro estão fortemente ligados à atual fase de reestruturação do espaço. Uma vez que, essa dinâmica não se realizou pelos investimentos infraestruturais ou políticas públicas de incentivo à produção e ao emprego industrial, mas sim pela reconfiguração do espaço que amplia a reprodução capitalista pelo setor imobiliário e pelo consumo de massa, fazendo com que São Gonçalo reproduza na relação com sua área de influência a mesma dinâmica que se processa na sua relação com 
as cidades do Rio de Janeiro e Niterói. A produção do espaço e a reprodução do capital, na escala metropolitana, tem no processo de reestruturação seu álibi e no de segregação a continuidade de suas contradições históricas na relação entre as classes sociais e o espaço que suas lutas produzem - e nas lutas que são travadas pelo espaço como produto de suas relações.

Ainda considerando a referência de Lago (2007), sua elaboração teórica sobre "cidade plena", anunciada no título de seu artigo, nos parece inacabada ou inapropriada. Isso porque, consideramos que as contradições da luta de classes estão contidas nas relações sociais que produzem a cidade (seja no centro ou nas periferias, favelas e subúrbios metropolitanos) e que, agravando-se o processo de segregação, a plenitude do espaço como produto social está cada vez mais comprometida. Avançando o pensamento da autora, sua pesquisa nos dá pressupostos para pensar uma transição da segunda fase para a terceira fase de reestruturação a partir do termo segregação, este processo não só integrante, mas fundamental para a compreensão da atual fase da produção do espaço, na qual homogeneização-fragmentaçãohierarquização constituem uma importante tríade dialética na análise e compreensão das novas configurações espaciais.

Reconhecimento que a realidade social é marcada por contradições e, logo, tal realidade só pode ser entendida a partir da compreensão dessas contradições, a segregação socioespacial torna-se o negativo da vida urbana; pois a segunda compreende celebração da diferença, e a primeira é uma constatação, na atual forma urbana, do isolamento das possibilidades diferenciais. Essa contradição, simultaneamente, preserva e exacerba o processo de segregação, conduzindo-o a um nível mais elevado e instaurando novos ritmos ao constante movimento de reestruturação do espaço.

$\mathrm{Na}$ introdução de seu livro $A$ situação da classe trabalhadora na Inglaterra, Engels (1845 [2010]) nos fornece alguns caminhos 
interpretativos para problematizar a realização da sociedade entre os momentos de rupturas e as continuidades subordinadas a essa realização. Para Engels o proletariado é a continuidade histórica da sociedade e qualquer transformação nas relações sociais, transformará ambos. E uma ruptura na formação econômico-social de qualquer realidade social, permite, especialmente ao proletariado, intentar movimentos autônomos. Partindo dessa premissa, a Revolução Política foi a maior das rupturas para a França, a Revolução Industrial foi a maior das rupturas para a Inglaterra, a Revolução Filosófica para a Alemanha e a Revolução Urbana ${ }^{117}$ moderna para várias formações econômico-sociais como, por exemplo, o Brasil.

As continuidades na realização da sociedade urbana no Brasil, periferização, espoliação urbana e segregação, foram aqui postas em um quadro analítico específico, a sociedade urbana fluminense. Porém, acreditamos que o processo que as revelou tenha sido o de reestruturação do espaço, que para além das continuidades, nos fez refletir sobre rupturas e transformações da realidade urbana como uma totalidade real e possível.

A problemática do espaço torna-se como uma questão ímpar para desvendar os meandros da reprodução do capital na contemporaneidade. O aprofundamento do pensamento a partir das tríades complexifica a perspectiva espacial e supera um inventário que ocupe-se de enumerar transformações, mas proponha uma compreensão da produção do espaço como um movimento total, instável e desequilibrado e, por isso, constantemente reestruturado.

\footnotetext{
117 Revolução Urbana entendida aqui a partir de Lefebvre (2008). Em suma, para o autor, trata-se do momento histórico no qual "as transformações operadas no campo pelo desenvolvimento da mercadoria, acompanhadas, acompanhadas da decomposição da cidade na qual esse mesmo mundo, através da industrialização, se aninhou e expandiu", sob o movimento de implosão-explosão, "não mais permitiam que se continuasse pensando em termos de cidade e campo, pois se tratava de um processo, mais amplo, profundo e dialético: a urbanização da sociedade, processo desconcertante para 0 pensamento e para ação". (LEFEBVRE, 2008, p. 8).
} 
Desta forma, acreditamos que a análise da reestruturação do espaço de São Gonçalo contribui também para aguçar a problemática acerca das dinâmicas de reestruturação da metrópole e de sua região, uma vez que essa análise se deu a partir da identificação das rupturas e transformações da cidade na relação com a metrópole. Esclarecendo o movimento em curso da reestruturação do espaço e contribuindo no uso metodológico do pensamento triádico, de termos como: estruturação-desestruturaçãoreestruturação; periferização-espoliação-segregação; produto-produçãoreprodução; homogeneização-fragmentação-hierarquização; formafunção-estrutura; etc.

A tríade forma-função-estrutura (LEFEBVRE, 1971b), por exemplo, pode ser instrumento metodológico relevante para revelar a dinâmica da produção do espaço, espaço que responde às alterações da sociedade a medida que ele, o espaço, também a altera, resultando na transformação dos lugares e de seus elementos. A forma urbana congrega um movimento de explosão-implosão, ou seja, a partir da implosão a "vida urbana concentra e se acentua no que resta da antiga morfologia (cidades e bairros)"; e a partir da explosão a vida urbana "tende a existir como forma nova que espera por uma base morfológica; [...] provocando o questionamento das formas existentes e do modo de existência (social e metal) das formas" (LEFEBVRE, 1991, p. 188). As formas se materializam pelas relações concretas entre os indivíduos e por isso se expressam na historicidade das relações sociais, atreladas ao conteúdo da vida urbana que determina suas funções dentro de uma estrutura organizada social e espacialmente.

As noções de forma, função e estrutura, são colocadas por Lefebvre em uma perspectiva de "pluralidade das significações"

Como toda realidade, o espaço social depende, metodológica e teoricamente, de três conceitos gerais: a forma, a estrutura, a função. Isso quer dizer que todo espaço social pode tornar-se o objeto de uma análise formal, de uma análise estrutural, de uma análise funcional. Cada uma proporciona um código, um método, para decifrar o que 
inicialmente parece impenetrável. Esses termos parecem claros. Na verdade, eles arrastam atrás de si bastante obscuridade, pois cada um deles não escapa à polissemia (LEFEBVRE, 2006; p 121).

Esse sentido polissêmico nos coloca frente a um grande desafio. $O$ desafio da simultaneidade: pois as "formas, funções, estruturas são em geral dadas na e por uma materialidade que simultaneamente as une e as distingue" (LEFEBVRE, 2006; p 122). A importância dessas três categorias, forma-função-estrutura, na análise da produção do espaço converge nossa observação para a importância da compreensão do processo de reestruturação do espaço acreditando que este engloba a simultaneidade a qual se refere Lefebvre: união (continuidade) e distinção (ruptura). 
Para alguns estudiosos da filosofia heraclítica a lógica do movimento instala-se em tudo e em todas as coisas, o ser se realiza em um processo contínuo de alteração e transformação. Sem necessariamente entrarmos na perspectiva de Heráclito, tomemos, a partir de Berge (1969), traços de seu pensamento

O ser é, para Heráclito, movimento puro, anterior aos seres concretos [...]; o ser-movimento é uma substância menos como princípio de permanência, mas como identidade dentro das mutações [...]. É sempre no movimento, na passagem de um termo ao outro, que as contradições se identificam [...]. (BERGE, 1969, p. 32).

Nossa sutil aproximação com tal perspectiva se deu ao passo que vislumbramos desvendar o movimento da realidade urbana concreta, e não sistematizá-la em períodos isolados. As três fases de reestruturação em São Gonçalo nos permitiram lançar mão de uma referência metodológica para compreender a produção do espaço urbano fluminense na sua relação com a problemática urbano-regional.

A construção de uma periodização que se revela pelo movimento foi, de certo, nosso maior desafio. O exercício de analisar as transformações socioespaciais foi também um exercício de pensar o que talvez seja essa "passagem de um termo ao outro" na perspectiva heraclítica. E, do mesmo modo, a identificação de elementos que coexistem e são superados por outros, não enquanto sua negação, mas enquanto contradição.

Acreditamos que esse caminho permitiu cumprir o objetivo de compreender a produção do espaço a partir das fases do processo de reestruturação em suas rupturas e continuidades. As respostas às questões que surgiram foram reveladas no próprio percurso do movimento socioespacial que conformou e transfigurou a realidade urbana da cidade de São Gonçalo.

O encadeamento das questões propostas em análise (contidas em cada capítulo) fundamentam a tese aqui defendida, de que a dinâmica da produção do espaço urbano de São Gonçalo, inserida na conformação do 
espaço metropolitano fluminense, pode ser compreendida a partir de fases da reestruturação do espaço, suas rupturas e continuidades. A démarche buscou evidenciar dois momentos determinantes nesta dinâmica, o urbano-industrial e o metropolitano-financeiro, e considerou três fases críticas do processo de reestruturação: 1) a urbanização que precede a industrialização e é capturada por ela; 2) a urbanização espoliadora; e 3) a urbanização especulativa.

Nossos fundamentos se compuseram, primeiramente, na descrição da realidade urbana da síntese interpretativa proposta: a cidade de São Gonçalo no conjunto de suas relações urbano-regionais. Nossa abordagem privilegiou a conjugação e a justaposição de todos os elementos da análise. A problemática urbana, extraída da realidade metropolitana do Rio de Janeiro, pode revelar as rupturas e as continuidades do movimento de sua realização e reunir os pressupostos para sua periodização: rupturas estão para os momentos do movimento, assim como as continuidades para sua concretude. E é no processo de reestruturação do espaço que essa dinâmica ganha materialidade e revelam-se seus descompassos: o processo de reestruturação é tomado como o ponto de partida para o aprofundamento da compreensão sobre a produção do espaço. Processo esse que não se apreende sem a identificação de rupturas e a evidenciação de continuidades históricas.

Buscamos, em um segundo momento, discutir a simultaneidade e a dinâmica entre os processos de produção e reestruturação do espaço afim de identificar as fases críticas do movimento que os realizam. Foi possível perceber que as rupturas imprimem novos ritmos à urbanização ao mesmo tempo que este movimento carrega continuidade de tempos e espaços já consolidados na história. Essa discussão foi construída, inicialmente, a partir de premissas e perspectivas interpretativas de autores acerca da produção-reprodução, urbanização, metropolização, fragmentação e reestruturação, considerados ímpares em nossa reflexão.

Assim, a reestruturação do espaço define-se como expressão do 
movimento de sua produção que congrega elementos de sua totalidade histórica e contraditoriamente concreta. Afirmamos que as fases de reestruturação do espaço em São Gonçalo, no contexto da urbanização fluminense, contribuem para a compreensão da realidade metropolitana e revelam as características dos momentos e movimentos contraditórios da realização da sociedade urbana.

De subúrbio à cidade industrial à cidade dormitório à cidade metropolizada. Das bucólicas zonas citricultoras aos loteamentos populares aos produtos imobiliários contemporâneos. Da periferização à espoliação à segregação. Como compreender cada momento da urbanização de São Gonçalo sem os confundir ou os isolar? A saída proposta conduziu-nos ao amadurecimento do pensamento sobre a cidade e suas transformações. Transformações tais que apreendem-se nos processos descritos de sua realidade dinâmica, ou seja, tão importante quanto sinalizar transformações e metamorfoses, tendências e fatos novos, é elaborar o pensamento que os sintetizam.

A elaboração teórica que apresentamos ao final desse trabalho pretendeu, justamente, unir subsídios interpretativos à realidade urbana complexa - tão complexa que não nos bastou um quadro à brasileira, fezse coerente uma análise relacional da problematização à francesa para discutirmos a relação contraditória entre as rupturas e as continuidades que articulam os diferentes níveis da realidade urbana.

No propósito de aprofundar a compreensão do processo de produção do espaço considerando a simultaneidade e homogeneização da realidade urbana e das concepções teóricas como respostas interpretativas aos processos urbanos que se manifestam em escala planetária cumpriu-se ao cruzarmos os olhares e identificarmos que os momentos de ruptura e as continuidades podem, aqui e ali, homogeneizar o espaço sob o domínio do urbano, mas não anulam as peculiaridades históricas da formação de cada realidade. Se na França o movimento lê-se por processos como os de relegação-periferização-gentrificação, no Brasil o movimento da 
urbanização metropolitana, apreende-se pelos processos de periferizaçãoespoliação-segregação. E é isso que garante o não aniquilamento das diferenças e das possibilidades. Esse caminho nos permitiu apresentar cada uma das fases de reestruturação sem as confundir e sem as isolar no tempo ou no espaço, perseguindo um movimento de realização ainda não finalizado.

Nesse sentido, acreditamos que a análise da reestruturação do espaço em São Gonçalo contribuiu também para aguçar a problemática acerca das dinâmicas de reestruturação da metrópole e de sua região, uma vez que essa análise se deu na interface das relações entre a Metrópole Rio, São Gonçalo e as realidades urbanas análogas na Região Metropolitana do Rio de Janeiro. Nossa maior contribuição repousa, certamente, sobre o fato de reconstruir o movimento de reestruturação do espaço, considerando rupturas e continuidades, como possibilidade interpretativa do processo de sua produção. 
ABREU, Maurício de Almeida. A evolução urbana do Rio de Janeiro. 4. ed. Rio de Janeiro: IP, 2008.

AGLIETTA, Michel. Concentración y centralización del Capital. Itens: Definición y causas de la concentración del capital. In: Regulación y Crisis del Capitalismo. 3. ed. Ciudad de Mexico: Siglo Veintiuno Editores, 1986. p. 192-197.

AGNEW, John. A nova configuração do poder global. Caderno CRH [online], vol.21, n.53, p.207-218, 2008.

ALBECKER, Marie-Fleur [Thèse]. Recycler les premières couronnes des villes globales : politiques d'aménagement urbain et restructurations des banlieues industrielles de Paris et New York. Université de Paris I - Panthéon Sorbonne, doctorat en Géographie, 2014.

. Banlieues françaises (2005 - 2015). La banlieue parisienne, périphérie réinvestie?, Urbanités, oct./2015.

ANTAS JUNIOR, Ricardo Mendes. Notas sobre o uso do conceito de circuitos espaciais produtivos para estabelecer 0 nexo entre a reestruturação urbana e as refuncionalizações do espaço: um estudo sobre os fixos de saúde no Estado de São Paulo. In: Anais do XIV Encontro da ANPUR, Rio de Janeiro, 2011.

ANTUNES, Ricardo. Os sentidos do trabalho: ensaio sobre a afirmação e a negação do trabalho. 2 ed. São Paulo: Boitempo, 2000.

ARAÚJO. Leila de Oliveira Lima. Imagens urbanas contadas por meio da paisagem: a antiga região industrial de Niterói e São Gonçalo - RJ. Dissertação de Mestrado (Geografia) - Instituto de Geociências, Universidade Federal Fluminense, Niterói, 2002.

ASCHER, François. Métapolis, ou l'avenir des villes. Paris: Odile Jacob, 1995.

Les nouveaux príncipes de l'urbanisme, la fin des villes n'est pas à l'ordre du jour. La Tour d'Aigues: L'aube, 2001.

. L'agê des métapoles. La Tour d'Aigues: L'aube, 2009.

BASTIÉ, Jean. Géographie du Grand Paris. Paris: Masson, 1984.

BASTIÉ, Jean; DÉZERT, Bernard. La Ville. Paris: Masson, 1991.

BEAUjeU-GARnier, Jacqueline; BASTIÉ, Jean (Orgs.). Atlas de Paris et 
de la région parisienne. Paris: Éditions Berger-Levrault, 1967.

BERGE, Damião. O logos heraclítico. Introdução ao estudo dos fragmentos. Rio de Janeiro, Instituto Nacional do Livro, 1969.

BERGER, Martine. Les périurbains de Paris. De la ville dense à la métropole éclatée ? Paris : CNRS Éditions, 2004.

BERNARDES, Lysia; SOARES, Maria Therezinha Segadas. Rio de Janeiro: cidade e região. Rio de Janeiro: Biblioteca Carioca, 1990.

BERTHO, Alain. Banlieue, banlieue, banlieue. Paris: La Dispute, 1997.

BÉHAR, D. Le projet du grand Paris peut-il ignorer la question sociale ? Revue Esprit, p. 158-162, déc./2009.

BRAGA, Maria Nelma Carvalho. O município de São Gonçalo e sua história. 3. ed. Niterói: Nitpress, 2006.

BRENNER, Neil. Teses sobre a urbanização. In: E-metropolis. Rio de Janeiro: Observatório das Metrópoles, n. 19, ano 5, dez./2014, p. 6-25.

BONDUKI, Nabil. Origens da habitação social no Brasil: arquitetura moderna, lei do inquilinato e difusão da casa própria. 6 ed. São Paulo: estação Liberdade, 2013.

BOTELHO, Adriano. O urbano em fragmentos: a produção do espaço e da moradia pelas práticas do setor imobiliário. São Paulo: Annablume, 2007.

BOYER, Jean-Claude. Les Banlieues en France. Paris: Armand Colin, 2000.

BRUNET, Roger ; FERRAS, Robert; THÉRY, Hervé. Les mots de la Géographie : dictionnaire critique. Paris : La Documentation Française, 1997.

BURGEL, Guy. (Org). Essais critiques sur la ville. Gollion: Infolio, 2015a.

Géographie urbaine. Vanves: Hachette, 2015b.

La ville aujourd'hui. Paris: Hachette, 1993.

CAMARA METROPOLITANA DE INTEGRAÇÃO GOVERNAMENTAL DO RIO DE JANEIRO. Caderno metropolitano 2: centralidades, território de perspectivas para políticas públicas. Rio de Janeiro, mai./2017. 
. Revista Rio Metrópole: charrete metropolitana. Rio de Janeiro, nov./2015.

Revista Rio Metrópole: os desafios e os rumos de gestão das 19 cidades que integram a região. Rio de Janeiro, mai./2011.

CAMARGO, Cândido Procópio Ferreira de et al. São Paulo 1975 Crescimento e pobreza. São Paulo: Edições Loyola, 1976.

CAMPOS, Andrelino. Do quilombo à favela: a produção do espaço criminalizado no Rio de Janeiro. Rio de Janeiro: Bertrand, 2005.

CANO, Wilson. Ensaios sobre a crise urbana do Brasil. Campinas: UNICAMP, 2011.

CARLOS, Ana Fani Alessandri. A crise urbana. São Paulo: Contexto, 2015.

A (re)produção do espaço urbano. São Paulo: Edusp, 2008.

A condição espacial. São Paulo: Contexto, 2011.

CARMONA, Michel. Le Grand Paris: l'évolution de l'idée d'aménagement de la Région Parisienne. Bagneaux: Girotypo, 1979. (Tome II).

CASTELLS. Manuel. A questão urbana. 6 ed. São Paulo: Paz e Terra, 2014.

CASTRO, Roland; CANTAL-DUPART, Michel. Banlieues 89: Dossier d'information mars 85. Paris: Banlieues 89, 1985.

CHESNAIS, François (Org) A finança mundializada: raízes sociais e políticas, configuração, consequências. São Paulo: Boitempo, 2005.

CHESNAIS, François. A mundialização do capital. São Paulo, Xamã, 1996.

. Uma nova fase do capitalismo? São Paulo: Xamã, 2003.

CHESNAIS, François et al. Uma nova fase do capitalismo? São Paulo: Xamã, 2003.

CHILDE, Gordon. A evolução cultural do homem. 5 ed. Rio de Janeiro: Zahar.

CLAVAL, Paul. La logique des villes. Essai d'urbanologie. Paris: Litec, 
1981. 36, 2005.

Métropolisation et globalisation. In: CIDADES, v.2, no 3, p. 13. L'avenir de la métropolisation. In: Annales de Géographie, t.98, no 550 , p. 692-706, 1989.

La logique des villes. Essai d'urbanologie. Paris: LITEC, 1981.

. La métropolisation et la nouvelle distribution des acteurs sur la scène politique mondiale. In: Métropolisation et politique. Paris: L'Harmattam, 1997.

CLAVAL, Paul. De la logique des villes aux ressorts de l'urbanité. In: CUNHA, Antonio; MATTHEY, Laurent (Org). La ville et I'urbain: des savoirs émergents. Textes offerts à Jean-Bernard Racine. 2007.

CORRÊA, Roberto Lobato. O espaço urbano. São Paulo, 1993.

A periferia urbana. In: GEOSUL, $\mathrm{n}^{\circ} .2$, ano I, Florianápolis: UFSC, jul/1986, p 70-78.

CONSTANTINO, Wagner. $\mathbf{O}$ preço da fluidez: os pedágios nas rodovias paulistas e seus efeitos sobre a lucratividade das empresas do setor de máquinas e equipamentos, localizadas na Cidade-Região São Paulo. Tese de Doutorado (Geografia Humana) - Faculdade de Filosofia, Letras e Ciências Humanas, Universidade de São Paulo, São Paulo, 2016.

CRUZ, Rita de Cássia Ariza da. Introdução à Geografia do Turismo. 2 ed. São Paulo: Roca, 2003.

DAVIDOVICH, Fany Rachel. Estado do Rio de Janeiro: singularidades de um contexto territorial. In: Anais do VIII Encontro Nacional da ANPUR. Porto Alegre, 1999.

- Metrópole e território: metropolização do espaço no Rio de Janeiro. Cadernos Metrópole, Rio de Janeiro, n. 6, $2^{\circ}$ sem., p. 67-77, 2001b.

O entorno da região metropolitana do Rio de Janeiro, hipóteses e considerações. In: Anais do IX Encontro Nacional da ANPUR. Rio de Janeiro, ANPUR, p. 326-335, 2001a.

DEMANGEON, Albert. Paris, la ville et sa banlieue. Paris: Bourrelier, 1933. 
DESJARDINS, Xavier; BEAURICE, Francis. La ville prise aux mots. Éditions de la Sorbonne: Paris, 2017.

DESJARDINS, Xavier. La bataille du Grand Paris. Formation Géographique, 2010.

. Ce Grand Paris qui advient. Leçons pour la planification métropolitaine. Formation Géographique, vol. 80, n. 4, p. 96-116, 2016.

DONZELOT, Jacques; MONGIN, Olivier. Tous urbains, tous périurbains! In: ESPRIT, mars-avril, 2013.

DONZELOT, Jacques. La ville à trois vitesses: relégation, périurbanisation, gentrification. In: Esprit, Paris, mars-avril, 2004.

Quand la ville se défait. Quelle politique face à la crise des banlieues ? Paris: Éditions du Seuil, 2006.

DOMINGUEZ, Marcos Thimoteo et al. Gestão impositiva versus governança metropolitana: um estudo de caso sobre a FUNDREM. Rio de Janeiro: IPEA, 2014.

DUMÉNIL, Gérard; LÉVY, Dominique. Superação da crise, ameaças de crises e novo capitalismo. In: CHESNAIS, François et al. Uma nova fase do capitalismo? São Paulo: Xamã, 2003.

EDELBLUTTE, Simon. Que reste-t-il de l'industrie après la désindustrialisation ? De la négation au patrimoine industriel. In: Bulletin de I'Association de Géographes Français, 88 année, fev./2011.

ENGELS, Friedrich. A situação da classe trabalhadora na Inglaterra. São Paulo: Boitempo, 2010.

EPSTEIN, Renaud. La rénovation urbaine. Démolition-reconstruction de l'État. Paris : Sciencies Po Les presses, 2013.

FERNANDES, Nelson da Nóbrega; OLIVEIRA, Marcio Piñon de (Org). 150 anos de subúrbio carioca. Rio de Janeiro: Lamparina; EDUFF, 2010.

FERNANDES, Nelson da Nóbrega. O rapto ideológico da categoria subúrbio: Rio de Janeiro 1858-1945. Rio de Janeiro: Apicuri, 2011.

. Os militares e o espaço urbano do Rio de Janeiro: um programa de pesquisa em geografia urbana e geografia política. Scripta Nova, Barcelona, v. X, n. 218, p. 218-227, 2006. 
FERNANDES, Rui Aniceto Nascimento. Notas para uma história ambiental de São Gonçalo: processo de ocupação do território gonçalense. In: SANTOS, Marcelo Guerra (Org). Estudos ambientais em regiões metropolitanas: o município de São Gonçalo. Rio de Janeiro: Eduerj, 2012. p. 00-00.

FOL, Sylvie ; RAAD, Lina. Les politiques de patrimonialisation comme support de la gentrification en banlieue rouge ? Le centre ancien de SaintDenis. In: DJAMENT-TRAN; SAN MARCO (Org). La métropolisation de la culture et du patrimoine. Le Manuscrit: Paris, 2014, p. 259-284.

FRETAG, Bárbara. Capitais migrantes e poderes peregrinos: o caso do Rio de Janeiro. Campinas: Papirus, 2009.

FREHSE, Fraya. Potencialidades do método regressivo-progressivo: pensar a cidade, pensar a história. Tempo social, São Paulo: USP, v. 13, n. 2, nov. p. 169-184, 2001.

FINATTI, Rodolfo. Aglomerações industriais no Brasil: uso do território e transformações recentes. Tese de Doutorado (Geografia Humana) Faculdade de Filosofia, Letras e Ciências Humanas, Universidade de São Paulo, São Paulo, 2017.

FIORAVANTI, Lívia. Projetos de requalificação urbana em La Plaine SaintDenis, Paris: a gentrification além do discurso da mixité social. GeoTextos, vol. 11, n. 1, p.61-90, jul/2015.

GEIGER, Pedro Pinchas; SANTOS, Ruth Lyra. Notas Sobre a Evolução da Ocupação Humana na Baixada Fluminense. Revista Brasileira de Geografia, Rio de Janeiro: IBGE, v. 16, n. 4, jul./set. p. 291-313, 1954.

GEIGER, Pedro Pinchas. Urbanização e industrialização na orla Oriental da Baía de Guanabara. Revista Brasileira de Geografia, Rio de Janeiro: IBGE, v. 18, n. 4, out./dez. p. 47-74, 1956.

GEO, Le Grand Paris : de la proche banlieue aux villes nouvelles (dossier), no 153, novembre/32, 1991.

GIBLIN, Beatrice (Org). Dictionnaire des banlieues. Larousse, 2009.

GIDDENS, Antony. A constituição da sociedade. São Paulo: Martins Fontes, 2013.

GINTRAC, Cécile; GIROUD, Mathieu. (Org) Villes contestées. Pour une géographie critique de l'urbain. Paris: Les Prairies ordinaires, 2014. 
GOTTDIENER, Mark. A teoria da crise e a reestruturação sócio-espacial: o caso dos Estados Unidos. In: VALLADARES, Lícia; PRETECEILLE, Edmond (Org). Reestruturação urbana: tendências e desafios. São Paulo: Nobel; Rio de Janeiro: IUPERJ, 1990.

GRAVARI-BARBAS, Maria et al. Contre la métropole créative... tout contre. Les politiques patrimoniales et touristiques de Plaine Commune, SeineSaint-Denis, Metropoles [online], n. 17, 2015.

GURVITCH, Georges. As estruturas em sociologia. In: BASTIDE, Roger. (Org). Usos e sentidos do termo estrutura nas ciências humanas e sociais. São Paulo: Editora Herder/Edusp, 1971.

HARVEY, David. O novo imperialismo. São Paulo: Loyola, 2013.

. Espaços de esperança. São Paulo: Edições Loyola, 2009.

. Condição pós-moderna: uma pesquisa sobre origens da mudança cultura. São Paulo: Loyola, 2011.

. Os limites do capital. São Paulo: Boitempo, 2013.

. Paris, capital da modernidade. São Paulo: Boitempo, 2015.

HAUTREUX Jean; ROCHEFORT Michel. Physionomie générale de l'armature urbaine française, Annales de Géographie, 74, $n^{\circ} 406$, p. 660-677, 1965.

INSTITUT D'AMÉNAGEMENT ET D'URBANISME ÎLE DE FRANCE - IAU-IdF. Vers des nouvelles restructurations intercommunales en Grande Couronne (Note Rapide Territoires), 2014.

KOWARICK, Lúcio. Escritos urbanos. São Paulo: Editora 34, 2000.

A espoliação urbana. São Paulo: Paz e Terra, 1993.

. Viver em risco: sobre a vunerabilidade socioeconômica e civil. São Paulo: Editora 34, 2009.

LAGO, Luciana Corrêa do. A "periferia" metropolitana como lugar do trabalho: da cidade dormitório à cidade plena, Cadernos IPPUR, Rio de Janeiro, ano XXI, n. 2, p. 9-28, 2007.

LANGENBUCH, Juergen Richard. A estruturação da Grande São Paulo: estudo de geografia urbana. Tese de Doutorado - Faculdade de Filosofia, Letras e Ciências de Rio Claro, Universidade de Campinas, Rio Claro, 1968. 
LEFEBVRE, Henri. A re-produção das relações de produção. Tradução de Antônio Ribeiro e M. Amaral. Porto: Publicações Escorpiões, 1973. (Coleção Cadernos O Homem e a Sociedade).

. Du rural à I'urbain. Paris: Anthopos, 1970.

A revolução urbana. Belo Horizonte: EDUFMG, 2008.

. A vida cotidiana no mundo moderno. Ática: São Paulo, 1991.

O fim da história. Lisboa: Dom Quixote, 1971a.

. L'idéologie structuraliste. Paris: Éditions Anthropos, $1971 \mathrm{~b}$.

. O conceito de estrutura em Marx. In: BASTIDE, Roger. (Org). Usos e sentidos do termo estrutura nas ciências humanas e sociais. São Paulo: Editora Herder/Edusp, 1971c.

. O direito à cidade. 4. ed. São Paulo: Centauro, 2006.

. La production de I'espace. Paris: Anthropos, 2000.

. O pensamento de Lênine. Lisboa: Moraes, 1969.

. Quand la ville se perd dans la métamorphose planétaire. Le Monde Diplomatique, Paris, mai./1989.

. Da teoria das crises à teoria das catástrofes, GEOUSP, São Paulo, n. 25, p. $138-152,2009$.

. Le retour de la dialectique: 12 mots clefs pour le monde moderne. Paris : Messidor/Éditions Sociales, 1986.

. Espaço e política. Belo Horizonte: UFMG, 2016.

LENCIONI, Sandra. Concentração e centralização das atividades urbanas: uma perspectiva multiescalar. Reflexões a partir do caso de São Paulo. Revista de Geografia Norte Grande, v. 39, p. 7-20, 2008a.

. Observações sobre o conceito de cidade e urbano, Geousp, São Paulo, v. 24, p. 109-123, 2008b.

. Da cidade e sua região à cidade-região. In: LIMA, Luiz Cruz; ELIAS, Denise; SILVA, José Borzacchiello da (Org). Panorama da Geografia Brasileira I. São Paulo: Annablume, 2006. p. 65-76. 
. Metropolização do espaço e a constituição de megarregiões. In: FERREIRA, Alvaro; RUA, João; MATTOS, Regina Célia. (Org). Desafios da metropolização do espaço. Rio de Janeiro: Consequência, 2015.

. Metrópole, metropolização e regionalização. Rio de Janeiro: Consequência, 2017.

- Metropolização do espaço: processos e dinâmicas. In: FERREIRA, Alvaro; RUA, João; MARAFON, Glaucio José; SILVA, Augusto César Pinheiro da. (Org). Metropolização do espaço: gestão territorial e relações urbano-rurais. Rio de Janeiro: Consequência, 2013.

- Reestruturação urbano-industrial no estado de São Paulo: a região da metrópole desconcentrada. In: Espaço \& Debates, São Paulo, NERU, n.38, p.54-61, 1994.

- Reestruturação: uma noção fundamental para o estudo das transformações e dinâmicas metropolitanas. In: Anais do VI Encontro de Geógrafos da América Latina, Buenos Aires, 1998. p. 00-00.

A metamorfose de São Paulo: o anúncio de um novo mundo de aglomerações difusas. Revista Paranaense de Desenvolvimento, Curitiba, n.120, jan./jun. 2011, p.133-148.

- Condições gerais de produção: um conceito a ser recuperado para a compreensão das desigualdades de desenvolvimento regional. Scripta Nova Revista Electrónica de Geografía y Ciencias Sociales, Universidad de Barcelona, v. 11, n. 245, ago. 2007, p. 1-10.

LESSA, José Luís Honorato. A paisagem revelada: natureza da concentração industrial em São Gonçalo (RJ) - crise ou reestruturação da indústria local? Dissertação de Mestrado (Geografia) - Faculdade de Formação de Professores, Universidade do Estado do Rio de Janeiro, São Gonçalo, 2009.

LOJKINE, Jean. O papel do Estado na urbanização. In: FORTI, Reginaldo (Org). Marxismo e urbanismo capitalista. São Paulo: Editora Ciências Humanas, 1979.

MACHADO, Fábio Nunes. A atuação do poder público na construção do espaço urbano gonçalense, entre os anos 1920 - 1950. Monografia de Graduação - Faculdade de Formação de Professores, Universidade do Estado do Rio de Janeiro, São Gonçalo, 2002. 
MARICATO, Ermínia. O impasse da política urbana no Brasil. Petrópolis: Vozes, 2011.

2015

. Para entender a crise urbana. São Paulo: Expressão Popular,

MARICONI-EBRARD, François. L'urbanisation du monde depuis 1950. Paris: Anthropos, 1993.

MARTINS, José de Souza. O cativeiro da terra. 9. ed. São Paulo: Contexto, 2010.

Paulus, 2009.

Exclusão social e a nova desigualdade. 4 ed. São Paulo:

MARTINS, José de Souza (Org). Henri Lefebvre e o retorno à dialética. São Paulo: Hucitec, 1996.

MARX, Karl. O capital: crítica da economia política. Livro I: O processo de produção do capital. São Paulo: Boitempo, [1867]2013.

MAUTINER, Yvonne. A periferia como fronteira de expansão do capital. In: SCHIFER, Sueli Terezinha Ramos; DEÁK, Csaba (Org). 0 processo de urbanização no Brasil. São Paulo: EDUSP, 2004.

MENDES, Renato da Silveira. Paisagens culturais da Baixada Fluminense. Tese de Doutorado (Geografia Humana) - Faculdade de Filosofia, letras e Ciências Humanas, Universidade de São Paulo, São Paulo 1950.

MERLIN, Pierre. Les villes nouvelles en France. Paris: Presses Universitaires de France, 1991.

MODESTO, Nilo Sérgio D'avila. A (re)produção espacial em marcha na consolidação dos Grupos de Poder Hegemônico em São Gonçalo RJ. Tese de Doutorado (Geografia) - Instituto de Geociências, Universidade Federal Fluminense, Niterói, 2008.

MONBEIG, Pierre. O crescimento da cidade de São Paulo. In: SZMRECSÁNYI, Tamás (Org). História econômica da cidade de São Paulo. Porto Alegre: Editora Globo, 2004. p. 14-115.

MOREIRA, Ruy. Os quatro modelos de espaço-tempo e a reestruturação espacial brasileira. In: MOREIRA, Ruy (Org). A reestruturação industrial e espacial do estado do Rio de Janeiro. Niterói: UFF, 2003. 
MOTTA, Marcia Maria Menendes. Niterói Rural: elite de ontem e arrendatários de outrora (1808-1888). In: Martins, Ismênia de Lima; Knauss, Paulo (Org). Cidade múltipla: temas de história de Niterói. Niterói: Niterói Livros, 1997.

MUMFORD, Lewis. A cidade na história. Suas origens, transformações e perspectivas. São Paulo: Martins Fontes, 2008.

MUSÉE FRANÇAIS DE LA CARTE À JOUER. Peindre la Banlieue, de Carnot à Vlaminck (1850-1950): catálogo. Issy-les-Moulineaux, 2017, $158 \mathrm{p}$.

NATAL, Jorge. Revisitando o Rio de todas as crises: economia, espaços e classes sociais. In: GONÇALVES, Matia Flora; BRANDÃO, Carlos Antônio; GALVÃO, Antônio Carlos Filgueira (Org). Regiões e cidades, cidades nas regiões: o desafio urbano-regional. São Paulo: Editora Unesp, 2003.

OLIVEIRA, Francisco. Crítica à razão dualista. O Ornitorrinco. São Paulo: Boitempo, 2011.

OLIVEIRA. Floriano José Godinho de. Reestruturação produtiva e regionalização da economia no território fluminense. Rio de Janeiro: Garamond, 2008.

OLIVEIRA, Thabata Fonseca de. Os conjuntos habitacionais dos Institutos de Aposentadoria e Pensões (1941-1969) e a produção do espaço urbano do subúrbio da Leopoldina - cidade do Rio de Janeiro. Dissertação de Mestrado (Geografia) - Instituto de Geociências, Universidade Federal Fluminense, Niterói, 2013.

PADILHA, Valquíria. Shopping Center: a catedral das mercadorias e do lazer reificado. Tese de Doutorado (Sociologia) - Instituto de Filosofia e Ciências Humanas, Universidade Estadual de Campinas, Campinas, 2003.

PADUA, Rafael Faleiros. La Plaine Saint-Denis no movimento de reestruturação da região parisiense, Confins [online], v. 23, n. 23, mar. 2015.

PALMEIRA, Moacir. Prefácio. In: LOPES, José Sérgio Leite. O vapor do diabo: o trabalho dos operários do açúcar. Rio de Janeiro: Paz e Terra, 1978.

PEREIRA, Paulo César Xavier. Reestruturação Imobiliária em São Paulo (SP): especificidade e tendência. In: Pereira, Paulo César Xavier; et al 
(Org). Dinâmica imobiliária e reestruturação urbana na América Latina. Santa Cruz do Sul: Edunisc, 2006.

- Reestruturação Imobiliária em São Paulo (SP): especificidade e tendência. In: Anais do $\mathbf{X}$ Encontro de Geógrafos da América Latina, São Paulo, 2005.

Agentes imobiliários e reestruturação: interesses e conflitos na construção da cidade contemporânea. In: Pereira, Paulo Cesar Xavier (Org). Negócios imobiliários e transformações sócio-territoriais em cidades da America Latina. São Paulo: FAUUSP, p. 23-31, 2011.

Reestruturação imobiliária e produção do espaço metropolitano: nega o urbano e a urbanização tradicional. In: FERREIRA, Alvaro; RUA, João; MATTOS, Regina Célia. (Org). Desafios da Metropolização do Espaço. Rio de Janeiro: Consequência, 2015.

PINTO, Geraldo Augusto. A organização do trabalho no século XX: taylorismo, fordismo e toyotismo. São Paulo: Expressão Popular, 2013.

RODRIGUES, Juciano. Mobilidade urbana: uma questão metropolitana. Folha de São Paulo, 21 set. 2012. Disponível em: < https://politica.estadao.com.br/noticias/geral,mobilidade-urbana-umaquestao-metropolitana,934012>. Acesso em: 17 set. 2018.

ROLNIK, Raquel; FRÚGOLI, Heitor. Reestruturação urbana da metrópole paulista: a zona leste como território de rupturas e permanências. In: Cadernos Metrópoles, São Paulo, v. 6, p. 43-66, 2001.

ROSA, Daniel Pereira. De cidades-dormitório à centralidade da grande cidade periférica: trabalho, consumo e vida de relações de São Gonçalo na Região Metropolitana do Rio de Janeiro (RJ). Tese de Doutorado (Geografia Humana) - Faculdade de Filosofia, Letras e Ciências Humanas, Universidade de São Paulo, São Paulo, 2018.

SANTOS, Milton. A totalidade do diabo: como as formas geográficas difundem o capital e mudam as estruturas sociais. In: SANTOS, Milton Economia espacial: críticas e alternativas. 2 ed. São Paulo: EDUSP, 2007, p.187-204.

SCHMID, Christian. A teoria da produção do espaço de Henri Lefebvre: em direção a uma dialética tridimensional, Geousp, São Paulo, n. 32, p.89$109,2012$. 
SCOTT, Allen; AGNEW, John; SOJA, Edward; STORPER, Michael. Cidadesregiões globais. Espaço \& Debates, São Paulo, n. 41, p. 11-25, 2001.

SEABRA, Odette. Urbanização e fragmentação: cotidiano e vida de bairro na metamorfose da cidade em metrópole, a partir das transformações do bairro do Limão. Tese de Livre Docência (Geografia Humana) - Faculdade de Filosofia, Letras e Ciências Humanas, Universidade de São Paulo, São Paulo, 2003.

SILVA, Oséias Teixeira. O ponto de ruptura: reestruturação espacial na região metropolitana do Rio de Janeiro. Tese de Doutorado (Geografia Humana) - Faculdade de Filosofia, Letras e Ciências Humanas, Universidade de São Paulo, São Paulo, 2016.

SMITH, Neil. Reestruturação, reescalonamento e a questão urbana. Geousp, São Paulo, n. 33, p. 198-220, 2013.

SOARES, Maria Therezinha de Segadas. Nova Iguaçu: absorção de uma célula urbana pelo Grande Rio de Janeiro. Revista Brasileira de Geografia, Rio de Janeiro: IBGE, v. 24, n. 2, abr./jun. p. 3-104, 1962.

SOBRAL, Bruno Leonardo Barth. A falácia da "inflexão econômica positiva": algumas características da desindustrialização fluminense e do "vazio produtivo" em sua periferia metropolitana. Cadernos do Desenvolvimento Fluminense, Rio de Janeiro, n. 1, fev. 2013.

- Crise e ciclo: limites à capacidade de um crescimento econômico sustentado na periferia metropolitana do Rio de Janeiro diante do ciclo recente de grandes investimentos. Brasília/Rio de Janeiro: IPEA, 2015a. (Texto para Discussão 2143).

. O necessário, o possível e o impossível: uma leitura do papel das políticas públicas diante dos limites à coordenação de grandes investimentos na periferia metropolitana fluminense. Brasília/Rio de Janeiro: IPEA, 2015b. (Texto para Discussão 2154).

SOJA, Edward W. Geografias pós-modernas. A reafirmação do espaço na teoria social crítica. Rio de Janeiro: Jorge Zahar Editor, 1993.

SOULIGNAC, Françoise. La banlieue parisienne : cent cinquante ans de transformations. Paris: La Documentation Française, 1993. 
SOUZA, Marcelo Lopes de. O desafio metropolitano: um estudo sobre a problemática sócio-espacial nas metrópoles brasileiras. Rio de Janeiro: Bertrand, 2005.

- Rio de Janeiro: causas e perspectivas da crise. Revista Princípios. [online]. São Paulo: Editora Anita Guaribaldi, 2018. Disponível em: <http://revistaprincipios.com.br/artigos/32/cat/1825/rio-de-janeirocausas-e-perspectivas-da-crise-.html>. Acesso em: 06/03/2018.

SPOSITO, Maria Encarnação Beltrão. A produção do espaço urbano: escalas, diferenças e desigualdades socioespaciais. In: CARLOS, Ana Fani Alessandri; SOUZA, Marcelo Lopes; SPOSITO, Maria Encarnação Beltrão. (Org). A Produção do Espaço Urbano: agentes e processos, escalas e desafios. São Paulo: Contexto, 2011.

- Metropolização do espaço: cidades médias, lógicas econômicas e consumo. In: FERREIRA, Alvaro; RUA, João; MATTOS, Regina Célia. (Org). Desafios da Metropolização do Espaço. Rio de Janeiro: Consequência, 2015.

STEINBERG, Jean. La périurbanisation en France (1998-2002). GeoINova, no 7, p. 75-86, 2006.

SUBRA, Philippe. Le Grand Paris. Paris: Armand Colin, 2009.

TANAKA, Giselle Megumi Martino. Periferia: conceito, práticas e discursos: práticas sociais e processos urbanos na metrópole de São Paulo. Dissertação de Mestrado (Habitat) - Faculdade de Arquitetura e Urbanismo, Universidade de São Paulo, São Paulo, 2006.

TRINDADE JUNIOR, Saint-Clair. A cidade dispersa: os novos espaços de assentamentos em Belém e a reestruturação metropolitana. Tese de Doutorado (Geografia Humana) - Faculdade de Filosofia, Letras e Ciências Humanas, Universidade de São Paulo, São Paulo, 1998.

VALLADARES, Licia; PRETECEILLE, Edmund (Org). Reestruturação urbana: tendências e desafios. São Paulo: Nobel, 1990.

VASCONCELOS, Pedro de Almeida; CORRÊA, Roberto Lobato; PINTAUDI, Silvana Maria (Org). A cidade contemporânea: segregação socioespacial. São Paulo: Contexto, 2013.

VIANA, Juliana Nazare Luquez. Evolução e estruturação urbanas de São Gonçalo: do final do século XIX à segunda Guerra Mundial. 
Dissertação de Mestrado (Geografia) - Instituto Geociências, Universidade Federal Fluminense, Niterói, 2013.

VIEILLARD-BARON, Hervé. Les banlieues. Paris: Éditions Flammarion, 1997.

. Banlieues et périphéries. Des singularités françaises aux réalités mondiales. Paris: Hachette Supérieur, 2011 a.

La Plaine Saint-Denis : un ancien territoire industriel au centre des contradictions métropolitaines. In: Bulletin de I'Association de Géographes Français, 88e année, 2011b.

WOLLMANN, Luciana. Quando o apito não tocou: experiência operária e identidade de classe em um bairro operário em declínio (Barreto Niterói). Mediações, Londrina, v. 16, n.1, p. 177-200, jan./jun. 2011. 
Este Apêndice apresenta um breve relato da experiência de pesquisa na França e como os caminhos desta contribuíram para desenvolver um ponto de vista à problematização da realidade urbana. Para tanto, essa etapa da pesquisa contou com um vasto levantamento bibliográfico temático acerca dos estudos urbanos desenvolvidos em Paris e adjacências e uma sistematização do arcabouço conceitual utilizado para descrever os processos socioespaciais evidenciados.

O cadastramento em bibliotecas da Université de Paris e demais bibliotecas públicas, como a Bibliothèque Nationale de France, a Bibliothèque Centre Pompidou e as Bibliothèques Municipales de la Ville de Paris, para a consulta ao acervo disponível foi fundamental para o primeiro levantamento bibliográfico necessário para o desenvolvimento da pesquisa e sistematização. Como aponta Harvey na introdução do seu livro Paris, capital da modernidade, "é necessário um grande esforço para reunir os inúmeros estudos realizados a partir de diferentes perspectivas em uma síntese dinâmica" (HARVEY, 2015, p. 36). Dessa forma, foi possível estabelecer 8 (oito) eixos temáticos ao levantamento bibliográfico e considerar os acervos de 9 (nove) bibliotecas para a realização da pesquisa bibliográfica e documental, conforme o quadro 4 : 
Quadro 4 - Eixos temáticos e acervos consultados em Paris e adjacências

\begin{tabular}{|c|c|}
\hline $\begin{array}{c}\text { Eixos temáticos do levantamento } \\
\text { bibliográfico }\end{array}$ & Acervo consultado \\
\hline $\begin{array}{c}\text { Sobre os conceitos da análise } \\
\text { socioespacial sob os efeitos dos } \\
\text { processos de metropolização e } \\
\text { periurbanização }\end{array}$ & \multirow{3}{*}{$\begin{array}{l}\text { Bibliothèque Interuniversitaire Sorbonne } \\
\text { Bibliothèque Sorbonne Géographie } \\
\text { Bibliothèque Université Paris Dauphine } \\
\text { Bibliothèque Université Paris Saint-Denis } \\
\text { Bibliothèque Universitaire Paris Ouest - } \\
\text { Nanterre } \\
\text { Bibliothèque Paris Sorbonne Serpente } \\
\text { (Maison de la Recherche) }\end{array}$} \\
\hline Estudos urbanos e regionais & \\
\hline (Île de France et Le Grand Paris) & \\
\hline \multirow{4}{*}{$\begin{array}{c}\text { História urbana e da cidade de Paris: as } \\
\text { banlieues e o processo de urbanização } \\
\text { em Paris }\end{array}$} & \multirow{4}{*}{$\begin{array}{l}\text { Bibliothèque Nationale de France } \\
\text { Bibliothèque Centre Pompidou } \\
\text { Bibliothèques Municipales de la Ville de } \\
\text { Paris } \\
\text { Bibliothèque Université Paris Saint-Denis } \\
\text { Bibliothèque Universitaire Paris Ouest - } \\
\text { Nanterre } \\
\text { Bibliothèque Paris Sorbonne Serpente } \\
\text { (Maison de la Recherche) } \\
\text { Maison de Banlieue et de l'Architecture }\end{array}$} \\
\hline & \\
\hline & \\
\hline & \\
\hline $\begin{array}{l}\text { Urbanização e urbanismo na Île de } \\
\text { France }\end{array}$ & \multirow{4}{*}{$\begin{array}{l}\text { Institut d'aménagement et d'urbanisme de } \\
\text { la Région d'île-de-France (IAU - IdF) } \\
\text { Bibliothèque Université Paris Saint-Denis } \\
\text { Bibliothèque Universitaire Paris Ouest - } \\
\text { Nanterre } \\
\text { Bibliothèque Sorbonne Géographie }\end{array}$} \\
\hline $\begin{array}{l}\text { Panorama socioespacial da Île de } \\
\text { France e Le Grand Paris }\end{array}$ & \\
\hline $\begin{array}{l}\text { Projetos de renovação urbana e } \\
\text { reestruturação espacial }\end{array}$ & \\
\hline $\begin{array}{l}\text { Requalificação urbana nas áreas de } \\
\text { friches industrielles do norte de Paris }\end{array}$ & \\
\hline $\begin{array}{l}\text { Produção acadêmica na França sobre a } \\
\text { América Latina e as diferentes } \\
\text { perspectivas da análise socioespacial }\end{array}$ & $\begin{array}{l}\text { Bibliothèque Pierre Monbeig (Université de } \\
\text { Paris Nouvelle Sorbonne III) }\end{array}$ \\
\hline
\end{tabular}

Elaboração: Juliana Luquez

A participação, por exemplo, nos seminários de pesquisa Haussmann et la nouvelle modernité urbaine e Repenser le droit à la ville depuis les villes du Sud ${ }^{118}$, contribuíram profundamente para auxiliar no cumprimento do escopo dessa etapa da pesquisa, o qual repousou sobre a

118 Tiveram lugar, respectivamente, na École des Hautes Etudes em Sciences Sociales (de abril a junho de 2017) e na Université Paris Diderot (junho de 2017). 
discussão teórica e a revisão do léxico conceitual acerca dos termos utilizados para revelar as complexidades das dinâmicas socioespaciais de caráter metropolitano.

No caso do primeiro foi considerado como dado relevante a aproximação e a imediata apreensão da importância que a noção de produção do espaço tem para o desenvolvimento da pesquisa e, especialmente, na dimensão do espaço concebido - concepção teórica elaborada e apresentada por Henri Lefebvre, no livro La production de l'espace. Neste, o autor assevera que

As representações do espaço, isto é, o espaço projetado, o dos cientistas, planejadores, urbanistas, tecnocratas "cortadores" e "montadores", alguns artistas próximos ao científico, identificando o vivido e o percebido no projetado (o que perpetua as especulações aprendidas sobre os números: o número de ouro, os módulos e "cânones") É o espaço dominante em uma sociedade (um modo de produção). As concepções de espaço tenderiam (com algumas reservas sobre as quais seria necessário retornar) a um sistema de signos verbais, assim elaborado intelectualmente. (LEFEBVRE, 2000, p. 48) $)^{119}$.

O seminário Haussmann et la nouvelle modernité urbaine buscou apresentar e discutir as dimensões da urbanização hausmmaniana a partir da análise crítica dos planos e projetos de intervenção urbana, atrelados à uma concepção muito mais política do que técnica. As questões que se incorporaram à problemática da pesquisa foram: como discutir as transformações socioespaciais em Paris partindo da fase moderna e chegando à fase atual da metropolização, uma vez que os desafios são cada vez, e sempre, políticos - muito mais do que técnicos? E ainda: a dimensão política do projeto de Haussmann contribuiu para a extensão de

\footnotetext{
119 Texto original: «Les représentations de l'espace, c'est-à-dire l'espace conçu, celui des savants, des planificateurs, des urbanistes, des technocrates « découpeurs 》 et «agenceurs », de certains artistes proches de la scientificité, identifiant le vécu et le perçu au conçu (ce que perpétuent les savantes spéculations sur les Nombres: le nombre d'or, les modules et « canons ») C'est l'espace dominant dans une société (un mode de production). Les conceptions de l'espace tendraient (avec quelques réserves sur lesquelles il faudra revenir) vers un système de signes verbaux donc élaborés intellectuellement. »(LEFEBVRE, 2000, p. 48)
} 
Paris em seus subúrbios, considerando o constante movimento de destruição/construção?

David Harvey, nos dá duas pistas sobre como considerar Paris na sua relação com suas aglomerações urbanas próximas e também longínquas: a) "o imperador [Louis Napoleon III] tinha pouco interesse na distribuição de água corrente ou na incorporação dos faubourgs ${ }^{[120]}$, mas Haussmann era apaixonado por ambos - e conseguiu o que quis." (HARVEY, 2015, p. 22) e b) "essa questão de como enxergar a cidade e como representá-la durante fases de intensa mudança é um desafio intimidante" (HARVEY, 2015, p. 34). Em busca de argumentos teóricos às questões levantadas, consideramos que a produção do espaço se dá em combinação com sucessivas fases de estruturação/reestruturação e que este movimento produz espacialidades e temporalidades de uma totalidade.

Em consonância, o seminário Repenser le droit à la ville depuis les villes du Sud contribuiu ao viés metodológico, não só pela aproximação com o pensamento sobre o espaço e o urbano de Henri Lefebvre, mas também pelo fato de ter trazido à luz um léxico conceitual composto dos seguintes termos: droit à la ville, gentrification, planification de l'espace, appropriation et réappropriation de l'espace, homogénéisation, nouvelles pratiques quotidiennes. Considerando, sobretudo, a noção de direito à cidade proposta por Lefebvre, ao problematizarmos os processos de gentrification e planification de l'espace questionamos a legitimidade das lógicas de apropriação do espaço urbano, pois esses processos se realizam sob o controle de classes hegemônicas e seus anseios econômicos e políticos.

Ao inserirmos também na discussão o conceito de reestruturação, propomos a seguinte reflexão: o processo de reestruturação pode ser considerado um álibi à reprodução do capital, pois o espaço tem sido

120 Subúrbios imediatamente próximos aos limites da cidade de Paris, atualmente incorporados administrativamente à Paris. 
estruturado e restruturado a favor da homogeneização e da racionalidade capitalista. Pois, tal processo, enquanto característico de dinâmicas socioespaciais, é também possibilidade de "contra-homogeneização" se, ao romper com as lógicas do modo de produção, produzir espaços de vanguarda à legítima apropriação espacial: a reestruturação como possibilidade no devir.

Vimos a oportunidade de aprofundarmos essa problemática em outros espaços de debate, tais como o Colloque Internacional: Droit à la ville au Sud, expériences citadines et rationalités de gouvernement; os seminários La ville dans l'action politique: um demi-siècle d'expériences e Le défi métropolitain au Brésil et em France: regards croisés, e nos colóquios do Laboratoire Espace, nature et culture (ENEC). Neste último, apresentamos uma fala intitulada Regards croisés - les agglomérations urbaines parisienne et fluminense : un point de vue de la problématisation de la réalité urbaine contemporaine. Nessa oportunidade, reforçamos que - caráter de nossa análise era relacional e não comparativo e que manifestava-se muito mais pela problemática do espaço inaugurada nas últimas décadas do que por quaisquer semelhanças que o processo de urbanização pudesse guardar em termos de transformações socioespaciais na França e no Brasil - mais a frente trataremos, especificamente, dessa abordagem.

No livro Les mots de la Géographie: dictionnaire critique (1997), os autores apresentam um léxico conceitual da geografia francesa e os termos banlieue, périphérie e périurbain são apresentados como importantes marcos conceituais para a compreensão da estruturação do espaço urbano da região parisiense ponderando diversas temporalidades e dinâmicas socioespaciais. Ao tratarem do termo périurbain, por exemplo, os autores apontam que "o termo é frequentemente sinônimo de subúrbios $^{121 "}$ (BRUNET, R. et al., 1997, p. 379); entretanto é necessário

121 Texto original: «le terme est souvent synonyme de banlieues. » (BRUNET, R. et al., 1997, p. 379) 
considerar os novos conteúdos da atual dinâmica socioespacial para podermos diferenciá-los.

O trabalho de Berger (2004), busca justamente abordar esses novos conteúdos que permitem a construção de um conceito que englobe as áreas para além das banlieues do passado industrial e de uma composição social operária e migrante. Segundo a autora, "les périurbains de Paris", constituem a

Produção de novas áreas de residências e atividades, mas também transformações radicais dos bairros a partir dos quais as famílias candidatas deixam para assentamentos periurbanos: não podemos ignorar o papel desempenhado pela periurbanização de uma parte das camadas médias ou mesmo modestas na "guetização" de grandes complexos habitacionais ou na aceleração da "gentrificação" da capital e de algumas comunas suburbanas ${ }^{122}$. (BERGER, 2004, p. 10).

Aprofundar a discussão acerca das escolhas conceituais dos pesquisadores dos estudos urbanos na França nos aproximou também de suas abordagens metodológicas. A análise do léxico conceitual para a compreensão das transformações socioespaciais não se constitui apenas de um levantamento bibliográfico temático, mas também de um diálogo crítico sobre teoria e método de pesquisa: o aprofundamento teórico e a abordagem metodológica permitem uma visão mais ampla das complexidades metropolitanas contidas no objeto das pesquisas desenvolvidas no campo da geografia urbana e regional.

Dessa forma, por meio de reuniões de pesquisa, buscamos discutir diferentes possibilidades de interpretação da realidade a partir das complexidades e dinâmicas socioespaciais. Esse recurso, nos conduziu por um caminho interdisciplinar e interinstitucional, atentando-nos para a

122 Texto original : «Production de nouvelles zones de résidences et d'activités, mais aussi transformations radicales des quartiers d'où sont partis les ménages candidats aux implantations périurbaines : on ne peut ignorer le rôle qu'a joué la périurbanisation d'une partie des couches moyennes voire modestes dans la « ghettoïsation » des grands ensembles d'habitat ou dans l'accélération de la « gentrification » de la capitale et de certaines communes de banlieue. » (BERGER, 2004, p. 10). 
riqueza da produção do conhecimento sobre a cidade e o urbano na atualidade. Nos colocou em contato com produções acadêmicas relevantes e, sob a orientação do Professor Paul Claval, elencamos alguns pesquisadores para realização de reuniões de pesquisa, conforme detalha o quadro 5. 
Quadro 5 - Reuniões de pesquisa realizadas na França

\begin{tabular}{|c|c|c|c|}
\hline Reunião com: & Formação e contribuição & Data e local & Objetivos \\
\hline $\begin{array}{l}\text { Jean François } \\
\text { ROBERT }\end{array}$ & $\begin{array}{l}\text { Professor da Universidade de Paris-Sorbonne, secretário da Seção } \\
\text { "Prospectiva e Planejamento" do Conselho Econômico, Social e Ambiental } \\
\text { da Região Ile-de-France e dirigente de pesquisas. }\end{array}$ & 20/04, Paris & $\begin{array}{l}\text { - Apresentar o tema da pesquisa; } \\
\text { - Discutir os limites e possibilidades das análises comparativa } \\
\text { e relacional na análise geográfica considerando a realidade } \\
\text { socioespacial francesa e brasileira. }\end{array}$ \\
\hline & & 19/05, Paris & $\begin{array}{l}\text { - Discutir o processo de metropolização, as escalas e as } \\
\text { dimensões analíticas do conceito de periurbanização. }\end{array}$ \\
\hline Xavier DESJARDINS & $\begin{array}{l}\text { Professor de Planejamento Urbano, UFR de Geografia e Planejamento, } \\
\text { Chefe do Mestrado na área de Planejamento Urbano e Desenvolvimento } \\
\text { da Universidade Paris-Sorbonne. Membro da Unidade Conjunta de } \\
\text { Investigação "Espaço, Natureza e Cultura" }\end{array}$ & 05/05, Paris & $\begin{array}{l}\text { - Apresentar o tema de pesquisa; } \\
\text { - Discutir sobre os conceitos de análise socioespacial e os } \\
\text { efeitos da periurbanização no Grand Paris }\end{array}$ \\
\hline Jacques-LÉVY & $\begin{array}{l}\text { Professor de geografia e urbanismo no Instituto Federal de Tecnologia de } \\
\text { Lausanne, Suiça. Ele dirige o Laboratório Chôros e o Programa de } \\
\text { Doutorado em Arquitetura e Ciência da Cidade. Seus principais interesses } \\
\text { são a teoria do espaço das sociedades, particularmente através da } \\
\text { geografia política, cidades e urbanidade, globalização. }\end{array}$ & 07/07, Paris & $\begin{array}{l}\text { - Apresentar o tema de pesquisa; } \\
\text { - Discutir os princípios interpretativos da análise geográfica } \\
\text { para a compreensão da produção do espaço. }\end{array}$ \\
\hline Martine BERGER & $\begin{array}{l}\text { Geógrafa, é professora emérita da Universidade Paris-Pantheon Sorbonne. } \\
\text { A sua investigação centra-se nos estudos de áreas periurbanas da Île-de- } \\
\text { France, em particular nas mobilidades residenciais e diárias das famílias } \\
\text { na grande região parisiense. }\end{array}$ & 05/10, Paris. & $\begin{array}{l}\text { - Apresentar o tema de pesquisa; } \\
\text { - Discutir sobre os conceitos de sua análise socioespacial e os } \\
\text { efeitos da periurbanização na Île de France. }\end{array}$ \\
\hline Cécile GINTRAC & $\begin{array}{l}\text { Doutora em Geografia pela Universidade Paris Ouest-Nanterre, com a tese } \\
\text { intitulada: "No limiar crítico da cidade: três grupos de geografia } \\
\text { engajada". Completou um estágio de pesquisa no Laboratório de } \\
\text { Geografia Urbana da Universidade de São Paulo. É co-autora do livro } \\
\text { "Cidades contestadas. Por uma geografia crítica do urbano". }\end{array}$ & $14 / 11$, Saint-Denis & $\begin{array}{l}\text { - Apresentar o tema de pesquisa; } \\
\text { - Discutir, a partir dos resultados de sua pesquisa, os limites e } \\
\text { possibilidades de um pensamento universalista sobre a cidade } \\
\text { e urbano no início do século XXI. }\end{array}$ \\
\hline
\end{tabular}

Elaboração : Juliana Luquez 
Nas reuniões de orientação e de pesquisa realizadas nos foram apresentadas as contribuições do Institut d'aménagement et d'urbanisme de la Région d'île-de-France (IAU - IdF) e sua importância para a compreensão das atuais transformações urbanas $e$ intervenções urbanísticas no território da Île de France. O IAU, desde 2014, destaca sua atuação considerando o lema "os espaços precisam de ideias"123. Conhecer os planos urbanísticos das áreas de aglomeração urbana de Paris, especialmente, a Plaine Commne Saint-Denis e analisar os dossiês elaborados a partir dos ideais de planejamento territorial e planificação urbana, considerando as desestruturações e reestruturações estratégicas na produção do espaço, foram propósitos relevantes pois as "ideias no espaço", requerem também "ideias sobre o espaço", ou seja, pensar sobre o espaço e conceituar o espaço.

Vale destacar que o conceito ao qual perseguimos com mais atenção, o conceito de reestruturação, é também apresentado no acervo de publicações do IAU-ÎdF como recurso administrativo às implementações das estratégias econômicas do Estado e das empresas, além de estar atrelado às políticas de desenvolvimento urbano - cabe, pois, investigação e esclarecimento acerca dos usos e dos sentidos do conceito de reestruturação no léxico conceitual da literatura francesa sobre os estudos urbanos nos moldes como o fizemos no capítulo anterior para a literatura brasileira; todavia, esse constitui-se um desdobramento futuro.

Conhecemos também a Maison de banlieue et de l'architecture, situada na commune Athis-Mons. Trata-se de um centro de interpretação do meio ambiente urbano, do patrimônio e arquitetura dos subúrbios do território administrativo de Essonne, localizado na grande couronne da aglomeração parisiense. Por meio de exposições, publicações, eventos culturais e manutenção de um acervo documental especializado, "a

123 Texeto original «les espaces ont besoin d'idées», conforme: <https://www.iauidf.fr/linstitut/qui-sommes-nous/une-fondation-dutilite-publique.html>. Acesso em 30/05/2017. 
associação dá as chaves para entender melhor a fabricação e transformação de um território suburbano de Paris". ${ }^{124}$ A Maison de Banlieue et de l'Architecture nos ofereceu, através do seu acervo documental especializado, material técnico e acadêmico para ampliar nosso levantamento bibliográfico sobre a conformação e as transformações no espaço suburbano e periférico da aglomeração urbana de Paris, dentre os quais destacamos as publicações do Projeto Banlieues 89, atlas e anuários estatísticos oficiais sobre o movimento de destruição/construção que caracteriza a urbanização de Paris e sua região.

As visitas técnicas que realizamos nessas duas instituições nos foram úteis para aprofundarmos a perspectiva tridimensional da produção do espaço proposta por Lefebvre (SCHIMD, 2012), a saber: prática espacial, representação do espaço e espaço de representação. Quando observamos a realidade vemos que os conceitos que buscam apreendê-la apresentam limites. Por ser um exercício do pensamento sobre o real, o conceito não pode conter toda a riqueza do real; mas pode refletir aspectos essenciais de fenômenos ou processos analisados (LENCIONI, 2008b). Por esse motivo, realizamos trabalhos de campo de acordo com as demandas da própria investigação teórica. Pois ao tratar das transformações socioespaciais em Paris e na sua aglomeração urbana, fomos levados não só a uma análise dos usos e sentidos dos conceitos utilizados na compreensão dessa realidade como também à uma investigação empírica das complexidades abarcadas pelo léxico conceitual construído.

Na área I. La Plaine Commune, destacam-se as cidades de SaintDenis, Saint-Ouen e Aubervilliers. A primeira parte do trabalho de campo nessa extensa área foi realizado na cidade de Saint-Denis. A partir dos trabalhos de Albecker $(2014 ; 2015)$ os conceitos de banlieue, gentrification, désindustrialisation, friche industrielle e restructurations

124 Texto original « I'association donne des clés pour mieux comprendre la fabrication et la transformation d'un territoire de banlieue parisienne », conforme: <https://www.maisondebanlieue.fr/>. Acesso em 30/09/2017. 
foram considerados para a realização da atividade de campo. Todos esses conceitos foram utilizados pela pesquisadora para descrever e analisar a realidade urbana das cidades que compõem a aglomeração urbana mais imediata à Paris (première couronne de banlieue parisienne).

A maior contribuição teórica e empírica proporcionada pela observação e apreensão do real foi o fato de que, embora com características específicas de cada lugar, verificou-se o movimento da realização da urbanização em diferentes escalas e dimensões espaciais. Não adotamos o método de comparação na seção aqui apresentada, como já enfatizamos outras vezes, mas a análise relacional possível a partir dos conceitos utilizados para explicar os processos socioespaciais em curso na França e no Brasil, nos permitiu um quadro analítico singular: as transformações socioespaciais na cidade de Saint-Denis, situada ao norte de Paris, na antiga e tradicional região industrial.

A cidade de Saint-Denis (Île de France, França) tem sido analisada, por exemplo, a partir dos conceitos de banlieue, gentrification, désindustrialisation, friche industrielle, restructurations, mixité-sociale, requalification urbaine, por diversos pesquisadores de temas e estudos urbanos (imagem 36). A análise que apresentamos anteriormente sobre a cidade de São Gonçalo (Rio de Janeiro, Brasil) apropriando-nos de conceitos como, subúrbio industrial, periferização, espoliação urbana, desindustrialização, segregação, reestruturação do espaço, nos permitiram uma concepção relacional do espaço-tempo da urbanização como fenômeno universal dando ênfase a importância da periodização na análise das transformações socioespacial de cada formação econômicosocial.

Na segunda parte do trabalho de campo nessa localidade, buscamos conhecer algumas áreas da banlieue proche que se destacam pelas ações e operações de renouvellement urbaine ou rénovation urbaine, marcadas pelas demolições de parte dos bairros em uma espécie de variação do processo de gentrification des banlieues (imagem 37). Uma importante 
contribuição foi a de Padua (2015) que descreve essa região perseguindo o seu "movimento de reestruturação". De acordo com o autor

\begin{abstract}
Nas últimas décadas a periferia parisiense é foco de inúmeros projetos que buscam, através da reestruturação do espaço, propor alternativas para combater o grande desemprego gerado pela saída massiva de indústrias, atraindo novas atividades econômicas que incorporem, ao menos em tese, os trabalhadores sem trabalho após a queda do emprego industrial. Um exemplo mais profundo e atual é o projeto do governo francês chamado "Grand Paris", que se apresenta como um grande plano de "aménagement du territoire" [ordenamento territorial] da região parisiense, enfocado sobretudo em ações de reestruturação da periferia de Paris. (PADUA, 2015, p. 5)
\end{abstract}

Imagem 36 - Saint-Denis: ao fundo, antiga chaminé de fábrica, um novo edifício e, em primeiro plano, a sinalização que indica o Estádio da França, construção símbolo da mais recente fase de reestruturação do espaço na aglomeração urbana de Paris.

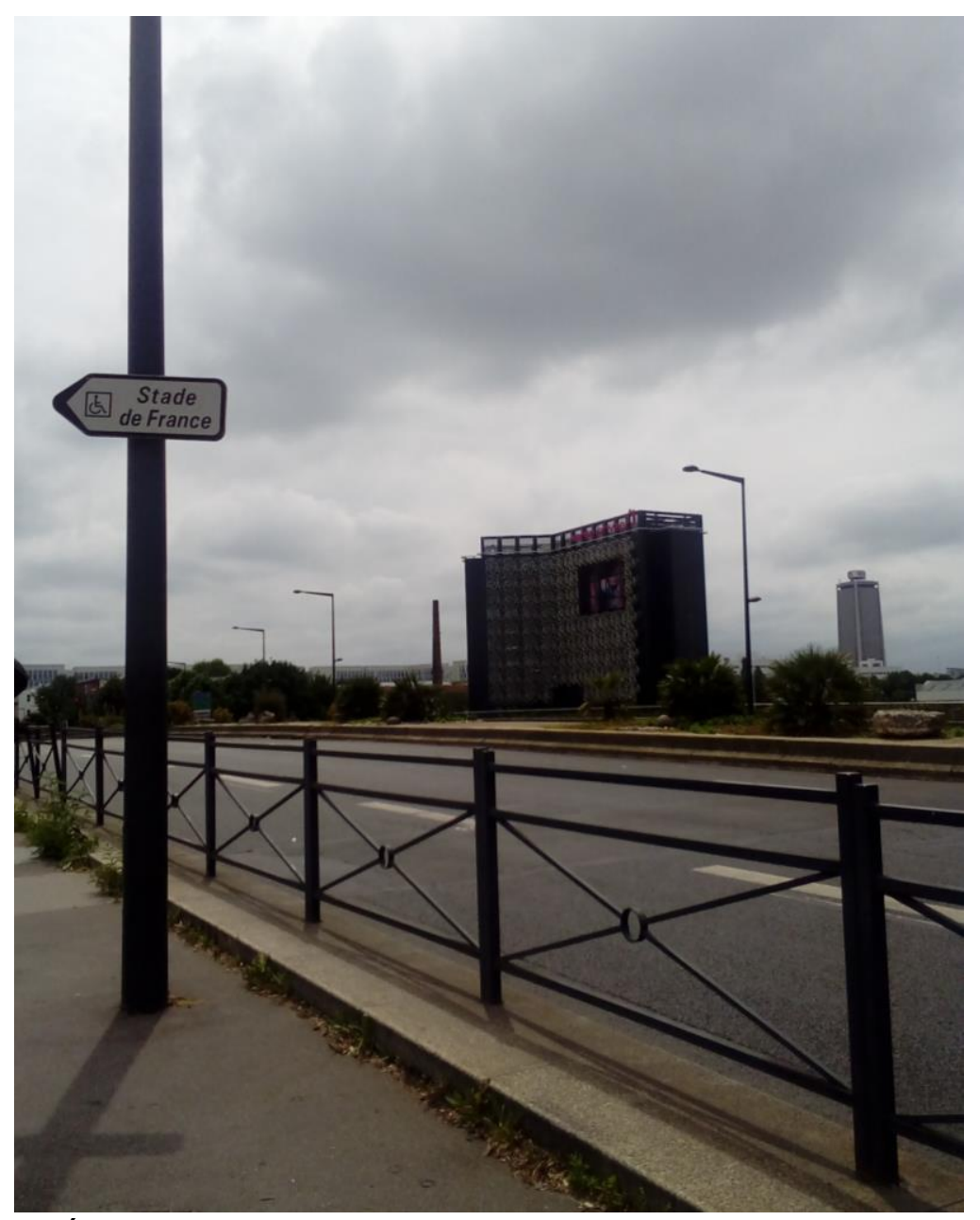

Crédito: Juliana Luquez 
Imagem 37 - Saint-Denis: futura instalação da Gare Grand Paris Express

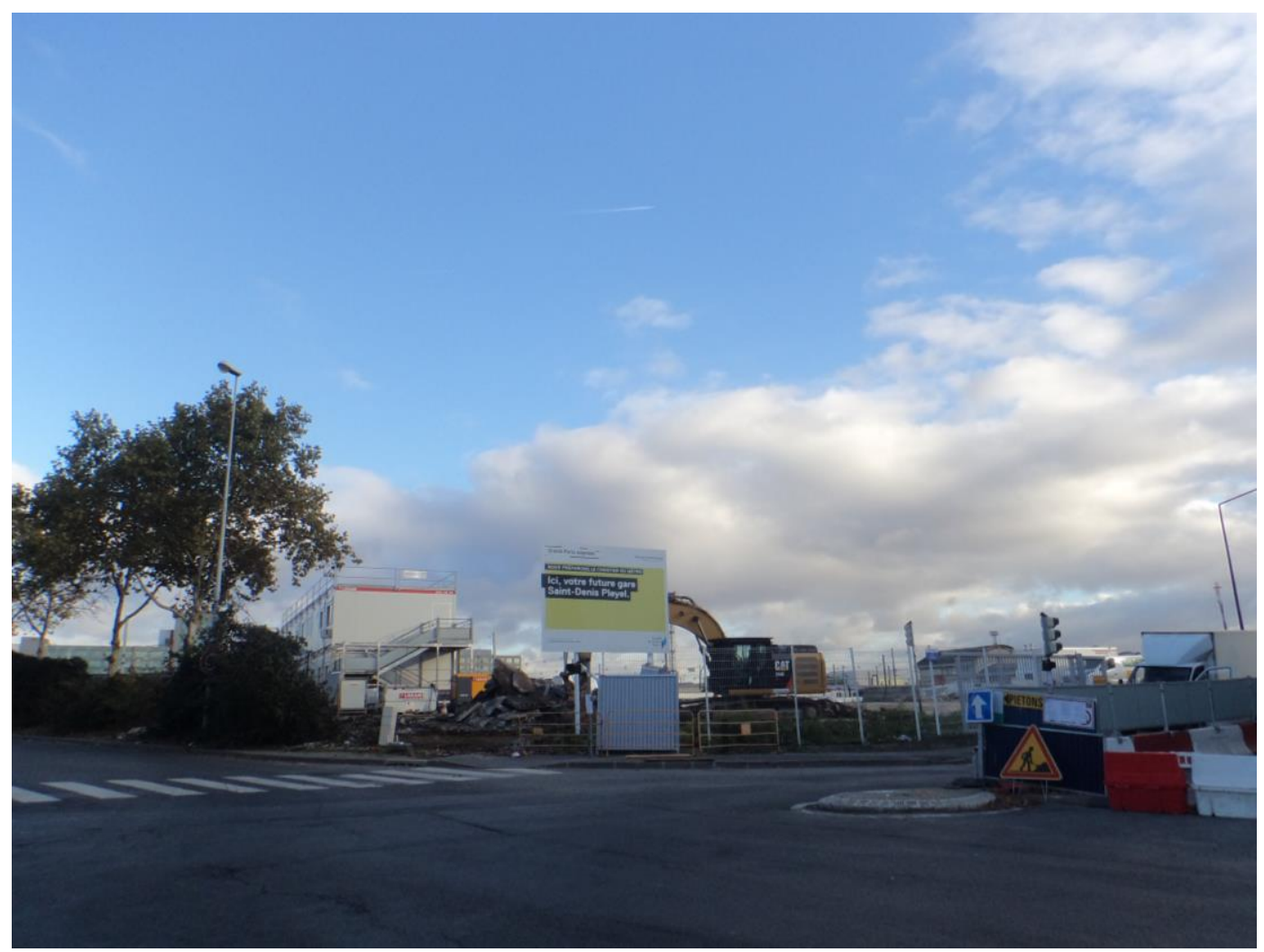

Crédito: Juliana Luquez

Padua também considera em sua abordagem uma importante ruptura perceptível tanto na dimensão teórica quanto prática da análise socioespacial. O autor sugere que

Primeiramente podemos dizer que há uma passagem da problemática industrial para uma problemática urbana, na reflexão sobre a urbanização contemporânea e para a compreensão da realidade atual; em segundo lugar podemos dizer que há uma dimensão de mundialidade nos processos observados, seja pela crise urbana que manifesta e que é observada em outras partes do mundo (é muito evidente em São Paulo, por exemplo) e como o Estado (seja ele governado por partidos de direita ou de esquerda), articulado aos setores privados, busca, em diferentes lugares do mundo, a mesma saída para a resolução das crises de acumulação, que é a produção de determinado tipo de espaço, voltado para o consumo produtivo. Nesse sentido, os exemplos que poderíamos citar de Paris seriam muito parecidos aos que podemos observar em São Paulo, apesar das imensas particularidades que cada metrópole apresenta. (PADUA, 2015, p. 11) 
As áreas II. Zone Industrielle Nord e III. Clichy-Batignolles foram visitadas e observadas ponderando a discussão teórica em torno das renovações e operações urbanas - como conceito e como estratégia de desenvolvimento urbano utilizados pelos agentes de produção do espaço que marcam a intensa transição, nas relações sociais de produção e na paisagem urbana, das atividades produtivas às quais função, forma e estrutura urbana entram em desequilíbrio após uma fase de consolidação (imagem 38).

Imagem 38 - Clichy-Batignolles: área de planejamento combinada

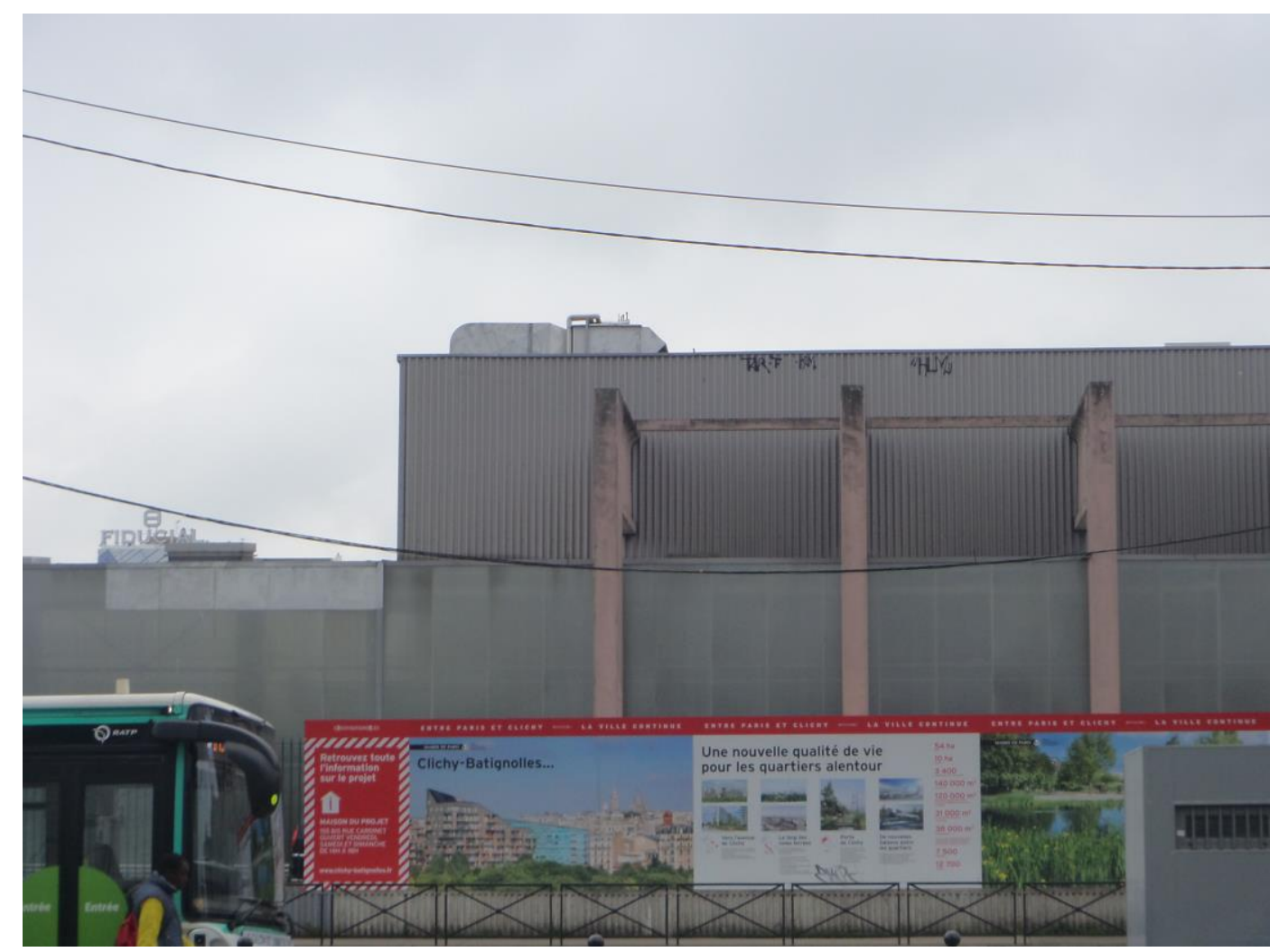

Crédito: Juliana Luquez

O campo na área IV. La Petit Ceinture de Paris teve como propósito compreender a expansão territorial e os limites administrativos da cidade de Paris, atentando-nos para a incorporação dos faubourgs e a construção da rede de comunicação ferroviária do Centro às áreas periféricas. Destacamos os conceitos de estruturação urbana e champ urbain (CLAVAL, 1981). O conceito de champ urbain pode ser compreendido desde a formação da Paris intramuros, sua dinâmica de expansão e a 
atual reestruturação espacial das cidades que são limítrofes à Paris. Pois, em cada ponto, onde há acesso a uma certa vantagem tirada de toda a aglomeração e das características locais, isso constitui-se um champ urbain.

O conceito de champ urbain busca revelar a cidade na relação com suas externalidades, considerando as atuais questões quanto à localização de empreendimentos imobiliários e a natureza cada vez mais corporativa das políticas de desenvolvimento urbano. Assim, a teoria de champ urbain apresenta-se ainda com forte potencial explicativo para a análise das transformações socioespaciais no espaço urbano parisiense. Ademais, o próprio termo champ urbain possui uma dimensão conceitual complexa. Pois vários dos conceitos presentes no léxico conceitual das análises socioespaciais contribuem para ampliar a compreensão teórica e empírica de um champ urbain.

O quadro 6 apresenta todos os roteiros que foram realizados para aprofundar empiricamente as noções conceituais e abordagens analíticas com o objetivo de problematizar a realidade urbana contemporânea e a compreensão da produção do espaço, seja em uma perspectiva do urbanismo de Estado, seja nas apropriações privadas e no desenvolvimento de formas neoliberais de atuação de classes econômicas dominantes. A questão que se coloca repousa no fato que rupturas e continuidades marcam o movimento de realização da urbanização e imprimem características no espaço e no tempo que, uma vez periodizados, podem também revelar a simultaneidade do fenômeno urbano.

Tal periodização cumpre, outrossim, um papel de confrontação com as continuidades que coexistem em cada estruturação/reestruturação necessária à produção do espaço de reprodução do modo de produção vigente. Essas continuidades são, em verdade, a diversidade e a coexistência de tempos e espaços historicamente produzidos. 
I. La Plaine Commune

Saint-Denis ${ }^{125}$

Antiga cidade real, Saint-Denis, é uma das mais importantes cidades da banlieue parisiense (sua basílica abriga túmulos dos reis da França). Durante o processo de industrialização na França, Saint-Denis, destacou-se não só pela implantação de indústrias, como também pela organização social do trabalho e da vida cotidiana dos operários, sendo administrada pelo Partido Comunista. Sua composição populacional e, hoje, extraordinariamente de imigrantes africanos e arabes. A construção do Stade de France na área limítrofe com a cidade de Paris, inaugurado em 1998, retomou e agravou o debate sobre segregação socioespacial, agentes produtores do espaço e reestruturação espacial no domínio do urbano.

b. La rénovation urbaine dans la banlieue

O movimento de demolição-reconstrução possui uma representação política que nos permite compreender as lógicas socioeconômicas que operam nas dinâmicas espaciais e revelam propósitos e interesses dos agentes públicos e privados enquanto promotores imobiliários. Compreender esse movimento na aglomeração urbana de Paris requer um retorno às exigências da elite tecnocrata que fundaram, ainda sob o modelo hausmmanianna de produzir a cidade, os grandes projetos de renovação urbana na França, bem como a inserção dos espaços especialmente) da banlieue de Paris no contexto de transformação da cidade e do espaço.
No bojo dos projetos e políticas de planejamento territorial e planificação urbana da virada do sécul XX pora características específicas o XXI, a regiao industrial do norte de Paris, apresenta determinacão do capital industrial para o financeiro na produção do espaço. zona industrial possui uma composicão urbana que nos permite mergucho. Esta processo de reestruturação atentos as possibilidades de periodizações da análise: a região, que desde 0 início do século $X X$, abrigou indústrias metalúrgicas siderúrgicas e uma significativa população operária, tornou-se um friche industrielle e viveu as consequências da crise instaurada pelo processo de

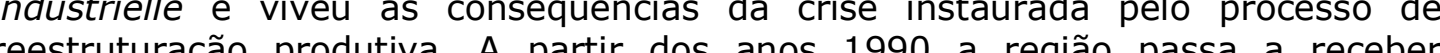
empreendimentos imobiliários de diversas naturezas (comercial, logística industrial-inovadora), vinculados à projetos de desenvolvimento territoria

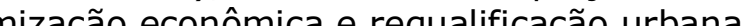

Compreender a política de renovação urbana buscando cuas nuances nos processos de especulação, gentrificação, segregação e reestruturação.
Sarcelles (Gare de Sarcelles Saint-Brice) Lochères

Garges les Gonesse

Stains

Métro Saint-Denis Université

\section{Zone Industrielle Nord}

Station Saint-Denis - Porte de Paris (Métro 12) Canal Saint-Denis

Stade de France

Avenue du Président Wilson e Autoroute du Nord

Musée de l'art e d'histoire de Saint-Denis

Basilique Cathédral de Saint-Denis

Université de Paris VIII

De la place du Front populaire jusqu'aux quartiers à l'ouest

Conhecer os empreendimentos das políticas territoriais de (ZAC)

Analisar as dinâmicas socioespaciais considerando transição da determinação do capital industrial para o Panceiro na produção do espaço na região ao norte de Paris
Métro Liérge (M13)

Gabriel Péri - Gare Bus 177 (Zone Industrialle Nord)

Bongarde - Centre Commercial Régional Qwartz (ZAC), Villeneuve-la-Garenne

La Litte - Ancienne friche industrialle (ZAE)

Mairie de Saint-Ouen

La Plaine - Stade de France (RER B)

Usines Centers Paris Nord 2

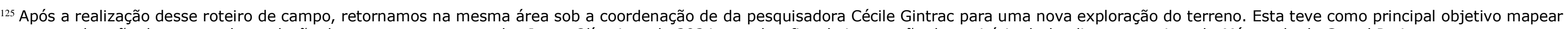
os pontos de ação dos atores da produção do espaço no contexto dos Jogos Olímpicos de 2024 e os desafios de integração do território da banlieue ao projeto do Métropole du Grand Paris. 


\section{Clichy-Batignolles}

Clichy é uma cidade situada ao norte de Paris que pertence ao departamento de Hauts de Seine na administração regional da Île de France e ao território Boucle Nord de Seine, no Grand Paris. A cidade apresenta significativos marcos no tempo e no espaço no contexto das tranformações urbanas de Paris e sua aglomeração urbana, podemos exemplicar considerando a intervenção urbanística para implantação do Parc Martin Luther King e a instalação do moderníssimo complexo que sediará o Nouveaux Palais de Justice de Paris às portas de Clichy. Este complexo insere-se como principal projeto da zone d'aménagement concerté (ZAC) Clichy-Batignolles.
Observar e analisar a conurbação (ou tisser en lien) entre Paris e Clichy, considerando o limite em diagonal com Boulevard Périphérique;

Observar e apreender as tranformações urbanas no contexto da nouvelle modernité: entre les bâtiments historiques et le nouveau Palais de Justice;

Examinar o modelo de urbanismo de Haussmann produção do espaço urbano das banlieues rouges e através das questões da cidade contemporânea.
Gare Pont Cardinet - Chemin de fer Square des Batignolles - Extensions de Paris Entrée e traverser du Parc Martin Luther King Paysages du parc - Thèmes et usages Palais de Justice - Porte de Clichy (Pôle des transports en commun)

Clichy-la-Garenne - au-delá du Périphérique

\section{Le Petit Ceinture de Paris}

La petite ceinture é originalmente uma infraestrutura de transporte, a primeira inha férrea que ligava as diferentes redes nacionais entre si; mais também, a primeira linha de desvio usada por viajantes para conectarem-se aos vários subúrbios (imedlatos) de Paris. Inaugurada entre os anos de 1852 a 1869 interrompida ao trons Paris, na sua parte oeste, está hoje, implantada parte do trecho da Réseau Express Régional C (RER C), entre l'avenue Henri-Martin (Paris) à Porte de Clichy.

\section{Express Regionalc (RER C), entrelavenue Henri-Martin (Pans) a Porte de Clichy.}

Os espaços da periurbanização na aglomeração urbana de Paris permitem-nos compreender a reestruturação do espaço a partir das demandas habitacionais $e_{\text {, }}$ consequentemente, das demandas de consumo do espaço por meio da mobilidade e estratificação sociais. Considerando alguns eixos da região pariense, a partir dos quais o processo de periurbanização moldou suas formas e resignificou o espaço, visitamos 6 localidades que possuem as caracteristicas mais marcantes desse processo no contexto da metropolização franciliana ${ }^{126}$
Observar e analisar o processo de estruturação e expansão urbanas de Paris a partir do contorno de todo o seu "cinturão";

Acessar as entradas das demais aglomerações urbanas que historicamente se estruturaram, desde os antigos muros até o atual Boulevard Périphérique

\section{Les périurbains parisiens}

Observar e analisar o processo de periurbanização na Île de France, a partir de Paris, considerando os eixos da rede de trens de grande extensão (RER e Trasilien);

Compreender os novos conteúdos da produção do espaço metropolitano parisiense em sua dimensão territorial social.

\section{Les Grands Ensembles}

No período do pós-guerra, as políticas sociais de habitação e planificação urbana No periodo do pós-guerra, as políticas sociais de habitação e planificação urbana
que produziram as paisagens e amalgamaram os conteúdos da banlieue proche e compreendidos a partir das formas urbanas resultantes desse contexto: les grands ensembles. Os conjuntos habitacionais, característicos da estrutura urbano-industrial, constituem uma representação importante para a compreensão das transformações antigas e recentes no espaço parisiense.
Compreender os conteúdos da produção do espaço metropolitano parisiense em sua dimensão territorial social.
Départ : Porte de la Villette (Paris $19^{\text {ème}}$ ) Porte Dorée (Paris $12^{\text {ème}}$ )

Porte de Vanves (Paris 14 ${ }^{\text {ème}}$ )

Porte Maillot (Paris $16^{\text {ème }}$ )

Arrivée : Porte de la Villette (Paris $19^{\text {éme}}$ )
Mantes la Jolie

Rambouillet

Dourdan la Fôret

Melun/Fontenebleau

Provins

Meaux
Chêne-Pointu (Clichy-sous-Bois)

Cité des 4000 (La Cournouve)

Sarcelles

\footnotetext{
Referente à Reglão da Ile de france.
} 


\section{Les villes nouvelles : I'exemple d'Évry}

Évry é exemplo de ville nouvelle criada no contexto de modernização e descentralização urbanas da região parisiense que teve lugar nos idos dos anos 1960. A cidade materializou-se como instrumento de planificação urbana e elemento estruturante de desenvolvimento territorial. Se a implantação, o financiamento e os modelos urbanísticos estavam na pauta de sua estruturação, hoje, essa pauta considera as dinâmicas de recriação e requalificação des espaços públicos, reestruturação dos espaços intra-urbanos, etc. As villes nouvelles são formas urbanas complexas do ponto de vista técnico e operacional, bem como da compreensão de suas lógicas espaciais, uma vez que insere-se no constante movimento de construção/reestruturação do espaço.
Conhecer o projeto de implementação de villes nouvelles na região parisiense

Compreender a produção do espaço metropolitano no contexto de uma política de planejamento de regiñes contexto fortemente praticada entre as decadas de 1960 e 1980.

1 - Gare d'Evry-Courcouronnes : AREA - Bernard Hamburger arch. (1975); hall refait en 1989 et en 2009.

2 - Immeuble La Butte Creuse : Pierre Riboulet arch. (1984)

3 - Place de l'Agora : J. Le Couteur et G. Khalifa arch. (1975)

4 - Préfecture, Palais de Justice et Hôtel du Département : ATEA - G. Lagneau, M. Weill arch. $(1971,1975,1987)$

5 - Les Passages:

Passages Nord : Alexis Josic arch. (1979, pour la SCIC)

Passages universitaires : René. Dottelonde arch. (1979)

Passages Sud : Georges Maurios arch. (1981)

6 - Place des droits de I'homme : aménagement de Mme Gustavson (artiste), Hôtel de ville : Lévy, Muller, Poisay arch. (1991), Chambre de commerce : Phillppe \& Martine Deslandes arch. (1990), Cathedrale : Mario Botta arch. (1996)

7 et 8 - «Repenser un centre urbain 》: $140000 \mathrm{~m} 2$ Atelier PUZZLER (F. Brouillet et B. Dubus) architecteAtelier PUZZLER ( $F$.

9 - Un îlot : îlot RZ (355 logements), Archicubik - Carmen Santana architecte urbaniste (2011-2017)

10 - Un édifice : Résidence étudiante « Marguerite Yourcenar », Suzel Brout arch. (2011) - projet lauréat du Yourcenar », suzel Brout arch. (2011) projet lauréat du d'Ile de France)

11 - Une composition architecturale : Atelier Puzzler et Brénac \& Gonzalez arch. (2011-2014)

VIII. La Défense

Se considerarmos a teoria de champ urbain, teremos essa localidade como exemplo significativo da lógica da cidade e de sua produção. O crescimento da aglomeração urbana de Paris, a partir dos anos 1960, é marcado, especialmente, pelo fortalecimento das funçôes terciarias das atividades urbanas. Desse modo, o champ urbain se desenvolve a partir dos centros de negócios e decisão. No caso de Paris, essa tendênicia resultou na construção do quartier des affairres La Défense, situado entre Paris e territórios de sua banlieue proche (Puteaux, Courbevoie, Neuilly-sur-Seine, Nanterre e La Garenne-Colombes), reestruturando o espaço e as relações da cidade com sua periferia imediata.

Elaboração: Juliana Luquez

\section{Gare RER A - La Défense}

Place de La Défense - Église Notre Dame de Pentecote

Compreender os conteúdos da produção do espaço e suas

\section{dimensões territorial e financeira.}

Square Gallieni

Métro Esplanade La Défense 
ANEXO I - Questionário aplicado à população metropolitana na cidade de São Gonçalo, a partir do qual foram formulados os gráficos apresentados no Capítulo 1

\section{Perfil socioeconômico do(a) entrevistado(a)}

$\begin{array}{ll}\text { 1. Idade } \square \text { 2. Identidade de Gênero } & \text { 3. Local de residência }\end{array}$

4. Portador de necessidades especiais: ( ) SIM ( ) NÃO

5. Renda média: ( ) não tenho/desempregado （）Até $R \$ 1.000 \quad$ （） De $R \$ 1.000$ a $R \$ 2.000$

$\begin{array}{llll}\text { ( ) De } R \$ 2.000 \text { a } R \$ 3.000 & \text { ( ) De } R \$ 3.000 \text { a } R \$ 5.000 \quad \text { ( ) Acima de } R \$ 5.000\end{array}$

\section{Sobre você e a cidade}

6. No seu dia a dia, você se locomove:

( ) pela cidade que reside (intra-urbano)

( ) por mais de uma cidade (interurbano). Qual(is)?

7. Da lista abaixo, indique 3 (três) problemas que mais afetam sua vida na cidade?
( ) Habitação
( ) Emprego/oportunidade
( ) Saneamento básico
( ) Transporte/mobilidade
( ) Violência
( ) Poucos espaços públicos, de cultura e lazer

8. Da lista abaixo, indique 3 (três) opções que você considera mais urgente para a cidade?
( ) Metrô
( ) Shopping e centros empresariais
( ) Ciclovia
( ) Estacionamento
( ) Unidades de habitação popular
( ) Indústrias
( ) Condomínios fechados
( ) Teatro, cinema e galeria de arte

9. Como você percebe as transformações da cidade?

( ) Não há transformações

( ) A cidade se transforma lentamente

( ) A cidade se transforma rapidamente

( ) A cidade se transforma de tempos em tempos

10. Você considera que vivemos uma crise urbana?

( ) SIM ( ) NÂO

11. Se sim para a questão 10 , qual o caminho você considera mais viável para buscar soluções à essa crise?

( ) Organização da sociedade em grupos para pensar e definir as ações na cidade

( ) Políticas integradas com a participação de várias representações

( ) Políticas urbanas pensadas e executadas exclusivamente pelo Estado

( ) Políticas urbanas pensadas e executadas pelo Estado em parceria com empresas privadas 
ANEXO II - Roteiro de perguntas apresentado ao representante da Câmara Metropolitana do Rio de Janeiro, o qual não foi respondido

\section{Questões propostas}

1. De acordo com as publicações da Câmara Metropolitana (Caderno Metropolitano e Revista Rio Metrópole), adotou-se o termo metrópole para fazer referência a aglomeração urbana do Rio, ou seja, a metrópole Rio e sua região de influência institucionalizada. Qual foi o critério utilizado para a adoção desse termo? Como o conceito metrópole é concebido pelo Estado do Rio de Janeiro?

2. No mapa dos maiores fluxos interurbanos e metropolitanos do Brasil o destaque está na aglomeração urbana do Rio de Janeiro. A ligação Niterói/São Gonçalo já é, segundo dados do IBGE (2015), a segunda maior da rede urbana brasileira, e outras seis ligações compõem os fluxos mais intensos do País. Para alguns autores, a crise urbana que vivemos se deflagrou justamente pelo gatilho da mobilidade (ou melhor, da imobilidade). A Região Metropolitana do Rio de Janeiro parece ter herdado um "legado de impossibilidades" no que diz respeito a questão urbano-regional. Qual a perspectiva da Câmara Metropolitana diante do "nó" que se tornou a mobilidade urbana fluminense?

3. Pegando "um gancho" da questão anterior, sabemos que a falta de investimentos em políticas urbanas de caráter metropolitano, também afeta diretamente a maximização e otimização dos investimentos e serviços públicos ou privados previsto para o Rio de Janeiro. Os megaeventos esportivos sediados no Brasil e no Rio de Janeiro, não ultrapassaram fronteiras especulativas de valorização/revalorização do espaço-mercadoria. A impossibilidade de investimento em porções alternativas do território metropolitano fluminense também se deve, além de uma histórica luta política, pela falta de outros investimentos 
de longo prazo: a manutenção da malha ferroviária, a ampliação do serviço de metrô e barcas, o domínio das facções criminosos em territórios da periferia imediata, etc. A Olímpiada de 2024, terá como cidade-sede Paris, mas parte significativa da estrutura urbana necessária está prevista para ser desfrutada e construída na cidade de Saint-Denis, subúrbio metropolitano de Paris. No caso do Rio, nenhum investimento na "metrópole" (Rio e aglomeração metropolitana), apenas na "metrópole" (cidade do Rio de Janeiro). Esse breve panorama coloca a questão regional como um desafio à questão urbana no contexto metropolitano fluminense. Como superá-lo?

4. A Câmara Metropolitana de Integração Governamental é a primeira iniciativa do Estado do Rio de Janeiro desde a FUNDREM (1975-1989). Segundo dados primários coletados em nossa amostragem, realizada em São Gonçalo entre os meses de fevereiro e maio e que contou com 182 respondentes de diferentes localidades da RMRJ,

- $38 \%$ dos citadinos acreditam que as soluções à crise urbana no Rio de Janeiro podem ser encontradas por meio de políticas integradas com a participação de várias representações;

- 35\% acreditam na organização autônoma da sociedade para pensar e definir as ações na cidade;

- 19\% esperam por políticas públicas pensadas e executadas pelo Estado em parceria com empresas privadas;

- 8\% esperam por políticas públicas pensadas e executadas exclusivamente pelo Estado.

Esse resultado mostra que, diferentemente do que a grande mídia nos quer fazer pensar, a sociedade não só acredita em melhorias como também reconhece nas políticas públicas e na organização de si mesma um caminho para superar o "legado das impossibilidades". Como a Câmara Metropolitana vem atuando para incentivar e fomentar as diversas formas de ação coletiva e gestão participativa na região metropolitana do Rio? 
5. Considerando a mesma amostragem mencionada anteriormente, $93 \%$ dos citadinos declaram que vivem uma "crise urbana". Qual é a pauta da Câmara Metropolitana visto a necessária retomada da questão metropolitana no contexto da "crise do Rio"?

6. Em 2013, como pesquisadora do IPEA no projeto Rede IPEA, participei de um evento no qual um dos palestrantes anunciava "São Gonçalo como menina dos olhos do Governo do Estado do Rio de Janeiro". Isso porque a cidade seria o epicentro do eixo de reestruturação do espaço fluminense não só do ponto de vista da econômica do petróleo, mas, e especialmente, da economia metropolitana especulativa que gera renda fundiária. Esse movimento de valorização/desvalorização/revalorização amplia as demandas infraestruturais no processo de reprodução da metrópole. O senhor concorda com essa perspectiva do desenvolvimento regional fluminense, há um eixo no processo de reestruturação do espaço fluminense que aponta para São Gonçalo como polo dinamizador? Se sim, como o senhor descreveria esse processo que reestrutura 0 espaço gonçalense na passagem de sua realidade urbano-industrial para a realidade metropolitano-financeira?

7. A mancha metropolitana se expande e se consolida em uma contraditória relação do processo de urbanização fluminense: a concentração e a dispersão. Se por um lado a concentração reforça a dependência da região em relação a Metrópole Rio e o vazio produtivo de sua periferia (SOBRAL, 2011; 2013); por outro lado, a dispersão da aglomeração urbana reproduz o caos e torna mais intensos e cruéis os processos de segregação e fragmentação socioespaciais. Para o senhor, porque ainda não se superou esse paradigma concentração/dispersão na conformação e reconfiguração do espaço metropolitano fluminense? 
ANEXO III - Reportagem do Jornal O Globo-Extra, de 22 de setembro de 2014 (imagem 17).

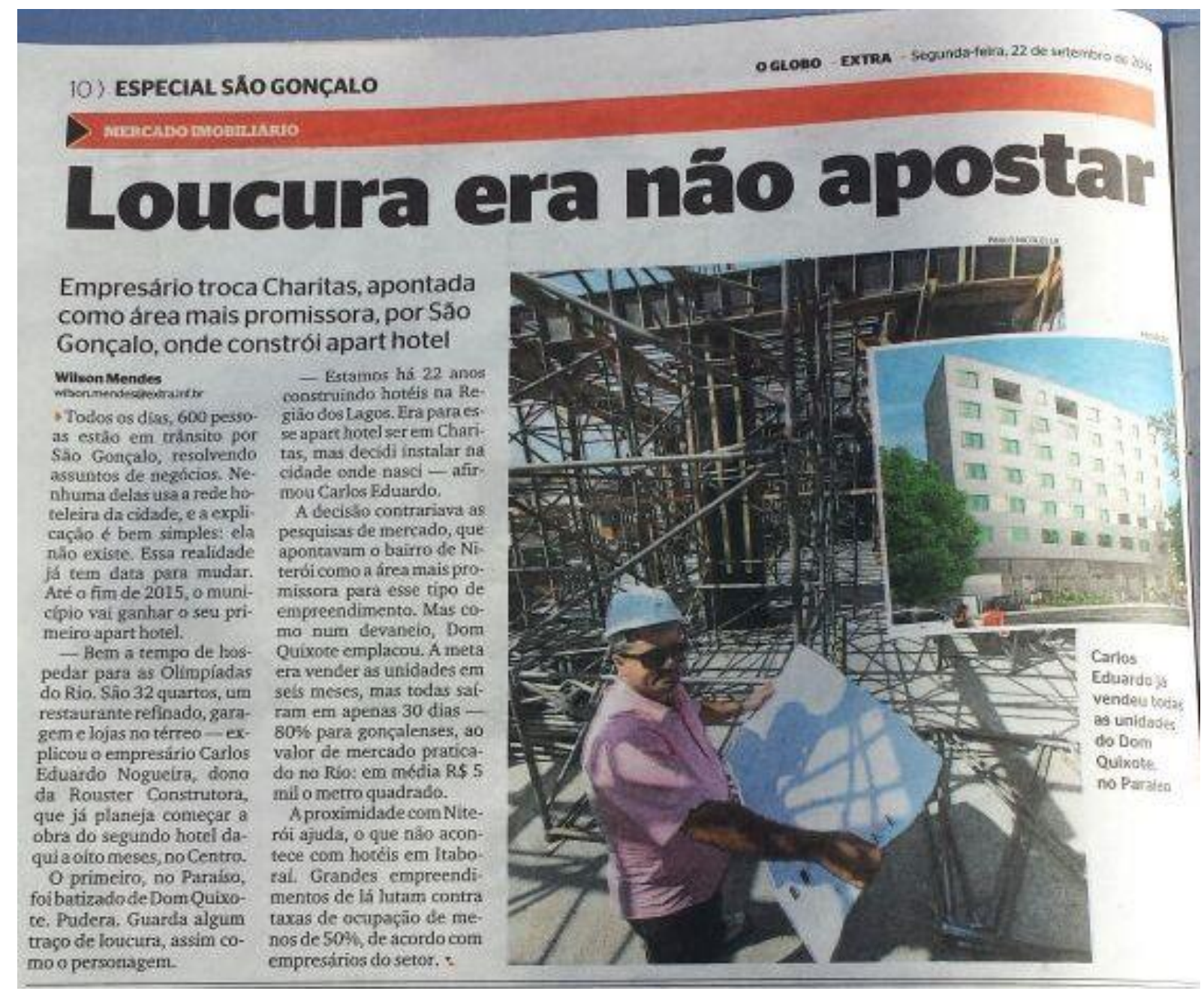

